(C) SOUTHERN CAUCASUS SCIENTIFIC JOURNALS

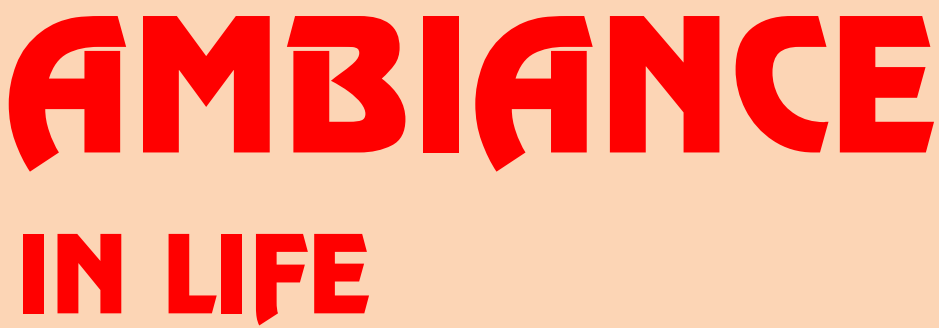

INTERNATIONAL SCIENTIFIC JOURNAL IN MEDICINE

JOURNAL OF BEHAVIORAL MEDICINE

REFEREED \& REVIEWED JOURNAL
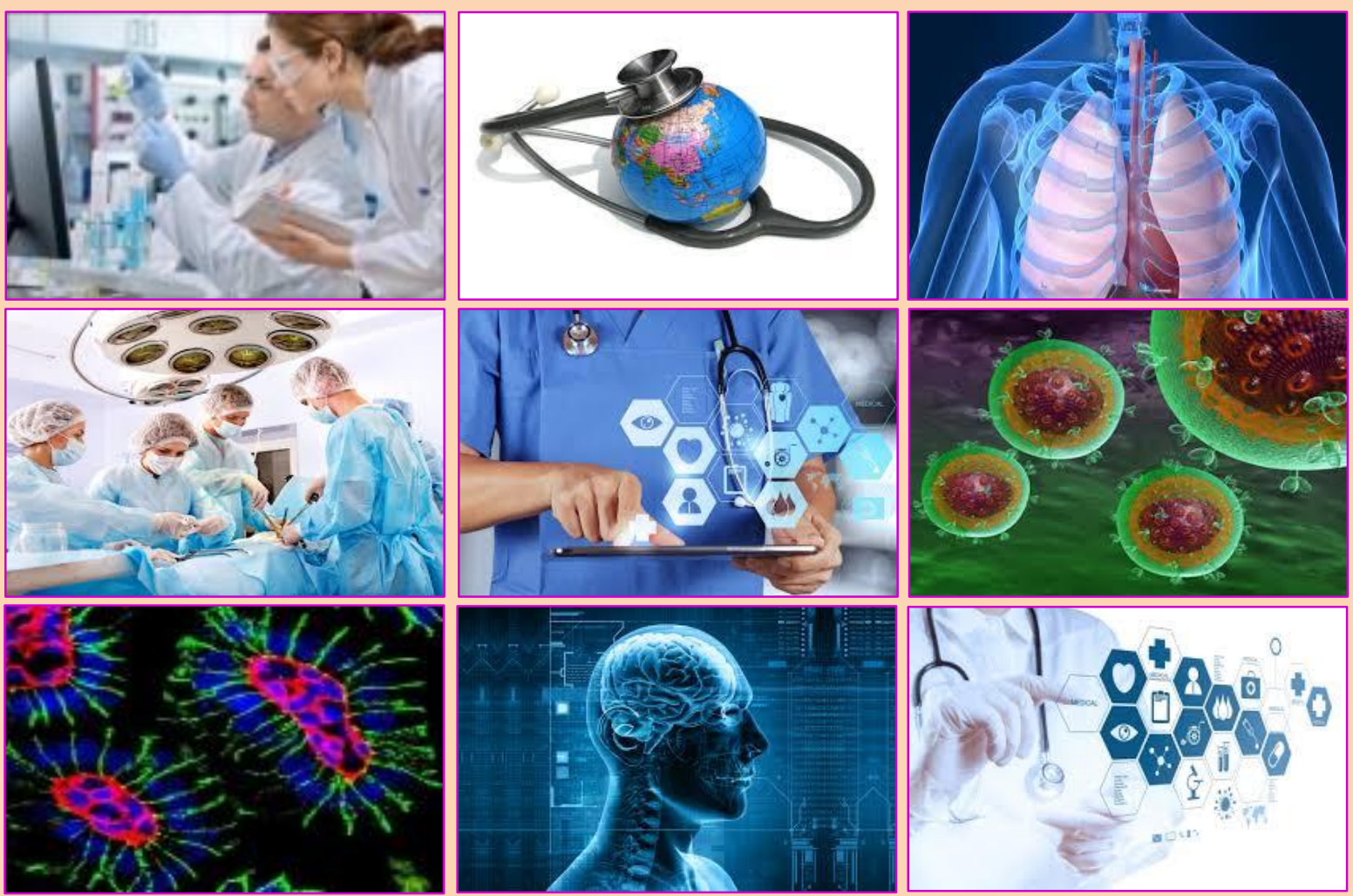
06.01.2021 ISSN: 2346-8068; E-ISSN: 2346-8181; DOI: 10.36962/ALISJMSC

(C) SOUTHERN CAUCASUS SCIENTIFIC JOURNALS

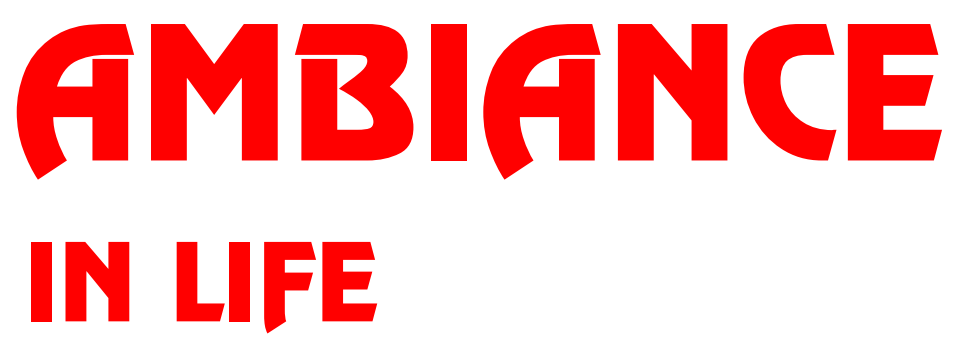

INTERNATIONAL SCIENTIFIC JOURNAL IN MEDICINE

JOURNAL OF BEHAVIORAL MEDICINE

REFEREED \& REVIEWED JOURNAL 
TABLE OF CONTENTS

Gulmira Zhurabekova, Merey Aliyeva

NEUROIMAGING DATA OF THE STUDY OF THE CHIASMAL-SELLAR REGION

STRUCTURES

Ketevan Lobzhanidze, Maia Sulaqvelidze, Revaz Tabukashvili

DYNAMICS OF PULMONARY FUNCTIONAL INDICES AT CHRONIC OBSTRUCTIVE

PULMONARY DISEASE

Айгуль Базарбаева, Азамат Кубиев, Дария Бекбатырова, Аяулым Нуртлеуова

ДИАГНОСТИЧЕСКИЕ ОСОБЕННОСТИ ЗЛОКАЧЕСТВЕННЫХ ОПУХОЛЕЙ ДЕТЕЙ

ПЕРВОГО ГОДА ЖИЗНИ

B.M. Zhumadullaev, Zh.G. Saduova, A.A. Uskenbayeva, G.A. Nurzhanova,

D.M. Yeginbergenova, A.M. Nazarova

PROGNOSTIC VALUE OF N-MYC GENE AMPLIFICATION IN PATIENTS WITH

NEUROBLASTOMA

Ляззат Манжуова, Айгуль Базарбаева, Наргиза Кахарова

ХАРАКТЕРИСТИКА ПАЦИЕНТОВ С ПЕРВИЧНЫМИ ИММУНОДЕФИЦИТНЫМИ

СОСТОЯНИЯМИ

Ляззат Манжуова

АНАЛИЗ ОРГАНИЗАЦИИ МЕДИЦИНСКОЙ ПОМОЩИ ДЕТЯМ С ГЕМОФИЛИЯМИ В

РЕСПУБЛИКЕ КАЗАХСТАН ....

Гаухар Нуржанова, Айгуль Базарбаева, Зухра Хашимова, Айгерим Ускенбаева

КЛИНИКО-ДИАГНОСТИЧЕСКИЕ ОСОБЕННОСТИ ДЕТЕЙ С ЛИМФОМОЙ

ХОДЖКИНА

Т.А. Адайбаев, М.К. Жаналиева, Р.Н. Жарилкасимов

МОРФОЛОГИЯ КИШЕЧНО-АССОЦИИРОВАННЫХ ЛИМФОИДНЫХ ОБРАЗОВАНИЙ

ТОНКОЙ КИШКИ БЕЛЫХ КРЫС В РАННЕМ ОНТОГЕНЕЗЕ

Куаныш Умбетов, Аяулым Нуртилеуова

ОПЫТ ПРОВЕДЕНИЯ ГАПЛОИДЕНТИЧНОЙ ТРАНСПЛАНТАЦИИ

ГЕМОПОЭТИЧЕСКИХ СТВОЛОВЫХ КЛЕТОК С ИСПОЛЬЗОВАНИЕМ ТЕХНОЛОГИИ

ИМУННОМАГНИТНОЙ СЕПАРАЦИИ ЛИМФОЦИТОВ

Umid Ibragimov, Sundetilla Sargelov, Murat Ensepbaev, Amankul Taynekova,

Malika Inragimova

COMPUTER TOMOGRAPHY AND X-RAY DIAGNOSTICS OF PERIPHERAL PRIMITIVE

NEUROEECTODERMAL TUMORS (PNET) IN CHILDREN .

Ahliman Amiraslanov, Elnur Ibragimov, Sevinj Abdiyeva, Samira Qaraisayeva

SECONDARY INFECTION IN CANCER PATIENTS OF THE MUSCULOSKELETAL

SYSTEM ....

Learta Alili Ademi, Dr.Spec.Blerim Ademi

ACUTE DISSEMINATED ENCEPHALOMYELITIS IN A 5 YEARS OLD BOY, A CASE

REPORT

Huseynova Lala, Huseynova Qumru

R761H M694I, M694V, V726A, R202Q, M680I AND E148Q MEFV GENE (FAMILIAL MEDITERRANEAN FEVER GENE) MUTATIONS IN THE AZERBAIJANIAN

PATIENTS 


\section{Simuzar Hajizade}

MEDICAL SUPPORT IN THE SAFETY SYSTEM OF NAVIGATION OF THE MODERN

CIVIL MARINE

Tamara Abaeva

MORPHOFUNCINAL CHARACTERISTIC OF THYMUS IN SEVEN MONTHLY RATS

UNDER CONDITIONS OF MOUNTAIN HYPOXIA OF KYRGYZSTAN .................... 54

Nino Pirtskhelani, Nino Kochiashvili, Ketevan Kartvelishvili, Levan Makhaldiani

INHERITED THROMBOPHILIA AND COVID-19

Lala Akhundova, Gulmira Alibayova, Nurmammad Mustafayev, Samira Rustamova,

Irada Huseynova

IMPACT OF ANGIOTENSIN-1 CONVERTING ENZYME GENE INSERTION/DELETION (I/D)

POLYMORPHISM ON DIABETES MELLITUS SUSCEPTIBILITY AMONG AZERBAIJAN

POPULATION

Zhanar Nurgaliyeva, Shahniza Abdraimova, Aliya Mahsutkhanova, Nozima Holmirzaeva,

Kamola Khanseitova, Saltanat Dzhantasova

OBESITY IN CHILDREN AS A FACTOR OF MYOCARDIAL REMODELING

Zhanar Nurgaliyeva, Araily Manasbaeva, Sakhipzhamal Sabirova, Saiyara Nadyrova,

Alfira Muratkhan, Zakhrokhon Ergashbaeva, Alfiya Zhanzak

THYROID STATUS IN CHILDREN WITH TYPE 1 DIABETES MELLITUS

Sain Safarova

ARTIFICIAL INTELLIGENCE ON THE IDENTIFICATION OF DIABETES-RELATED OSTEOMETABOLIC DISORDERS

Shynykul Zhanserik

A NOVEL PEPTIDE MODULATOR OF THE HUMAN CHANNEL NAv1.5 FROM

LATRODECTUS TREDECIMGUTTATUS SPIDER VENOM

Tamar Giorgadze, Sophio Giorgadze

CLINICAL ASPECTS OF PYROPTOSIS

Aynur Ansarova

PRIMARY PRODUCT OF PHYTOPLANKTON IN RESERVOIRS OF AZERBAIJAN AND

THE DESTRUCTION OF COMMON ORGANIC MATTER

Aysel Hashimova

THE ANTHROPOGENIC ADAPTATION INDEX OF REPTILES IN URBANIZED AREAS

OF THE ASHBERON PENINSULA

Zh. Oralkhan, G. Zhurabekova, S. Abzalieva

INFLUENCE OF PERIODONTAL TREATMENT ON PRETERM BIRTH: SYSTEMATIC

REVIEW AND META ANALYSIS

Anar Tulyaeva, Gulmira Zhurabekova, Erbol Bekmukhambetov, Erbolat Iztleuov, Aidana Tautanova

DOUBLE BREAKING OF DNA THREADS AND GASTRIC CANCER

Gulmira Zharmakhanova, Victoria Kononetc, Lyazzat Syrlybayeva, Eleonora Nurbaulina,

Lyazzat Baikadamova

HYPERPHENYLALANINEMIA: CASE REPORT

Nazigul Zhumagazhiyeva, Amir Kappassov

PROBLEM OF MEDICAL STUDENTS WHICH PREVENT FORMING A HEALTHY

LIFESTYLE 
ПРЕНАТАЛЬНАЯ ДИАГНОСТИКА ХРОМОСОМНЫХ БОЛЕЗНЕЙ У ПЛОДА

Bahram Zhumadullaev, Zhazira Saduova, Aigerim Uskenbayeva, Gauhar Nurzhanova, Dinara Yeginbergenova, Aru Nazarova

PROGNOSTIC VALUE OF N-MYC GENE AMPLIFICATION IN PATIENTS WITH

NEUROBLASTOMA

Райхан Майтбасова

НЕСПЕЦИФИЧЕСКИЙ АОРТОАРТЕРИИТ У ДЕТЕЙ: ПРОБЛЕМЫ ПОЗДНЕЙ

ДИАГНОСТИКИ И ЛЕЧЕНИЯ

Сергей Остроумов, Сергей Котелевцев, Евгений Криксунов

НЕКОТОРЫЕ РЕЗУЛЬТАТЫ УЧЕНЫХ МГУ И РАН ПО ВОПРОСАМ НАКОПЛЕНИЯ

ХИМИЧЕСКИХ ЭЛЕМЕНТОВ В ОРГАНИЗМАХ

Мария Галас, Алия Жайлаубаева, Бахрам Жумадуллаев, Айгуль Баязитовна, Ляззат

Манжуова, Риза Боранбаева

РЕЗУЛЬТАТЫ ТЕРАПИИ ПАЦИЕНТОВ С ДИАГНОЗОМ «НЕЙРОБЛАСТОМА»

СОГЛАСНО ПРОТОКОЛУ NB-2004

Анар Туляева, Гульмира Журабекова, Ербол Бекмухамбетов, Ерболат Изтлеуов, Айдана Таутанова

ДВОЙНЫЕ РАЗРЫВЫ НИТЕЙ ДНКА И РАК ЖЕЛУДКА 


\title{
NEUROIMAGING DATA OF THE STUDY OF THE CHIASMAL-SELLAR REGION STRUCTURES
}

\author{
${ }^{1}$ Gulmira Zhurabekova, ${ }^{2}$ Merey Aliyeva \\ ${ }^{1}$ Department of fundamental Medicine, Higher School of Medicine, Al- Farabi Kazakh National University, Kazakhstan \\ Email: gzhurabekova@gmail.com \\ ${ }^{2} \mathrm{PhD}$ student of $2^{\text {nd }}$ course, Department of normal and topographic anatomy with operative surgery, West Kazakhstan \\ Marat Ospanov Medical University, Kazakhstan. \\ Email: aliyevamerey7@gmail.com
}

Background: Sphenoid sinus (SS) is separated by a septum with various position, therefore sizes of two sinus cavities are variable [2]. In addition, sphenoid sinus differs in pneumatization type, ranging from its absence to extensive forms.Knowledge of the linear size and shape of the skull, the structure of the sphenoid sinus and its interconnection with nearby structures will help to avoid complications when performing surgical endoscopic interventions in the chiasmal-sellar region. Currently, the transsphenoid approach is the most optimal in neurosurgery for intracellar and cranial pathologies treatment. Due to proximity and anatomical interconnection of sphenoid sinus with other anatomical structures, such as anterior knees of intracavernous segments of internal carotid artery (ICA), optic nerve $(\mathrm{ON})$, there is a high risk of complications during surgery $[1,2,3,4]$.

Purpose: Features of skull craniometric parameters, the type sphenoid sinus pneumatization, and its practical value in various $\mathrm{ON}$ and ICA positions.

Methods: The retrospective research, using magnetic resonance imaging (MRI) scans of head, included 1111 people, with 410 males and 701 females out of them but the scope of the article is limited to 93 of them, including 34 males (37\%) and 59 females (63\%) aged from 20 to 71 years. The research design complies with the Helsinki Declaration's provisions and was approved by the Local Ethics Committee of the West Kazakhstan Medical University named after Marat Ospanov №50 from January 17, 2020. The average age of males was 41.6 ( 20 - 71 years), and for females was 41.7 (20 - 66 years). Inclusion criteria were as the following: 1) age range from 20 to 71 years, 2) patients living in Aktobe region, 3) patients sent for examination with pituitary (hypophysis) pathology, 5) patients referred with CSR vascular pathology, 6) patients referred for verification of CSR pathology diagnosis. Exclusion criteria were as the following: 1) patients with skull bones fractures, 2) patients after skull trepanation, 3) patients having orthodontic and orthognathic research at examination time, 4) patients with congenital skull malformations, having gross skull deformation, 5) patients with brain tumors and hemorrhages with obvious CSR compression at examination time, 6) pregnancy, lactation, long-term use of hormonal drugs by persons of both gender. With the RadiAnt Dicom Viewer 5.5.1 program measured craniological indices: crosslongitudinal skull index, degree of pneumatization of the sphenoidal sinus; protrusion and/or gaping of internal carotid artery canal and optic nerve.Allstatistical analyses were performed using Statistica 8.0.

Results: The data we obtained show that the vast majority of older males (60-80 years old) had mesocrane skull shape, in contrast to females, among whom the frequency of brachycrane skull shape prevails. Among 20-40 years aged males, the highest percentage falls on mesocrane skull form, while 
in females the frequencies of mesocrane and brachycrane skull forms are relatively the same. In males and females with ages of 40-60 years, mesocrane and brachycranean skull forms are almost half of the total number of cases. An interesting fact was that dolichocranous skull shape is absolutely not found in both males and females of 40-80 years old age. The skull structure distribution by gender. Based on the sphenoid sinus types classification by Ossama \& Guldner, our research revealed that there is no Conchal type (type I) in both genders. In 20-40 age, type III prevailed among males, while type IV has a maximum among females. Types III and IV predominated among males and females of 40-60 years old age. In 60-80 years category, type III prevails among females, while males have two times less. Type II is absent among 40-60 aged males and 60-80 aged females. As per the research of anatomical structures close to SS, it was found that ON and ICA canals form protrusions on the inner surface of the sphenoid sinus sidewall. The protrusion degree was ranged from a slight depression on the lateral wall to a complete "immersion" of canals into the sinus. No protrusion of ON and ICA canals were found in 60-80 years old males in $80 \%$ of cases, while complete absence of protrusion was shown in case of the same age females. However, protrusion of only the ICA canal occurs in $60 \%$ of cases with over 60 years old age females, while the same was in only $20 \%$ with the same age males. There was no case of ON canal protrusion in males, but ON canal gave a protrusion in sphenoid sinus wall in $49 \%$ of 20-40 years old females. ON and ICA canals protrusion in 20-60 years old males was found in about $30 \%$, and the same protrusion was found in 60-80 years old females in $40 \%$.

Conclusions: This study is aimed at identifying the features of structure of the sphenoidal sinus, focusing on the absence of a dolichocrane type of skull among the population, on the clear distinction between men and women by the type of skull structure and the features of pneumatization of the sphenoidal sinus. The presellar type of sphenoidal sinus has a virtually low adherence to changes in sinus canals in types II and IV. Thus, careful planning of trans-sphenoid access to the sella is possible with modern imaging methods. Different anatomical variations can be detected so that problems can be predicted to be assessable. In order to avoid morbid consequences during surgery, it is imperative that clinicians determine the location and extent of sphenoid sinus walls and its relation to adjacent vital structures whenever trans-sphenoid pituitary surgery is expected. The few surgical tips related to sphenoid sinus anatomical configuration are important to keep in mind during such an approach.

Keywords: MRI; sphenoid sinus; pneumatization; internal carotid artery; optic nerve

\section{REFERENCES}

1. Rahmati A, Ghafari R, AnjomShoa M. Normal Variations of Sphenoid Sinus and the Adjacent Structures Detected in Cone Beam Computed Tomography. J Dent (Shiraz). 2016;17(1):32-37.

2. Newman H, Milne N, Lewis SB. Neurosurgical Anatomy of the Internal Carotid Artery: Magnetic Resonance Imaging Study of the Sellar Region. World Neurosurg. 2020 Jan;133:e711-e715.

3. Labib MA, Prevedello DM, Carrau R, Kerr EE, Naudy C, Abou Al-Shaar H, Corsten M, Kassam A. A road map to the internal carotid artery in expanded endoscopic endonasal approaches to the ventral cranial base. Neurosurgery. 2014 Sep;10 Suppl 3:448-71; discussion 471. 
4. Stokovic N, Trkulja V, Dumic-Cule I, Cukovic-Bagic I, Lauc T, Vukicevic S, Grgurevic L. Sphenoid sinus types, dimensions and relationship with surrounding structures. Ann Anat 203:69-76. https://doi: 10.1016/j.aanat.2015.02.013 (2016). 


\title{
DYNAMICS OF PULMONARY FUNCTIONAL INDICES AT CHRONIC OBSTRUCTIVE PULMONARY DISEASE
}

\author{
Ketevan Lobzhanidze ${ }^{1}$, Maia Sulaqvelidze ${ }^{2}, \operatorname{Revaz}_{\text {Tabukashvili }}^{3}$ \\ ${ }^{1}$ Ketevan lobzhanidze- N. Kipshidze Central University Clinic, Tbilisi, Georgia, Primary Care Physician, Georgia. \\ Email: keti221@yahoo.com, \\ ${ }^{2}$ Maia Sulaqvelidze - N.Kipshidze Central University Clinic, Outpatient Department, Head of the Department. European \\ University, Professor, Georgia, Email: maiasulaq@gmail.com, \\ ${ }^{3}$ Rezo TabukaSvili - Tbilisi State Medical University, Department of Internal Medicine Propaedeutics, Head of the \\ Department, Professor. Georgia,
}

\section{ABSTRACT}

The goal of study was detailed analysis of dynamics of exacerbation of FEV-1, the factor closely associated with pulmonary functional status and disorder progress; as well as, we intended looking for FEV-1 dynamics correlation with other indices of pulmonary functional status, including forced vital capacity (FVC\%) of lung, Tiffeneau-Pinelli index (FEV1/FVC\%), rate of peak expiratory flow (FEF/PEF), expiratory flow capacity FVC between $25 \%$ and $75 \%$ of graph (FEF25\%, FEF50\%, FEF75\% ); we studied correlation between FEV1 dynamics and various gradation of Mmrc gradation of self-evaluation questionnaire - (Modified Medical Research Council Questionnaire). The study was done on the base of "Acad. N. Kipshidze Central University Clinic", LLC. 78 COPD patients were involved in the study, functional status of lungs was assessed by spirometry, clinical condition was assessed by modified questionnaire for dyspnea evaluation (mMRC - Modified Medical Research Council Questionnaire) given by medical council. Dynamics of FEV1 in the purpose of finding correlation between the gradations of dyspnea self-evaluation questionnaire and speciphic treatment (or if such does not exist) conducted in anamnesis study contingent was divided in three groups: the group \#1 - untreated patients $(\mathrm{n}=26)$; the group \#2 - patients taking salbutamol monotherapy $(n=28)$, the group \#3 - patients taking combined therapy $(n=24)$. In the result of study reliable correlation was revealed between such indices of FEV1 and pulmonary functional status as FVC, FEV1/FVC and FEF 50\% which indicates significant worsening of functional possibilities of peripheral airways and pulmonary vital capacity parallel to the progress of disease. In the result of study correlation between FEV-1 index and gradations of dyspnea self-evaluation questionnaire is statistically reliable in COPD patients which increases value of self-evaluation questionnaire. Thus, timely and adequate treatment of COPD is significant factor for desirable prognosis of disease. Wide implementation of spirometry is the most important factor for timely diagnostics of COPD in riskgroups which itself is very important for starting timely and adequate treatment and impeding progress of disease. Popularization of dyspnea self-evaluation questionnaire will significantly help to reveal COPD risk-groups in which severe and undesirable course of disease is anticipated.

Introduction

Chronic obstructive pulmonary disease (COPD) is a progressive disorder characterized with persistent, dense restriction of air flow and chronic inflammation developed in pulmonary airways in the response of dangerous particles and/or gasses, which as a rule is compliable to treatment and prevention. Chronic inflammation of pulmonary airways is associated with progressive worsening of pulmonary functional status and characterized with various degree dyspnea and episodes of 
exacerbations. [1][5]. The disorder progresses for several years and associated lethality is due to either disorder itself or complications associated with it. In future decade more spread of COPD is anticipated as it is related to pollution of environment and generally increased life expectancy of the population [5]. COPD is the third leading cause of lethality worldwide [4] [9], its urgency is related to widespread of the disorder either in developing or developed countries which is the significant challenge in treatment and prevention of the disorder in the field of healthcare [3][10]. By the data of World Health Organization it is recognized as one of the reasons of morbidity, mortality and global challenge of health care in modern universe [15][8]. According to evaluation of pulmonary function one of the most important factors determining severity of the disorder is forced expiratory volume in a second - FEV1 (Forced expiratory volume [11] (after taking bronchodilator FEV1 < 80\% of estimated value and FEV1/FVC $<0,70$ confirms existance of airflow restriction which is not completely reversible) [5]. Decrease of FEV1 is estimated as an unreliable prognostic index for COPD which is associated, on the one hand, with frequency of disorder exacerbation and, on the other hand, increased risk of death [7][17][16]. Despite the importance of the problem looking for and identification of the factors which reliably correlate with the dynamics of decrease in FEV1 is still the field of challenge. As well as, data existing in literature concerning this issue is quite different which itself rises questions on possible reasons of variability [6].

Main goal of COPD management is decrease in symptoms, prevention of exacerbations and generally interruption of disorder progress. As well as, considering global spread of disorder, the goal of any scientific research is development of COPD management strategy which helps in interruption of disorder progress by prevention of disorder risk-factors and its exacerbations.

The main objective

Purpose of the study was detailed analysis of dynamics of exacerbation of FEV-1, the factor closely associated with pulmonary functional status and disorder progress; as well as, we intended to find FEV-1 dynamics correlation with other indices of pulmonary functional status, including forced vital capacity (FVC\%) of lung, Tiffeneau-Pinelli index (FEV1/FVC\%), rate of peak expiratory flow (FEF/PEF), expiratory flow capacity FVC between $25 \%$ and $75 \%$ of graph (FEF25\%, FEF50\%, FEF75\% ); we studied correlation between FEV1 dynamics and various gradation of Mmrc gradation of self-evaluation questionnaire - (Modified Medical Research Council Questionnaire) [14].

Methods: The study was done on the base of "Acad. N. Kipshidze Central University Clinic", LLC, on the background of COPD patients' monitoring. During the research clinical assessment of patients was conducted according their demographic (gender, age), constitutional (BMI), COPD provocating risk-factors (smoking - active or former smoker), accompanying disorders and subjective assessment questionnaire (mMRC, CAT). Assessment of COPD patients by the questionnaire given by Council of Medical Research (mMRC - Modified Medical Research Council Questionnaire) allows to assess patients' clinical status [2][5] and risk of lethality [13][12]. In combination with data received by mMRC spirometry it gives additional information on prognosis of future complication risks. For assessment of Dyspnea scale relation of dyspnea development to different physical activity is given and it is assessed from 0 (respiratory insufficiency at intensive physical load) to 5 points (dyspnea at insignificant physical activity) [18]. Assessment of functional status of lung was conducted by spirometry. Degree of COPD severity was assessed by GOLD criteria (GOLD 1 - mild: FEV1/FVC $<0,70$, FEV $1 \geq 80 \%$ of expected, GOLD 2 - average: FEV1/FVC $<0,70,50 \% \leq \mathrm{FEV} 1<80 \%$ of expected, GOLD 3 - severe: FEV1/FVC $<0,7030 \% \leq$ FEV1 $<50 \%$ of expected, GOLD $4-$ too severe: FEV1/FVC $<0,70$,FEV1 $<30 \%$ of expected). Spirometry was conducted every 3 months to 
patients and detailed analysis of results was done. 78 patients were involved in research, study contingent demographic and clinical characteristics are given : Gender- Male -50 (64,10\%), Female28 (35,90\%), Age 61,56 $\pm 10,72$, Age of starting COPD complaints-54,92 $\pm 10,52$, Duration of COPD-6,64 \pm 4,05, Former Smoker-50,00 (64,10\%), Smoker-28,00 (35,90\%), P/Y-35,21 \pm 25,72, Duration of smoking-28,45 $\pm 10,77$, BMI-28,45 $\pm 10,77$, Normal Body Mass-20(25,64\%), Excessive weight-18(23,08\%), Obesity-40(51,28\%), Treatment in History- Was not treated-26 (33,33\%), Salbutamol-28(35,90\%), Combined therapy-24 (30,77\%), Exacerbation in history- No-62 (79,49\%), Yes-16(20,51\%), Mmrc-gradation- Grade2- 42(53,85\%), Grade3- 36(46,15\%), Questionnaire on Lung function-12,36 $\pm 2,78$, Arterial Hypertension-70(89,74\%), CAD. angina of effort -26(33,33\%), Heart failure-10(12,82\%), Atrial fibrillation-2 (2,56\%), Sd 2-16(20,51\%), dl-38(48,72\%), Tqd$2(2.56 \%)$.

Statistics: Results were processed statistically by the soft SPSS 22.0. Quantitative data were compared between groups using Students' t criteria. Correlations were studied using Pearson's correlation coefficient. $\mathrm{p}<0.05$ was accepted as criteria for reliability of results.

Results: In the beginning of the study correlation of pulmonary functional indices with FEV1 indices is given in table \#1.

Table \#1. Correlation of Pulmonary Functional Indices in the Beginning of the Study (parts of reliable correlations are colored).

\begin{tabular}{|l|c|c|c|c|c|c|c|c||}
\hline \begin{tabular}{|} 
Index (mark in \\
model)
\end{tabular} & FEV1 & FVC & $\begin{array}{c}\text { FEV1/ } \\
\text { FVC }\end{array}$ & $\begin{array}{c}\text { FEF } \\
(\text { PEF) }\end{array}$ & $\begin{array}{c}\text { FEF 25- } \\
75 \%\end{array}$ & $\begin{array}{c}\text { FEF } \\
25 \%\end{array}$ & $\begin{array}{c}\text { FEF } \\
50 \%\end{array}$ & FEF 75\% \\
\hline FEV1 (Y) & & $\mathbf{0 . 6 1 7 9}$ & $\mathbf{0 . 4 7 6 6}$ & $\mathbf{0 . 2 9 0 8}$ & $\mathbf{0 . 2 7 4 1}$ & $\mathbf{0 . 4 1 4 4}$ & $\mathbf{0 . 5 0 5 2}$ & $\mathbf{0 . 4 4 5 5}$ \\
\hline FVC (X1) & $\mathbf{0 . 6 1 7 9}$ & & $\mathbf{- 0 . 2 7 3 6}$ & 0.0874 & 0.0348 & 0.1703 & 0.0445 & 0.0677 \\
\hline FEV1/FVC (X2) & $\mathbf{0 . 4 7 6 6}$ & $\mathbf{- 0 . 2 7 3 6}$ & & $\mathbf{0 . 4 3 8 2}$ & $\mathbf{0 . 2 3 5 4}$ & $\mathbf{0 . 6 3 7 4}$ & $\mathbf{0 . 5 9 7 6}$ & $\mathbf{0 . 4 4 0 5}$ \\
\hline FEF (PEF) (X3) & $\mathbf{0 . 2 9 0 8}$ & 0.0874 & $\mathbf{0 . 4 3 8 2}$ & & 0.0626 & $\mathbf{0 . 6 1 1 5}$ & $\mathbf{0 . 3 5 2 1}$ & -0.1617 \\
\hline FEF 25-75\% (X4) & $\mathbf{0 . 2 7 4 1}$ & 0.0348 & $\mathbf{0 . 2 3 5 4}$ & 0.0626 & & $\mathbf{0 . 2 5 0 5}$ & $\mathbf{0 . 3 1 9 4}$ & $\mathbf{0 . 3 8 4 1}$ \\
\hline FEF 25\% (X5) & $\mathbf{0 . 4 1 4 4}$ & 0.1703 & $\mathbf{0 . 6 3 7 4}$ & $\mathbf{0 . 6 1 1 5}$ & $\mathbf{0 . 2 5 0 5}$ & & $\mathbf{0 . 7 7 5 9}$ & $\mathbf{0 . 4 7 7 5}$ \\
\hline FEF 50\% (X6) & $\mathbf{0 . 5 0 5 2}$ & 0.0445 & $\mathbf{0 . 5 9 7 6}$ & $\mathbf{0 . 3 5 2 1}$ & $\mathbf{0 . 3 1 9 4}$ & $\mathbf{0 . 7 7 5 9}$ & & $\mathbf{0 . 7 2 1 7}$ \\
\hline FEF 75\% (X7) & $\mathbf{0 . 4 4 5 5}$ & 0.0677 & $\mathbf{0 . 4 4 0 5}$ & -0.1617 & $\mathbf{0 . 3 8 4 1}$ & $\mathbf{0 . 4 7 7 5}$ & $\mathbf{0 . 7 2 1 7}$ & \\
\hline & & & & & & & & \\
\hline
\end{tabular}

By multiple linear regressive analysis reliable correlation between such data of FEV1 and pulmonary functional status as FVC, FEV1/FVC and FEF 50\%, were revealed. Results clearly show that on the background of disorder progress and worsening pulmonary functional status parallel to FEV1 
decrease FEV1/FVC, FVC and FEF 50\% indices decrease reliably and synchronously which is the result of worsening pulmonary tissue airiness or vital capacity and functional abilities of peripheral airways on the background of disease progress.

Results of looking for correlation between functional indices in 30 months after starting the study are given in table \#2.

Table \#2 Correlation of Functional Indices in Study Dynamics (in 30 months after starting the study) (parts of reliable correlations are colored).

\begin{tabular}{|l|c|c|r|r|r|r|r|r||}
\hline \multicolumn{1}{|c|}{$\frac{\text { Index (mark in }}{\text { model) }}$} & FEV1 & FVC & \multicolumn{1}{|c|}{ FEV1/ } & $\begin{array}{c}\text { FEF } \\
\text { (PEF) }\end{array}$ & $\begin{array}{c}\text { FEF 25- } \\
\mathbf{7 5 \%}\end{array}$ & $\begin{array}{c}\text { FEF } \\
\mathbf{2 5 \%}\end{array}$ & $\begin{array}{c}\text { FEF } \\
\mathbf{5 0 \%}\end{array}$ & $\begin{array}{c}\text { FEF } \\
\mathbf{7 5 \%}\end{array}$ \\
\hline FEV1 (Y) & & $\mathbf{0 . 6 1 9 2}$ & $\mathbf{0 . 4 5 3 1}$ & $\mathbf{0 . 3 2 1 1}$ & 0.2107 & $\mathbf{0 . 3 1 1 1}$ & $\mathbf{0 . 2 7 3 9}$ & $\mathbf{0 . 2 9 8 4}$ \\
\hline FVC (X1) & $\mathbf{0 . 6 1 9 2}$ & & $-\mathbf{0 . 2 7 8 3}$ & -0.0466 & 0.0106 & 0.1964 & 0.0658 & 0.1040 \\
\hline FEV1/FVC (X2) & $\mathbf{0 . 4 5 3 1}$ & $-\mathbf{0 . 2 7 8 3}$ & & $\mathbf{0 . 4 7 8 2}$ & 0.1236 & 0.05906 & 0.1222 & 0.1614 \\
\hline FEF (PEF) (X3) & $\mathbf{0 . 3 2 1 1}$ & -0.0466 & $\mathbf{0 . 4 7 8 2}$ & & 0.0589 & 0.0477 & 0.0622 & -0.1238 \\
\hline FEF 25-75\% (X4) & 0.2107 & 0.0106 & 0.1236 & 0.0589 & & $\mathbf{0 . 7 5 6 9}$ & $\mathbf{0 . 8 3 6 9}$ & $\mathbf{0 . 7 7 3 1}$ \\
\hline FEF 25\% (X5) & $\mathbf{0 . 3 1 1 1}$ & 0.1964 & 0.05906 & 0.0477 & $\mathbf{0 . 7 5 6 9}$ & & $\mathbf{0 . 8 1 6 9}$ & $\mathbf{0 . 6 5 8 0}$ \\
\hline FEF 50\% (X6) & $\mathbf{0 . 2 7 3 9}$ & 0.0658 & 0.1222 & 0.0622 & $\mathbf{0 . 8 3 6 9}$ & $\mathbf{0 . 8 1 6 9}$ & & $\mathbf{0 . 7 9 3 6}$ \\
\hline FEF 75\% (X7) & $\mathbf{0 . 2 9 8 4}$ & 0.1040 & 0.1614 & -0.1238 & $\mathbf{0 . 7 7 3 1}$ & $\mathbf{0 . 6 5 8 0}$ & $\mathbf{0 . 7 9 3 6}$ & \\
\hline \hline
\end{tabular}

In 30 months after starting the study multiple linear regressive analysis of correlations with FEV1 reliably confirmed existence of such relations as ones revealed in the beginning of the study between FEV1 and FVC, FEV1/FVC and FEF 50\% ( $\mathrm{p}<0.0001$ ). The abovementioned denotes that FVC, FEV1/FVC and FEF $50 \%$ are indices of pulmonary functional status which are in direct proportional correlation with FEV1 index. Obstructive type of ventilation disturbance is characterized with decrease in FEV1/FVC ratio on the background of normal FVC[22], on the background of disease progress airiness of pulmonary tissue decreases and correspondingly vital capacity of lungs (FVC) decreases as well, however, despite importance of the issue, looking for correlation of other spirometry indices with dynamics of FEV1 decrease is still the field of observation in the medicine. Dynamics of FEV1 in the purpose of finding correlation between the gradations of dyspnea selfevaluation questionnaire and speciphic treatment (or if such does not exist) conducted in anamnesis study contingent was divided in three groups: the group \#1 - untreated patients $(n=26)$; the group \#2 - patients taking salbutamol monotherapy $(n=28)$, the group \#3 - patients taking combined therapy $(n=24)$. 
Diagram \#1 Distribution of FEV1 average indices (expressed in Liters) in all three groups

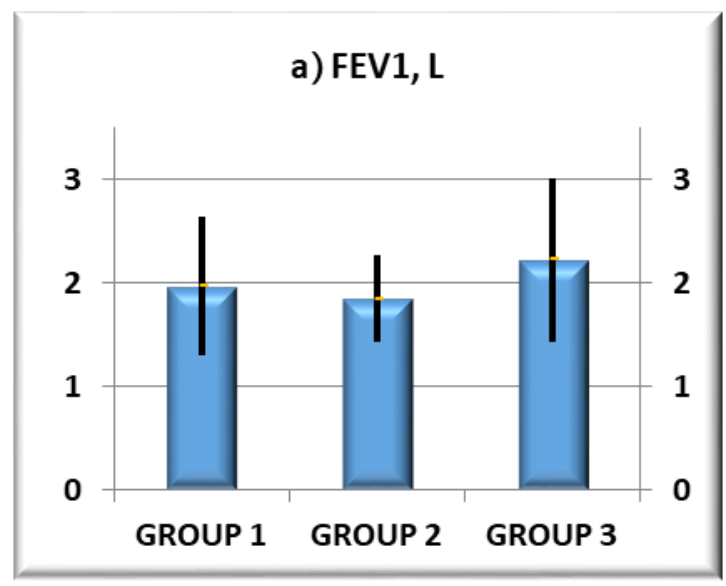

As study results showed average index of FEV1 in liters is reliably increased in the third group of patients, i.e. patients in whom treatment of COPD is started with combined inhalational therapy, which clearly shows priority of mentioned treatment in dynamics in the view of FEV1 indices improvement. In all three groups we studied correlation between FEV1 dynamics and gradations of dyspnea self-evaluation questionnaire and in the third group clearly it was revealed that average index of FEV1 in liters is reliably increased, dyspnea self-evaluation questionnaire index is reliably improved which is a strong index of correlation between FEV-1 index and gradations of dyspnea self-evaluation questionnaire in COPD patients, which once again underlines importance of wide use of self-evaluation questinnaire and revealing risk-groups by its analysis in which severe and unreliable course of disorder is anticipated.

Distribution of scores revealed by dyspnea self-evaluation questionnaire in mentioned groups is given in table \#3.

Table \#3 Distribution of Scores Counted by Dyspnea Self-Evaluation Questionnaire in Groups

\begin{tabular}{|c|c|c|c|}
\hline Parameters & Group 1 & Group 2 & Group 3 \\
\hline Score by the questionnaire of pulmonary function & $\mathbf{1 1 , 0 0} \pm 3,02$ & $\mathbf{1 2 , 8 6} \pm 2,49$ & $\mathbf{1 3 , 2 5} \pm 2,33$ \\
\hline \multicolumn{2}{|c|}{$\mathbf{p}_{\mathbf{1 - 2}}=\mathbf{0 . 0 1 7 7}$} & $\mathbf{p}_{\mathbf{1 - 3}}=\mathbf{0 . 0 0 5 5}$ & $\mathrm{p}_{2-3}=0.5646$ (NS) \\
\hline
\end{tabular}

Conclusion: 1.In the result of study reliable correlation was revealed between such indices of FEV1 and pulmonary functional status as FVC, FEV1/FVC @s FEF 50\%. Results clearly show that parallel to the worsening of pulmonary functional status and decrease in FEV1 such spirometric indices as FEV1/FVC, FVC and FEF 50\% synchronously and reliably decrease and this indicates close correlation between these indices and parallel to progress of disorder abrupt worsening of pulmonary vital capacity and functional abilities of peripheral airways.

2.Timely started treatment of COPD with combined inhalators of long-acting $\beta 2$ agonists and steroids reliably is associated with significant improvement of FEV1 indices in dynamics. 
3.In the result of study correlation between FEV-1 index and gradations of dyspnea self-evaluation questionnaire is statistically reliable in COPD patients which increases value of self-evaluation questionnaire in the view of prognosis of disorder severity and anticipated complications or undesirable course.

Thus, considering study results, it is possible to give some practical recommendations which helps further desirable course of COPD, prevention of complications and less severe outcome.

1.Timely and adequate treatment of COPD is significant factor for reliable prognosis of disease. 2.Wide implementation and popularization of spirometry is the most important factor for timely diagnosis of COPD in risk groups which itself is quite significant for starting adequate and timely treatment and impeding progress of desease.

3.Wide implementation and popularization of self-evaluation questionnaire will significantly help in revealing risk-group of COPD patients in whom severe and undesirable course of disease is expected.

\section{REFERENCES}

1. Almagro P, Soriano JB, Cabrera FJ, et al; Working Group on COPD, Spanish Society of Internal Medicine. Short- and medium-term prognosis in patients hospitalized for COPD exacerbation: the CODEX index. Chest. 2014 May;145(5):972-80.

2. Anelise B Munari, Aline A Gulart, Karoliny dos Santos, Raysa S Venâncio, Manuela Karloh and Anamaria F Mayer Respiratory Care January 2018, 63 (1) 77-85; DOI: https://doi.org/10.4187/respcare.05636

3. Frank E, Speizer MD, Ware JH. Exploring Different Phenotypes of COPD. N Engl J Med 2015, 373:185-186.

4. Gavidia M. COPD Mortality Rate Drops in Some Countries, While Total Mortality Rises, Study Finds. AJMC, Assessed on: November 27, 2019 at https: //www.ajmc.com/view/copdmortality-rate-drops-in-some-countries-while-total-mortality-rises-study-finds

5. Global Initiative for Chronic Obstructive Lung Disease. Global strategy for the diagnosis, management, and prevention of chronic obstructive pulmonary disease. Updated 2017, http://goldcopd.org/gold-2017-global-strategy-diagnosis-management-prevention-copd/

6. Guo Y, Zhang T, Wang Z, et al. Body mass index and mortality in chronic obstructive pulmonary disease: A dose-response meta-analysis. Medicine (Baltimore) 2016;95:e4225. 10.1097/MD.0000000000004225

7. Hurst JR, Vestbo J, Anzueto A et al. Susceptibility to exacerbation in chronic obstructive pulmonary disease. N Engl J Med, 2010, 363:1128-1138.

8. Iribarren M. R, Pérez T. A, Gómez Punter R.A, Noval A. R., Soriano J. B, Bermúdez J. A, Vázquez Espinosa E . Smoking habit in COPD patients European Respiratory Journal 2019 54: PA4488; DOI: 10.1183/13993003.congress-2019.PA4488 .

9. Lortet-Tieulent J, Soerjomataram I, López-Campos JL, et al. International trends in chronic obstructive pulmonary disease mortality, 1995-2017. Eur Respir J, 2019, 54(6):1901791. doi: 10.1183/13993003.01791-2019.

10. Lowe KE, Regan EA, Anzueto A et al. COPD Gene 2019: redefining the diagnosis of chronic obstructive pulmonary disease. Chronic Obstr Pulm Dis. 2019, 6(5): 384-399.

11. Matarese A, Sardu C, Shu J, Santulli G. Why is chronic obstructive pulmonary disease linked to atrial fibrillation? A systematic overview of the underlying mechanisms. Int J Cardiol, 2019, 276:149-151. 
12. Nishimura K, Izumi T, Tsukino M, Oga T. Dyspnea is a better predictor of 5-year survival than airway obstruction in patients with COPD. Chest 2002; 121(5): 1434-40.

13. Sundh J, Janson C, Lisspers K, Stallberg B, Montgomery S. The Dyspnoea, Obstruction, Smoking, Exacerbation (DOSE) index is predictive of mortality in COPD. Prim Care Respir $\mathbf{J}$ 2012; 21(3): 295-301.

14. Sunmin Kim' Jisun Oh' ,Yu-Il Kim, Differences in classification of COPD group using COPD assessment test (CAT) or modified Medical Research Council (mMRC) dyspnea scores: a cross-sectional analyses, BMC Pulmonary Medicine, Published: 03 June 2013

15. Vestbo J, Hurd SS, Agustí AG et al. Global strategy for the diagnosis, management, and prevention of chronic obstructive pulmonary disease: GOLD executive summary. Am J Respir Crit Care Med, 2013, 187:347-365

16. Авдеев С. Н. Стратегии профилактики обострений хронической обструктивной болезни легких // Доктор.Ру. 2017. № 10 (139)

17. Будневский, А. В. Биомаркеры как предикторы исходов хронической обструктивной болезни легких (обзор литературы) / А. В. Будневский, Е. С. Овсянников, А. В. Чернов, 2014. — № 5 (64). — C. 125-128. — URL: https://moluch.ru/archive/64/10332/ (дата обращения: 22.09.2020).

18. https:/www.moh.gov.ge/uploads/guidelines/2017/06/07/220973bd4d84475ad37c50818b23a8 5c.pdf 


\title{
ДИАГНОСТИЧЕСКИЕ ОСОБЕННОСТИ ЗЛОКАЧЕСТВЕННЫХ ОПУХОЛЕЙ ДЕТЕЙ ПЕРВОГО ГОДА ЖИЗНИ
}

\author{
${ }^{1}$ Айгуль Базарбаева, ${ }^{2}$ Азамат Кубиев, ${ }^{3}$ Дария Бекбатырова, ${ }^{3}$ Аяулым Нуртлеуова \\ ${ }^{1}$ Руководитель по науке и образованию, АО «Научный центр педиатрии и детской хирургии», кандидат \\ медицинских наук, Алматы, Республика Казахстан, Email: Bazarbaeva_aigul@mail.ru \\ ${ }^{2}$ Резидент 2-го года обучения по специальности «Онкология и гематология детская», НАО «Казахский \\ национальный медицинский университет С.Д. Асфендиярова», АО «Научный центр педиатрии и детской \\ хирургии», Алматы, Республика Казахстан, \\ ${ }^{3}$ Резидент 1-го года обучения по специальности «Онкология и гематология детская», НАО «Казахский \\ национальный медицинский университет С.Д. Асфендиярова», АО «Научный центр педиатрии и детской \\ хирургии», Алматы, Республика Казахстан, \\ ${ }^{4}$ Резидент 1-го года обучения по специальности «Онкология и гематология детская», НАО «Казахский \\ национальный медицинский университет С.Д. Асфендиярова», АО «Научный центр педиатрии и детской \\ хирургии», Республика Казахстан
}

\section{РЕЗЮМЕ}

В работе представлены структура, диагностические особенности и результаты лечения злокачественных новообразований (ЗН) детей первого года жизни. Проведен ретроспективный анализ 170 детей в возрасте от 0 до 12 месяцев с различными ЗН, с 2015 по 2019 гг.в условиях НЦПДХ. У детей первого года жизни солидные опухоли составили 76\%, гемобластозы 24\%, из которых 53\% были дети с ОМЛ, 45\% с ОЛЛ, с ХМЛ 2\%. Различные транслокации выявлены у 11\% детей с острым лейкозом, среди которых реаранжировки гена MLL выявлены в 64\% случаев острого лимфобластного лейкоза Наличие амплификации N-mic пациентов с нейробластомами составили 20\%. Общая выживаемость детей с солидными опухолями детей до 1 года составил 70\%, Процент выживаемости детей с гемобластозами составил 46\%.

Ключевые слова: злокачественные новообразования, дети до 1 года

Актуальность: Злокачественные опухоли у детей первого года жизни являются глобальной проблемой современности, обладают целым рядом особенностей, как в структуре, так и во времени выявления, отличающих их от опухолей у детей старшего возраста $[1,2,3]$.

Результаты исследования: Проведен ретроспективный анализ 170 детей в возрасте от 0 до 12 месяцев с различными злокачественными новообразованиями (3Н), госпитализированных в Научный центр педиатрии и детской хирургии за период с 2015 по 2019 гг. Учитывались: время постановки диагноза, разновидность, иммунологический и гистологический вариант опухоли, наличие генетических транслокаций. Общую выживаемость (OB) рассчитывали по методу Каплана-Майера. Количество выявленных ЗН в данной возрастной группе в среднем составило 34 случаев в год (2015г.-35, 2016г.-34, 2017г.-50, 2018г.-30, 2019г-20). В структуре преобладали ретинобластомы - $(22 \%)$, лейкозы - 20\%, нейробластома -20\%, нефробластомы -9\%, гепатопластома-8\%, герминогенные опухоли 8\%. Опухоли ЦНС и лимфомы встречались очень редко по 1\%, опухолей костей не зарегистрировано. Различные транслокации выявлены у 11\% детей с ОЛ, среди которых реаранжировки гена MLL выявлены в 64\% случаев ОЛЛ, 
наличие амплификации N-mic пациентов с нейробластомами составили 20\% (у 4 из 20). Среди пациентов с солидными опухолями процент общей выживаемости составил 70\%, Процент выживаемости детей с гемобластозами составил 46\% (рисунок 1-2).

Выводы: Выявлено преобладание эмбриональных опухолей (76\%):

В структуре острых лейкозов отмечен высокий процент ОМЛ (53\%), среди которых выявлен большой процент прогностически неблагоприятного M7 варианта, что показывает кардинальную разницу в стуктуре ОЛ в данной возрастной группе.

В 29 \% случаев возраст на момент постановки диагноза составил старше 6 месяцев, тогда как пренатально диагностированы только 5\%

Рисунок 1- Общая 5-летняя выживаемость детей до года с солидными опухолями

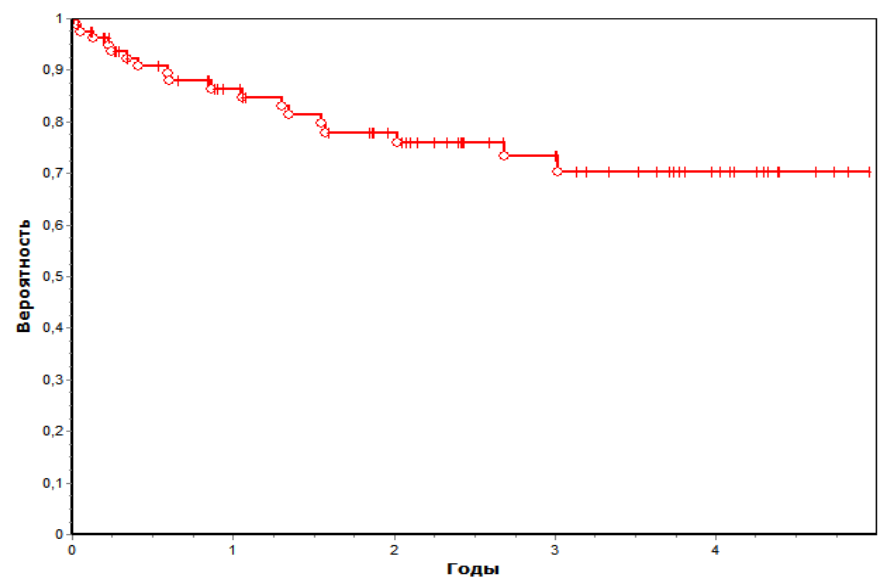

Рисунок 2 - общая выживаемость детей с гемобластозами

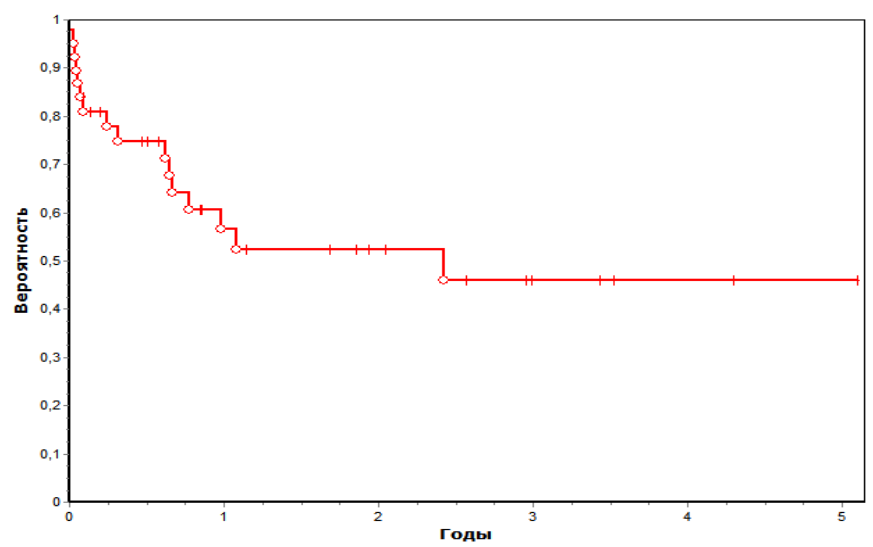

\section{ЛИТЕРАТУРА}

1. Global health observatory: the data repository [website]. Geneva: World Health Organization; 2017 (http://www.who.int/gho/database/en, accessed 30 January 2017).

2. Ferlay J, Soerjomataram I, Ervik M, Dikshit R, Eser S, Mathers C et al. GLOBOCAN 2012 v1.0, Cancer Incidence and Mortality Worldwide: IARC CancerBase No. 11 [Internet]. Lyon, 
France: International Agency for Research on Cancer; 2013 (http://globocan.iarc.fr, accessed 1 October 2016).

3. Global Action Plan for the Prevention and Control of Noncommunicable Diseases 20132020. Geneva: World Health Organization; 2013 (http://apps.who.int/iris/ bitstream/10665/94384/1/9789241506236_eng.pdf, accessed 1 October 2016). 


\title{
PROGNOSTIC VALUE OF N-MYC GENE AMPLIFICATION IN PATIENTS WITH NEUROBLASTOMA
}

\author{
${ }^{1}$ Zhumadullaev B.M. , ${ }^{2}$ Saduova Zh.G., ${ }^{3}$ Uskenbayeva A.A., ${ }^{3}$ Nurzhanova G.A., \\ ${ }^{4}$ Yeginbergenova D.M., ${ }^{5}$ Nazarova A.M.
}

\begin{abstract}
${ }^{1}$ Head of the department of surgery, candidate of medical sciences, «Scientific Centre of Pediatrics and children's surgery», Candidate of Medical Sciences, Kazakhstan.

${ }^{2}$ Resident in the specialty "Pediatric oncology and hematology", «NMU» named after S.D. Asfendiyarov JSC, «Scientific Centre of Pediatrics and children's surgery» JSC, Kazakhstan.

${ }^{3}$ Resident in the specialty "Pediatric oncology and hematology", «NMU» named after S.D. Asfendiyarov JSC, «Scientific Centre of Pediatrics and children's surgery» JSC, Kazakhstan.

${ }^{4} \mathrm{Head}$ of the department of oncohematology 2, «Scientific Centre of Pediatrics and children's surgery» JSC, Kazakhstan, ${ }^{5}$ Resident in the specialty " Pediatric oncology and hematology", «NMU» named after S.D. Asfendiyarov JSC, Kazakhstan, Almaty, «Scientific Centre of Pediatrics and children's surgery» JSC, Kazakhstan.

${ }^{6}$ Resident in the specialty " Pediatric oncology and hematology", «NMU» named after S.D. Asfendiyarov JSC, Kazakhstan, Almaty, «Scientific Centre of Pediatrics and children’s surgery» JSC, Kazakhstan.

Email: bahram1967@mail.ru
\end{abstract}

\begin{abstract}
This work presents the results of studying the prognostic value of the N-MYC gene amplification in patients with neuroblastoma treated according to the European protocol NB-2004. A retrospective analysis of 140 patients who were diagnosed with neuroblastoma from 2013-2019 was carried out at the SCP and PS. When collecting data from 140 patients with neuroblastoma, amplification of the NMYC gene was found in 26 patients, of which 19 patients died (73\%), 7 patients are alive (survival rate $-27 \%$ ). Amplification of the NMYC gene occurred with the same frequency in boys and girls, $50 \%$ in each group. In children under one year old, there were 6 children $(23.1 \%), 1-2$ years old 12 patients (46.2\%), 2-5 years old 5 children (19.2\%), over 5 years old 3 patients $(11.5 \%)$. In $13(50 \%)$ children, the primary tumor was localized in the adrenal glands, in $11(42 \%)$ - in the retroperitoneal space and in $2(7.7 \%)$ in the mediastinum. In $21(80.8 \%)$ patients with amplification of the N-MYC gene, the disease was diagnosed at stage IV, in 2 cases (7.7\%) with stage IVs, and $1(3.8 \%)$ case at I, II, III stage of the disease. Thus, patients with N-MYC gene amplification were more often detected at stage IV of the disease and had an unfavorable outcome.The fact of the negative impact of amplification of the N-MYC gene is confirmed in our study. The therapeutic protocol is ineffective in the presence of N-MYC gene amplification (survival - 27\%).
\end{abstract}

Keywords: Neuroblastoma, NMYC gene amplification, prognosis, children.

\section{Introduction:}

Relevance: Neuroblastoma (NB) - an embryonic malignant tumor of childhood, is a common extracranial solid tumor.

Amplification of the N-MYC gene in patients with NB is one of the main indicators of the aggressiveness of the disease, early resistance to chemotherapy, and poor prognosis [1-4]. 
Results: To study the prognostic value of N-MYC gene amplification in patients with NB treated according to the European protocol NB-2004 at the SCP and PS of the city of Almaty, Republic of Kazakhstan from 2013 to 2019.

During data collection, 140 patients with NB were identified; we found amplification of the N-MYC gene in 26 children, 19 of them died (73\%),7 patients are alive (survival rate -27\%). Comparative analysis was carried out according to the following parameters: age at the time of diagnosis, gender, stage of the disease, tumor localization. Amplification of the NMYC gene occurred with the same frequency in boys and girls, 50\% in each group. In children under one year old, there were 6 children (23.1\%), 1-2 years old 12 patients (46.2\%), 2-5 years old 5 children (19.2\%), over 5 years old 3 patients $(11.5 \%)$. In $13(50 \%)$ children, the primary tumor was localized in the adrenal glands, in 11 $(42 \%)$ - in the retroperitoneal space and in $2(7.7 \%)$ in the mediastinum. In $21(80.8 \%)$ patients with amplification of the N-MYC gene, the disease was diagnosed at stage IV, in 2 cases (7.7\%) with stage IVs, and $1(3.8 \%)$ case at I, II, III stage of the disease. Thus, patients with N-MYC gene amplification were more often detected at stage IV of the disease and had an unfavorable outcome.

Conclusions: The fact of the negative impact of amplification of the N-MYC gene is confirmed in our study. The therapeutic protocol is ineffective in the presence of N-MYC gene amplification (survival rate $-27 \%$ ).

\section{REFERENCES}

1. B. Zhumadullaev, G. Nurzhanova, B. Baizakova, S. Saliyeva, E.Krivenko, G. Algazyeva, K. Bertaeva, E. Iseeva, M. Remkulova, S. Baiturova, B.Elibaev, a. Bakisheva. G. Batyrkhanova, M. Karazhanova, M. Ensepbayev, D.Kraiomov.. Neuroblastoma Treatment in Kazakhstan: Single Center Experience. Pediatric Blood \&Cancer, 2019; PO140 SIOP19-0390: S610 of S709.

2. Ward E., DeSantis C., Robbins A., Betsy K., Ahmedin J. Childhood and adolescent cancer statistics, 2014. CA Cancer J Clin 2014; 64(2):83-103.

3. Brodeur G. M., Bagatell R. Mechanisms of neuroblastoma regression. Nat Rev Clin Oncol 2014;11(12):704-13.

4. Ambros I.M., Zellner A., Roald B. Amann G., Ladenstein R., Printz D., Gadner H., Ambros P. F.. Tyrrole of ploidy, chromosome 1p, and Schwann cells in the maturation of neuroblastoma. N Engl J Med 1996; 334(23):1505-11. 


\title{
ХАРАКТЕРИСТИКА ПАЦИЕНТОВ О С ПЕРВИЧНЫМИ ИММУНОДЕФИЦИТНЫМИ СОСТОЯНИЯМИ
}

\author{
${ }^{1}$ Ляззат Манжуова, ${ }^{2}$ Айгуль Базарбаева, ${ }^{3}$ Наргиза Кахарова \\ 1Заместитель председателя Правления по научно-клинической и инновационной деятельности, кандидат \\ медицинских наук, АО «Научный центр педиатрии и детской хирургии», Казахстан, \\ Email: ljazat.manzhuova@mail.ru \\ ${ }^{2}$ Руководитель по науке и образованию, кандидат медицинских наук, АО «Научный центр педиатрии и детской \\ хирургии», Казахстан. \\ ${ }^{3}$ Резидент по специальности «Онкология и гематология детская», НАО «Казахский национальный медицинский \\ университет С.Д. Асфендиярова», АО «Научный центр педиатрии и детской хирургии», Казахстан.
}

\section{РЕЗЮМЕ}

В данной работе представлен анализ результатов ретроспективного исследования 76 пациентов с первичными иммунодефицитными состояниями (ПИДс), получивших лечения в НЦПДХ с 2013 по 2019 года. Среди них мальчиков было 70\%, девочек - 30\%. Выявляемость этих заболеваний преобладала в период с 2015 года по 2016год. Наиболее многочисленная группа в структуре случаев ПИДс, диагностированных в НЦПДХ, была представлена аутовоспалительными заболеваниями - 37\%. На втором и третьем месте находились гуморальные иммунодефициты по 21\% и дефекты фагоцитоза - $11 \%$. Длительность додиагностического периода составила от 3х месяцев до 9 лет и выше, в среднем 1год 7 месяцев. Средний возраст на момент диагностики ПИДс 3,5 года. Ведущим синдромом всех ПИДс оставались инфекционные осложнения, которые составили 52\% случаев и были представлены в основном пневмониями и рецидивирующими вирусными инфекциями. При проведении молекулярно-генетического исследования, генетически диагноз ПИДС был подтвержден в 24\% случаев. 8 пациентам была проведена ТГСК, данный метод показал эффективность в терапии детей с некоторыми видами ПИДс.

Ключевые слова: Первичные иммунодефицитные состояния, диагностика, генетическое исследование.

Введение: Первичные иммунодефицитные состояния (ПИДс) - это группа заболеваний, обусловленные генетическими нарушения системы иммунитета, характеризующиеся дефектами одного или нескольких ее компонентов. По литературным данным выделяют 9 групп ПИДс, основанных на диагностике более 250 известных генетических мутаций $[1,2]$.

Цель исследования: Изучение выявляемости ПИДс, клинических особенностей с оценкой эффективности терапии на базе Научного центра педиатрии и детской хирургии (НЦПДХ).

Материалы и методы исследования: Был проведен ретроспективный анализ 76 пациентов, получавших лечение в разные периоды с 2013 по 2019 годы. Полученные данные подвергнуты стандартным методам статистической обработки.

Результаты исследования: За период с 2013 по 2019 годы в НЦПДХ было выявлено 76 
случаев ПИДс. Среди них мальчиков было 54 (70\%), девочек - 23 (30\%). Выявляемость этих заболеваний в разные годы была различной, преобладала в период с 2015 года по 2016год (рисунок 1). Наиболее многочисленная группа в структуре случаев ПИДс, диагностированных в НЦПДХ, была представлена аутовоспалительными заболеваниями - 28 (37\%). На втором и третьем месте находились гуморальные иммунодефициты по 16 (21\%) и дефекты фагоцитоза - 9 (11\%). В практике НЦПДХ не встречались пациенты с дефектами врожденного иммунитета и фенокопии ПИД, вызванные соматическими мутациями. Длительность додиагностического периода составила от 3х месяцев до 9 лет и выше, в среднем 1год 7 месяцев. Средний возраст на момент диагностики ПИДс 3,5 года. Ведущим синдромом всех ПИДс оставались инфекционные осложнения, которые составили 52\% случаев и были представлены в основном пневмониями и рецидивирующими вирусными инфекциями (рисунок 2). Среди других симптомов ПИДс частыми были тромбоцитопения, БЦЖиты. При проведении молекулярно-генетического исследования, генетический диагноз ПИДс был подтвержден в 18 случаях (23,7\%). Среди пациентов нашего исследования ТГСК проведена 8 пациентам: 2пациентам с ТКИН, 2 пациентам с синдромом Вискотта-Олдрича, 4 - с ХГБ. Среди 8 пациентов, получивших ТГСК, живы 6 пациентов, 1 ребенок умер в раннем посттрасплантационном периоде в связи реактивацией цитомегаловирусной инфекции. В настоящее время живы 63 ребенка, умерли 10 детей от различных инфекционных и аутоиммунных осложнений, выбыли из наблюдения 3 детей.

Рисунок 1 (Динамика выявленных и наблюдаемых случаев ПИДс)

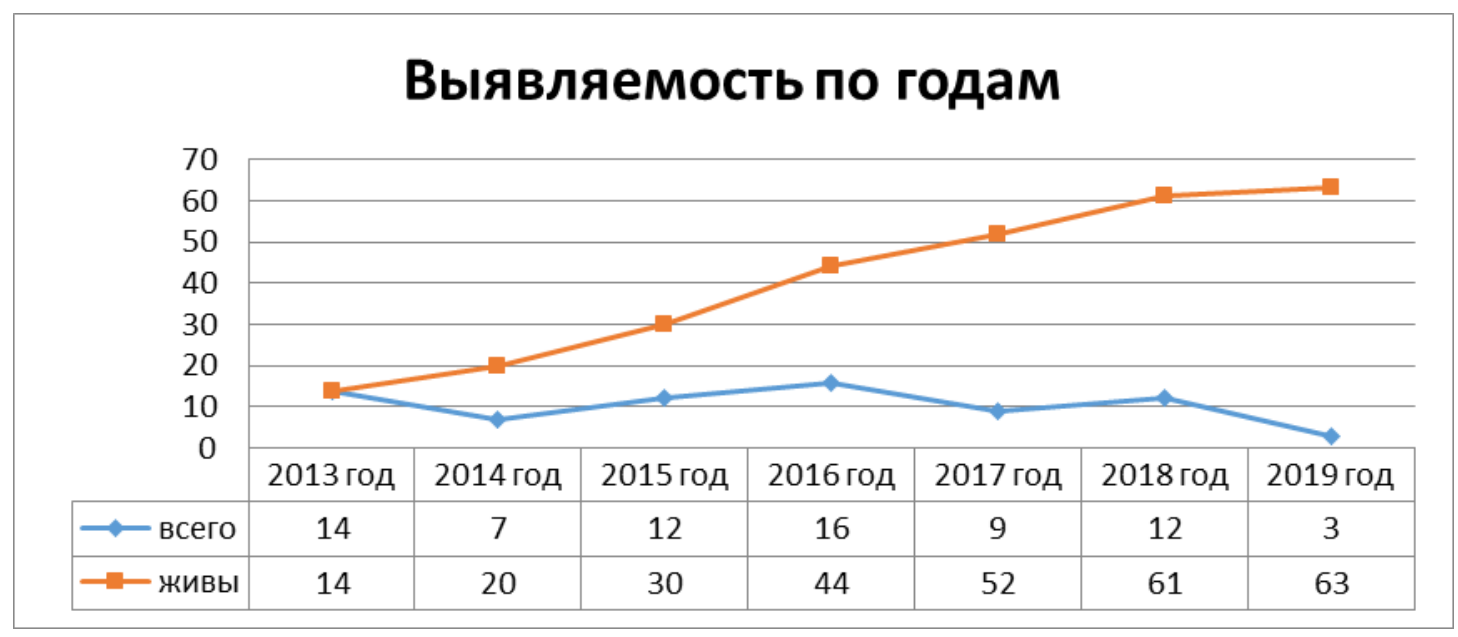

Рисунок 2 Частота встречаемости разных инфекционных осложнений в отдельных группах ПИДс 


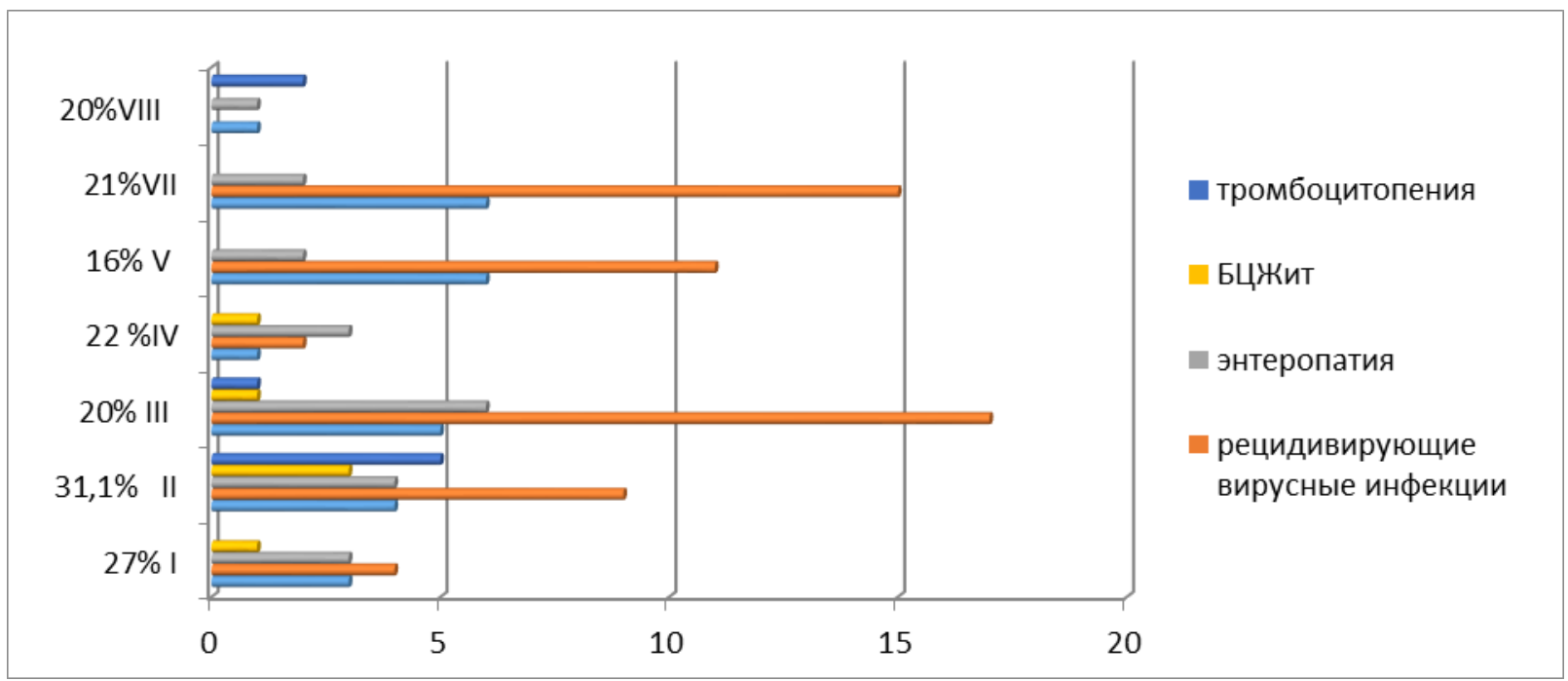

Выводы: В структуре случаев ПИДс, диагностированных в НЦПДХ, наибольшее количество случаев представлены аутовоспалительными заболеваниями - 37\%. Далее следуют гуморальные иммунодефициты (21\%) и дефекты фагоцитоза (17\%).

Низкая настороженность врачей первичного звена обусловила длительный додиагностический период, который составил от 3 месяцев до 9 лет, в среднем 1 год 7 месяцев.

ТГСК является эффективным методом терапии детей при некоторых видах ПИДс, дающий шанс на выживание и полное излечение.

\section{ЛИТЕРАТУРА}

1. AlAli A, Kletke S, Gallie B, Lam WC. Retinoblastoma for Pediatric Ophthalmologists. Asia Pac J Ophthalmol (Phila). 2018; 7(3): 160-168.

2. Gargallo P., Oltra J.S., Yáñez Y., Segura V., Balaguer J., Cañete A. Retinoblastoma: towards an earlier diagnosis. Arch Soc Esp Oftalmol. 2018; 93(9): 439-443 


\title{
АНАЛИЗ ОРГАНИЗАЦИИ МЕДИЦИНСКОЙ ПОМОЩИ ДЕТЯМ С ГЕМОФИЛИЯМИ В РЕСПУБЛИКЕ КАЗАХСТАН
}

\begin{abstract}
Лязат Манжуова
Заместитель председателя правления по научно-клинической работе АО «Научный центр педиатрии и детской хирургии», кандидат медицинских наук, Казахстан. Email: ljazat.manzhuova@mail.ru
\end{abstract}

\section{РЕЗЮМЕ}

Всего под динамическим наблюдением в Казахстане состоит 461 ребенок с наследственными нарушениями свертывания крови. Из них с гемофилией А - 344 ребенка. Дети с гемофилией в РК обеспечиваются факторами свертывания из Республиканского бюджета. На сегодняшний день на регулярной основе профилактическую заместительную терапию получают 313 детей со среднетяжелой и тяжелой формами гемофилии А. Остальные дети с легкой формой гемофилии получают факторы свертывания при факте кровотечения.

Всего зарегистрировано 37 случаев ингибиторной формы, что составило 10,7\% от всех случаев гемофилии А.

С 2012 года в РК начала проводиться терапия индукции иммунной толерантности (ИИТ), направленная на инактивацию ингибиторов путем воздействия высоких доз фактора VIII. Из 37 детей с ингибиторами, 19 детям начата терапия ИИТ. Полный ответ на терапию наблюдался у 5 детей. Еще у 4 детей наблюдается хорошая элиминация ингибитора, планируется перевод их на профилактическую терапию. У 4 детей сохраняются высокий уровень ингибиторов в крови, что расценено как неэффективность ИИТ. Остальные дети продолжают терапию.

Диагностика и терапия детей с гемофилией в РК осуществляется в соответствии с мировой практикой. Распространенность заболевания составляет 6-7 случаев на 100000 детского населения. Сопоставимость с мировой статистикой свидетельствует о достаточном уровне диагностике заболевания.

Ключевые слова: Гемофилия А, индукция иммунной толерантности

Введение: На сегодня одним из самых генетически расшифрованных редких заболеваний в мире является гемофилия. Уже более двух десятков лет во всем мире благодаря применению препаратов факторов свертывания улучшилось качество жизни детей с гемофилией. Однако, сохраняющаяся высокой частота геморрагических проявлений, сложности в поддержании приверженности к терапии у пациентов, связанные с пожизненным регулярным внутривенным введением препаратов, ведут к разработке новых методов терапии $[1,2,3$.

Целью нашего исследования был анализ организации медицинской помощи детям с гемофилией в Республике Казахстан.

Результаты: проведен анализ статистических учетных форм, данные республиканской информационной системы «Электронный регистр диспансерного больного», данные карт динамического наблюдения дневного стационара Научного центра педиатрии и детской хирургии. Всего под динамическим наблюдением в Казахстане состоит 461 ребенок с наследственными нарушениями свертывания крови. Из них в структуре превалирует гемофилия А - 344 ребенка. Распространенность заболевания составляет 6-7 случаев на 
100000 детского населения. Сопоставимость с мировой статистикой свидетельствует о достаточном уровне диагностике заболевания.

В структуре гемофилии А наиболее частой является среднетяжелая форма - 43,9\%, несколько реже (40,7\%) тяжелая форма. Группа пациентов с легкой формой составляет 15,4\%.

С 2004 года дети с гемофилией в РК обеспечиваются факторами свертывания из Республиканского бюджета. На сегодняшний день на регулярной основе профилактическую заместительную терапию получают 313 детей со среднетяжелой и тяжелой формами гемофилии А. Остальные дети с легкой формой гемофилии получают факторы свертывания при факте кровотечения.

Одним из тяжелых осложнений заместительной терапии является развитие ингибиторов против фактора VIII или IX в результате чего гемостатическая терапия становится неэффективной [2,4]. Всего зарегистрировано 37 случаев ингибиторной формы, что составило $10,7 \%$ от всех случаев гемофилии А.

С 2012 года в РК начала проводиться терапия индукции иммунной толерантности (ИИТ), направленная на инактивацию ингибиторов путем воздействия высоких доз фактора VIII. Из 37 детей с ингибиторами, 19 детям начата была терапия ИИТ. Полный ответ на терапию наблюдался у 5 детей. Еще у 4 детей наблюдается хорошая элиминация ингибитора, планируется перевод их на профилактическую терапию. У 4 детей сохранялись частые гемартрозы и высокий уровень ингибиторов в крови, что расценено как неэффективность ИИТ. Остальные дети продолжают терапию.

Таким образом, диагностика и терапия детей с гемофилией в РК осуществляется в соответствии с мировой практикой, хотя еще имеются некоторые проблемы.

Выводы: Диагностика и терапия детей с гемофилией в РК осуществляется в соответствии с мировой практикой. Распространенность заболевания составляет 6-7 случаев на 100000 детского населения. Сопоставимость с мировой статистикой свидетельствует о достаточном уровне диагностике заболевания.

\section{ЛИТЕРАТУРА}

1. European Haemophilia Consortium. Available at: http://www.ehc.eu/ bleedingdisorders/haemophilia/ (in Russian).

2. Боранбаева Р.3., Омарова К.О., Манжуова Л.Н., Булабаева Г.Е., Байгоджаева А.К. Современные принципы лечения детей с гемофилией в Республике Казахстан. Педиатрия и детская хирургия. 2018; 2 (22): 18-19.

3. Gavrel M, Rafowicz A, d'Oiron R, Franchi-Abella S, Lambert T, Adamsbaum C. Imaging features of atypical bleeds in young patients with hemophilia. Diagn Interv Imaging. 2019;100(3): 35-145.

4. Боранбаева Р.3, Абдилова Г.К., Асламбекова Н.А. Эффективность лечения ингибиторных форм гемофилии у детей. Известия НАН РК.Серия биологическая. 2017; 5 (323): 34-38. 


\section{КЛИНИКО-ДИАГНОСТИЧЕСКИЕ ОСОБЕННОСТИ ДЕТЕЙ С ЛИМФОМОЙ ХОДЖКИНА}

\section{${ }^{1}$ Гаухар Нуржанова, ${ }^{2}$ Айгуль Базарбаева, ${ }^{3}$ Зухра Хашимова, ${ }^{4}$ Айгерим Ускенбаева}

1Заведующая отделением онкологии и гематологи 2, АО «Научный центр педиатрии и детской хирургии», Казахстан

${ }^{2}$ Руководитель по науке и образованию, АО «Научный центр педиатрии и детской хирургии», Казахстан,

Email: bazarbaeva_aigul@mail.ru

${ }^{3}$ Резидент по специальности «Онкология и гематология детская», НАО «Казахский национальный медицинский университет С.Д. Асфендиярова», АО «Научный центр педиатрии и детской хирургии», Казахстан, Етаil: foti.8080@mail.ru

${ }^{4}$ Резидент 2-го года обучения по специальности «Онкология и гематология детская», НАО «Казахский национальный медицинский университет С.Д. Асфендиярова», АО «Научный центр педиатрии и детской хирургии», Казахстан, Email: auskenbaeva@mail.ru

\section{РЕЗЮМЕ}

В работе представлены клинико- диагностические особенности лимфомы Ходжкина у детей. Проведен ретроспективный анализ 62 детей в возрасте от 0 до 18 лет с лимфомой Ходжкина, с 2013 по 2019 гг.в условиях Научного центра педиатрии и детской хирургии (Казахстан). Возрастной пик заболеваемости у детей преимущественно приходится на возраст с 10 до 18 лет, что составило 51,7\%. Из гистологических вариантов преобладал - нодулярный склероз (58\%). По локализации с поражением периферических лимфоузлов выявлено у 55 (88,7\%), лимфоузлов средостения у 4 (6,5\%), лимфоузлов, расположенных ниже диафрагмы у 3( 4,8\%). У большинства пациентов (около 88,3\%) заболевание регистрировано на II и III стадиях. $88,9 \%$ пациентов до постановки клинического диагноза лечились по месту жительства с различными инфекционными заболеваниями. Анализ ранних клинических проявлений лимфомы Ходжкина показал, что ошибки диагностики связаны, со сходством их симптоматики на начальных этапах развития с воспалительными заболеваниями. Отсутствие своевременного выявления и онконастороженность первичной медико-санитарной помощи и родителей приводит к поздней постановке диагноза

Ключевые слова: лимфома Ходжкина, дети, ранняя диагностика

Введение: Несмотря на успехи в лечении лимфомы Ходжкина до настоящего времени остается нерешенной проблема их ранней диагностики, что несомненно сказывается на отдаленных результатах лечения. [1].

Результаты исследования: Исследование основано на данных ретроспективного анализа 62 пациентов с лимфомой Ходжкина, в возрасте от 0 до 18 лет, находившихся в Научном центре педиатрии и детской хирургии с 2013 по 2019г. При оценке по возрасту - преобладали пациенты 10-15 лет - 32,3\% (20), реже 3-5 лет - 24,2\% (15), 6-9 лет - 24,2\% (15), 16 -18 лет $19,4 \%$ (12) . По половому признаку 53,2\% (33) мальчиков и 46,8\% (29) девочек. По локализации с поражением периферических лимфоузлов у 55 (88,7\%), лимфоузлов средостения у 4 (6,5\%), лимфоузлов, расположенных ниже диафрагмы выявлены у 3( 4,8\%). По гистологическим вариантам НС у 36(58\%), СМ-КЛ 11 (17,8\%), Л-ПР 11(17,8\%), ЛИ у 1 
$(1,6 \%)$, БДУ у 4(6,4). По стадиям наблюдались следующие показатели: 1 ст - 3(5\%), 2cт- 27 (45\%), 3ст- 26 (43,3\%), 4ст-4 (6,7\%). У 38(61,3\%) отмечалась В-симптоматика; у 24 (38,7\%) без интоксикации. У 72,2\% (26) до постановки клинического диагноза лечились по месту жительства с - острый лимфаденит; с острым бронхитом 11,1\% (4); с кардитом 2,8\% (1), эпидемическим паротитом 2,8\% (1), с неврологическими нарушениями 5,5\% (2), не лечились 2,8\% (1), своевременно обратились к детскому онкологу 2,8(1).

Выводы: Анализ ранних клинических проявлений лимфомы Ходжкина показал, что ошибки диагностики связаны, со сходством их симптоматики на начальных этапах развития с воспалительными заболеваниями. Отсутствие своевременного выявления и онконастороженность ПМСП, родителей приводит к поздней постановке диагноза.

\section{ЛИТЕРАТУРА}

1. "Клиническая онкогематология", издание 2-е, Руководство для врачей под ред. проф. Волковой М.А., Москва, Медицина, 2007, стр. 679 - 723.

2. Lister TA, Crowther D, Sutcliffe SB, et al. Report of a committee convened to discuss the evaluation and staging of patients with Hodgkin"s disease: Cotswolds meeting. J Clin Oncol 1989; 7: 1630 - 1636.

3. Демина Е.А., Тумян Г.С., Унукова Е.Н., и соавт. Современные возможности лечения первичных больных лимфомой Ходжкина и причины неудач лечения. Онкогематология. 2007; 2: 24 - 30.

4. Engert A, Franklin J, Eich HT et al. Two Cycles of Doxorubicin, Bleomycin, Vinblastine, and Dacarbazine Plus Extended-Field Radiotherapy Is Superior to Radiotherapy Alone in Early Favorable Hodgkin"s Lymphoma: Final Results of the GHSG HD7 Trial. JCO. 2007; 3495 3502

5. Meyer RM, Gospodarowicz MK, Connors JM, et al. ABVD Alone versus Radiation-Based Therapy in Limited-Stage Hodgkin"s Lymphoma. N Engl J Med. 2012; 366: 399 - 408. 


\title{
МОРФОЛОГИЯ КИШЕЧНО-АССОЦИИРОВАННЫХ ЛИМФОИДНЫХ ОБРАЗОВАНИЙ ТОНКОЙ КИШКИ БЕЛЫХ КРЫС В РАННЕМ ОНТОГЕНЕЗЕ
}

\author{
Т.А. Адайбаев, М.К. Жаналиева, Р.Н. Жарилкасимов \\ Кафедра анатомии человека, НАО «Медицинский университет Астана», Казахстан
}

Актуальность: Слизисто-ассоциированная лимфоидная ткань представляет собой неотъемлемый и важный элемент иммунокомпетентной системы организма [1,2]. Однако до сих пор остаются слабо освещенными вопросы о формировании лимфоидного аппарата периферических органов иммунной системы экспериментальных животных в раннем онтогенезе. Изучение структурных преобразований лимфоидной ткани, ассоциированной с кишечником, в основном с тонкой кишкой, в процессе антенатального и постнатального периодов развития необходима для понимания становления иммунологических функций лимфоидных образований в раннем периоде онтогенеза [3,4].

Цель исследования: Изучение микроанатомической организации и клеточного состава лимфоидных бляшек тонкой кишки у белых крысят в антенатальном и раннем постнатальном периодах развития.

Материалы и методы исследования: Материалом для морфологического исследования явились 36 тонкой кишки плодов и новорожденных белой крысы.

В эксперименте были учтены закономерности развития беременности у белых крыс [5]. Течение беременности у белых крыс состоит из четырех периодов: I - 3-5 сутки беременности (доимплантационный период); II - 7-9 сутки (ранний постимплантационный период); III - 13-15 сутки (период функционирования зрелой плаценты); IV - 19-21 сутки (период старения плаценты).

Экспериментальная группа состояла из четырех подгрупп животных в антенатальном периоде развития и постнатальном периоде онтогенеза (Таблица).

В работе были применены методы исследования, изложенные в классических руководствах по гистоморфологии [6]: анатомические - препарирование, макроскопическое описание, фиксация; гистологические - окраска гематоксилином и эозином, азур 11 - эозином; морфометрические - определение морфологических параметров лимфоидных образований тонкой кишки с помощью окуляр - микрометра МОВ 1-15 и окулярной измерительной сетки Автандилова под микроскопом МБИ-3 с бинокулярной насадкой АУ-12 [7]; метод статистического анализа - статистическая обработка результатов проведена по программе «Медико - биологическая статистика» (2001). Степень достоверности различия определяли с помощью коэффициента Стъюдента $(\mathrm{p} \leq 0,05)$. 
Таблица - Распределение экспериментального материала (крысята п = 36)

\begin{tabular}{|l|l|l|l|l|}
\hline \multirow{2}{*}{$\begin{array}{l}\text { Эксперимен } \\
\text { тальные животные }\end{array}$} & \multicolumn{3}{|l|}{ Возраст животных (в сутках) } \\
\cline { 2 - 5 } & Антенатальный период онтогенеза & \multicolumn{2}{l|}{ Постнатальный период онтогенеза } \\
\cline { 2 - 5 } & $13-16$ (I) & $17-21$ (II) & $1-4$ (III) & $5-7$ (IV) \\
\hline Белые крысята (п-36) & 9 & 9 & 9 & 9 \\
\hline
\end{tabular}

Результаты и их обсуждение: Лимфоидные образования тонкой кишки у потомства белых крыс начинают выявляться на 18-19 сутки антенатального развития. До этого срока, в местах развития лимфоидной ткани тонкой кишки наблюдались скопления мезенхимы с кровеносными сосудами.

На I этапе развития (18-19 сутки) у плодов белых крыс определяются зачатки органа $(1,9 \pm 0,09)$, содержащие стромальные клетки и малые лимфоциты.

К моменту рождения, т.е. 20-21 сутки внутриутробного развития (II этап развития) увеличивается количество лимфоидных бляшек в тонкой кишке. Паренхима лимфоидных бляшек представлена диффузной лимфоидной тканью. На данном этапе развития происходит рост процентного содержания малых лимфоцитов, появляются средние и большие лимфоциты, митотически делящиеся клетки и бласты. Преобладающим видом клеток являются стромальные клетки.

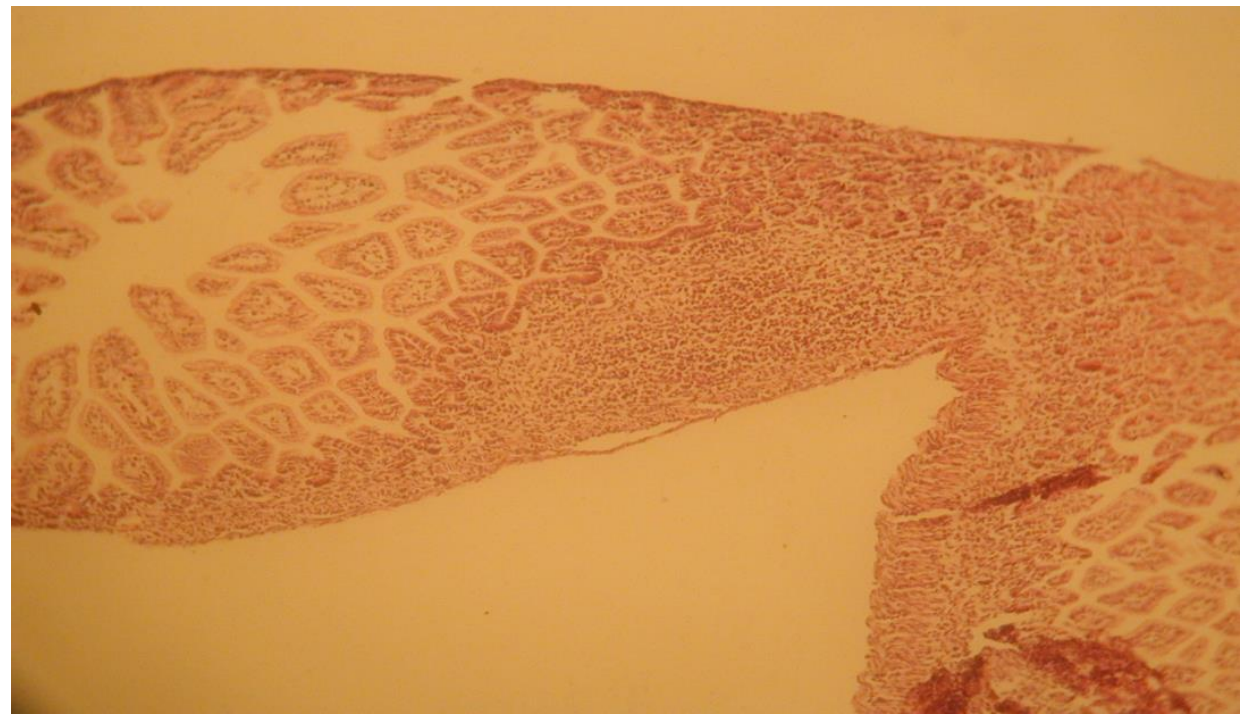

Диффузная лимфоидная ткань.

Окраска гематоксиином и эозином. Об. 10, ок. 10.

Рисунок - Зачаток лимфоидной бляшки тонкой кишки на 21 сутки антенатального развития плода белой крысы.

Таким образом, к моменту рождения наблюдались значительные изменения в клеточном составе лимфоидных бляшек тонкой кишки. 


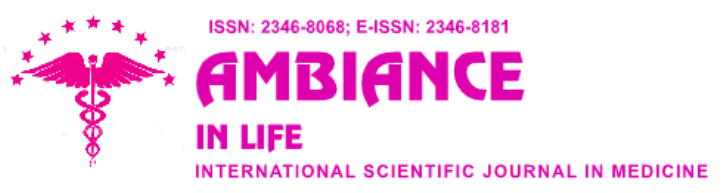

В течение III этапа продолжает увеличиваться количество лимфоидных бляшек и паренхима их сохраняет свое диффузное строение. На этом этапе развития происходит рост процента содержания всех видов клеток лимфоидного ряда, однако соотношение между ними изменяется. Так, у 1-4 суточных новорожденных крысят в диффузной лимфоидной ткани лимфоидных бляшек значимо увеличивается число малых лимфоцитов. Снижается доля стромальных клеток. Среди клеток лимфоидного ряда, после малых лимфоцитов по содержанию в диффузной лимфоидной ткани следуют средние и большие лимфоциты. На данном этапе развития начинают выявляться плазмоциты и макрофаги.

Ha IV этапе (5-7 сутки жизни) увеличивается количество бляшек в тонкой кишке в 2,4 раза. В паренхиме по-прежнему сохраняется диффузность лимфоидной ткани. Однако, лимфоидная ткань принимает вид лимфоидных узелков без светлых центров. Такое строение диффузная лимфоидная ткань принимает вследствие дифференцировки аргирофильных ретикулярных волокон. Наблюдается значительный рост всех видов клеток в паренхиме лимфоидных бляшек, однако при этом продолжает снижаться доля стромальных клеток, доля малых лимфоцитов резко возрастает. Увеличивается процент содержания средних и больших лимфоцитов, бластов и митозов. Резко возрастают показатели плазмоцитов и макрофагов. Появляются единичные дегенерирующие клетки.

Таким образом, в условиях физиологической жизнедеятельности у потомства белых крыс к концу IV этапа развития (7 сутки жизни) в лимфоидных бляшках тонкой кишки только начинается дифференцировка на В-зоны (лимфоидные узелки без светлых центров). Следовательно, на IV этапе развития лимфоидные бляшки не могут выполнять все свои иммунологические функции.

Выводы:1. В процессе становления микроанатомической организации и дифференцировки клеточного состава лимфоидных бляшек у потомства белых крыс можно выделить 4 этапа развития, которые соответствуют следующим срокам: I- этап - 18-19 сутки внутриутробного развития; II-этап - 20-21 сутки внутриутробного развития; III-этап - 1-4 сутки жизни постнатального периода; IV-этап - 5-7 сутки жизни постнатального периода развития.

2. Проведенные исследования позволяют лучше понять закономерности строения и развития органов иммуногенеза, позволяя стандартизировать морфологические данные в процессе физиологического онтогенеза.

3. Полученные данные могут быть использованы морфологами и иммунологами, как эталон, при исследований органов иммуногенеза и моделировании биологических экспериментов.

\section{ЛИТЕРАТУРА}

1. Сапин М.Р. Иммунная система и иммунодефицит //Клиническая медицина. - 1999. - Т. 77. - №1. - С. 5-11.

2. Морфометрическая характеристика лимфоидных узелков (пейеровых бляшек) тонкой кишки в онтогенезе // Universum: медицина и фармакология : электрон. научн. журн.

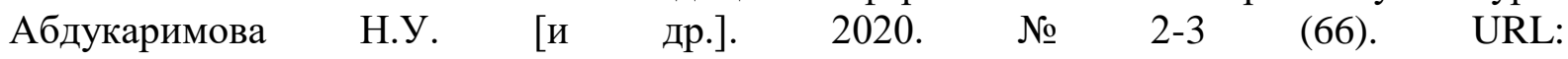
https://7universum.com/ru/med/archive/item/9059.

3. Хлыстова 3.С., Калинина И.И., Шмелёва С.П. и др. Последовательность встраивания лимфоидных органов в развивающуюся иммунную систему плода человека в перинатальной патологии //Архив патологии. - 2002. - №2. - С. 16-19. 
4. Аминова Г.Г. Цитоархитектоника лимфоидной ткани, ассоциированной со стенкой слепой кишки у человека в подростковом возрасте //Морфология.- 2002.-№ 4.-С. 53-55.

5. Кульбах О.С. Клеточный состав различных структурных зон подвздошных и брыжеечных узлов у крыс при беременности //Архив анатомии. - 1984. - Т.8. - Вып.4. C.39-45.

6. Лилли Р. Патогистологическая техника и практическая гистология. - Москва. 1969. - 645 c.

7. Автандилов Г.Г. Медицинская морфометрия. - Москва: «Медицина». -1990. - 290 с. 


\title{
ОПЫТ ПРОВЕДЕНИЯ ГАПЛОИДЕНТИЧНОЙ ТРАНСПЛАНТАЦИИ ГЕМОПОЭТИЧЕСКИХ СТВОЛОВЫХ КЛЕТОК С ИСПОЛЬЗОВАНИЕМ ТЕХНОЛОГИИ ИМУННОМАГНИТНОЙ СЕПАРАЦИИ ЛИМФОЦИТОВ
}

\author{
Куаныш Умбетов ${ }^{1}$, Аяулым Нуртилеуова ${ }^{2}$ \\ 1Заведующий отделения лаборатория афереза, контроля качества ГСК с отделением клинической \\ трансфузиологии, АО «Научный центр педиатрии и детской хирургии», Казахстан, Email: Uk-239@mail.ru \\ ${ }^{2}$ Резидент по специальности «Онкология и гематология детская», НАО «КазНМУ им.Асфендиярова», Казахстан, \\ Email: ankezhanova.gulmira@ mail.ru
}

\section{PEЗЮME}

В материале представлено мнение об эффективности деплеции альфа/бета-Т-лимфоцитов при трансплантации гемопоэтических стволовых клеток (ТГСК) от гаплоидентичных доноров, путем снижения риска реакции «трансплантат против хозяина» (РТПХ) и посттрансплантационных осложнений. Данная технология связана с внедрением Т-клеточной деплеции, в котором выделение из трансплантата только зрелых лимфоцитов несущих Тклеточный рецептор TCR $\alpha / \beta$,позволяет оставлять в трансплантанте только T-клетки несущие $\mathrm{TCR} \gamma \delta$ рецептор,которая не обладает аллореактивностью, и является профилактикой реакции трансплантата против хозяина. В нашем центре проведено 10 технологии деплеции TCR $\alpha / \beta$ и CD19 клеток с момента внедрения. Трансплантант заготавливается путем аферез ГСК+

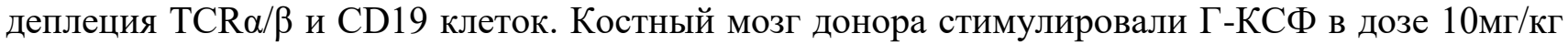
в течение 5 дней. Процедура афереза ГСК периферической крови проводилась на первый день ТГСК на автоматическом сепараторе клеток крови Spectra Optia (США). Сбор СК периферической крови по времени в среднем длилось 5,5 часа, объем собранного продукта афереза составило - 320мл ( \pm 40 мл). В нашем опыте полученный трансплантант при использовании технологии истощения TCR $\alpha / \beta$ и $\mathrm{CD} 19$ клеток соответствовал международным рекомендациям гаплоТГСК, а восстановление мегакариоцитарного и гранулоцитарного ростков у детей отмечались на $+15( \pm 4)$ день после ТГСК.

Ключевые слова: гаплоидентичная трансплантация гемопоэтических стволовых клеток

Введение: ТГСК последние десятилетия является безальтернативным методом лечения ряда агрессивных гемобластозов, синдромов костномозговой недостаточности и врожденных иммунодефицитов, и остается методом, ассоциированным с высоким риском развития тяжелых, подчас инвалидизирующих и смертельных осложнений [1,2]. Без сомнения, трансплантация гемопоэтических стволовых клеток (ГСК) от совместимого родственного и неродственного донора наиболее эффективный вариант при лечении злокачественных заболевании у детей и подростков. Тем не менее, для многих пациентов отсутствие совместимого донора является препятствием к своевременному проведению ТГСК, а поиск в международной базе доноров стволовых клеток (СК) занимает длительное время по отношению соматическому состоянию пациента. Отсюда следует, поиск альтернативных источников ГСК для трансплантации, к которым относится гемопоэтические стволовые клетки пуповинной крови или гаплоидентичный донор[3,4].

В 2016 году Научный центр педиатрии и детской хирургии впервые внедрил технологию разработанную совместно с группой ученных из Тюбингена(Германия), суть которой - 
внедрение Т-клеточной деплеции, где выделение из трансплантата только зрелых лимфоцитов несущих T-клеточный рецептор TCR $\alpha / \beta$,позволяет оставлять в трансплантанте только Tклетки несущие TCR $\gamma \delta$ рецептор, что не обладает аллореактивностью, и является профилактикой реакции трансплантата против хозяина.В нашем центре проведено 10 технологии деплеции TCR $\alpha / \beta$ и $\mathrm{CD} 19$ клеток с момента внедрения. Трансплантант заготавливается путем аферез ГСК+ деплеция TCR $\alpha / \beta$ и CD19 клеток. Костный мозг донора стимулировали Г-КСФ в дозе 10мг/кг в течение 5дней. Процедура афереза ГСК периферической крови проводилась на первый день ТГСК на автоматическом сепараторе клеток крови Spectra Optia (США). Сбор СК периферической крови по времени в среднем длилось 5,5 часа, объем собранного продукта афереза составило - 320мл ( \pm 40 мл), (таблица1). Собранный материал подвергся обработке по стандартному протоколу магнитной сепарации клеток при помощи аппарата CliniMacs, Miltenyi Biotec. В данной таблице 1 отражены обработка клеточного продукта согласно стандартного протокола. Результаты магнитной сепарации TCR $\alpha / \beta$ и CD19 клеток проанализированы, продукт сепарации отдельно.

Таблица 1. Магнитная очистка трансплантанта

\begin{tabular}{|c|c|c|c|c|}
\hline Названия продукта & $\begin{array}{l}\text { Стартовый } \\
\text { материал }\end{array}$ & $\begin{array}{l}\text { Оригинальный } \\
\text { продукт }\end{array}$ & $\begin{array}{l}\text { объем } \\
\text { полученного } \\
\text { продукта }\end{array}$ & $\begin{array}{l}\text { Удаленный } \\
\text { продукт }\end{array}$ \\
\hline Объем продукта & $\mathrm{V}-320 \mathrm{ml}$ & V-200 ml & $\mathrm{V}-350 \mathrm{ml}$ & $\mathrm{V}-250 \mathrm{ml}$ \\
\hline $\begin{array}{l}\text { Общая количество } \\
\text { лейкоцито }\end{array}$ & $\begin{array}{l}\text { WBC }-135.5 \\
\times 10^{9} / л( \pm 11)\end{array}$ & $\begin{array}{l}\text { WBC }-131.5 \times 10^{9} / \pi \\
( \pm 11)\end{array}$ & $\begin{array}{l}\text { WBC - } \\
203.5 \times 10^{9} / л( \pm \\
49)\end{array}$ & $\begin{array}{l}\text { WBC -49 } \\
\text { х109/л }( \pm 14)\end{array}$ \\
\hline Т-лимфоциты $\alpha / \beta$ & $\begin{array}{l}\text { TCR } \alpha / \beta-10.8 \\
\times 10^{9}( \pm 2)\end{array}$ & $\begin{array}{l}\mathrm{TCR} \alpha / \beta-10.1 \times 10^{9} \\
( \pm 2)\end{array}$ & $\begin{array}{l}\text { TCR } \alpha / \beta- \\
0.02,78 \times 10^{9} \\
( \pm 0.01)\end{array}$ & $\begin{array}{l}\text { TCR } \alpha / \beta-8,9 \\
\times 10^{9}( \pm 1,4)\end{array}$ \\
\hline Т-лимфоциты $\gamma \delta$ & $\begin{array}{l}\text { TCR } \gamma \delta-1,28 \times 10^{9} \\
( \pm 0.3)\end{array}$ & $\begin{array}{l}\text { TCR } \gamma \delta-1,1 \times 10^{9} \\
( \pm 0.3)\end{array}$ & $\begin{array}{l}\text { TCR } \gamma \delta-1,1 \times 10^{9} \\
( \pm 0.3)\end{array}$ & $\begin{array}{l}\text { TCR } \gamma \delta-1,0 \\
\mathrm{x} 10^{9}( \pm 0.01)\end{array}$ \\
\hline $\begin{array}{l}\text { Белок,корецептор, } \\
\text { расположенный на } \\
\text { поверхности В- } \\
\text { лимфоцитов }\end{array}$ & $\begin{array}{l}\text { CD19+ - } 16.4 \times 10^{9} \\
( \pm 4)\end{array}$ & $\begin{array}{l}\text { CD20+ }-16.1 \times 10^{9} \\
( \pm 4)\end{array}$ & $\begin{array}{l}\text { CD20+- } \\
0.01 \times 10^{6}( \pm 0.1)\end{array}$ & $\begin{array}{l}\text { CD20+ - } \\
0.01 \times 10^{6} \\
( \pm 0.1)\end{array}$ \\
\hline $\begin{array}{l}\text { мембранный } \\
\text { белок,молекула } \\
\text { межклеточной } \\
\text { адгезии }\end{array}$ & $\begin{array}{l}\text { CD34+ - 32.4x } 10^{6} \\
( \pm 6)\end{array}$ & $\begin{array}{l}\text { CD34+ - } 25.4 \times 10^{6} \\
( \pm 6)\end{array}$ & $\begin{array}{l}\text { CD34+- } \\
13.7 \times 10^{6}( \pm 3)\end{array}$ & $\begin{array}{l}\text { CD } 34+- \\
1,1 \times 10^{6}( \pm 0,2)\end{array}$ \\
\hline
\end{tabular}

Таблица 1. В данной таблице отражены обработка клеточного продукта согласно стандартного протокола. Результаты магнитной сепарации TCR $\alpha / \beta$ и CD19 клеток и проанализированы продукт сепарации отдельно.

Выводы: Таким образом, в нашем опыте полученный трансплантант при использовании технологии истощения TCR $\alpha / \beta$ и CD19 клеток соответствовал международным рекомендациям гаплоТГСК, а восстановление мегакариоцитарного и гранулоцитарного ростков у детей отмечались на $+15( \pm 4)$ день после ТГСК. 


\section{ЛИТЕРАТУРА}

1. «Деплеция альфа/бета-Т-лимфоцитов - надежная платформа для развития трансплантации гемопоэтических стволовых клеток от гаплоидентичных доноров»Текст научной статьи по специальности «Клиническая медицина». Автор: Масчан М.А [1:35-36].

2. «Индивидуализация гематопоэтической трансплантации стволовых клеток с использованием альфа/бета Т-клеточного истощения».2019г. Авторы:Эмели Радестад,Микаэль Сундин,Иоганн Тёрлан,Сара Тунберг,Бьорн Енфельт,Пер Люнман,и.т.д.

3. «Проведение гаплоидентичной трансплантации костного мозга (гапло-ТКМ) с использованием посттрансплантационного циклофосфана: опыт одного центра.» Дмитрий В. Моторин, Ренат Ш. Бадаев, Диана В. Бабенецкая, Наталья А. Ильина, Татьяна О. Силина, Георгий Г. Бараташвили,и.т.д. Северо-Западный Федеральный Медицинский Исследовательский Центр им. В.А. Алмазова. 


\title{
COMPUTER TOMOGRAPHY AND X-RAY DIAGNOSTICS OF PERIPHERAL PRIMITIVE NEUROEECTODERMAL TUMORS (PNET) IN CHILDREN.
}

\author{
Umid Ibragimov, Sundetilla Sargelov, Murat Ensepbaev, Amankul Taynekova, \\ Malika Inragimova
}

Scientific Center for Pediatrics and Pediatric Surgery. Kazakhstan, Email: inyo@yandex.ru

\begin{abstract}
Relevance: Peripheral primitive neuroectodermal tumor (PNET) belongs to the group of malignant tumors that develop from migrating embryonic neural crest cells. PNET includes a number of nosological forms: Askin's tumor, esthesioneuroblastoma, the very peripheral primitive neuroectodermal tumor, Ewing's sarcoma. PNET accounts for 3-9\% of all soft tissue tumors in children and $19 \%$ of all soft tissue sarcomas. In European countries and the United States, the frequency of their occurrence is 3.4 cases per year per 1 million children under 15 years of age, in Kazakhstan - 0.6-1.2 cases per 1 million child population. Rapid tumor growth, malignancy and early metastasis to other organs and systems predetermines its special role in oncology.

Objective of the study: to improve the quality and availability of early diagnosis of sarcomas in children in medical institutions of the general medical network.

Results of the study: 35 cases of peripheral PNET in children were analyzed. The age of the patients is from 1.5 to 17 years. The average age is 9.3 years. There were 1.3 times more boys among patients than girls. Extra-skeletal localization was found in one patient (3.6\%). Radiographically, it is often almost impossible to make a differential diagnosis between the manifestations of Ewing's sarcoma and primary chronic or "healed" (antibiotic) forms of acute hematogenous osteomyelitis in the initial phase of the process, before the formation of the extraosseous soft tissue component. The process of bone damage is more often localized in its diaphysis and subsequently spreads to the metaphyses of the bone.
\end{abstract}

Conclusion: PNET is more likely to come from the chest wall, so it is advisable to start the X-ray protocol with a chest X-ray. In terms of radiation semiotics, PNET is similar to Ewing's sarcoma and Askin's tumor, and therefore an additional immunohistochemical study of the drug is required. An important indirect diagnostic criterion is the predominance of the soft tissue component over the bone manifestations in Ewing's sarcoma. To clarify the extent of changes, accurate staging of the tumor and assess the dynamics of the tumor after treatment, extended CT and MRI studies with contrast enhancement (chest, abdominal cavity and pelvis, area of primary lesion), as well as skeletal scintigraphy are required. The above conclusions generally confirm the literature data.

Актуальность темы: Периферическая примитивная нейроэктодермальная опухоль (primitive neuroectodermal tumor - PNET) входит в группу злокачественных опухолей, развивающихся из мигрирующих эмбриональных клеток неврального гребешка. PNET — собирательный термин, который включает ряд нозологических форм: опухоль Аскина, эстезионейробластому, саму периферическую примитивную нейроэктодермальную опухоль, саркому Юинга, в том числе экстраоссальную саркому Юинга. 
Опухоли в области грудной клетки обычно описывают как опухоли Аскина.

PNET составляет 3-9\% всех опухолей мягких тканей у детей и 19\% всех мягкотканых сарком. В европейских странах и США частота их встречаемости составляет 3,4 на 1 миллион детей в возрасте младше 15 лет в год.

В Казахстане 0,6-1,2 случаев на 1 млн. населения. Быстрый рост опухоли, злокачественность и ранее метастазирование в другие органы и системы, предопределяет её особую роль в онкологии.

Саркома Юинга (Ewing's sarcoma)- злокачественная опухоль костного скелета, как правило, поражает нижнюю часть длинных трубчатых костей, ребра, таз, лопатку, позвоночник и ключицу.

В структуре заболеваемости среди злокачественных новообразований костей саркома Юинга занимает второе место после остеогенной саркомы, составляя 10-25\%. В год выявляется 0,61,5 новых случаев заболевания на 1 млн. детского населения.

Часто встречается в возрасте 10-15 лет. Пестрота клинической картины, чрезвычайная агрессивность с бурным гематогенным метастазированием в легкие и кости скелета, предопределяют ее особое место в практическом отношении.

Цель исследования: Изучить радиологическую картину саркомы Юинга у детей, госпитализированных в НЦП и ДХ в период 2015-2020 гг. с диагнозом: «PNET». Провести дифференциальную диагностику саркомы Юинга и остеогенной саркомы, а также проанализировать половозрастные характеристики заболевших детей.

Материалы и методы исследования: В основу работы положены данные радиологического исследования PNET у 35 пациентов в период с 2015-го по 2020 годы.

Всем пациентам выполнены рентгенограммы органов грудной клетки, а также мультиспиральная компьютерная томография грудной клетки, брюшной полости и зоны первичного поражения с контрастированием. Диагноз всегда подтверждался методом ИГХ.

Результаты исследования и их обсуждение: Мы проанализировали 35 случаев PNET у детей: болезнь исходила из стенки грудной клетки $(42,9 \%)$, плоских костей $(35,7 \%)$, длинных трубчатых костей $(14,2 \%)$, костей лицевого черепа $(3,6 \%)$, костей основания черепа $(3,6 \%)$. Метастатическое поражение часто присутствует на момент диагностики в легких, костях и костном мозге. Возраст пациентов - от 1,5 года до 17 лет. Средний возраст составил - 9,3 года. Мальчиков среди пациентов было в 1,3 раза больше, чем девочек. Внескелетная локализация была обнаружена у одного пациента $(3,6 \%)$.

Рентгенологическая картина саркомы Юинга имеет ряд характерных особенностей:

- наличие деструктивного и реактивного процессов костеобразования;

- мелко или среднеочаговая деструкция сливного характера в плоских костях, чередующаяся с зонами склероза и остеолиза (по типу «кости, изъеденной молью»); преобладание крупноочаговой деструкции при поражении костей таза;

- в подавляющем большинстве случаев присутствует мягкотканый компонент опухоли;

- склеротический тип опухоли встречается редко и характерно для плоских костей, ребер и метафизов трубчатых костей; 
- распространение процесса на кортикальный слой вызывает его разволокнение, расслоение, контуры его становятся неровными и нечеткими;

- распространение процесса под надкостницу стимулирует периостальное костеобразование;

- периостальная реакция, обычно пластинчатого (так называемый «луковичный периостит») или игольчатого (спикулообразного) типа, имеет место в половине наблюдений, особенно часто при локализации в диафизах и в костях таза;

- спикулы одинаковы по длине и толщине, ориентированы перпендикулярно поверхности кортикального слоя, прослеживаются на значительном протяжении пораженной кости и равномерно распределены вдоль диафиза.

Эти особенности позволяют осуществлять дифференциальный диагноз с остеогенной саркомой, для которой характерно:

- наличие грубых неравномерных по длине спикул, расходящихся как бы из одного центра;

- мягкотканый компонент опухоли имеется практически всегда и может прослеживаться на рентгенограммах, дополняя рентгенологическую картину этого новообразования.

По рентгенологической картине саркому Юинга следует дифференцировать с первичной лимфомой кости, миеломой, остеогенной саркомой, центральной хондросаркомой, эозинофильной гранулемой, остеомиелитом. Рентгенологически зачастую практически невозможно провести дифференциальную диагностику между проявлениями саркомы Юинга и первично-хроническими или «залеченными» (антибиотическими) формами острого гематогенного остеомиелита в начальной фазе процесса, до формирования внекостного мягкотканого компонента. Непременно следует уделять внимание клинической составляющей заболевания, так пик заболеваемости саркомой Юинга приходится на 10-15 лет, чаще болеют мальчики, преимущественно поражаются кости стенки грудной клетки и длинные трубчатые кости. Процесс поражения кости чаще локализуется в ее диафизах, и впоследствии распространяется на метафизы кости. Рентгенологически в большинстве случаев теряется четкость контура коркового слоя с возникновением очагов деструкции без некроза и секвестрации. Формирование спикул наблюдается у 20-30\% пациентов. Четко определяется локальная припухлость с максимальным увеличением размеров на уровне наиболее выраженной деструкции.

Выводы: Лучевые методы играют большую роль в выявлении опухоли и ее метастазов. По лучевой семиотике PNET схожа с саркомой Юинга и опухолью Аскина, и поэтому, дополнительно, требуется иммуногистохимическое исследование препарата. Немаловажным косвенным диагностическим критерием является преобладание мягкотканого компонента над костными проявлениями при саркоме Юинга. Для уточнения протяженности изменений, точного стадирования опухоли и оценки динамики опухоли после проводимого лечения необходимы расширенные КТ и МРТ исследования с контрастированием (грудная клетка, брюшная полость и таз, область первичного поражения), а также сцинтиграфия скелета. 


\section{ЛИТЕРАТУРА}

1. Веснин А. Г., Семенов И. И. Атлас лучевой диагностики опухолей опорнодвигательного аппарата: Часть 1: Опухоли скелета. - СПб.: Невский Диалект, 2002. C. 6 .

2. Рейнберг Самуил Аронович "Рентгенодиагностика заболеваний костей и суставов" . 1964г.

3. Barker L.M., Pendergrass T.D., Sanders J.E. et al. Survival after recurrence of Ewing's sarcoma family of tumors // J.Clin.Oncol. - 2005. - Vol.23. - P.4354. 2. 4. Bernstein M., Kovar H., Paulussen M. et al. Ewing's sarcoma family of tumors: current management // The Oncol. - 2006. - Vol.11(5). - P.503.

4. Dyck P, Parizel PM, De Schepper AM. Ewing's sarcoma: imaging features. JBR-BTR : organe de la Societe royale belge de radiologie (SRBR) = orgaan van de Koninklijke Belgische Vereniging voor Radiologie (KBVR). 2009 : 90(5): 368-76. Pubmed

5. Halperin EC. Pediatric radiation oncology. Lippincott Williams \& Wilkins. (2005) ISBN:0781742528.

6. Meyers SP. MRI of bone and soft tissue tumors and tumorlike lesions, differential diagnosis and atlas. Thieme Publishing Group. (2008) ISBN:3131354216.

7. Ewing J. Classics in oncology. Diffuse endothelioma of bone. James Ewing. Proceedings of the New York Pathological Society, 1921. CA Cancer J Clin. 22 (2): 95-8.

8. Стандарты оказания специализированной помощи детям и подросткам с гематологическими и онкологическими заболеваниями у детей и подростков. Медпрактика-М, Москва, 2009.

9. Руководство по химиотерапии опухолевых заболеваний , под редакцией Н.И.Переводчиковой, 2011. 


\title{
SECONDARY INFECTION IN CANCER PATIENTS OF THE MUSCULOSKELETAL SYSTEM
}

\author{
Ahliman Amiraslanov, Elnur Ibragimov, Sevinj Abdiyeva, Samira Qaraisayeva \\ Azerbaijan Medical University, Department of Oncology, Azerbaijan. \\ Email: tmr.azeri@yandex.ru
}

\begin{abstract}
Infectious diseases complications remain one of the main problems of surgery. Infections are one of the causes of canser patients morbidity and mortality, along with tumor diseases. The frequency of postoperative wound complications varies between 3-34\% depending on the type of surgery [5]. Cancer patients are more susceptible to the systematic immunosuppresive state, caused by malignant neoplasms and directly by antitumor therapy. It is obvious that the anticancer problem of treatment and prevention of secondary infections in these conditions becomes even more urgent than before.
\end{abstract}

Objective: To analise infections complications (IC) caused by microorganisms depending on antitumor treatment in cancer patients.

Materials and methods: The study included 41 (100\%) cancer patients with infectious complications during antitumor treatment in the Azerbaijan Medical University (AMU) Cancer clinic for skin and soft tissue neoplasms. Most often, the pathological process was lokalized in the lower extremities in $19(46 \%)$ patients; in the upper extremities in $14(34,1 \%)$ patients: in the trunk in 8 $(19,5 \%)$ patients. Of these 12 patients $(29,2 \%)$ patients received treatment for posteopertive complicattions, $10(24 \%)$ patients received treatment for complications - related to chemotherapy and $19(46 \%)$ patients received treatmentrelated to radiation therapy. There were $28(68 \%)$ men and 13 woman $(36,5 \%)$ patients. The age of the patients ranged from 34 to 82 years among the studied patients with soft tissue tumors $24(58 \%)$, skin tumors $17(41,4 \%)$ patients .

Results and discussions : for postoperative complications, the patients were divided by severity: uncomplicated - $12(100 \%)$ patients (mostly superficial, not reguiring extensive surgical interventios) and complicated- 0 patients- (involving superficial and deep structures, often requiring extensive surgical interventions). Early diagnosis of infectious complications in patients with this pathology, the appointment of adequate regimens of antibiotic prophylaxis and therapy contribute to reducing the level of mortality from infection in this category of patients, and the expanding possibilities of specific antitumor treatment.

In the pathogenesis of wound infections, highly virulent microorganisms that cause additional tissue damage and significantly slow down the regeneration of wounds are of primary importance.

Bacteriological studies performed in patients revealed a diverse microflora. Such microorganisms include S. aures $(82,5 \%)$, S. pyogenes (5,3\%). Paeruginosa enterococci and enterobacteria $(2 \%)$.

It should be noted that in chronic wounds a sign of infection and an indication for antibacterial therapy are the isolation of S.aureus and P. Eruginosa. S. aureus is the most common causative agent of surgical infection of skin and soft tissue. A very important point is the method of obtaining clinical material. Microbiological infection of the skin and soft tissues consists of studies of biological 
material obtained from the source of infections, as well as blood tests if generalization of the process is suspected.

Microscopy takes into account not only the morphology and quantitative ratio of individual microbes, but also the presence of leukocytes. Taking the material for research should be carried out as far as possible, before antibacterial therapy (ABT) [6].

The result of a cytological study allow us to objectify the idea of the course of the wound process in this category of patients with development of wound complications.

The presence of concomitant diseases deserves special attention. Skin and soft tissue infections are one of the most common nosocomial infections and are most often caused by gram-positive microorganisms (staphylococci, streptococci, enterococci) that are multidrug-resistant and gramnegative (proteus, klebsiella) microorganisms. Out of the 12 patients in those who used the developed methods of preventation and treatment seromas in $6(50 \%)$ patients, infiltrates were observed in 3 $(2,5 \%)$ cases. In patients on the $9^{\text {th }}-11^{\text {th }}$ day after surgary, day after surgery, the general condition of all patients was assessed as satisfactory. In 6 patients, there was seroma, which was eliminated by 34 short puncture. In $1(0,8 \%)$ case, there was a hematoma, that was successfully resolved using conservative methods. According to our data the temperature of the intact skin corresponded to $(34,04 \pm 0,01)$, close to the neutral $\mathrm{pH}$ value $(5,5)$ and this level was considered as the physiological norm. In $1(0,8 \%)$ abservation, soft tissue deficiency was accompanied by significant tension of the wound edges especially in eldely and senile patients, which led to the eruption of ligatures. After repeated operations in patients wound healing occurred by secondary tension, which caused the duration of treatment. All patients received antibacterial drugs to prevent infectious complications in the postoperative period. No suppuration of postoperative wounds was observed.

Local dosage forms with an antibacterial component occupy an important place in the treatment protocols for surgical infectious of the skin and soft tissues. Curently in the arsenal of doctors has a sufficient number of anti - infections and antibacterial drugs. Treatment included antibacterial, antiinflammatory infusion and immunostimulating therapy. Antibacterial therapy was perfomed taking into account the sensitivity of the microflora, local treatment of the wound with antiseptics (bandages 2-3 times) and then with ointment dressings. In the course of treatment, $100 \%$ of patients had microbe elimination by the end of the study (the wounds were sterile). However, even intensive antibacterial therapy is not effective enough if the patient has a significant suppression of the immune response.

Special attention should be paid to the presence of concomitant disease: Diabetes mellitus was observed in $21(51,2 \%)$ patients, myocardial infarction in $7(17 \%)$ patients, Hepatitis $\mathrm{C}$ in $4(0,9 \%)$ patients, Hepatitis B in $5(12,1 \%)$. Thalasemia in $3(0,7 \%)$ patients, breast cancer in $1(0,02 \%)$. It is shown that the presence of cancer itself is an independent risk factor for the development of wound infectious: the risk of infection in cancer patients is 3 times higher than in patients without cancer (74,1\% against $25,9 \%)$ [4] .

A special feature of patients in their high sensitivity to viral and bacterial infections due to physiological morphofunctional immaturity of the immune system and insufficient reserve capabilities (fig 1,2). 


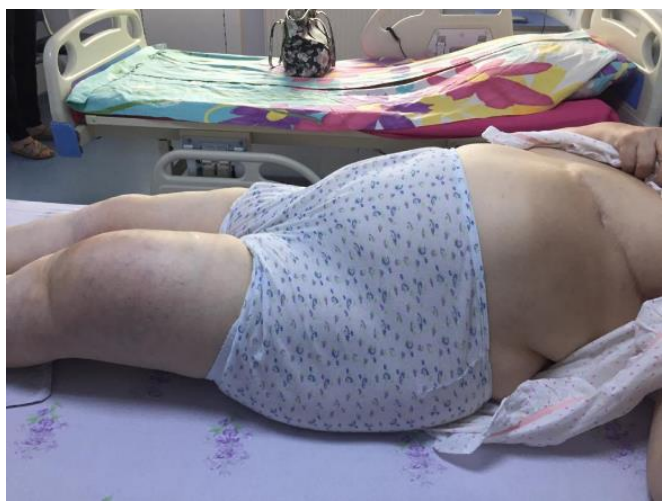

Figure 1 View before surgery. Tumor of the left thigh. History of the surgery for breast cancer.

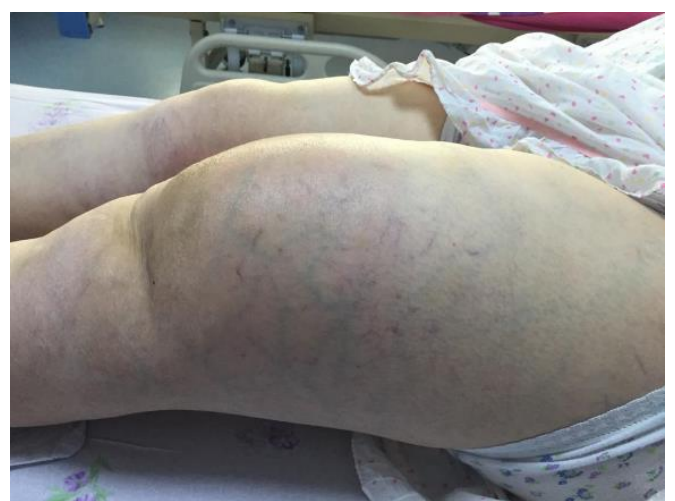

Figure 2 Tumor of the left thigh Soft tissue sarcoma of the left thigh.

Studies of patients immune status can reveal defects in auti-infective protection that lead to a violation of pathogen elimination and show down reparative processes $[1,2]$. The wound was healed by primary tension, and the patient was discharged home on the $9^{\text {th }}$ day (Figure 3 ) .

When exposed to a large field, immunosupression usually occurs. Immunosupression is a special long-term complication of radiation therapy.

During radiation therapy, the barrier function of irradiated tissues are regressed, and the number of immunocompetent cells in significantly reduced especially, when using acelerated fractionation modes. In this complication, radiation can significantly reduce the bodys ability to resist the development of infections. The development of infection in patients with burns is the result of violation of the skin barrier and normal microbiocenosis, wound ischemia, and depression. However, when the integrity of the epidermis is violate microorganisms overcome this barrier, which can lead to the development of infection violation of the integrity of the skin is a characteristic, but not mandatory symptom, this is the so - called "entrance gate" of infection (Fig 4). It should be noted that to prevent the invasion of flora from the skin, mucous use of antimicrobial drugs is recommended in order to reduce the risk of infection.
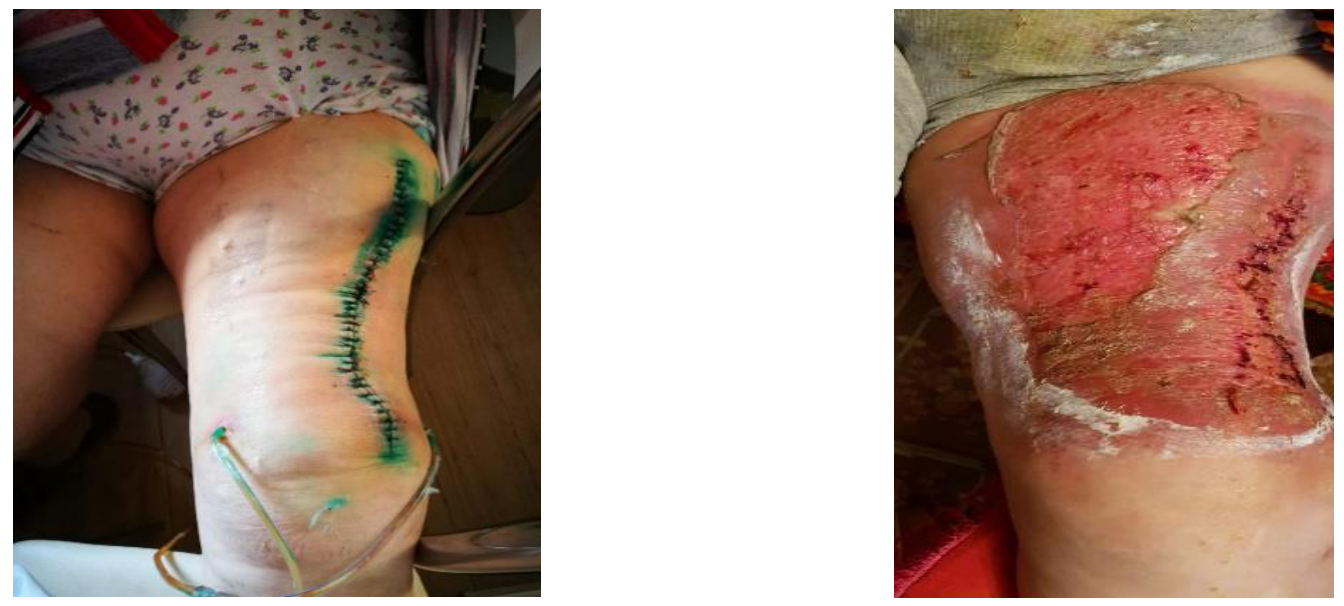


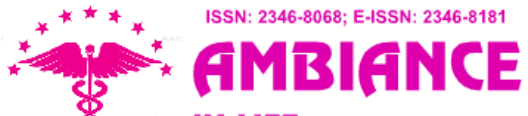

IN LIFE

INTERNATIONAL SCIENTIFIC JOURNAL IN MEDICINE

Figure 3 View after surgery.

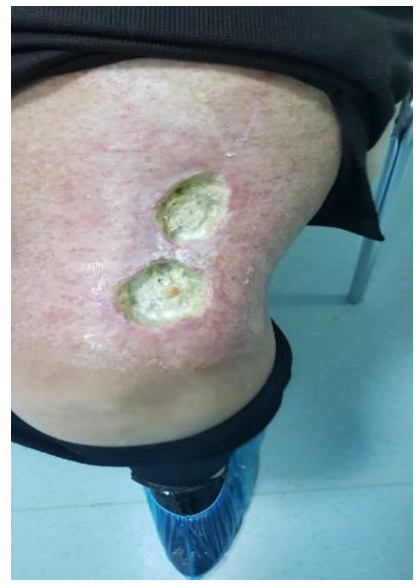

Figure 5 View before drain age.
Figure 4 View after radiation therapy.

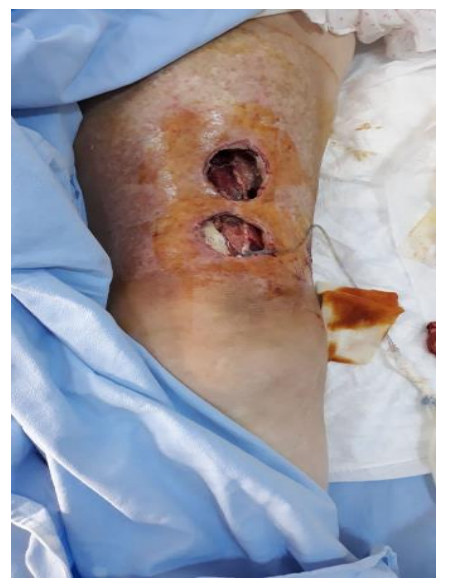

Figure 6 View after drainge.

In $1(0,8 \%)$ patient after radiation therapy due to complications the wound was drained (figures 5,6 ). Among all skin tumors squamous cell carsinoma is the second most common. (figure 7) [3]. The annual increase is $0,6 \%$. Bacteriological examination of biological materials revealed $17(100 \%)$ patients with skin cancer. Staphylococcus aureus 74\%, Streptococcus 10,5\%, S. pyogenes 4,5\%, Pseudomonos 2,3\%.

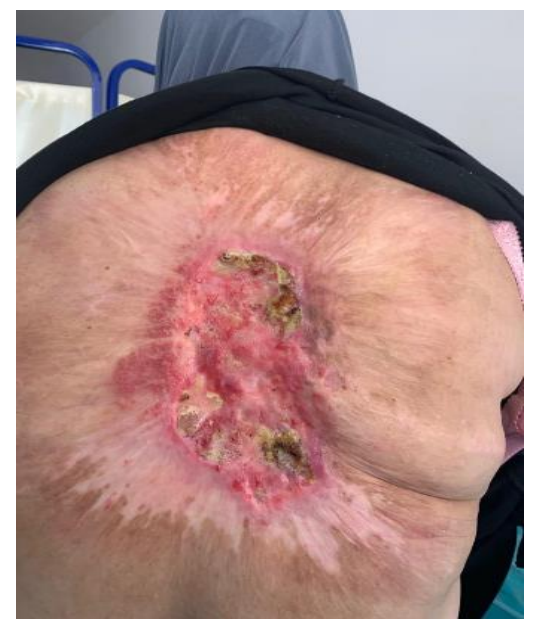

Figure 7 Squamous cell carsinoma of the skin.

Among the infectious caused by S. pyogenes in our studies they were most often detected in elderly patients. Cytological examination (100\%) revealed while blood cells neutrophils, fibroblasts, and inflammatoy elements.

Infections complications after chemotherapy can be divided into two main groups: true secondary infections and opportunistic infections. The first group includes those infectious whose pathogens entered the patients body during chemotherapy. This group of infectious can be considered 
intercurrent (secondary), since they are manifested in the treatment process. The second group consists of infectious that developed as a result of reactivation and clinical manifestation, whose pathogens latently persisted in the body before prior to chemoterapy. These include infections caused by ubiquitous viruses, primarily from the herpes family, as well as infections caused by opportunistic bacterial and fungi. These infections unite in a group of "opporttunistic" infections. Complications on the background of chemotherapy from to patients acute diarrhea in $7(0,8 \%), 1(0,1 \%)$ patient stomatitis, $2(0,2 \%)$ patients urinary tract cystitis. In cancer patients, acute diarrhea was caused by pathogenic instestinal microflora (enterotoxigenic Escherichia coli 67\%, Salmonella spp 13\%, Shigella spp 9\%, S Aureus 6\%. Due to immunosupressive therapy (corticosteroids, chemotherapy) the secretory function of the skin glands decreases, the regenerating activity of the epitelium increases the permeability of the skin to microorganisms. This problem is especially relevant for patients who are in deep neutropenia for a long time. In our study, there were no several forms of complications.

Infectious processes that complicate the course of cancer significantly worsen the condition and prognosis of patients. Along with this, purposeful conduct of further research, timely identification, effective treatment and prevention of secondary infections as an important part of the entire complex of medical and preventive measures carried out in clinics in this area,we consider very relevant.

\section{REFERENCES}

1. Пальцев М.А., Черепахина Н.Е, Шонфельд Е. и др. Постинфекционный клиникоиммунологический синдром: основы этиопатогенеза и стратегия иммуногенодиагностики// Вестник Российской АМН. -2009.-10.-С. 25-31.

2. Симонова А.В., Лебедева И.С. Инновационные методы диагностики и лечения вторичных иммунодефицитных состояний // Лечащий врач. -2012. -4. - С. 16-19.

3. Каприн А.Д., Старинский В.В., Петрова Г.В. Состояние онкологической помощи населению России в 2017 году. М.; ФГБУ «МНИОИ им. П.А.Герцена» Минздрав России; 2018:18.

4. Петухова И.Н Факторы риска хирургической инфекции. Общие вопросы профилактики хирургических инфекций //В кн.:» Послеоперационные инфекционные осложнения: диагностика, лечения, профилактика. Практическое руководство» под ред. Н.В.Дмитриевой, И.Н.Петуховой, 2013, Москва, «Практическая медицина», с 61-88.

5. Липатов К.В. Этиопатогенетические особенности хирургической инфекции мягких тканей/К.В.Липатов, Е.А.Стан, О.В.Введенская и соавт.// Хирург.-2013-№5.-С.48-54.

6. Stevens DL, Bisno AL, Chambers HF et al. Practice guidelines for the diagnosis and management of skin and soft tissue infections: 2014 update by the Infectious diseases Society of America. ULR: http// www.idsociety.org/. 


\title{
ACUTE DISSEMINATED ENCEPHALOMYELITIS IN A 5 YEARS OLD BOY, A CASE REPORT
}

\author{
${ }^{1}$ Learta Alili Ademi, ${ }^{2}$ Dr.Spec.Blerim Ademi \\ ${ }^{1}$ University clinic for pediatric diseases, department of neurology, MD, Skopje, North Macedonia \\ ${ }^{2}$ University clinic of neurology, MD, Skopje, North Macedonia \\ Email: ${ }^{1}$ Dr.learta.alili@gmail.com, ${ }^{2}$ Dr.blerim.ademi@gmail.com
}

\begin{abstract}
Acute disseminated encephalomyelitis (ADEM) is uncommon demyelinating disease of the central nervous system (CNS) usually following a viral infection or vaccination represented with combination of motor, sensory, visual and cognitive symptoms. In this paper is reported a case of a five years old boy who was diagnosed and finally labeled as ADEM. The case is presented through clinical features, diagnostic investigations, outcome and effective treatment.
\end{abstract}

Keywords: acute disseminated encephalomyelitis, white matter, multiple sclerosis, magnetic resonance imaging

Introduction:Acute disseminated encephalomyelitis (ADEM) is a multifocal autoimmune demyelinating disease of the CNS usually following a viral infection or vaccination. It is an uncommon poly-symptomatic disorder that manifests as an acute-onset encephalopathy associated with polyfocal neurologic deficits and is typically self-limiting. The disorder usually is represented with combination of motor, sensory, visual and cognitive symptoms. Sometimes because of to the clinical presentation, the diagnosis is a dilemma, due to which many studies may be done with no confirmed conclusion. In addition, there have always been and will be present debates regarding the diagnosis of ADEM due to different clinical presentations in different cases. More than $80 \%$ of cases are reported to occur in children under 10 years old with a slightly male predominance, and a mean age range of 5 to 8 years old. In approximately $57-92 \%$ of patients total recovery is reported to occur while in 4-30 \% is reported the persisting of residual focal neurologic deficits. Clinically and pathologically ADEM resembles Multiple sclerosis (MS).

Case report: We report a five years old boy who was admitted with acute onset of symptoms of weakness and pain in the lower limbs and backbone and difficulty to stand on his feet and inability of walking. The patient is a relatively healthy child with a regular immunization status and with no family history. There was a lack of febrile illness or vaccination prior to the present illness. On admission he was conscious, afebrile, hypotonic, and with gait disturbance. During neurological examination verbal and visual contact was established, cranial nerve examination revealed normal findings, muscular strength and tone was normal, tendon reflexes were preserved with a hyperactivity in the lower limbs and positive Babinski sign on both sides, superficial and deep sensibility were preserved and there were no meningeal signs. Laboratory evaluation and diagnostic procedures were performed. Initial laboratory tests such as CBC, CRP, basic metabolic panel, and liver panel revealed normal findings. Additional laboratory studies were done, all with normal findings. There was a positive Epstein-Barr virus (EBV) IgG and Cytomegalovirus (CMV) IgG serology. Pneumoslide test showed positive Mycoplasma pneumonia IgM. Fundoscopic examination and CT scan of the brain revealed normal findings. MRI of brain showed multiple hyperintense focal lesions in subcortical 
white matter in fronto-temporo-parietal region bilaterally and left occipital region in $\mathrm{T} 2$ weighted images and FLAIR (Figure 1,2,3 and 4).
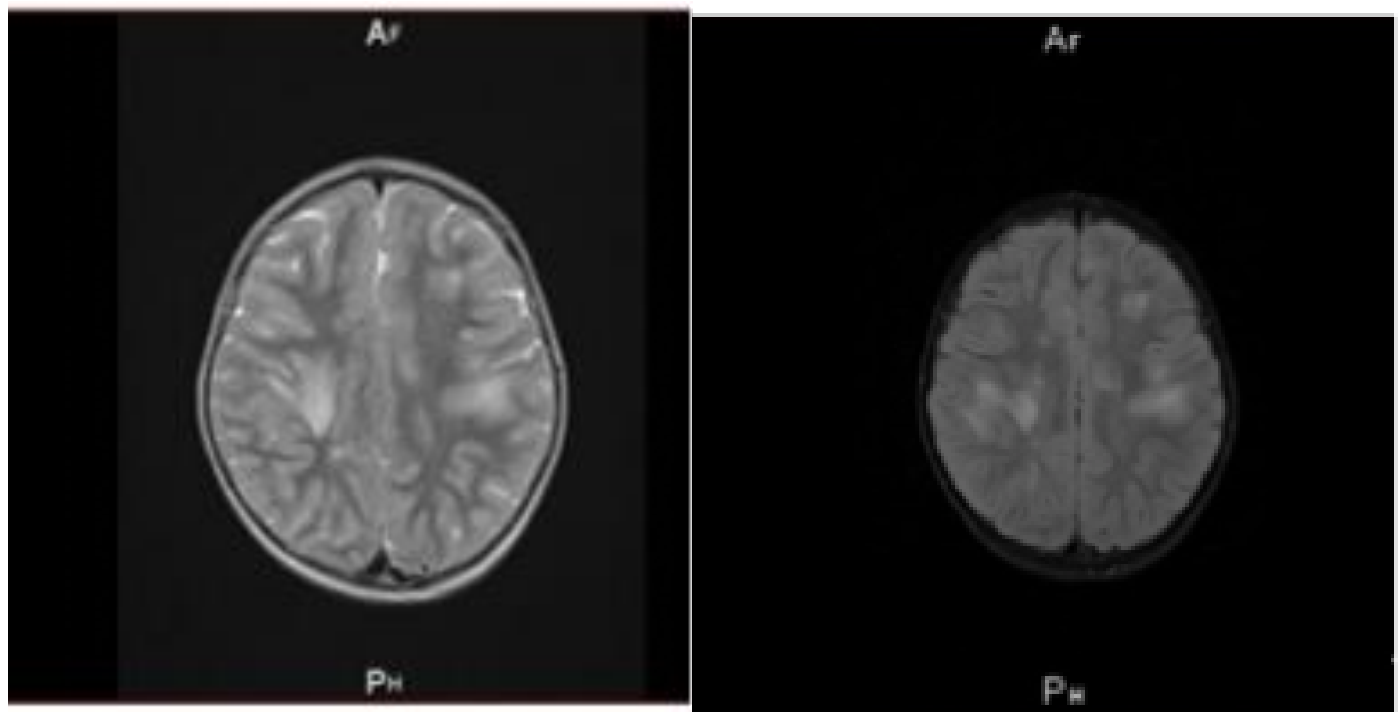

Figure 1 and Figure 2: Patient's brain MRI T2 weighted image sample
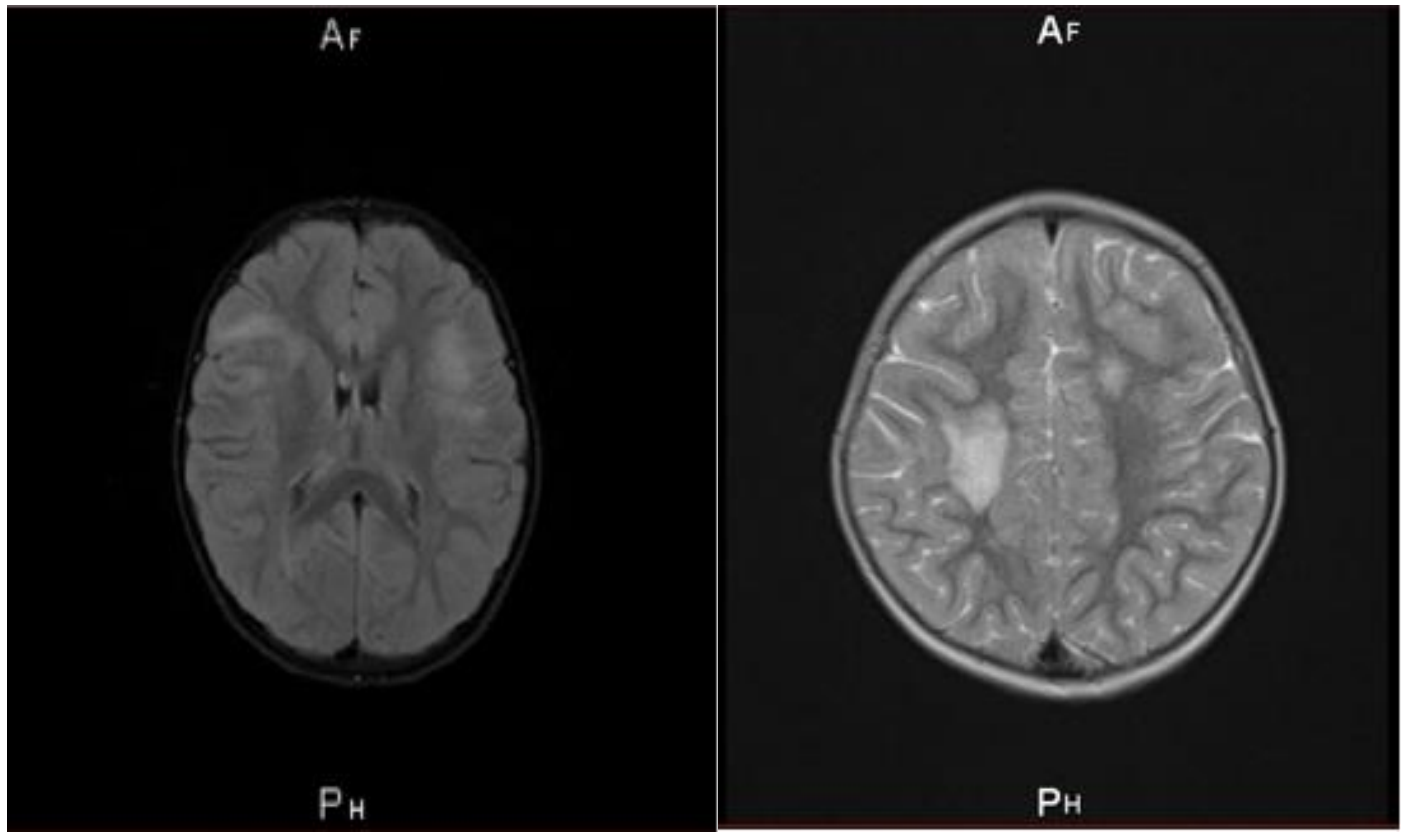

Figure 3 and Figure 4: Patient's brain MRI T2 weighted image sample 


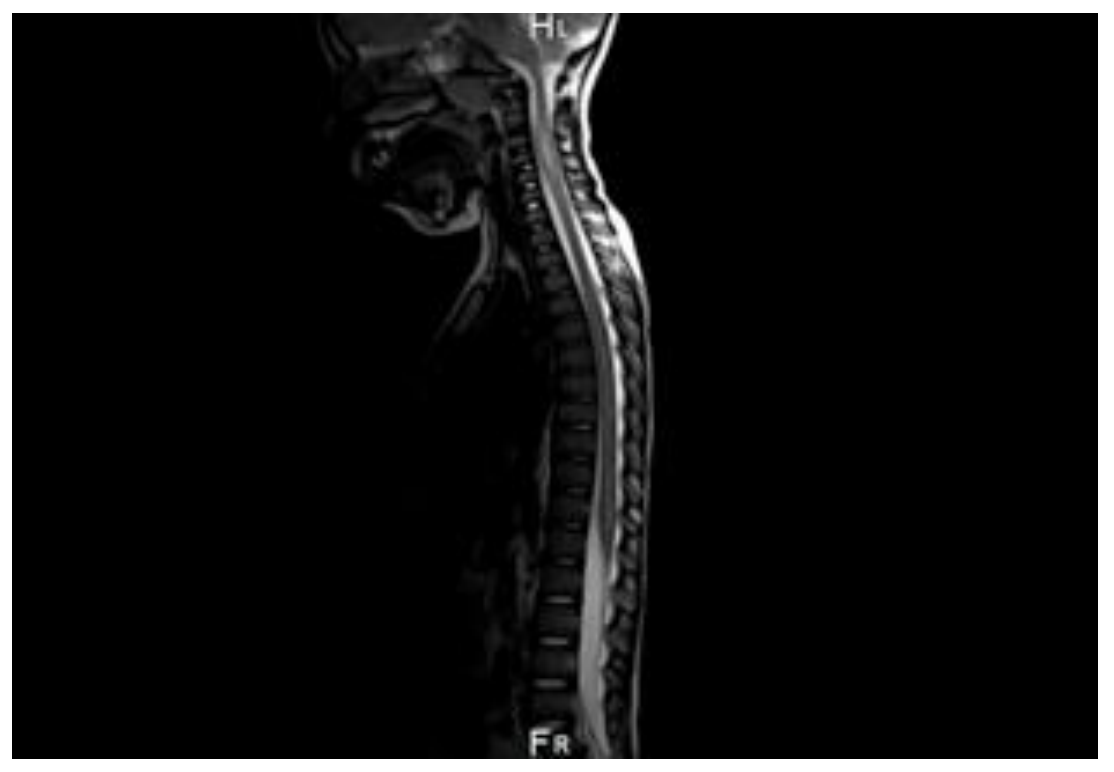

Figure 5 Patient's MRI of spinal cord T2 weighted image sample

MRI of spinal cord revealed hyperintense lesion in T2 weighted images from C2-C5 localized central with a widening of the central spinal canal upwards and downwards from the change (Figure 5).

EEG showed main activity of 7c/s and exhibited spikes of high amplitude in the right side some of which are spike wave complexes. Lumbar puncture was performed and cerebrospinal fluid (CSF) analysis showed CSF with normal pressure, lymphocytic pleocytosis and a glucose content of 2,81 $\mathrm{mmol} / \mathrm{l}$ (reference value $2.5-4.4 \mathrm{mmol} / \mathrm{l}$ ), protein content of $38,9 \mathrm{mg} / \mathrm{dl}$ (reference value $15-45$ $\mathrm{mg} / \mathrm{dl}$ ) and lactate of $1,6 \mathrm{mg} / \mathrm{dl}$ (reference value $<35 \mathrm{mg} / \mathrm{dl}$ ). Electrophoretic separation of CSF proteins showed a total proteins content of $0,39 \mathrm{~g} / \mathrm{l}$, albumin content of $226 \mathrm{mg} / \mathrm{l}$ and Immunoglobulin: $\mathrm{IgG}=25,6 \mathrm{mg} / \mathrm{l}$ with an $\mathrm{IgG}$ index of 0,42 and $\mathrm{IgG}$ synthesis in CNS was $0 \mathrm{mg} / 24$ $\mathrm{h}$, as seen in the Table 1 below. According to the characteristics of the electrophoregram there is an immunological activity in the brain that corresponds to an acute inflammatory process (Figure 6).

Table 1: Electrophoregram

\begin{tabular}{|l|l|l|}
\hline & Results & Reference value \\
\hline Total proteins $(\mathrm{g} / \mathrm{l})$ & 0,39 & $0,15-0,45$ \\
\hline Albumins $(\mathrm{mg} / \mathrm{l})$ & 226 & $50-250$ \\
\hline IgG $(\mathrm{mg} / \mathrm{l})$ & 25,6 & $3-30$ \\
\hline Albumin coefficient & 5,51 & $2,8-7,4$ \\
\hline IgG index & 0,42 & $<0,7$ \\
\hline IgG synthesis in CNS $(\mathrm{mg} / 24 \mathrm{~h})$ & 0 & $<5$ \\
\hline
\end{tabular}




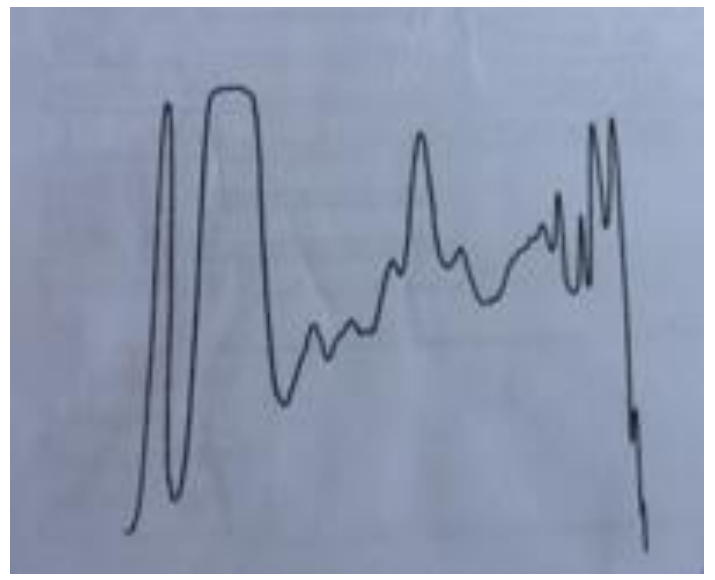

\section{Figure 6}

The clinical picture and the MRI scan findings as well as CSF lymphocytic pleocytosis were suggestive of ADEM. Treatment was implemented with high-dose intravenous corticosteroids (Methylprednisolone) with a dosage of $30 \mathrm{mg} / \mathrm{kg} / \mathrm{d}$ during 4 days. He made a dramatic improvement over the next few days and was able to walk well at the end of the first week.

Conclusion: Short duration of illness prior to admission, widespread multifocal involvement on MRI brain scan and the response to steroids favor the diagnosis of ADEM. CMV, EBV and Mycoplasma pneumoniae infections are associated with ADEM. CSF lymphocytic pleocytosis is a feature of ADEM. His CSF analysis, done during the recovery phase, showed 20 Lymphocytes and a protein content of $39 \mathrm{mg} / \mathrm{dl}$. The type of electrophoregram of cerebrospinal fluid is a gamma globulin type, also favoring the diagnosis of ADEM. MRI brain scan is the investigation of choice that shows high intensity lesions on T2WIs most commonly in the subcortical white matter. However, there are no generally accepted diagnostic criteria for ADEM. The predominant white matter involvement suggests demyelination, which is the hallmark of the disease. Bilateral subcortical white matter involvement on MRI brain scan is typical of ADEM, while 98\% of MS cases show periventricular white matter involvement, which was not seen in this patient. Even though, distinguishing ADEM from MS with a single MRI brain scan is impossible, first episode of MS needs to be taken in consideration.

\section{REFERENCES}

1. Alper G, Heyman R, Wang L. (2009) Multiple sclerosis and acute disseminated encephalomyelitis diagnosed in children after long-term follow-up: comparison of presenting features. Dev Med Child Neurol. 51(6):480-6.

2. Alper G. (2012) Acute disseminated encephalomyelitis. J Child Neurol.27(11):1408 25.

3. Anlar B, Basaran C, Kose G, Guven A, Haspolat S, Yakut A, et al. (2003) Acute disseminated encephalomyelitis in children: outcome and prognosis. Neuropediatrics 34(4): 194-9

4. Apak RA, Kose G, Anlar B, et al. (1999) Acute disseminated encephalomyelitis in childhood: report of 10 cases. J Child Neurol. 14(3):198-201. 
5. Banwell B, Kennedy J, Sadovnick D, Arnold DL, Magalhaes S, Wambera K, et al. (2009) Incidence of acquired demyelination of the CNS in Canadian children. Neurology. 72(3): 232-9.

6. Baum PA, Barkovich AJ, Koch TK, Berg BO. (1994) Deep gray matter involvement in children with acute disseminated encephalomyelitis. AJNR Am J Neuroradiol. 15(7):1275-83.

7. Callen DJ, Shroff MM, Branson HM, Li DK, Lotze T, Stephens D, et al. (2009) Role of MRI in the differentiation of ADEM from MS in children. Neurology. 72(11):968-73.

8. Dale RC, Branson JA. (2005) Acute disseminated encephalomyelitis or multiple sclerosis: can the initial presentation help in establishing a correct diagnosis? Arch Dis Child.. 90(6):636-9.

9. Dale RC, de Sousa C, Chong WK, Cox TC, Harding B, Neville BG. (2000) Acute disseminated encephalomyelitis, multiphasic disseminated encephalomyelitis and multiple sclerosis in children. Brain. 123 Pt 12:2407-22.

10. Dale RC. (2003) Acute disseminated encephalomyelitis. Semin Pediatr Infect Dis. 14(2):90-5.

11. Garg RK(2003)Acute disseminated encephalomyelitis. Postgrad Med J. 79(927):11-7.

12. Honkaniemi J, Dastidar P, Kähärä V, Haapasalo H. (2001) Delayed MR imaging changes in acute disseminated encephalomyelitis. AJNR Am J Neuroradiol. 22(6):1117-24.

13. Hung KL, Liao HT, Tsai ML. The spectrum of postinfectious encephalomyelitis. Brain Dev. 2001 Mar. 23(1):42-5.

14. Hynson JL, Kornberg AJ, Coleman LT, Shield L, Harvey AS, Kean MJ. (2001) Clinical and neuroradiologic features of acute disseminated encephalomyelitis in children. Neurology. 56(10):1308-12

15. Idrissova ZhR, Boldyreva MN, Dekonenko EP, Malishev NA, Leontyeva IY, Martinenko IN, et al. (2003) Acute disseminated encephalomyelitis in children: clinical features and HLA-DR linkage. Eur J Neurol. 10(5): 537-46

16. John L, Khaleeli AA, Larner AJ. (2003) Acute disseminated encephalomyelitis: a riddle wrapped in a mystery inside an enigma. Int J Clin Pract. 57(3):235-7.

17. K Ritarwan et al (2018) IOP Conf. Ser.: Earth Environ. Sci. 125012212

18. Kesselring J, Miller DH, Robb SA, Kendall BE, Moseley IF, Kingsley D, et al. (1990) Acute disseminated encephalomyelitis. MRI findings and the distinction from multiple sclerosis. Brain. 113 (Pt 2):291-302.

19. Kleiman M, Brunquell P. (1995) Acute disseminated encephalomyelitis: response to intravenous immunoglobulin. J Child Neurol. 10(6): 481-3.

20. Kumar, Rajesh and Brohi, Hazim (2016) "Adem, diagnostic dilemma, a tertiary care hospital experience:" Pakistan Journal of Neurological Sciences (PJNS): Vol. 11: Iss. 3, Article 8.

21. Leake JA, Albani S, Kao AS, Senac MO, Billman GF, Nespeca MP, et al. (2004) Acute disseminated encephalomyelitis in childhood: epidemiologic, clinical and laboratory features. Pediatr Infect Dis J. 23(8):756-64.

22. Mariotti P, Batocchi AP, Colosimo C,et al.(2003) Multiphasic demyelinating disease involving central and peripheral nervous system in a child. Neurology. 60(2):348-9.

23. McKeon A, Lennon VA, Lotze T, Tenenbaum S, Ness JM, Rensel M, et al. (2008) CNS aquaporin-4 autoimmunity in children. Neurology 71(2): 93-100

24. Mikaeloff Y, Suissa S, Vallée L, Lubetzki C, Ponsot G, Confavreux C, et al. (2004) First episode of acute CNS inflammatory demyelination in childhood: prognostic factors for multiple sclerosis and disability. J Pediatr. 144(2): 246-52.

25. Murthy JM. (2002) Acute disseminated encephalomyelitis. Neurol India. 50(3):238-43. 
26. Murthy SN, Faden HS, Cohen ME, Bakshi R. (2002) Acute disseminated encephalomyelitis in children. Pediatrics. 110 (2 Pt 1): e21

27. Noorbakhsh F, Johnson RT, Emery D, Power C. (2008) Acute disseminated encephalomyelitis: clinical and pathogenesis features. Neurol Clin. 26(3):759-80, ix

28. Oksuzler YF, Cakmakci H, Kurul S, et al. (2005) Diagnostic value of diffusion-weighted magnetic resonance imaging in pediatric cerebral diseases. Pediatr Neurol. 32(5):325-33.

29. Pena JA, Montiel-Nava C, Hernandez F, et al. (2002) Disseminated acute encephalomyelitis in children. Rev Neurol. 34(2):163-8.

30. Rust RS, Dodson WE, Trotter JL. (1988) Cerebrospinal fluid IgG in childhood: the establishment of reference values. Ann Neurol. 23(4):406-10.

31. Rust RS, Mathisen J, Prensky AL, et al. (1989) Acute disseminated encephalomyelitis (ADE) and childhood multiple sclerosis (MS). Ann Neurol. 26:467.

32. Rust RS. (2000) Multiple sclerosis, acute disseminated encephalomyelitis, and related conditions.Semin Pediatr Neurol. 7(2): 66-90

33. Sunnerhagen KS, Johansson K, Ekholm S. (2003) Rehabilitation problems after acute disseminated encephalomyelitis: four cases. J Rehabil Med. 35(1):20-5

34. Tenembaum S, Chamoles N, Fejerman N. (2002) Acute disseminated encephalomyelitis: a long-term follow-up study of 84 pediatric patients. Neurology. 59(8):1224-31.

35. Tenembaum S, Chamoles N. (1995) Acute disseminated encephalomyelitis: a longterm follow-up study of 84 pediatric patients. J Neurol Neurosurg Psychiatr. 58(4):467-470.

36. Tenembaum S, Chitnis T, Ness J, Hahn JS. (2007) Acute disseminated encephalomyelitis. Neurology. 68(suppl 2): S23-S36.

37. Trotter JL, Rust RS.(1989) Human cerebrospinal fluid immunology. In: Herndon RM, Brumback RA, eds. The Cerebrospinal Fluid. Boston, Mass: Kluwer Academic Publishers. 1989:179-226.

38. Weng WC, Peng SS, Lee WT, et al. Acute disseminated encephalomyelitis in children: one medical center experience. (2006) Acta Paediatr Taiwan. 47(2):67-71.

39. Wingerchuk DM. (2006) The clinical course of acute disseminated encephalomyelitis. Neurol Res. 28(3):341-7. 


\section{R761H M694I, M694V, V726A, R202Q, M680I AND E148Q MEFV GENE (FAMILIAL MEDITERRANEAN FEVER GENE) MUTATIONS IN THE AZERBAIJANIAN PATIENTS}

\section{Huseynova Lala, Huseynova Qumru}

Azerbaijan Medical University, Department of Medical biology and genetics. Senior teacher ${ }^{1}$. Azerbaijan

MEFV gene (Familial Mediterranean Fever Gene) is located on chromosome 16 - 16.13.3., and it is composed of 3,242,028-3,256,776 nucleotides. It is specified as having an autosome-recessive hereditary type. Autosome-dominant hereditary species were also recorded $(2,4)$.

The MEFV RoRet genes family contains exon 10, consisting of 10,000 nucleotide sequences(5). The length of the transcript consists of 3.7 thousand nucleotide sequences consisting of 761 synthesized pyridine protein amino acid bases $(1,3)$

MEFV gene researches were performed in the population of the Republic of Azerbaijan. Over 80 mutations have been identified so far. Four missense mutations (M680I, M694V, M694I, and V726A) in exon 10, together with E148Q in exon 2, account for the majority of FMF mutations in populations originating from areas around the eastern Mediterranean region. The various combinations of MEFV mutations are largely associated with the phenotypic variability of the disease. The most serious complication of FMF is the development of renal amyloidosis, which may be the only manifestation of the disease. The molecular-genetic study of the MEFV gene isolated from the genome DNA of 18 patients suspected of Family Disease Fever has identified 7 mutations: R761H M694I, M694V, V726A, R202Q, M680I and E148Q.

All patients were of Azerbaijan origin, from the Mediterranean region of Azerbaijan. They were evaluated for clinical findings and family history of FMF.

Seven mutations of MEFV gene were identified in heterozygous, homozygous and compound conditions: R761H M694I, M694V, V726A, R202Q, M680I and E148Q. The mutations E148Q and R202Q were discovered in exon 2 and R761H M694I, M694V, V726A, M680I were found in exon10 in the population of the Republic of Azerbaijan.

Three of 18 examined patients were heterozygotes, eight homozygotes, and seven double heterozygotes (compounds). Two mutations R202Q and E148Q were found in exon $2(28.57 \%)$ of the MEFV gene, but the remaining five mutations, M860I, R761H, M694I, M694V and V726A were located in the exon 10 of the gene (71.43\%). R202Q mutation was found in two heterozygous patients, mutation E148Q was heterozygous in one patient and as compound in two patients (R202Q /E148Q).

The homozygous form of $\mathrm{R} 761 \mathrm{H}$ mutation was registered in four cases, and M694I mutation in two persons in compound state (R761H / M694I). M680I mutation was identified to be homozygous in two patients (M680I / M680I).

The M694I mutation was found in compound state separately with two other mutations as M694V and R202Q (M694I/ M694V and M694I / R202Q).

The mutation of the V726A was identified as homozygous in three cases. It should be noted, that patients with homozygous form of mutations had parents in consanguineous marriages.

The highest gene frequency of the MEFV gene examined in 18 patients was $27.3 \%$ which belongs to $\mathrm{R} 761 \mathrm{H}$ mutation. The second place takes mutation V726A (18.2\%), and M694I (15.2\%) stands in the third place. 
To prevent the hereditary disease of the Family of Mediterranean Fever, parents of 18 patients were invited to the consultation of physician-genetics. Parents have got information about a healthy child prognosis for the next pregnancy. When the inheritance type is autosomal-recessive, it has been reported that the risk of a childbirth in the next pregnancy is $25 \%$. As the majority of families are in reproductive age, they are preparing for the prenatal diagnosis of the fetus in the next pregnancy with their consent.

Keywords: gene, population, sequencing, nucleotide, amplification, exon

\section{REFERENCE}

1. Sayın Kocakap D.B, Günel-Özcan A, Çabuk F, Ensari C. The frequency of Familial Mediterranean fever gene mutations and genotypes at Kirikkale and comparison with the mean of regional MEFV mutation frequency of Turkey. Mol Biol Rep. 2014;41(3):141926. View ArticlePubMedGoogle Scholar

2. Shinar Y, Obici L, Aksentijevich I, Bennetts B, Austrup F, Ceccherini I, et al. Guidelines for the genetic diagnosis of hereditary recurrent fevers. Ann Rheum Dis. 2012;71(10):1599605. View ArticlePubMedPubMed CentralGoogle Scholar

3. Topaloglu R, Ozaltin F, Yilmaz E, Ozen S, Balci B, Besbas N, et al. E148Q is a diseasecausing MEFV mutation: a phenotypic evaluation in patients with familial Mediterranean fever. Ann Rheum Dis. 2005;64:750-2.View ArticlePubMedGoogle Scholar

4. Yazici A, Cefle A, Savli H. The frequency of MEFV gene mutations in Behcet's disease and their relation with clinical findings. Rheumatol Int. 2012;32(10):3025-30.View ArticlePubMedGoogle Scholar

5. Yildırım B, Tuncer C, Kan D, Tunc B, Demirag MD, Ferda Percin E, et al. MEFV gene mutations and its impact on the clinical course in ulcerative colitis patients. Rheumatol Int. 2011;31(7):859-64.View ArticlePubMedGoogle Scholar 


\section{MEDICAL SUPPORT IN THE SAFETY SYSTEM OF NAVIGATION OF THE MODERN CIVIL MARINE}

\section{Simuzar Hajizade}

Azerbaijan Railway Closed Joint-Stock Company Baku Railway Polyclinic No.1, Deputy Chief Physician, Ministry of Health of the Republic of Azerbaijan, PhD student of Azerbaijan State Institute for the Improvement of Physicians named after Aziz Aliyev.Azerbaijan. Email: ehm@rambler.ru

Modernization of long-distance vessels, a decrease in the number of crews of ships, an increase in psycho-emotional stress, insufficient monitoring of compliance with safety and industrial hygiene requirements in the context of the transformation of the socio-economic way of life and the commercialization of the merchant marine fleet contribute to a decrease in the safety of navigation and an increase in the risk of consequences of adverse shifts in the health of seafarers long voyage. Studies have established that the specific conditions of long-term sailing contribute to the emergence and development of a wide range of neuropsychic and psychosomatic disorders, which is directly related to the causes of accidents at sea, the transition of highly qualified specialists to coastal work and the occurrence of severe chronic diseases in sailors. The variety and complexity of working conditions on long-distance vessels dictates the need to develop preventive and rehabilitative measures, taking into account the specifics of various types of work in the sea fleet. But until now, the scientific principles of preventive measures have not been formulated, requiring a systematic approach to protecting the health of the ship's personnel with the setting of specific and specific tasks in each period of production activity: on the shore and at sea.

In connection with the search for the necessary modernization of the prophylactic medical examination system for long-distance sailors, the transformation of the entire medical service, the development of constructive measures and proposals for their implementation in the new economic conditions are in practice one of the urgent problems of ensuring the safety of navigation, which requires its scientific justification.

The urgent need to preserve and strengthen the health of seafarers, as the main element of ensuring the safety of life of ships, determined the choice of the goal and objectives of this study.

The purpose of the study was to substantiate and scientifically develop a system of medical and organizational measures as factors contributing to an increase in the safety of life of ship ships of the transport fleet.

The objective of the study was to analyze the international requirements for ensuring the safety of life of ships related to the health of seafarers; to present the general principles of the professional suitability of seafarers related to their health and the organization of dispensary observation of seafarers as one of the most important elements of maintaining the safety of life of long-distance vessels; to study domestic and foreign experience in creating information technologies for organizing medical examination and assessing the quality of medical and preventive care for seafarers of long voyages; analyze the results and quality of preventive medical examinations of seafarers of longdistance voyages in order to determine the degree of their readiness to perform professional functions and outline ways to improve them; to assess the volume and quality of medical examination of seafarers of long-distance navigation; to develop a concept for increasing the efficiency of prophylactic medical examination of seafarers in the context of reforming the health care system of 
seafarers; to develop and test a comprehensive system of measures to ensure the prevention of violations of the safety of life of ships associated with deteriorating health and reduced working capacity of seafarers.

A literature review was carried out, a plan was drawn up and a program was developed, a medicalsociological, statistical and expert study was carried out (90\% contribution). The collection of scientific information was personally carried out by copying data from primary medical and regulatory documents and a questionnaire survey of cadets and seafarers of long-distance navigation ( $95 \%$ contribution), its analysis was carried out (95\% contribution).

The scientific novelty of the research lies in the fact that for the first time, from the standpoint of system analysis, a comprehensive analysis of the state of medical examination and medical support as factors of the life safety of long-range vessels has been carried out. On the basis of new methodological approaches with carrying out a differentiated clinical examination of seafarers of long voyages (anamnestic questionnaire survey of seafarers and the unification of commissions for medical examination of seafarers with a single computer connection), the main directions of improving the medical examination of seafarers in modern socio-economic conditions (the continuity of all links involved in the process of medical examination of seafarers: ship medical personnel, persons responsible for providing first aid and caring for the sick and injured, specialists of the commissions for medical examination of the ship's personnel and district medical centers).

The data based on the research results can become the basis for improving the sectoral preventive medical service in the regions of Azerbaijan, planning outpatient and inpatient care, the professional activities of ship doctors and those responsible for medical support.

Key words: Medical support, safety system, navigation of the modern civil marine

\section{References}

1. Baker M. Patient care (empowerment): the view from a national Society // Brit. Med. j. 2000. - № 7250. - P. 1660-1662.

2. Elliott M., Coventry A., Critical care: the eight vital signs of patient monitoring, British Journal of Nursing, 10.12968/bjon.2012.21.10.621, 21, 10, P.621-625, 2012.

3. Patterson P., Hons B.S., Psych M. Weed Analysis of a cancer education Program in South Westers Sydney // Cancer Nursing 2000. - Vol. 23, № 3. -P. 186-191.

4. Recio-Saucedo A., Maruotti A., Griffiths P., Smith B., Meredith P., Westwood G., Fogg C., Schmidt P., Relationships between healthcare staff characteristics and the conduct of vital signs observations at night: Results of a survey and factor analysis, Nursing Open, 10.1002/nop2.179, 5, 4, P.621-633, 2018.

5. Watson S. Interdisciplinary learning in Health care Education: who benefits? // Assighment 1999. - Vol. 5, № 1. - P. 23-26. 


\title{
MORPHOFUNCINAL CHARACTERISTIC OF THYMUS IN SEVEN MONTHLY RATS UNDER CONDITIONS OF MOUNTAIN HYPOXIA OF KYRGYZSTAN
}

\author{
Tamara Abaeva \\ Kyrgyz state medical academy named after I. K. Akhunbaev, Kyrgyzstan \\ Email: tamarakgma@mail.ru
}

\begin{abstract}
In recent years, the problem of hypoxia has attracted increasing attention of experimenters and clinicians, since studying various aspects of hypoxia has shown the universal role of short-term or longer-term oxygen deficiency in the regulation of body activity and the development of pathology. The most populated are the regions located in the low mountains (from 200 to $1400 \mathrm{~m}$ above sea level) and the middle mountains (from 1400 to $2500 \mathrm{~m}$ ). The highlands fall on a height of up to 3200 $\mathrm{m}$. Above is a non-residential snow highlands and above the highlands. A study of the histology of thymus was carried out in 62 seven-month-old rats living in various environmental and climatic conditions in Kyrgyzstan. Morphofunctional structures of the thymus gland in seven monthly rats were studied. Study methods: 1. Anatomical methods (preparation). 2. Histological methods (hemotoxylin-eosin coloring, according to Van Gizon). As a result of a study of seven monthly rats in Bishkek (770 m above sea level) under low-altitude conditions, all control group values are within normal limits. Indicators in Tuya-Ashu in the highlands (3200 $\mathrm{m}$ above sea level), a noticeable change in cells, for example, the number of lymphoblast indicators has increased. In the conditions of the middle mountain Cholpon-Ata (1660 m above sea level), cell performance decreased. The results of this study of seven monthly rats in the conditions of the highlands of Naryn (2000 m above sea level), the dynamics of cell populations in the unit of the conditional area of the cortical substance of the timus slice in tseven monthly rats showed a slight decrease in cell performance compared to the average Cholpon-Ata. Thus, Bishkek in low-altitude conditions, i.e. $770 \mathrm{~m}$ above sea level, all indicators of the control group are within the norm. In the highlands (3200 $\mathrm{m}$ above sea level), a noticeable change in cells, for example, the number of lymphoblasts increased by $3.44 \%$, average lymphacites increased by $2.03 \%$, small lymphacites by $316.8 \%$. Apoptotic bodies $59.8 \%$, mitoses by $2.1 \%$, Taurus Gassal increased by $0.09 \%$. Macrophage index increased by $0.12 \%$. Stereometric characteristic of crustal thymus substance of seven monthly rats $26.67 \%$. The cerebral matter increased by $6.99 \%$., The intra-pulmonary perivascular space (runway) by $1.66 \%$. Interdigital septs increased by $7.98 \%$.
\end{abstract}

Keywords: Timus. seven-month-old rats. Lowland, Midland and Highlands

Introduction: Currently, there is no doubt that in the complex response of the human body and animals to the effects of hypoxia, the immune system also has a role. According to the definition of numerous authors, the immune system, which plays a key role in ensuring the genetic constancy of the internal environment of the body, is a complex, multicomponent and self-regulating system under the control of neurogumoral regulation $[1,2,8,9,11]$. In this regard, it can be stated that immunology of adaptation process and study of its mechanisms in conditions of hypoxia is one of the main tasks of ecological immunology, the subject of which is study of changes of immunoreactivity under action of environmental factors $[2,3,4,10]$. The human body has wide possibilities for adapting to 
environmental conditions, which are ensured by the physiological reserves of the body. Kyrgyzstan is a mountainous country. Three quarters of its entire territory is located at an altitude of 1700-2800 m and above sea level, where a significant part of the population of the republic lives (with a population of 6 million people, more than $60 \%$ of the population live in mountainous areas, (according to the National State Committee, 2013), whose constant life takes place against the background of a different level of functioning physiological systems. In the highlands, the human body is affected by many adverse factors (low atmospheric and partial oxygen pressure, high intensity of sunlight and ultraviolet radiation, sharp temperature differences, changes in the ionic composition of air, and others), but the main, most significant of them is hypoxia. Factors of the highlands cause a state of stress in the human body, manifested both by the mobilization of compensatory and adaptive mechanisms, and by the development of pathological morphofunctional changes in various systems. Due to the long-term adaptation, the human body adapts to the mountain climatic conditions, acquires the ability not only to live, but also to actively work, performing hard physical work $[1,5,6,7]$. The problem of adapting the body to extreme effects, including oxygen starvation, will always be the focus of researchers of various profiles, since oxygen deficiency in one form or another accompanies a person throughout the life cycle. An even more pressing problem of adaptation to hypoxia is acquired due to the fact that human activities create specific situations that create the danger of changing the gas habitat $[3,8,11]$.

The aim of the present study is to study the morphofunctional structures of the thyroid gland in seven monthly rats.

Material and methods of research: A study of the histology of thymus in 62 seven-month-old rats living in various environmental and climatic conditions of Kyrgyzstan was carried out.

1.Anatomic methods (preparation). Under a binocular magnifying glass of MBS-2 allocated and cleaned тимус from surrounding fabrics.2. Histologic methods (coloring by gemotoksilin-eosine, according to Van-Gizon).

Own results and discussion: It was established during the autopsy that thymus in seven monthly rats of small size, soft consistency, its surface is lobed.

The rats gland is a small organ of pinkish - gray color, of soft consistency, its surface is lobed. The cortical layer contains a large number of lymphoid cells located very closely. Lymphoblasts are found along the periphery of the cortical layer, under the capsule. There are also many lymphoid elements in the medullar layer, but significantly less than in the cortical layer. In the medullar layer between cell elements is blood. In some places, epithelial-like cells and Gassal bodies are found in cortical layers. In individual slices, Gassal's bodies are not at all.

Bishkek in low-altitude conditions, i.e. $770 \mathrm{~m}$ above sea level, all indicators of the control group are within the norm. Indicators in Bishkek have been established, lymphoblasts average $14.5 \pm 0.4$; average lymphocytes $13.3 \pm 0.3$; small lymphocytes $166.4 \pm 1.1$; apoptotic bodies $77.8 \pm 0.5$; Mitoses $12.4 \pm 0.3$; Gassal's body is $1.7 \pm 0.2$. The stereometric characteristic of thymus in seven monthly rats shows: cortical parts $41.1 \pm 0.4$, medullar parts is $24.7 \pm 0.3$. Intra perivascular space (runway) $12.3 \pm$ 0.3 . Interstitial septs are $22.8 \pm 0.4$ (Fig. 1-5).

In the highlands (3200 $\mathrm{m}$ above sea level), a noticeable change in cells, for example, the number of lymphoblasts increased by $3.44 \%$, average lymphacites increased by $2.03 \%$, small lymphacites by $316.8 \%$. Apoptotic bodies $59.8 \%$, mitoses by $2.1 \%$, Thymus Gassal increased by $0.09 \%$. Macrophage 
index increased by $0.12 \%$. Stereometric characteristic of cortical substance of seven monthly rats 26 $.67 \%$. The medullar parts increased by $6.99 \%$., The intra perivascular space (runway) by $1.66 \%$. Interstitial septs increased by $7.98 \%$

\section{Figures 1-5}

In the conditions of the middle mountain Cholpon-Ata (1660 m above sea level), the cell indices decreased, for example, the number of lymphoblast indices is $2.33 \%$, the average lymphacites are $1.96 \%$, small lymphacites by $285.21 \%$. Apoptotic bodies by $60.6 \%$, mitoses by $2.13 \%$, Thymus Gassal grew by $0.05 \%$. Macrophage rates increased by $0.14 \%$. The stereometric characteristic of the cortical parts is $17.34 \%$. The medullar parts is $6.62 \%$. Intra perivascular space (runway) by $1.32 \%$. Interstitial septs are 5.68\% (Figures 1-5).

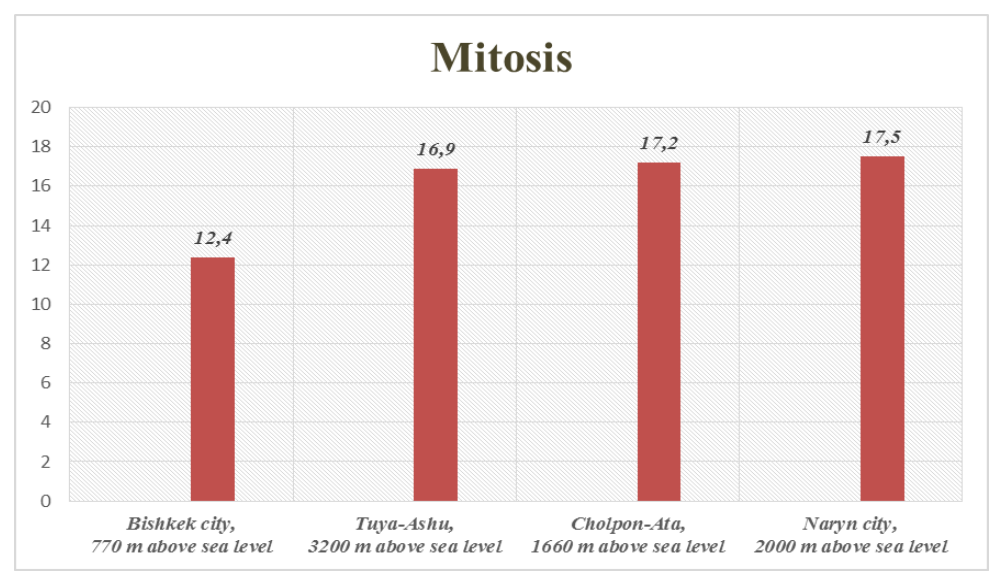

Figure 1 Mitoses. Indicators in different regions.

The performance of this study of seven month rats in the conditions of the highlands of Naryn (2000 $\mathrm{m}$ above sea level), the dynamics of cell populations in the unit of the conditional area of the cortical substance of the thymus slice in seven monthly rats slightly decreased the cell performance compared to the average Cholp-Ata (Figures 1-5).

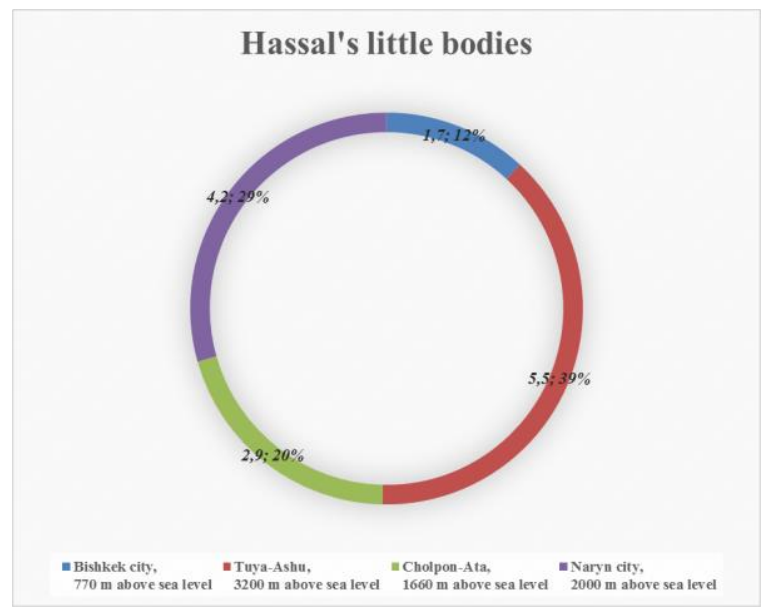

Figure 2. Gassal's body. Indicators in different regions. 


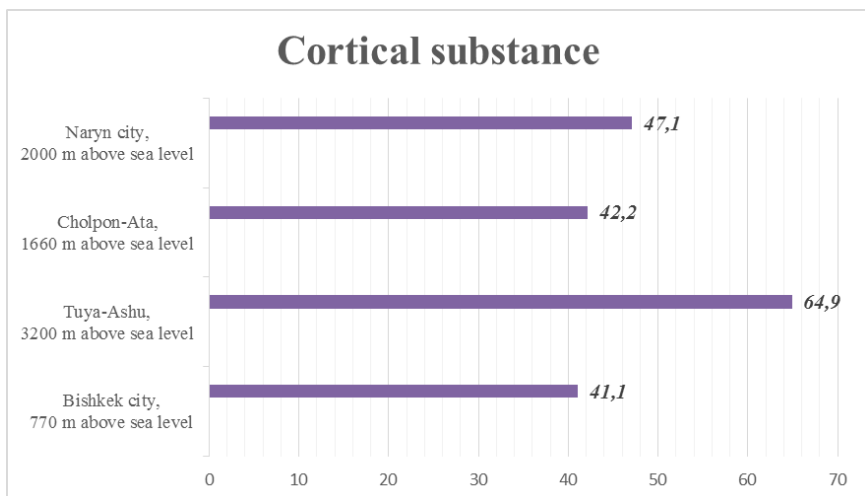

Figure 3. Cortical substance. Indicators in different regions.

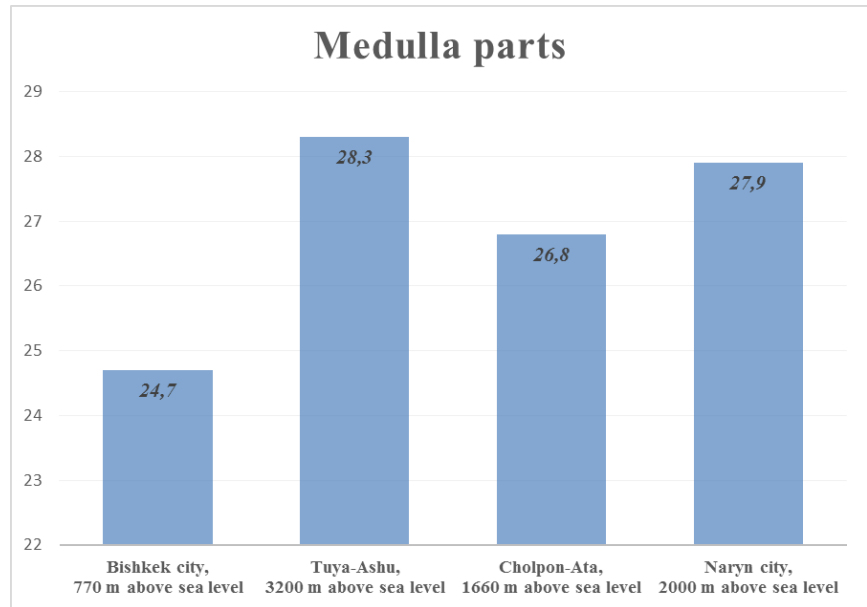

Figure 4. Medulla parts. Indicators in different regions.

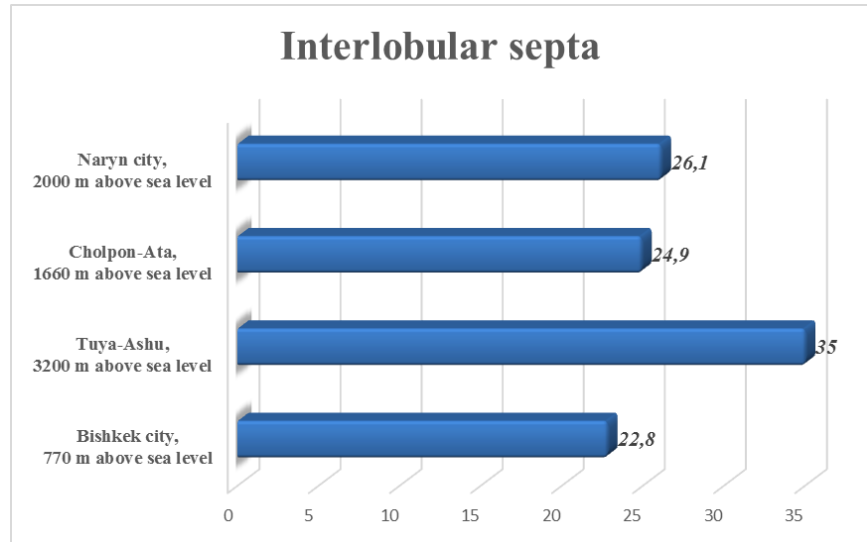

Figure 5. Interdigital septs. Indicators in different regions

Thus, the city of Bishkek in low-mountains conditions, i.e. $770 \mathrm{~m}$ above sea level, all indicators of the control group are within the normal range. In high-mountains conditions $(3200 \mathrm{~m}$ above sea level), reading of all cells increased. The data of Cholpon-Ata compared to Bishkek are slightly 
increased. In mountainous Naryn (2000 m above sea level) slightly decreased performance of the cells compared to medium Cholpon-Ata.

\section{REFERENCES}

1. Abaeva T.S. Morphological changes of thymus in rats in the highlands//Medicine. Kyrgyzstan No. 7, October 2013. - Bishkek, - C.29-30.

2. Abaeva of T.S. Zhanganayev of M.T. Abdykerimov of S.K. A.S. Malyanchinov. Morphological features of a timus at newborns крысД//"RE-HEALTH" an ilmy-amaly electron журналлар Sizlarni's takhririyat a 2020-yilning 20 August to kuna. No. 22 (6) 2020. Andijan, - C.143 - 148.

3. Aminova G. G. Morphological characteristic of lymphoid tissue in newborn children//Morphology. 2000. - T. 118, No. 6. - S. 53 - 56.

4. Berova M.O. Age-related features of the body's immunophysiological reaction to adaptation to hypoxia/dissertation for the candidate of biological sciences. 2004.- C.144. Nalchik.

5. Budaeva, E.K. Echographic characterization of changes in the thyroid gland in normal and pathological conditions in newborns\\Autoreferat. Moscow. 2007.

6. Dzhunusova, G.S. The central mechanisms of adaptation of the person in mountains [Text] / G.S. Dzhunusova. - Bishkek: KRSU publishing house, 2013. - The 280th page 12953. Dzhunusova, G.S. Mountain residents of Kyrgyzstan: Features of neurodynamic parameters of a brain [Text]//Ulyanovsk medicobiological magazine / G.S. Dzhunusova. - 2013. - No. 1. - Page 116 - 123.

7. Shanazarov, A.S. Bioclimatic zoning of mountain territories [Text $] / / \mathrm{V}$ prince: Mountains of Kyrgyzstan. Ed. Aydaraliev A.A./A.S. Shanazarov, T.B. Chernook, M.Yu. Glushkov. Bishkek: Technology. 2001. - S. 23 - 33.

8. Beall, C.M. Two pathways to functional adaptation: Tibetan and Andean high-level aborigines [Text ]//Sound. Natl. Acad. Sci. U.S.A./C.M. Beall. - 2007). - 104 (Suppl. 1), 8655-8660 doi: 10.1073/pnas.0701985104.

9. Heath D. High-altitude medicine and pathology [Text ]/D. Heath, D.R. Williams. - 1995. - 4th ed. - London, 2007. - 484p.

10. Hormonal Regulation of Immune Response in Northern Adaptation [Text ]//12th International Congress of Immunology and 4 Annual FOCIS Conference ./E.V. Tipisova, L.S. Shchegoleva, L.K. Dobrodeeva and others - Montreal, 2004.- P. 183.

11. Mimyra, Y. Mechanisms of adaptation to hypoxia in energy metabolism in rats [Text ]/J.Am.Col.Sury./Y. Mimyra, K. Furuya - 1995, Nov. - P. 437 - 443. 


\title{
INHERITED THROMBOPHILIA AND COVID-19
}

\author{
Nino Pirtskhelani ${ }^{1}$, Nino Kochiashvili ${ }^{2}$, Ketevan Kartvelishvili ${ }^{3}$, Levan Makhaldiani ${ }^{4}$ \\ ${ }^{1}$ Expert of Forensic Biology (DNA) Department, National Forensics Bureau. Professor of Tbilisi Open University; MD, \\ PhD., Georgia, Email: ninopirtskhelani@yahoo.com; Georgia. \\ ${ }^{2}$ Head of Biology (DNA) Department, National Forensics Bureau, MD, PhD, Email: nkochiashvili@yahoo.com; Georgia \\ ${ }^{3}$ Expert of Biology (DNA) Department, National Forensics Bureau, PhD Student, TSMU, Georgia. \\ Email: ketikartvelishvili@yahoo.com \\ ${ }^{4}$ Head of Hemophilia and Thrombosis Centre, K. Eristavi National Center of Experimental and Clinical Surgery, MD, \\ Georgia. Email: leo_makh@yahoo.com
}

Introduction: COVID-19, which is caused by severe acute respiratory syndrome coronarvirus 2 (SARS-CoV-2), has spread across the globe. Although most patients recover within 1 to 3 weeks, COVID-19 has already caused $>1500000$ deaths all over the world. SARS-CoV-2 enters cells by binding to the angiotensin-converting enzyme 2 receptor, which is expressed on respiratory epithelial cells and other cell types, including endothelial cells. Unchecked viral replication induces a florid host response characterized by dysregulation of inflammation and coagulation. Dysregulation of coagulation produces a coagulopathy associated with hypercoagulability as evidenced by venous and arterial thrombosis and multiorgan dysfunction. Up to $20 \%$ of affected patients require hospitalization, and the mortality rate in such patients is high.

The coagulopathy associated with COVID-19 is characterized by mild thrombocytopenia, slight prolongation of the prothrombin time, high levels of D-dimer, and elevated levels of fibrinogen, factor VIII, and von Willebrand factor. The levels of D-dimer, a breakdown product of cross-linked fibrin, correlate with disease severity and predict the risk of thrombosis, the need for ventilatory support, and mortality [1].

Novel coronavirus pneumonia (NCP) (COVID-19) is a disease caused by the enveloped viral pathogen severe acute respiratory syndrome coronavirus 2 (SARS-CoV-2). NCP, which is a major health problem worldwide, still has no definitive treatment or vaccine. Acute respiratory distress syndrome (ARDS) and sepsis are the main complications of the disease [2]. Additionally, disseminated intravascular coagulation (DIC) is one of the main underlying causes of death among patients [1]. A high number of thrombotic complications exist, and the incidence of thrombotic disease in individuals affected by NCP is reported to be $31 \%$ [3]. The brain and lungs were affected by the hypercoagulable state, and anticoagulant therapy should be started in these NCP patients [4].

Although the underlying pulmonary pathophysiology remains incompletely understood, severe COVID-19 infection is associated with a marked alveolar inflammatory cell infiltrate, together with a systemic cytokine storm response [5]. Several studies have also reported evidence of a COVID-19 associated coagulopathy $[6,7,8]$. Furthermore, multivariate regression analysis in Chinese COVID-19 cohorts reported that elevated plasma levels of fibrin degradation D-dimers constituted an independent biomarker for poor prognosis in COVID-19 [8]. Consistent with the hypothesis that coagulation activation may play a role in COVID-19 pathogenesis, post-mortem studies have highlighted marked pathological changes specifically involving the lung microvasculature, including disseminated micro-thrombi and significant hemorrhagic necrosis $[9,10]$. Moreover, emerging data suggest that severe COVID-19 is also associated with a significant increased risk for developing deep vein thrombosis and pulmonary embolism [11,12]. 
Inherited thrombophilia is a genetic disorder of blood coagulation resulting in a hypercoagulable state, which has been suggested as a possible cause of recurrent thromboembolism. Family and twin studies have established a heritable component to venous and arterial thrombosis. For the vast majority of patients, thrombosis is a complex, multifactorial disease caused by a combination of numerous, often unknown, environmental and genetic factors [13].

.The aim of this study was to analyze how important is to perform genetic testing for detection the intensity of connection between inherited thrombophilia (Factor V Leiden, Prothrombin G20210A and MTHFR C677T gene mutations) and the incidence of thrombotic disease in individuals affected by NCP.

Materials and methods: 1340 unrelated Georgians with thromboembolism and pregnancy complications were genotyped by PCR analyses for detection rate of inherited thrombophilia (Factor V Leiden (FVL), Prothrombin (PTH G20210A) and Methylenetetrahydrofolatereductase (MTHFR C677T) gene mutations). Studied gene mutation were detected by the molecular-genetics methods, which implied the following stages:

I. Extraction of genomic DNA: The genomic (nuclear) DNA was isolated from the peripheral blood leukocytes by a commercially available DNA extraction kit (Pronto Diagnostics).

For the detection of mutation in the extracted DNA, was used Pronto kits (Pronto Diagnostics, Israel) [14], which detects Single Nucleotide Substitution by a single nucleotide primer extension reaction, followed by Enzyme Linked Immuno-Sorbent Assay (ELISA).

II. Identification of mutation stages in genomic DNA

1. DNA amplification by Polymerase Chain Reaction (PCR), Gene Amp PCR System 9700 (Applied Biosystems) and Pronto BRCA Amplification Mix;

2. Detection of amplified DNA by gel-electrophoreses

3. Wild type and mutation-positive allele detection by a single nucleotide primer extension reaction using Gene Amp PCR System 9700 (Applied Biosystems) thermocycler;

4. Wild type and mutation-positive allele detection by Enzyme Linked Immuno-Sorbent Assay (ELISA);

5. Date detection by photometer-reader.

The PRONTO Product line is for in vitro diagnostic use and is accredited to the highest international quality standards of production including GLP/GMP, EN46001, ISO 9001 and ISO 13485 and is CE certified.

Results: As a result of our study it is possible to consider Leiden, Prothrombin and MTHFR mutations, especially its homozygous form and double heterozygous carriage as an independent high risk factors for development of thromboembolism. Distribution of studied mutations in Georgian general population is high and resembles upper data of Caucasians. This study in our population shows that inherited thrombophilia has significant impact on development of blood coagulation disorders in Georgian population.

Table. Distribution of mutation in Georgian population patients

\begin{tabular}{|l|l|l|l|l|l|l|}
\hline $\begin{array}{l}\text { Georgian } \\
\text { Population }\end{array}$ & \multicolumn{2}{|l|}{ FV Leiden } & \multicolumn{2}{l|}{ Pr G20210A } & \multicolumn{2}{l|}{ MTHFR C677T } \\
\hline Valid & Frequency & Percent & Frequency & Percent & Frequency & Percent \\
\hline Norma & 1245 & 92.9 & 1286 & 96.0 & 747 & 55.7 \\
\hline
\end{tabular}




\begin{tabular}{|l|l|l|l|l|l|l|}
\hline Hetero & 90 & 6.7 & 52 & 3.9 & 500 & 37.3 \\
\hline Homo & 5 & 0.4 & 2 & 0.1 & 93 & 7.0 \\
\hline Total & 1340 & 100.0 & 1340 & 100.0 & 1340 & 100.0 \\
\hline
\end{tabular}

Discussion and conclusion: The risk of thrombosis and arterial and venous thromboembolic complications seen in $30 \%$ of hospitalized subjects due to NCP has been reported in many studies, which can be explained by the prolonged inflammatory response, decreased physical activity during infection, and reduced oxygen levels in the circulation. Some reports raise the alarm regarding this complication, such as increased thromboembolism incidence despite prophylaxis [15], sevenfold increase in large vessel stroke in some patients who experienced either no or mild COVID-19 symptoms [16], cerebral infarct occurrence in NCP diagnosed patients with thrombocytopenia, coagulopathy, and increased anticardiolipin antibodies [17] which is very worrying and needs further investigation of the molecular basis of this phenomenon.

In the literature, lung thromboembolism as well as thrombus in different localizations has been reported in NCP cases [18,19] also detected fibrin thrombi in small vessels and capillaries and argued that it would be beneficial to use agents that also treat thrombotic and microangiopathic effects caused by the virus [20], but in other studies investigating the frequency of suspected common SNPs of $F I I, F V$ and $P A I-1$ genes were no statistically significant differences between the severe patient group and healthy population in SNPs and despite this fact that as there is an obvious relation between severe NCP and genetic thrombophilia susceptibility, there is a need for studies focused on other thrombophilia-related genetic factors and disease [2].

According to our previous studies, which are the first studies in our population, Leiden mutation, especially its homozygous form and double/triple heterozygous/homozygous carriage of the thrombophilia gene mutations is possible to consider as an independent risk factor of development of recurrent thrombosis in the Georgian population and prolong anticoagulation therapy in patients of similar genotype as much as possible to prevent recurrent thrombosis and related complications [21], we also think, that genetic predisposition to the thrombosis play important role in development of thrombotic complications in Georgian patient with NCP and it is reasonable to continue studies for detection of association between different thrombophilia-related genetic factors and coagulopathy associated with COVID-19.

\section{REFERENCES}

1. Noel C. Chan, Jeffrey I. Weitz. COVID-19 coagulopathy, thrombosis, and bleeding; Blood (2020) 136 (4): 381-383.https://doi.org/10.1182/blood.2020007335

2. Aslihan Kiraz, Seda Guzeldag, Esma Eren, Musa Goksu, Arslan Bayram. The Investigation of the Relationship Between the Inherited Thrombophilia and Novel Coronavirus Pneumonia. DOI:10.21203/rs.3.rs-81476/v1.

3. Rico-Mesa JS, Rosas D, Ahmadian-Tehrani A, White A, Anderson AS, Chilton R (2020) The role of anticoagulation in COVID-19-induced hypercoagulability. Current cardiology reports $22(7): 1-6$

4. Shawkat A, Merrell ET, Fadel GA, Amzuta I, Amin H, Shah AJ, Habeb H, Aiash H (2020) Multiple Thrombotic Events in a 67-Year-Old Man 2 Weeks After Testing Positive for SARS-CoV-2: A Case Report. The American journal of case reports 21:e925786. doi:10.12659/ajcr.925786 
5. Xiong Y, Liu Y, Cao L, et al. Transcriptomic characteristics of bronchoalveolar lavage fluid and peripheral blood mononuclear cells in COVID-19 patients. Emerg Microbes Infect.

6. Wang D, Hu B, Hu C, et al. Clinical Characteristics of 138 Hospitalized Patients With 2019 Novel Coronavirus-Infected Pneumonia in Wuhan, China. JAMA. 2020.

7. Tang N, Li D, Wang X, Sun Z. Abnormal coagulation parameters are associated with poor prognosis in patients with novel coronavirus pneumonia. J Thromb Haemost. 2020;18(4):844847.

8. Zhou F, Yu T, Du R, et al. Clinical course and risk factors for mortality of adult inpatients with COVID-19 in Wuhan, China: a retrospective cohort study. Lancet. 2020;395(10229):1054- 1062.

9. Luo $\mathrm{W}, \mathrm{Yu} \mathrm{H}$, Guo $\mathrm{Z}$ et al. Clinical pathology of critical patient with novel coronavirus pneumonia (COVID-19). Preprints 2020 (www.preprints.org).

10. Ding Y, Wang $\mathrm{H}$, Shen $\mathrm{H}$, et al. The clinical pathology of severe acute respiratory syndrome (SARS): a report from China. J Pathol. 2003;200(3):282-289.

11. Klok FA, Kruip M, van der Meer NJM, et al. Incidence of thrombotic complications in critically ill ICU patients with COVID-19. Thromb Res. 2020. 12. Cui S, Chen S, Li X, Liu S, Wang F. Prevalence of venous thromboembolism in patients with severe novel coronavirus pneumonia. J Thromb Haemost. 2020.

12. Srikanth Nagalla and Paul F. Bray. Personalized medicine in thrombosis: back to the future. 2018. BLOOD, 2 JUNE 2016 x VOLUME 127, NUMBER 22

13. Carmi N, Cohen D, Zvang E, Naparstek E, Deutsch V. Pronto ThromboRisk-a novel primerextension ELISA based assay for the detection of mutations associated with increased risk for thrombophilia. JClin Lab Anal. 2004;18(5):259-64.

14. Middeldorp S, Coppens M, van Haaps TF, Foppen M, Vlaar AP, Müller MC, Bouman CC, Beenen LF, Kootte RS, Heijmans J (2020) Incidence of venous thromboembolism in hospitalized patients with COVID-19. Journal of Thrombosis and Haemostasis

15. Oxley TJ, Mocco J, Majidi S, Kellner CP, Shoirah H, Singh IP, De Leacy RA, Shigematsu T, Ladner TR, Yaeger KA (2020) Large-vessel stroke as a presenting feature of Covid-19 in the young. New England Journal of Medicine 382 (20):e60

16. Zhang Y, Xiao M, Zhang S, Xia P, Cao W, Jiang W, Chen H, Ding X, Zhao H, Zhang H (2020) Coagulopathy and antiphospholipid antibodies in patients with Covid-19. New England Journal of Medicine 382 (17):e38

17. Carsana L, Sonzogni A, Nasr A, Rossi RS, Pellegrinelli A, Zerbi P, Rech R, Colombo R, Antinori S, Corbellino M (2020) Pulmonary post-mortem findings in a series of COVID-19 cases from northern Italy: a two-centre descriptive study. The Lancet Infectious Diseases

18. Doo FX, Kassim G, Lefton DR, Patterson S, Pham H, Belani P (2020) Rare presentations of COVID-19: PRES-like leukoencephalopathy and carotid thrombosis. Clinical Imaging

19. Fox SE, Akmatbekov A, Harbert JL, Li G, Brown JQ, Vander Heide RS (2020) Pulmonary and cardiac pathology in Covid-19: the first autopsy series from New Orleans. MedRxiv

20. Pirtskhelani N, Kochiashvili N, Makhaldiani L, Pargalava N, Gaprindashvili E, Kartvelishvili K.. Impact of inherited thrombophilia on the risk of recurrent venous thromboembolism onset in Georgian population. Georgian Med News. 2014 Feb;(227):93-7. 


\section{IMPACT OF ANGIOTENSIN-1 CONVERTING ENZYME GENE INSERTION/DELETION (I/D) POLYMORPHISM ON DIABETES MELLITUS SUSCEPTIBILITY AMONG AZERBAIJAN POPULATION}

\section{Lala Akhundova, Gulmira Alibayova, Nurmammad Mustafayev, Samira Rustamova, Irada Huseynova}

Institute of Molecular Biology and Biotechnologies, Azerbaijan National Academy of Sciences, Azerbaijan;

E-mail: imbb@science.az

The association between the angiotensin-converting enzyme (ACE) insertion/deletion (I/D) gene polymorphism and the risk of diabetes mellitus developing in the Azerbaijan population is not studied yet. Therefore, the aim of the present study was to investigate the association of ACE I/D gene polymorphism and the risk of developing diabetes in Azerbaijan population. A total of 200 individual consisting of 100 control subjects and 100 patients with diabetes mellitus (28 patients I type DM (11 male and 17 female); 72 patients II type DM (21 male and 51 female)) were recruited. DNA was extracted from the blood samples. Genotyping of ACE I/D gene polymorphism done by PCR and mistyping of the II and DD genotypes was conducted with an insertion/deletion-specific primer. The genotyping frequency for the II, ID and DD polymorphism of the ACE gene ID=63, $\mathrm{DD}=36, \mathrm{II}=1$ in case subjects. The genotyping frequency for the II, ID and DD polymorphism of the ACE gene in control group: $\mathrm{ID}=49, \mathrm{DD}=26, \mathrm{II}=25$. The frequency for the $\mathrm{D}$ allele is 0.67 and the frequency of I allele is 0.325 in case group. The frequency for the $\mathrm{D}$ allele is 0.505 and the frequency of I allele is 0.495 in control group. The dominant and recessive models revealed alleles on separate groups and at the population level: $\mathrm{DD}: \mathrm{DR}=13.6$; ID:IR=15; ID:DD=0.35; DD:ID= 2.97; DR: $\mathrm{IR}=3.26$; IR:DR=0.3. Based on the results, $\mathrm{D}$ allele showed significant association with risk of disease. This finding revealed the association of I/D polymorphism with risk of type 2 diabetes. However, further studies with larger sample size are necessary to confirm the association of the I/D polymorphism of the ACE gene and diabetes mellitus in Azerbaijan population.

Introduction: Diabetes mellitus (DM) is a group of metabolic disorders characterized by a high blood sugar level over a prolonged period. Based on the report of the World Health Organization Azerbaijan has one of the highest rates of diabetes mortality in the European Region. However, in terms of diabetes prevalence, Azerbaijan is in a middle-ranking position. It's known that the main factors that may cause diabetes are sedentary lifestyle, diet, stress etc. However, genetic predisposition may play a key role in the development and etiology of diabetes (Flores-Martínez et al., 2004; Elbein, 1997). Therefore, several studies evaluated the role of genetic variants in ReninAngiotensin-Aldosterone System (RAAS) in association with risk of diabetes (Ichikawa et al., 2014; Al-Rubeaan et al., 2013; Shaikh et al., 2014). Most of them have focused on the main component of the RAAS, the Angiotensin Converting Enzyme $(A C E)$ that is converting angiotensin I to the vasoactive peptide angiotensin II and play an important role in the mediation of cellular function in different tissues.

The RAAS that include renin inhibitors, ACE inhibitors, angiotensin II type 1 receptor antagonists, and mineralocorticoid receptor antagonists, is known as a regulator of hypertension and fluid as well as electrolyte homeostasis. ACE is a key enzyme in the RAAS.

The ACE gene is located in chromosome 17 (17q23 region) and contains a polymorphism based on 


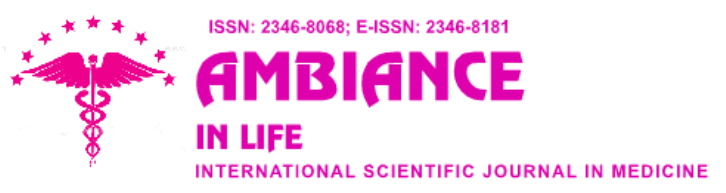

the presence (insertion) or absence (deletion) of a 287 base-pair (bp) fragment on $16^{\text {th }}$ intron of ACE gene (Turgut et al., 2004). ACE I/D polymorphism influence on the level of ACE in plasma and associated with a higher risk for diabetes. Three ACE genotypes - II, ID, and DD, have a different correlation with the percentage of hypertension, myocardial hypertrophy, diabetes mellitus, psychological disorders and other diseases. The D allele is associated with an increased risk of developing diabetes (Purnamasari et al., 2012; Pan et al., 2016; MirFeizi et al., 2018; Pirozzi et al., 2018; Shen et al., 2019).

\section{Materials and methods:}

Population Studied: The fresh blood samples were collected on a voluntary basis from 200 individuals in different ages and with different professional activities. The studied population sample include following groups: 100 controls and 100 patients with diabetes mellitus (28 patients I type DM (11 male and 17 female); 72 patients II type DM (21 male and 51 female)).

DNA isolation procedures: DNA from $200 \mu$ blood samples was isolated using "Diatom ${ }^{\mathrm{TM}}$ DNA Prep 200" kit (Izogen, Russian Federation) on manufacturer protocols. The concentrations and purity of the DNA samples were determined spectrophotometrically in Epoch ${ }^{\mathrm{TM}}$ Microplate Spectrophotometer (BioTek, Aglient, USA) using Gene5 software. DNA samples were diluted individually before PCR.

Detection of I/D Polymorphism of ACE gene: ACE polymorphism on $16^{\text {th }}$ intron was determined by polymerase chain reaction (PCR) using two pairs of specific primers: ACE-F (5'CTGGAGACCACTCCCATCCTTTCT-3') and ACE-R (5'-GATGTGGCCATCACATTCGTCA GAT-3') (Rigat et al., 1992).

The obtained DNA fragments were electrophoresed in a 1.5\% agarose gel and visualized by ethidium bromide staining. The sizes of fragments were estimated by comparison with previously known molecular weight markers M100. The polymorphism detected by PCR was evident as a 490-bp fragment in the presence of the insertion (I allele) and as a 190-bp fragment in the absence of the insertion (D allele). Each sample found to have the D/D genotype was subjected to a second PCR amplification with insertion-specific primers (5a: 5'-TGGGACCACAGCGCCCGCCACTAC-3' and 5c: 5'-TCGCCAGCCCTCCCATGCCCATAA-3') in order to avoid D/D mistyping (Shanmugam et al., 1993).

Results: Among 100 patients, 28 patients had type I DM (11 male and 17 female), and 72 patients had type II DM (21 male and 51 female). There mean age was $50 \pm 10$ years. The control group

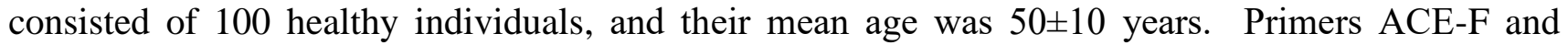
ACE-R revealed an insertion-specific 490 bp fragment in 26 samples, deletion-specific 190 bp fragments in 62 samples, and insertion-deletion fragments of both types in 112 samples in the total studied population (Fig. 1). 


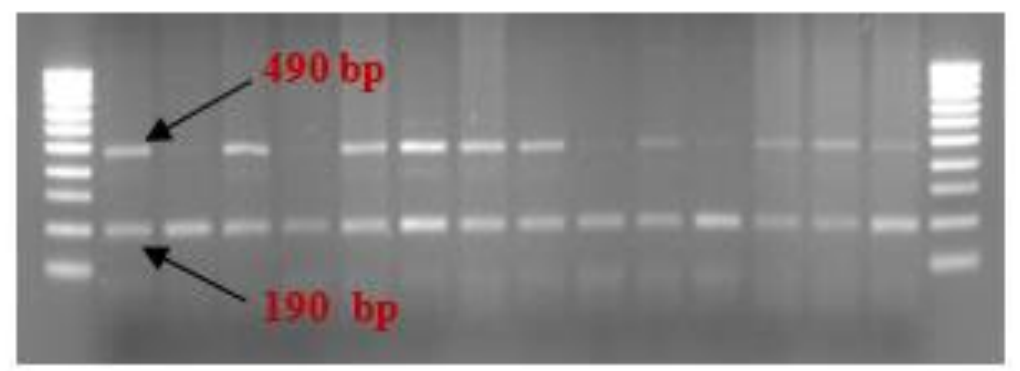

Figure 1 The amplification results with the ACE-F and ACE-R primers

Table 1 Genotype distribution of I/D polymorphism of ACE gene in diabetic patients and controls.

\begin{tabular}{|l|l|l|l|l|}
\hline ACE genotype & Diabetic $(\mathrm{n}=100)$ & Control $(\mathrm{n}=100)$ & OD $(95 \% \mathrm{CI})$ & $P$ value \\
\hline DD n $(\%)$ & $36(36)$ & $26(26)$ & $34.6(4.4053-271.9954)$ & 0.0008 \\
\hline ID n (\%) & $63(63)$ & $49(49)$ & $32.1(4.2072-245.5676)$ & 0.0008 \\
\hline II n $(\%)$ & $1(1)$ & $25(25)$ & $0.0289(0.0037-0.2270)$ & 0.0008 \\
\hline
\end{tabular}

Table 2 Allele frequency of I/D polymorphism of ACE gene in diabetic patients and controls

\begin{tabular}{|l|l|l|l|l|}
\hline ACE allele & Diabetic $(\mathrm{n}=100)$ & Control $(\mathrm{n}=100)$ & OD $(95 \% \mathrm{CI})$ & $P$ value \\
\hline $\mathrm{D} \mathrm{n}(\%)$ & $135(67.5)$ & $101(50.5)$ & $2.0358(1.3572-3.0537)$ & 0.006 \\
\hline $\mathrm{In}(\%)$ & $65(32.5)$ & $99(49.5)$ & $0.4912(0.3275-0.7368)$ & 0.006 \\
\hline
\end{tabular}

$* \mathrm{p}<0.05$ is significant

Table 3 Analysis of dominant and recessive models of ACE I/D polymorphism

\begin{tabular}{|l|l|l|l|}
\hline Model & Diabetic patients & Control & Study population \\
\hline $\begin{array}{l}\text { Dominant model (D allele) } \\
\text { (DD+ID)/II }\end{array}$ & 99 & 3 & 6.69 \\
\hline $\begin{array}{l}\text { Recessive mode (D allele) } \\
\text { DD/(ID+II) }\end{array}$ & 0.57 & 0.35 & 0.49 \\
\hline $\begin{array}{l}\text { Dominant model (I allele) } \\
\text { (II+ID)/DD }\end{array}$ & 1.78 & 2.84 & 2.25 \\
\hline $\begin{array}{l}\text { Recessive mode (I allele) } \\
\text { II/(ID+DD) }\end{array}$ & 0.01 & 0.33 & 0.15 \\
\hline
\end{tabular}

Genotype distribution in diabetic patients as well as in controls presented in Table 1. The frequency of DD genotype was higher in the diabetic group (36\%) compared with control (26\%). Additionally, the frequency of II genotype was higher in the control group (25\%). The DD genotype vs II genotype in the diabetic group associated with increased risk of diabetes $(\mathrm{OR}=34.6$; 95\% $\mathrm{CI}=4.4053-271.9954$; $\mathrm{P}=0.0008$ ).

Allele frequency in diabetic patients and control represented in Table 2. The D allele of the ACE gene is more frequent among diabetic patients than in control while I allele is more frequent in the control group compared to the diabetic group. The D allele vs I allele is associated with increased risk of diabetes $(\mathrm{OR}=2.0358 ; 95 \% \mathrm{CI}=1.3572-3.0537 ; \mathrm{P}=0.006)$.

The values of the ratios $D_{D}: D_{R}=13.6 ; I_{D}: I_{R}=15 ; I_{D}: D_{D}=0.35 ; D_{D}: I_{D}=2.97 ; D_{R}: I_{R}=3.26 ; I_{R}: D_{R}=0.3$ 
indicate that the allele D and DD genotype is associated with risk of developing diabetes (Table 3).

Discussion and conclusion: The renin-angiotensin-aldosterone system (RAAS) is known as an important system in regulating electrolyte balance as well as blood pressure. This system plays an essential role in genetic predisposition to hypertension and diabetes type 2. High plasma and serum ACE level genetically determined by I/D polymorphism of the ACE gene. The II genotype is referred to as protective genotype since it's associated with low activity of the ACE gene. In comparison, DD genotype is associated with higher ACE activity and expression and therefore, might predispose individuals to type 2 DM (Stephens et al., 2005). In our study, the DD genotype and the D allele strongly associated with diabetes. This finding confirm previous studies that were done in a way to show the genetic predisposition of I/D polymorphism to DM (Zarouk et al., 2012; Al-Saikhan et al., 2017; Dhumad et al., 2020). The study conducted in Egyptian patients showed increase frequency of D allele as well as DD genotype in diabetic patients in comparison to the control group (Zarouk et al., 2012). Recent study of M.M.Dhumad showed that the D allele of the ACE I/D gene polymorphism could be a risk factor for T2DM and cardiac autonomic neuropathy formation among Iraqi patients (Dhumad et al., 2020). However, several studies contradict these statements. For instance, study conducted on the Turkish population found no significant association between allele D of the ACE gene and risk for type 2 DM (Gunes et al., 2004). Meanwhile, Grammer and colleagues investigated that all three genotypes of I/D polymorphism occurred in the same frequency in patients with type 2 DM compared to the control group among the Caucasian population (Grammer et al., 2006).

The molecular mechanism by which D/D genotype could be a potential candidate as a risk factor for $\mathrm{DM}$ is that the high level of ACE decreases glucose utilization in skeletal muscles during exercise. In contrast, low activity of ACE increases insulin sensitivity, glucose transporter GLUT-4 synthase activity and hexokinase activity (Dietze et al., 2008). Those, high activity of ACE that is regulating by D/D genotype seems to increase the risk of DM.

Even though our sample size was relatively small, the result of this study confirmed that the DD genotype, as well as D allele of I/D polymorphism of ACE gene, has a positive association with DM. However, further studies with a large sample size are necessary to confirm these findings. Moreover, the exact molecular mechanism, by which this polymorphism could alter glucose metabolism, should be studied. Additionally, other polymorphisms of the ACE gene should be studied, in a way of their possible impact on glucose homeostasis.

\section{REFERENCES}

1. Al-Rubeaan K., Siddiqui K., Saeb A. T. M., Nazir N., Al-Naqeb D., Al-Qasim S. (2013) CE I/D and MTHFR C677T polymorphisms are significantly associated with type 2 diabetes in Arab ethnicity: a meta-analysis. Gene, 520(2): 166-177; doi: 10.1016/j.gene.2013.02.017.

2. Dietze G.J., Henriksen E.J. (2008) Angiotensin-converting enzyme in skeletal muscle: sentinel of blood pressure control and glucose homeostasis. J. Renin Angiotensin Aldosterone Syst., 9(2): 75-88; doi: 10.3317/jraas.2008.011.

3. Elbein S.C. (1997) The genetics of human noninsulin-dependent (type 2) diabetes mellitus. Journal of Nutrition, 127(9): 1891S-1896S; doi: 10.1093/jn/127.9.1891S.

4. Al-Saikhan F.I., Abd-Elaziz M.A., Ashour R.H. (2017) Association between risk of type 2 diabetes mellitus and angiotensin-converting enzyme insertion/deletion gene polymorphisms in a Saudi Arabian population. Biomedical Reports, 7: 56-60; doi: 10.3892/br.2017.920. 
5. Flores-Martínez S.E., Islas-Andrade S., MacHorro-Lazo M.V. et al. (2004) DNA polymorphism analysis of candidate genes for type 2 diabetes mellitus in a Mexican ethnic group. Annales de Genetique, 47(4): 339-348; doi: 10.1016/j.anngen.2004.05.004

6. Gunes H.V., Ata N., Degirmenci I., Basaran A., Timuralp B., Dikmen M., Ustuner C., Kudaiberdieva G. (2004) Frequency of angiotensin-converting enzyme gene polymorphism in Turkish hypertensive patients. Int. J. Clin. Pract., 58(9): 838-843; doi: 10.1111/j.17421241.2004.00206.x

7. Grammer T.B., Renner W., Von Karger S., Boehm B.O., Winkelmann B.R., Maerz W.T. (2006) The angiotensin-1 converting enzyme I/D polymorphism is not associated with type 2 diabetesin individuals undergoing coronary angiography. (The Ludwigshafen Risk and Cardiovascular Health Study). Mol. Genet. Metab., 88: 378-383; doi: 10.1016/j.ymgme.2006.01.008.

8. Ichikawa M., Konoshita T., Nakaya T. et al. (2014) Genetic variant of the renin-angiotensin system and prevalence of type 2 diabetes mellitus: a modest but significant effect of aldosterone synthase. Acta Diabetologica, 51(4): 595-599; doi: 10.1007/s00592-014-0561-7.

9. Mirfeizi M., Hasanzad M., Sattari M., Afshari M., Abbasi D., Ajoodani Z., Sheykheslam A.B. (2018) Association of eNOS and ACE gene polymorphisms as a genetic risk factor in gestational diabetes in Iranian women. J. Diabetes Metab. Disord., 17(2): 123-127; doi: 10.1007/s40200-018-0348-4.

10. Dhumad M.M., Hamdan F.B., Al-Mayah Q.S. (2020) Angiotensin-converting enzyme insertion/ deletion (I/D) gene polymorphism in Iraqi type 2 diabetic patients: association with the risk of cardiac autonomic neuropathy. Egyptian Journal of Medical Human Genetic. 21(20): 2-7; doi:10.1186/s43042-020-00062-8.

11. Pan Y.H., Wang M., Huang Y.M., Wang Y.H., Chen Y.L., Geng L.J., Zhang X.X., Zhao H.L. (2016) ACE gene I/D polymorphism and obesity in 1,574 patients with type 2 diabetes mellitus. Dis. Markers, 2016: Article ID 7420540, 6 p.; doi: 10.1155/2016/7420540.

12. Pirozzi F.F., Belini J.E., Okumura J.V., Salvarani M., Bonini-Domingos C.R., Ruiz M.A. (2018) The relationship between of ACE I/D and the MTHFR C677T polymorphisms in the pathophysiology of type 2 diabetes mellitus in a population of Brazilian obese patients. Arch. Endocrinol. Metab., 62(1): 21-26; doi: 10.20945/2359-3997000000005.

13. Purnamasari D., Widjojo B.D., Antono D., Syampurnawati M. (2012) ACE gene polymorphism and atherosclerotic lesion of carotid artery among offsprings of type 2 diabetes mellitus. Acta Med. Indones., 44(2): 128-34; PMID: 22745143.

14. Shaikh R., Shahid S. M., Mansoor Q., Ismail M., Azhar A. (2014) Genetic variants of ACE (insertion/deletion) and AGT (M268T) genes in patients with diabetes and nephropathy. Journal of the Renin-Angiotensin-Aldosterone System, 15(2): 124-130; doi: $10.1177 / 1470320313512390$.

15. Shen W., Jiang X.X., Li Y.W., He Q. (2019) I/D polymorphism of ACE and risk of diabetesrelated end-stage renal disease: a systematic review and meta-analysis. Eur. Rev. Med. Pharmacol. Sci., 23(4): 1652-1660; doi:10.26355/eurrev_201902_17126.

16. Stephens J.W., Dhamrait S.S., Cooper J.A., Acharya J., Miller G.J., Hurel S.J. et al. (2005) The D allele of the ACE I/D common gene variant is associated with type 2 diabetes mellitus in Caucasian subjects. Mol. Genet. Metab., 84: 83-89; doi.org/10.1016/j.ymgme.2004.09.002

17. Turgut G., Turgut S., Genc O., Atalay A., Atalay E.O. (2004) The angiotensin converting enzyme I/D polymorphism in Turkish athletes and sedentary controls. Acta Medica-Hradec 
Kralove, 47(2): 133-136; doi: 10.14712/18059694.2018.79.

18. Zarouk W.A., Hussein I.R., Esmaeil N.N., Raslan H.M., Reheim H.A.A., Moguib O., Emara N.A., Aly A.A., Hamed M. (2012)Association of angiotensin converting enzyme gene (I/D) polymorphism with hypertension and type 2 diabetes. Bratisl. Lek. Listy., 113(1): 14-18; doi: 10.4149/BLL_2012_003. 


\title{
OBESITY IN CHILDREN AS A FACTOR OF MYOCARDIAL REMODELING
}

\section{Zhanar Nurgaliyeva ${ }^{1,2}$, Shahniza Abdraimova ${ }^{3}$, Aliya Mahsutkhanova ${ }^{3}$, Nozima Holmirzaeva ${ }^{3}$, Kamola Khanseitova ${ }^{3}$, Saltanat Dzhantasova ${ }^{3}$}

\begin{abstract}
${ }^{1}$ Professor of the Department of Children's Diseases with a course in Neonatology, S. D. Asfendiyarov Kazakh National Medical University, Almaty, Kazakhstan, nurgaliyeva.z@kaznmu.kz

${ }^{2}$ Pediatrician of the Department of General Pediatrics, JSC "Scientific Center of Pediatrics and Pediatric Surgery", Kazakhstan, Email: nurgaliyeva.z@kaznmu.kz

${ }^{3}$ Resident in the specialty "Pediatrics" of the Department of Children's Diseases with the course of Neonatology, NPJSC «Asfendiyarov Kazakh National medical university», Kazakhstan

${ }^{3}$ Resident in the specialty "Pediatrics" of the Department of Children's Diseases with the course of Neonatology, NPJSC «Asfendiyarov Kazakh National medical university», Kazakhstan

${ }^{3}$ Resident in the specialty "Pediatrics" of the Department of Children's Diseases with the course of Neonatology, NPJSC «Asfendiyarov Kazakh National medical university», Kazakhstan

${ }^{3}$ Resident in the specialty "Pediatrics" of the Department of Children's Diseases with the course of Neonatology, NPJSC «Asfendiyarov Kazakh National medical university», Kazakhstan

${ }^{3}$ Resident in the specialty "Pediatrics" of the Department of Children's Diseases with the course of Neonatology, NPJSC «Asfendiyarov Kazakh National medical university», Kazakhstan
\end{abstract}

\section{ABSTRACT}

The epidemic of childhood obesity with the subsequent development of metabolic syndrome (MS), cardiovascular pathology and endocrine disorders causes the need for early diagnosis and timely treatment of children of this group, which allows us to consider this pathology the most urgent problem of modern medicine.

$28(28.6 \%)$ of the examined patients showed an increase in the content of IRI in the blood serum, 5 (5.1\%) had fasting glycemia, $6(6.1 \%)$ had impaired glucose tolerance, the excess of the HOMA index was observed in $56(57.1 \%)$, an increase in CS in $6(6.1 \%)$, TG in $18(18.4 \%)$. The combination of these changes includes children under the age of 10 years in the risk group for MS in $84.6 \%$, and in children 10 years and older; it is possible to diagnose MS in $56.9 \%$ of cases (IDF, 2007). Activation of neuro-humoral mechanisms and violation of metabolic processes contributed to the development of arterial hypertension in 24 (24.5\%) children, concentric LV remodeling in 18 (18.4\%), concentric LV hypertrophy in 8 (8.2\%) and eccentric LV hypertrophy in 7 (7.1\%) children according to the results of ECHO-KG.

Keywords: children, obesity, cardiovascular pathology, remodeling

\section{Introduction:}

Revelance:The epidemic of childhood obesity with the subsequent development of metabolic syndrome (MS), cardiovascular pathology and endocrine disorders causes the need for early diagnosis and timely treatment of children of this group, which allows us to consider this pathology the most urgent problem of modern medicine.

Patients and methods: 98 children and adolescents with abdominal obesity were examined (IDF, 2007). Blood pressure was measured, laboratory parameters of carbohydrate metabolism (fasting glucose level and after exercise after 2 hours, the level of immunoreactive insulin (IRI), calculation 
of the HOMA index) and lipid metabolism (cholesterol (CS), triglycerides (TG)) were studied, ECHO-KG was performed. Types of left ventricular (LV) remodeling were evaluated according to the classification of A. Ganau et al. in the modification of Devereux R.B. (1986).

Results of the study: 28 (28.6\%) of the examined patients showed an increase in the content of IRI in the blood serum, $5(5.1 \%)$ had fasting glycemia, $6(6.1 \%)$ had impaired glucose tolerance, the excess of the HOMA index was observed in $56(57.1 \%)$, an increase in CS in $6(6.1 \%)$, TG in 18 (18.4\%). The combination of these changes includes children under the age of 10 years in the risk group for MS in $84.6 \%$, and in children 10 years and older; it is possible to diagnose MS in $56.9 \%$ of cases (IDF, 2007). Activation of neuro-humoral mechanisms and violation of metabolic processes contributed to the development of arterial hypertension in $24(24.5 \%)$ children, concentric LV remodeling in $18(18.4 \%)$, concentric LV hypertrophy in 8 (8.2\%) and eccentric LV hypertrophy in 7 (7.1\%) children according to the results of ECHO-KG.

Conclusions: Thus, obesity in children and adolescents is accompanied by pronounced changes in carbohydrate and lipid metabolism and LV myocardial remodeling mainly in the concentric type, which indicates a high risk of cardiovascular diseases (CVD) and requires early correction of metabolic disorders, development of preventive measures.

\section{REFERENCES}

1. Logacheva I.V., Ryazanova T.A., Makarova V.R., Avzalova F.R., Maksimov N.I. Heart remodeling in overweight and obesity with cardiac comorbidities. Russian Journal of Cardiology. 2017;(4):40-46

2. Sharipova G.K., Saidova M.A., Zhernakova Yu.V., Chazova I.E. The influence of metabolic syndrome on heart abnormalities in patients with arterial hypertension. Almanac of Clinical Medicine. 2015;1(1):102-110

3. Nurgaliyeva Zh.Zh., Khabizhanov B.Kh., Ilmuratova S.Kh. p

4. olymorphism of genes operating in the metabolism of adipocytokines in obese children. Pediatrics and Pediatric Surgery. 2015;3(81):65-66 


\section{THYROID STATUS IN CHILDREN WITH TYPE 1 DIABETES MELLITUS}

${ }^{1,2}$ Zhanar Nurgaliyeva, ${ }^{3}$ Araily Manasbaeva, ${ }^{4}$ Sakhipzhamal Sabirova, ${ }^{4}$ Saiyara Nadyrova,

${ }^{4}$ Alfira Maratkyzy Muratkhan, ${ }^{4}$ Zakhrokhon Ergashbaeva, ${ }^{4}$ Alfiya Zhanzak

${ }^{1}$ Professor of the Department of Children's Diseases with a course in Neonatology,

S. D. Asfendiyarov Kazakh National Medical University, Kazakhstan, nurgaliyeva.z@kaznmu.kz

${ }^{2}$ Pediatrician of the Department of General Pediatrics, JSC "Scientific Center of Pediatrics and Pediatric Surgery", Kazakhstan, Email:nurgaliyeva.z@kaznmu.kz

${ }^{3}$ Master's student of the 2nd year of study of the Department of Children's Diseases with the course of Neonatology, Kazakhstan, Email: amanasbaeva@inbox.ru

${ }^{4}$ Intern 764 groups of the Department of Children's Diseases with the course of Neonatology, S.D. Asfendiyarov Kazakh National Medical University, Kazakhstan.

${ }^{4}$ Intern 764 groups of the Department of Children's Diseases with the course of Neonatology, S.D. Asfendiyarov Kazakh National Medical University, Kazakhstan.

${ }^{4}$ Intern 764 groups of the Department of Children's Diseases with the course of Neonatology, S.D. Asfendiyarov Kazakh National Medical University, Kazakhstan.

${ }^{4}$ Intern 764 groups of the Department of Children's Diseases with the course of Neonatology, S.D. Asfendiyarov Kazakh National Medical University, Kazakhstan

${ }^{4}$ Intern 764 groups of the Department of Children's Diseases with the course of Neonatology, S.D. Asfendiyarov Kazakh National Medical University, Kazakhstan.

\section{ABSTRACT}

The mutually aggravating effect of comorbid diseases of diabetes mellitus (DM) and autoimmune thyroiditis (AIT) is of scientific interest to researchers. Timely assessment of the thyroid status in children with DM and correction of thyroid pathology (TP) will improve metabolic control in these patients.

Among 972 children with DM, 478 (49.2\%) were assessed for thyroid status. It is noted that every year the determination of thyroid hormone levels in children increased from $7.6 \%$ (in 2014) to $92.1 \%$ (in 2019). Among 478 examined children, 319 (66.7\%) had significantly revealed thyroid dysfunction. In the structure of thyroid pathologies, the frequency of hypothyroidism was $12.5 \%$ (in $11.3 \%$ - subclinical form), hyperthyroidism - 4\%. functional changes in the concentration of thyroid hormones as Euthyroid sick syndrome were observed in 23.8\%. The most common type of dysfunction was an isolated increase in free T3 (isolated T3 toxicosis) - in $43.3 \%$ of cases. In 2 cases out of $18(0.6 \%)$, a complete picture of AIT was presented, and in the remaining $16(5.1 \%)$, signs of AIT were observed only on ultrasound of the thyroid gland, and were not confirmed by the concentrations of anti-TPO Ab, anti-TG Ab. In $47(14.7 \%)$ children, laboratory data on thyroid hormone levels showed elevated values of TSH, free T3, free T4.

Key words: children, diabetes mellitus, thyroid status, autoimmune thyroiditis

\section{Introduction:}




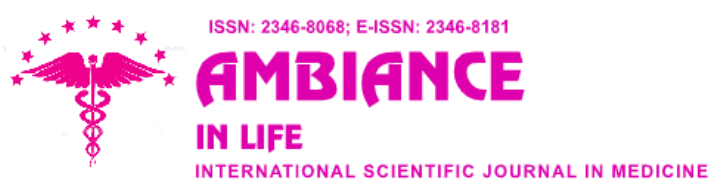

Revelance: The mutually aggravating effect of comorbid diseases of diabetes mellitus (DM) and autoimmune thyroiditis (AIT) is of scientific interest to researchers. Timely assessment of the thyroid status in children with DM and correction of thyroid pathology (TP) will improve metabolic control in these patients.[1,2].

Results: Material and methods: 972 case histories of patients with type 1 diabetes who were treated in the children's city clinical hospital (CCCH) No. 2 in Almaty (Kazakhstan) in the period from 2014 to 2019 were retrospectively analyzed for the functional state of the thyroid gland.

Results: among 972 children with DM, 478 (49.2\%) were assessed for thyroid status. It is noted that every year the determination of thyroid hormone levels in children increased from $7.6 \%$ (in 2014) to 92.1\% (in 2019). Among 478 examined children, 319 (66.7\%) had significantly revealed thyroid dysfunction. In the structure of thyroid pathologies, the frequency of hypothyroidism was $12.5 \%$ (in $11.3 \%$ - subclinical form), hyperthyroidism - $4 \%$. functional changes in the concentration of thyroid hormones as Euthyroid sick syndrome were observed in $23.8 \%$. The most common type of dysfunction was an isolated increase in free T3 (isolated T3 toxicosis) - in $43.3 \%$ of cases. In 2 cases out of $18(0.6 \%)$, a complete picture of AIT was presented, and in the remaining $16(5.1 \%)$, signs of AIT were observed only on ultrasound of the thyroid gland, and were not confirmed by the concentrations of anti-TPO Ab, anti-TG Ab. In 47 (14.7\%) children, laboratory data on thyroid hormone levels showed elevated values of TSH, free T3, free T4.

Conclusions: In more than half of cases, children with type 1 diabetes have thyroid dysfunction, among which T3-toxicosis syndrome is registered in $43.3 \%$ of cases, hypothyroidism in $12.5 \%$, and hyperthyroidism in $4 \%$. Undoubtedly, the correction of thyroid pathologies will contribute to a relatively favorable course of diabetes and the achievement of target indicators.

\section{REFERENCES}

1. Chase HP, Garg SK, Cockerham RS, Wilcox WD, Walravens PA. Thyroid hormone replacement and growth of children with subclinical hypothyroidism and diabetes. Diabet Med. 1990. -№7(4)., P. 299-303.

2. Salerno M, Capalbo D, Cerbone M, De Luca F. Subclinical hypothyroidism in childhoodcurrent knowledge and open issues. Nat Rev Endocrinol., 2016. - №12(12)., P.734-746 


\title{
ARTIFICIAL INTELLIGENCE ON THE IDENTIFICATION OF DIABETES- RELATED OSTEOMETABOLIC DISORDERS
}

\author{
Sain Safarova \\ Azerbaijan Medical University, department of Internal disease, $\mathrm{PhD}$, associate professor. \\ Department of Internal Medicine II, Azerbaijan Medical University, PhD, associate professor. Azerbaijan \\ Email: dr.safarovas@gmail.com
}

Introduction: Complications of diabetes mellitus (DM) are of great medical and social importance, as they cause severe disability and premature death of patients with diabetes mellitus. Bone remodeling disorders occurring in diabetes increase the risk of fractures and move the problem of diabetic osteopathy beyond the narrow specialty, making it the subject of extensive scientific research [1-3]. However, osteopathy remains an underestimated complication and is not considered in most diabetes guidelines. The fact that diabetic osteopathy is often asymptomatic leads to the fact that diabetic patients turn their attention to this pathology late and turn to a specialist, as a rule, already having a high degree of progression of this complication. One of the important issues is the timely detection and prediction of bone changes in diabetes mellitus.

The introduction of artificial intelligence technologies (AIT) into clinical practice is one of the main trends in world medicine [4]. AIT and Artificial Neural Networks (ANN) can fundamentally change the criteria for diagnosis and prognosis, which will contribute to the development of new therapeutic approaches, improve the efficiency of medical care and reduce costs [5]. The prospects for using ANN can potentially provide almost limitless technical possibilities. Considering the possibilities of using these technologies in clinical practice, we came to the conclusion that the development and implementation of forecasting systems based on the construction of a model of an intelligent decision support system based on the apparatus of artificial neural networks is able to analyze clinical and laboratory indicators of patients with diabetes mellitus (DM) in order to predict the values of qualitative and quantitative indicators assessing the state of bone tissue.

Patients and methods: The research was conducted from November 2015 to July 2017. A crosssectional study evaluating the data of 98 patients with type 1 diabetes (female: 57, male: 41) and 137 patients with type 2 diabetes (female: 85 , male: 52 ) aged from 40 to 69 years, who have not previously been diagnosed with bone metabolism disorders and osteoporosis was evaluated.

Exclusion criteria: persons previously treated for osteoporosis or having a history of fracture, as well as patients with diseases of the endocrine system, liver and kidneys of a non-diabetic nature, with a history of stage 4-5 diabetic nephropathy. The state of bone formation was judged by the activity of total alkaline phosphatase (ALP) and the content of the aminoterminal propeptide collagen type I (PINP) in blood serum. The level of bone resorption was judged by the content of the Cterminal telopeptide (b-CTx). All patients underwent dual-energy X-ray absorptiometry (DXA) of the lumbar spine (L1-L4) to measure bone mineral density (BMD).

The relationship between the results of laboratory studies and the parameters of bone metabolism was revealed when analyzing the results of this study.The study of the above patient data gave the researchers a list of 30 variables, including the BMD value for each of the patients, which were used to develop of ANN model. All of the variables considered, according to previous medical studies, 


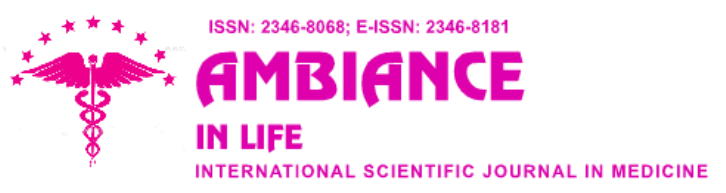

have an impact on the diagnostic and prognosis of osteoporosis. The construction of the neural network was carried out using MATLAB 8.6 (R2015b) [6].

Results: The practical effect of the constructed Artificial neural network model for predicting BMD and values of bone remodeling markers in diabetes based on the analysis of a number of laboratory pa-rameters has been proved. The topology of the model consisted of an input layer, a hidden layer, and an output layer. A model with final ANN parameters was trained using data from $80 \%$ of patients from a randomly selected database. Data from the remaining $20 \%$ of patients were used to verify the results. As a result of the measurement of the absolute error average value, some adjust-ments were made to the model settings to increase its adequacy. Further training is achieved during its practical operation. The learning process continued until errors were reduced for all examples and stopped at the moment when the error in the control sample began to increase. For ease of use, a visual interface was created. Comparative analysis of this approach showed that the values obtained using the neural network diagnostic model reproduce the clinical research picture with a high degree of adequacy, which allows building a diagnostic algorithm for stratification impaired bone metabolism in diabetes.

Conclusion: The constructed neural network model is capable of predicting BMD and values of bone remodeling markers in patients with diabetes mellitus in accordance with the results of their laboratory analyzes. This model can be used to determine which patients should undergo densitometry and analysis of bone remodeling markers to check bone quality and prevent some of the risks associated with osteoporosis.

Keywords: Artificial Neural Network, diabetes, reparative osteogenesis

\section{REFERENCES}

1. Ling O., Rivadeneira F., Zillikens M.C., Oei E. Diabetes, Diabetic Complications, and Fracture Risk // Curr. Osteoporos Rep. 2, 106-115, (2015).

2. Jørgensen H.S., Winther S., Bøttcher M., Hauge E., et al. Bone turnover markers are associated with bone density, but not with fracture in end stage kidney disease: a crosssectional study// BMC Nephrol. 18, 284 , (2017).

3. Abdel-Mageed S. M., Bayoumi A. M., Mohamed E. I. Artificial neural networks analysis for estimating bone mineral density in an Egyptian population: towards standardization of DXA measurements. American Journal of Neural Networks and Applica-tions., 1, 52-56, (2015). doi: 10.11648/j.ajnna.20150103.11

4. Cruz A. S., Lins H. C., Medeiros R. V. A., et al. Artificial intelligence on the identification of risk groups for osteoporosis, a general review. BioMed Eng OnLine. 17, 12, (2018) doi.org/10.1186/s12938-018-0436-1

5. Liu Q, Cui X, Chou YC, et al. Ensemble artificial neural networks alied to predict the key risk factors of hip bone fracture for elders. Biomed Signal Process Control. 21, 146-56, (2015). doi.org/10.1016/j.bspc.2015.06.002.

6. Math Works. MATLAB. www.mathworks.com, (2017). 


\section{A NOVEL PEPTIDE MODULATOR OF THE HUMAN CHANNEL NAv1.5 FROM LATRODECTUS TREDECIMGUTTATUS SPIDER VENOM}

\section{Shynykul Zhanserik}

Master of natural science, teacher, department of fundamental medicine, higher school of medicine, Kazakh National University named after Al-Farabi, Kazakhstan.

Email: shynykul.zhanserik@med-kaznu.com

Spider venom contains a wide repertoire of pharmacologically active compounds, and in the case of some spider species bite, toxins from spider venom can play a fatal role for humans as well as other organisms. Among all the spiders, one could say the bite of Latrodectus tredecimguttatus, known as Black Widow spider, is very dangerous and can even lead to tragic consequences. Especially, voltage-gated sodium channels are responsible for propagating action potentials in excitable cells. Nav1.5 plays a crucial role in the human cardiac muscle, where it enhances the influx of sodium ions via the cell membrane, causing the fast depolarization phase of the cardiac action potential. It is also an important therapeutic target for heart disorders. Various venom-derived peptides have been observed as potential modulators of sodium channels, and these biologically active peptides are an abundant source for pharmacological tools.

The aim of this study was to determine a novel peptide modulators of the human channel $\mathrm{Na}_{\mathrm{v}} 1.5$ in the venom of the Kazakhstan Black Widow spider (L. tredecimguttatus).

The spiders (L. tredecimguttatus) were captured from the South and West regions of Kazakhstan. Venom was extracted to find novel neurotoxins and determine their activity on ion channels. Gel filtration chromatographic technique along with reverse-phase high-pressure liquid chromatography (R-P HPLC) was used for extensive purification. The next step was the functional screening of the purified components applying patch clamp electrophysiology. The functional screening revealed the presence of several ion channel modulators in Black Widow spider venom. Subsequently, MALDITOF and Edman degradation were applied to determine the molecular weight and peptide sequence. Determination of the peptide sequence allowed us to deduce toxin sequences and establish a sequence similarity with other similar toxins.

A novel peptide modulator of the human channel Nav1.5 was isolated and identified as Ltre- 2 . The average molecular mass of the isolated toxin was $3.5 \mathrm{kDa}$.

Further studies of Black widow spider toxins will help to better understand the structure-functional relationships, identification of binding sites on modulated ion channels and also explain the relationship between venom envenomation and symptoms.

\section{REFERENCES}

1. Al Bshabshe, A., Alfaifi, M., \& Alsayed, A. F. (2017). Black widow spider bites from tertiary care center in Saudi Arabia. Avicenna J Med, 7(2), 51-53. doi:10.4103/2231-0770.203606

2. D'Ajello, V., Mauro, A., \& Bettini, S. (1969). Effect of the venom of the black widow spider, Latrodectus mactans tredecimguttatus, on evoked action potentials in the isolated nerve cord of Periplaneta americana. Toxicon, 7(2), 139-144. 


\section{CLINICAL ASPECTS OF PYROPTOSIS}

\section{Tamar Giorgadze, Sophio Giorgadze}

Department of Histology Cytology and Embryology, Tbilisi State Medical University.

Email: giorgadzetamar@gmail.com

Cell death, survival, proliferation and differentiation represent fundamental processes of life. In recent years, multiple novel cell death modalities have been identified and characterized concerning their corresponding stimuli, molecular mechanisms and morphologies. Nowadays we believe that cell death can be roughly divided into necrosis and programmed cell death, the latter one, including apoptosis, oncosis, autophagy, etc., as well as pyroptosis. There has been increasing interest in pyroptosis as a novel form of pro-inflammatory programmed cell death. The complicated mechanism of pyroptosis and its association with the internal environment have been gradually uncovered in recent years. Given its two major effects, cell dysfunction and proinflammation, pyroptosis is thought to plays crucial roles in the pathogenesis and progression of various diseases. Zhaodi Zheng and Guorong Li reported that some molecules or compounds which block pyroptosis may lead to effective treatments for various inflammatory diseases. Some compounds can act as the promising therapeutic drugs for blockage of pyroptosis in inflammatory disease, and others can induce pyroptosis. The way in which we can get a breakthrough in this area remains an issue of utmost importance and requires earnest handling.

Keywords: Pyroptosi; Caspase; Gasdermin; Disiase;

Cell death, survival, proliferation and differentiation represent fundamental processes of life. Cell death plays a pivotal role in embryonic development, maintaining the homeostasis of the organism and eliminating damaged cells. Cell death was initially divided into three types (1): Type I cell death (apoptosis), type II cell death (autophagy) and type III cell death (necrosis). In recent years, multiple novel cell death modalities have been identified and characterized concerning their corresponding stimuli, molecular mechanisms and morphologies. (2) The understanding of cell death has changed a lot through decades. (3). Cells can initiate several distinct programmes of self-destruction, and the nature of the cell death process (non-inflammatory or proinflammatory) instructs responses of neighbouring cells, which in turn dictates important systemic physiological outcomes. (4) Cell death entities can be categorized into programmed or non-programmed cell death based on their signal dependency. Programmed cell death (PCD) is driven by tightly regulated intracellular signal transduction pathways. By contrast, accidental cell death is referred to as non-PCD as a result of unexpected cell injury. (2) Pyroptosis is a form of programmed necrosis, and is morphologically and mechanistically unique form of programmed cell death compared to others, such as apoptosis and autophagic cell death. (5) Pyroptosis is an inflammatory form of programmed cell death that commonly occurs upon the recognition of intracellular pathogens in immune cells (2) and participates in the immune defense mechanisms against intracellular bacterial infections. (6)

Morphologically is characterized by DNA fragmentation, chromatin condensation, cellular swelling with big bubbles, and leakage of cell content, has been proven to have a close relationship with human diseases, such as inflammatory diseases and malignant tumors. (7)

The complicated mechanism of pyroptosis and its association with the internal environment have been gradually uncovered in recent years. (8) Depending on the specific signal pathway and cell 
types, different molecular patterns are secreted to induce pytoptosis (9) Pyroptosis is characterized by the activation of two different types of caspase enzymes - caspase- 1 and caspase-4/5/11, and by the occurrence of a proinflammatory cytokine cascade and an immune response. (6) Also pyroptosis features gasdermin family-mediated membrane pore formation and subsequent cell lysis. (5) Caspase-4, caspase 5 and caspase- 11 are activated by their direct binding to lipopolysaccharides (LPS), while caspase- 1 is mediated by pyroptopic inflammasome sensors $(5 ; 10 ; 11 ; 12)$. The inflammation sensors [e.g., NOD-like receptors (NLRs)] of infected macrophages recognize the flagellin components of pathogens and initiate the formation of multi-protein complex inflammasomes, which subsequently activate caspase-1(13). Upon activation, caspase-1 mediates the membrane pore formation through the cleavage of gasdermin $\mathrm{D}$, allowing the rupture of the cell membrane (14). Generally, GSDMD, the downstream of inflammasome activation, is cleaved by inflammatory caspases (caspase1/4/5/11) to induce pyroptosis, while GSDME is cleaved by apoptotic caspase (caspase3) to cause pyroptotic death (15) Oligomers from gasdermin superfamily - GSDMD and GSDME, are widely studied in pyroptosis. These oligomers form transmembrane pores, allowing the secretion of inflammatory molecules, which disrupt osmotic potential to cause cell swelling with large bubbles blowing from the plasma membrane $(16 ; 17 ; 18)$. Release of several pro-inflammatory intracellular cytokines. (12) including IL-1 $\beta$, IL-18 and HMGB1 $(5,12,19)$ disrupt osmotic potential to cause cell swelling with large bubbles blowing from the plasma membrane $(16 ; 17 ; 18)$. PAMPs and DAMPs are produced along with the pathological process of infectious disease and immune disorders, indicating that both of them have a strong correlation with pyroptosis. (8)

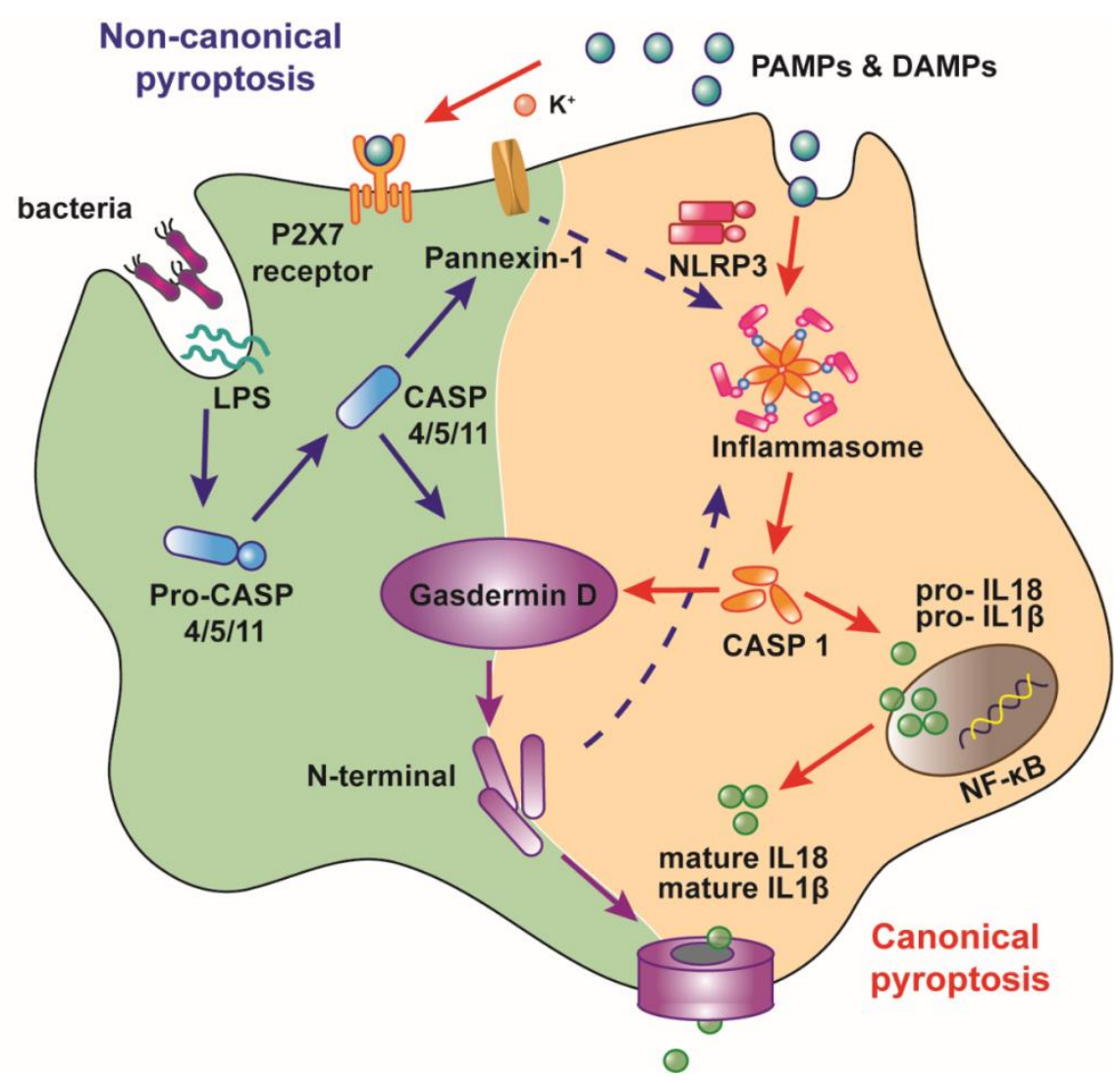

Figure - Pathways of pyroptosis. There are two different pyroptotic pathways. 
The canonical pyroptosis is dependent on the activation of caspase- 1 by inflammasomes, which can recognize PAMPs and DAMPs. Compared to canonical pyroptosis, noncanonical pyroptosis is mediated by the activation of caspase- 1 and caspase- $4 / 5$

Pyroptosis can be evaluated through the visualization of membrane integrity loss by fluorescence microscopy, the detection of interleukin (IL)- $1 \beta$, caspase activation and gasdermin $D$ cleavage by western blot analysis (20).

Given its two major effects, cell dysfunction and proinflammation, pyroptosis is thought to participate in several diseases. $(8 ; 19)$ In general, the balance between chronic inflammatory injury and the healthy immune response of pyroptosis is precisely regulated. When the balance is disrupted, excessive host immune response and massive cell death during pyroptosis can lead to serious disease. Inflammasome activation, which occurs at the onset of pyroptosis, is mechanically believed to be involved in the development and progression of the following diseases: Alzheimer's disease (21) for neurodegenerative disease, it is mainly caused by mass mortality of neurons, partially arising from pyroptosis, leading to nerve system dysfunction. (8) Recent studies show that pyroptosis is implicated in several cardiovascular diseases. In this review, we summarize recent scientific discoveries of pyroptosis's involvement in atherosclerosis, myocardial infarction, diabetic cardiomyopathy, reperfusion injury and myocarditis. (5) The mass mortality of endothelial cells undergoing pyroptosis can result in decreased vascular endothelial function, which is a major cause of cardiovascular disease, intricately though. (8) Zhen Xie and Gang Zhao realized that a variety of bacterial and nonbacterial stimuli (e.g. substance related to autoimmune diseases and cardiovascular and cerebrovascular diseases can drive programmed cell deaths similar to pyroptosis. (3) Abdullah Al Mamun at all demonstrated that pyroptosis plays significant roles in the development of liver diseases, in particular role of pyroptosis based on the molecular and pathophysiological mechanisms in the development of liver diseases (12) Senbo An at all reported that some damaged chondrocytes associated with OA, exhibit morphological changes consistent with pyroptosis, suggesting that this form of regulated cell death may contribute significantly to the pathology of OA. This review summarizes the molecular mechanisms of pyroptosis and shows the critical role of NLRP3 (NLR family, pyrin domain containing 3; NLR refers to "nucleotide-binding domain, leucine-rich repeat") inflammasomes. They also provide evidence describing potential role of pyroptosis in OA, including the relationship with OA risk factors and the contribution to cartilage degradation, synovitis and OA pain. (22). Additionally, cancer development is associated with pyroptosis. As a result of pyroptosis, the release of IL-18/IL-1 $\beta$ and change in innate immunity provide the pro-inflammatory microenvironment necessary for tumor development (6) AIDS, although the association between AIDS and inflammation is apparent, the dysfunction of CD4+ lymphocytes is much more important in its pathology (23).Pyroptosis also plays crucial roles in the pathogenesis and progression of various other diseases: systemic lupus erythematosus (24), cataracts (25), renal ischemia reperfusion injury (26) and diabetes (27).

There has been increasing interest in pyroptosis as a novel form of pro-inflammatory programmed cell death. The mechanism of pyroptosis is significantly different from other forms of cell death in its morphological and biochemical features.(6) Chang Jia at all reported that - new and emerging evidence suggesting that pyroptosis signaling pathways may be potential therapeutic targets in cardiovascular diseases. (5) Zheng and Guorong Li reported that some molecules or compounds which block pyroptosis may lead to effective treatments for various inflammatory diseases. (19) Some compounds can act as the promising therapeutic drugs for blockage of pyroptosis in inflammatory disease, and others can induce pyroptosis. (19) Since a new gasdermin-D (GSDMD) 
protein was identified in 2015, various strategies have been developed to induce pyroptosis for cancer therapy, including ions, small-molecule drugs and nanomaterials. (7) Also, it is feasible to develop targeted medicine to prevent pyroptosis, which may contribute to the treatment of neurodegenerative disease or cardiovascular disease. However, given the characteristics of AIDS and cancer, pyroptosis may be a blind alley for the development of these certain targeted drugs. The way in which we can get a breakthrough in this area remains an issue of utmost importance and requires earnest handling. (8)

\section{REFERENCES}

1. Green DR and Llambi F: Cell death signaling. Cold Spring Harb Perspect Biol.7: pii(a006080)2015.

2. Ge Yan. Mohamed Elbadawi. Thomas Efferth; Multiple cell death modalities and their key features. World Academy Of Sciences Journal. 2; 39-48.2020

3. Zhen Xie, Gang Zhao; Pyroptosis and neurological diseases; Neuroimmunol Neuroinflammation; 1:60-65. 2014

4. Tessa Bergsbaken, Susan L. Fink \& Brad T. Cookson; Pyroptosis: host cell death and inflammation; Nature Reviews Microbiology 7, 99-109|doi:10.1038/nrmicro2070 (February2009)

5. Chang Jia 1, Huanwen Chen 2, Jian Zhang 3, Kailiang Zhou 4, Yingzhi Zhuge 3, Chao Niu 1, Jianxin Qiu 3, Xing Rong 3, Zhewei Shi 5, Jian Xiao 6, Yong Shi 7, Maoping Chu 8; Role of pyroptosis in cardiovascular diseases; International Immunopharmacology; Volume 67, Pages 311-318, February 2019.

6. Wu Jiali, Lin Su, Wan Bo, Velani Bharat, Zhu Yueyong; Pyroptosis in Liver Disease: New Insights into Disease Mechanisms; https://doi.org/10.14336/AD.2019.1216

7. Dr. Dan Wu ; Dr. Sheng Wang; Dr. Guocan Yu ; Prof. Dr. Xiaoyuan Chen; Cell Death Mediated by the Pyroptosis Pathway with the Aid of Nanotechnology: Prospects for Cancer Therapy; https://onlinelibrary.wiley.com/doi/abs/10.1002/ange.202010281. First published: 07 September 2020

8. Yuze Ma, Jiaxuan Jiang, Yuan Gao, Tianshu Shi, Xiaobo Zhu, Kaijia Zhang, Ke Lu, and Bin Xue; Research progress of the relationship between pyroptosis and disease; Am J Transl Res. 2018; 10(7): 2213-2219.

9. Wimmer K., Sachet M., Oehler R. Circulating biomarkers of cell death. Clin. Chim. Acta. 2019;500:87-97. doi: 10.1016/j.cca.2019.10.003.

10. Rathinam VA, Fitzgerald KA. Inflammasome complexes: emerging mechanisms and effector functions. Cell. 2016;165:792-800.

11. Man SM, Kanneganti TD. Regulation of inflammasome activation. Immunol Rev. 2015;265:6-21.

12. Abdullah Al Mamun, Yanqing Wu, Chang Jia, Fahad Munir, Kasfia Jahan Sathy, Tamanna Sarker, Ilma Monalisa, Kailiang Zhou, Jian Xiao; Role of pyroptosis in liver diseases; International Immunopharmacology; Volume 84, July 2020, 106489

13. Bergsbaken T, Fink SL and Cookson BT: Pyroptosis. Host cell death and inflammation. Nat Rev Microbiol. 7:99-109. 2009 
14. Liu X, Zhang Z, Ruan J, Pan Y, Magupalli VG, Wu H and Lieberman J: Inflammasomeactivated gasdermin D causes pyroptosis by forming membrane pores. Nature. 535:153-158. 2016.

15. Ding J., Wang K., Liu W., She Y., Sun Q., Shi J., Sun H., Wang D.-C., Shao F. Pore-forming activity and structural autoinhibition of the gasdermin family. Nat. 2016;535:111-116. doi: 10.1038 /nature 18590

16. He W.T., Wan H. Gasdermin D is an executor of pyroptosis and required for interleukin1beta secretion. Cell Res. 2015;25:1285-1298. doi: 10.1038/cr.2015.139.

17. Kayagaki N., Stowe I.B., Lee B.L., O’Rourke K., Anderson K., Warming S., Cuellar T., Haley B., Roose-Girma M., Phung Q., et al. Caspase-11 cleaves gasdermin D for noncanonical inflammasome signalling. Nat. 2015;526:666-671. doi: 10.1038/nature15541.

18. Rogers C., Fernandes-Alnemri T., Mayes L., Alnemri D., Cingolani G., Alnemri E.S. Cleavage of DFNA5 by caspase-3 during apoptosis mediates progression to secondary necrotic/pyroptotic cell death. Nat. Commun. 2017;8:14128. doi: 10.1038/ncomms14128.

19. Zhaodi Zheng and Guorong Li; Mechanisms and Therapeutic Regulation of Pyroptosis in Inflammatory Diseases and Cancer; Int J Mol Sci. 2020 Feb; 21(4): 1456.

20. den Hartigh AB and Fink SL: Pyroptosis induction and detection. Curr Protoc Immunol: Jul 20, 2018 (Epub ahead of print).

21. Broz P, Dixit VM. Inflammasomes: mechanism of assembly, regulation and signalling. Nat Rev Immunol. 2016;16:407-420

22. Senbo An, Huiyu Hu, Yusheng Li, Yihe Hu; Pyroptosis Plays a Role in Osteoarthritis. Aging and disease 2020, Vol. 11 Issue (5): 1146-1157

23. Slim J, Saling CF. A review of management of inflammation in the hiv population. Biomed Res Int. 2016;2016:3420638.

24. Martinon F, Burns K, Tschopp J. The inflammasome: a molecular platform triggering activation of inflammatory caspases and processing of proIL-beta. Mol Cell. 2002;10:417426

25. Man SM, Karki R, Kanneganti TD. Molecular mechanisms and functions of pyroptosis, inflammatory caspases and inflammasomes in infectious diseases. Immunol Rev. 2017;277:61-75.

26. He WT, Wan HQ, Hu LC, Chen PD, Wang X, Huang Z, Yang ZH, Zhong CQ, Han JH. Gasdermin D is an executor of pyroptosis and required for interleukin-1 beta secretion. Cell Res. 2015;25:1285-1298.

27. Conti B, Park LC, Calingasan NY, Kim Y, Kim H, Bae Y, Gibson GE, Joh TH. Cultures of astrocytes and microglia express interleukin 18. Mol Brain Res. 1999;67:46-52. 


\title{
ABOUT THE DYNAMIC DEVELOPMENT OF THE HEALTH AND PHARMACEUTICAL SECTOR IN AZERBAIJAN
}

\author{
Sevinj Maharramova ${ }^{1}$, Vugar Maharramov ${ }^{2}$ \\ ${ }^{1}$ Azerbaijan Medical University, Department of Pharmacology \\ 2"YurdPharma" LLC, Azerbaijan, Baku
}

Introduction: In the Republic of Azerbaijan in the period 2009-2019 years for the implementation of large-scale measures for the dynamic development of healthcare, decrees were signed on the approval of the State Program for the implementation of the development of the National Strategy in this, mainly, this is strengthening the material and technical base of medical institutions, the use of modern methods of examination and treatment, improving the quality of medical and pharmaceutical services to the population, state regulation of prices for essential medicines, training and improvement of personnel, introduction of compulsory health insurance $[1,2,3]$.

Goal: The purpose of this work was to study the new economic foundations of financing the healthcare system in Azerbaijan, analyze the reforms in healthcare and the pharmaceutical sector, and apply them in practice. To achieve this goal, a number of local regulatory laws, as well as the activities of medical and pharmaceutical services to the population, were studied.

Discussion: During this period, our country has taken extensive measures to solve problems in the field of healthcare and the pharmaceutical sector. The regulatory legal acts governing pharmaceutical activities have been approved. In particular, state regulation of prices in the sphere of circulation of medicines has been introduced to prevent unjustified increases, as well as the application of measures of liability provided for by the legislation of the Republic of Azerbaijan for violation of the pricing procedure for medicines included in the list of essential medicines. In accordance with international standards, the quality control of medicines has been strengthened, the rules for issuing medicines have been improved, new prescription forms have been introduced, and admission to doctors is monitored [4,5].

Keywords: healthcare, pharmaceutical sector, reform analysis

\section{REFERENCES}

1. “Azərbaycan Respublikasında 2009-2015-ci illərdə elmin inkişafi üzrə milli Strategiya”nın və "Azərbaycan Respublikasında 2009-2015-ci illərdə elmin inkişafi üzrə Milli Strategiyanın həyata keçirilməsi ilə bağlı Dövlət Proqramı" nın təsdiq edilməsi haqqında Azərbaycan Respublikasının Prezidentinin Sərəncamı. Bakı şəhəri, 4 may 2009-cu il. №255

2. Azərbaycan Respublikasında səhiyyənin maliyyələşdirilməsi sisteminin islahatı və icbari tibbi sığortanın tətbiqi Konsepsiyası, Azərbaycan Respublikasının Prezidenti İlham Oliyev Qanunvericilik toplusu, Bakı şəhəri, 10 yanvar 2008.

3. "Dərman vasitələri haqqında" Azərbaycan Respublikasının qanunu, Bak1, 2016.

4. V.A.Məhərrəmov, S.H. Məhərrəmova. Müasir səhiyyə və əczaçılıq sektorunda aparılan islahatlar haqq1nda. Azərbaycan Təbabətinin Müasir Nailiyyətləri, Bak1 - 2017, №1, s.141-144 
5. Велиева М.Н., Магеррамов В.А., Атакищизаде С. А., Магеррамова С.Г.

6. Маркетинговые исследования по лекарственному обеспечению в Азербайджанской Республике. European Journal of Biomedical and Life Sciences. Scientific journal, Austria, Vienna - 2017, №1, section 4, pharmaceutical sciences, s.94-98 


\title{
PRIMARY PRODUCT OF PHYTOPLANKTON IN RESERVOIRS OF AZERBAIJAN AND THE DESTRUCTION OF COMMON ORGANIC MATTER
}

\section{Aynur Ansarova}

Azerbaijan Medical University. Department of Medical Biology and Genetics. Azerbaijan. Email: ansarova.aynur@mail.ru

\begin{abstract}
This article is characterized by features of the vegetation and the main representatives of the participants of production-destruction processes, which are the phytoplankton and microbiota in reservoirs located in different climatic zones.

The purpose of the study: Substantiation of the formation of biological productivity by determining the amount of total organic matter destroyed by the primary product synthesized by phytoplankton in the process of photosynthesis in reservoirs.
\end{abstract}

Research materials and methods: Water and silt samples for microbiological research were conducted in the Agstafachay reservoir in 2013 by seasons. Samples in the river were taken from 3 main points - in the territory of Dilijan (A), Krasnoselsk (B) and Ijevan (V) regions of Armenia, and in the reservoir - from 5 stations-places. All samples were taken in accordance with aseptic rules water YI Sorokin batometry and silt-soil with a sterile spatula (in the river), a small QOIN pipe (in the reservoir). Preliminary microbiological analysis was carried out no later than 2 hours after sampling (field-expedition conditions and inpatient-laboratory).

The results of the study: It should be noted that after the creation of reservoirs, initially large amounts of organic matter, biogenic elements in the floodplains enrich the environment, and a real threat to the development of hydrobionts in the basins arises due to the activity of sulfating bacteria. This produces hydrogen sulfide gas $(\mathrm{H} 2 \mathrm{~S})$, which is considered an intermediate product, and this gas causes a massacre like a sharp poison.

The end: The formation of biological productivity was justified by determining the amount of total organic matter destroyed by the primary product synthesized by phytoplankton in the process of photosynthesis in reservoirs.

Keywords: Saprophytic bacteria, physiological groups, speed saprophytes, anthropogenic eutrophication, hypoxia.

\section{REFERENCES}

1. GG Winberg Experience the study of photosynthesis phytoplankton. On the question of the balance of organic matter. Tr. Limnol. Art. in Kosino, 1934, vol. 18, p. 5-24

2. Winberg G.G. Primary production ponds. Publishing house of the Byelorussian Academy of Sciences, Minsk, 1960, 329 p. 
3. Ivatino A.V. The absorption of oxygen, and the degradation of organic matter in the Kuibyshev reservoir. Gidrobiol. Zh., 1973, Vol. 9, number 5, pp. 40-43

4. Manafova A.A. Production of phytoplankton as an indicator of eutrophication Mingachevir water storage. Coll. Scien. tr. Vegetation and the way of its regulation. Baku, "Sience", 1986, p. $8-11$

5. Mammadov V.F. Salmanov MA Anthropogenic eutrophication of Shamkirstorage. Coll. 80th anniversary Musayev MA Tank, 2001, p. 174-176

6. Margolin G.L. Microbiological degradation processes in freshwater. "Nauka", 1989, 119 p.

7. Homeland A.G. Methods of aquatic microbiology. L., "Nauka", 1965, 354 p.

8. Romanenko V.I. Microbiological processes of production and destruction of organic matter in inland waters. L., "Nauka", 1985, 295 p.

9. Romanenko V.I., Kuznetsov S.I. Ecology of freshwater organisms (laboratories. Rukov.), L., "Nauka", 1974, 194 p.

10. Salmanov M.A. Primary production of the Mingachevirwater storage. Dan Az. SSR, 1960, v. 16, № 4, p. 401-405

11. Salmanov M.A. Microbiological study of the Middle and Lower Kura from Borjomi to its confluence with the Caspian Sea. Coll. Biological resources ext. Azerbaijan water storage. Baku, 1975, p. 3-13

12. Salmanov M.A., Ansarova A.H., Primary production of phytoplankton in Varvarawater storage. Inf. Bull. IBIW USSR Academy of Sciences, number 34, 1977, p. 15-18

13. Sorokin Y.I. Primary production and its utilization in marine fresh water. Author. Doctor. diss., 1963, $27 \mathrm{p}$.

14. Sorokin Y.I. On the issue of sampling techniques in the study of marine flora. 1962 Oceanology, t. 11, no. 5, p. 888-897

15. Salmanov M.A., Ansarova A.G., Ismayilov N.M. Abiogenically factors of self-purification of water systems of Azerbaijan. Coll. Actual problems lies. Chemistry and Biology. Ganja, 2016, p. 120-124 


\title{
THE ANTHROPOGENIC ADAPTATION INDEX OF REPTILES IN URBANIZED AREAS OF THE ASHBERON PENINSULA
}

\author{
Aysel Hashimova \\ Azerbaijan Medical University, Department of Medical biology and Genetics. Azerbaijan. \\ Email: aysel-hesimova@mail.ru
}

\begin{abstract}
The strong urbanization of Absheron peninsula highlights the urgency of studying the level of adaptation of reptiles that characterize these areas. Therefore, we have aimed to study the degree of anthropogenic adaptation of each reptile species inhabiting the peninsula. The anthropogenic adaptation index of separate reptiles in the Absheron Peninsula is different in terms of reproductive strategy. Thus, relatively high adaptive anthropogenic intensity is observed in the Caspian bent-toed geckoes (24.5) which are habitats of single-storey buildings, moderately adapted water snakes (17.2), and poorly adapted Mediterranean turtles (10.4). In the mixed-storey residential area, the anthropogenic adaptation were 21.4, 12.8 and 3.7 respectively in geckoes, water snakes and turtles. The anthropogenic adaptation was 0 due to the absence of water snakes and Mediterranean turtles in the residential area with multi-storey buildings, but the Caspian bent-toed gecko was rarely found $(1,3)$. In the area of industrial facilities, the Caspian bent-toed gecko predominates over the reptile species studied, but the level of anthropogenic adaptation in woodlands and control area was much lower.
\end{abstract}

Introduction: The study of anthropogenic adaptation of reptiles in the urbanized areas of the Absheron Peninsula provides a basis for identifying transformation in the biocenosis and monitoring for biodiversity conservation. The main purpose of the study is to determine the regularity of the transformation of reptile fauna and to study the adaptive features of studied reptiles in the urbanized areas of Absheron peninsula. The rapid urbanization of the Absheron Peninsula shows the urgency of solving this problem. Urbanization affects wildlife, especially those that are directly related to the soil, influencing changes in the ecological status and population dynamics of these animals, migration, morphophysiological processes, as well as synanthropy [1,2]. The impact of urbanization on these biological processes of reptiles is primarily due to the fact that the habitat of these animals is occupied by human. The process either causes synanthropy as reptiles acquire new adaptive traits, or leads to a narrowing of their biotope and eventual extinction of those animals.

Materials and methods: The degree of anthropogenic adaptation and population density were determined based on the number of individuals of the species found per $\mathrm{km}^{2}$ of the observed area $[3,4]$. For this purpose, in accordance with the previously adopted herpetological rules, the density was calculated according to the number of individuals encountered in the selected pedestrian routes (transects) in the biotopes [4]. The census of animals was conducted in the months when the studied reptile species were most active (May-June) and during the day, while the census of the Caspian gecko was conducted using a lantern both in the evening and in the dark (around 20-21). Depending on the terrain, linear and zigzag transects (pedestrian routes) were selected for number registration. In open and vacant areas, the transects were linear, while in hilly areas and anthropogenic biotopes they were zigzag-shaped. The length of the transects (LT) was 1000, 500, 200 meters, and the width (BT) 
was $2(1+1) \mathrm{m}$. The density values obtained in the transect areas were calculated to 1 hectare and 1 $\mathrm{km}^{2}$ of biotope area, respectively. The research was conducted in the sharply urbanized areas of the Absheron Peninsula.

The objects of the study are the Mediterranean turtle - Testudo graeca (Linnaeus, 1758), the Caspian bent-toed gecko - Tenuidactylus caspius (Eichwald, 1831) and the water snake - Natrix tessellata (Laurenti 1768). The area of the Absheron Peninsula was first analyzed according to the level of urbanization and studied areas were identified by dividing it into five research and one control areas.

Results and discussion: As it is described in the following table, not all reptiles undergo the same level of anthropogenic adaptation and the degree of anthropogenic adaptation depends primarily on optimality of the studied reptile's living environment. (Table.1)

Table 1 The anthropogenic adaptation index of reptiles in urbanized areas of Absheron Peninsula.

\begin{tabular}{|l|l|l|l|l|}
\hline № & $\begin{array}{l}\text { Studied species } \\
\text { Research } \\
\text { areas }\end{array}$ & $\begin{array}{l}\text { Caspian bent-toed } \\
\text { gecko }\end{array}$ & Water snake & $\begin{array}{l}\text { Mediterranean } \\
\text { turtle }\end{array}$ \\
\hline I & Single-storey residental areas & 24,5 & 17,2 & 10,4 \\
\hline II & Mixed-storey residental areas & 21.4 & 12,8 & 3,7 \\
\hline III & Multi-storey residental areas & 1,3 & 0 & 0 \\
\hline IV & Industrial areas & 11,9 & 2.4 & 1,2 \\
\hline V & Woodlands & 4,8 & 7,9 & 12,6 \\
\hline VI & Control area & 1,2 & 18,5 & 12,8 \\
\hline
\end{tabular}

Comparing the above-mentioned areas with the non-urbanized control area, it becomes clear that the following three zones can be distinguished according to the degree of reproductive activity of the studied reptiles species:

1. The zone of high reproductive activity includes I and V areas

2. Areas with moderate levels of reproductive activity includes II and IV areas

3. A zone with weak or no reproductive activity includes the III area.

In the non-urbanized control area, the rate of reproductive activity has been taken to be $100 \%$, as there is no interference with the natural environment, or rather the process of urbanization has not taken place. The population density of the Caspian bent-toed gecko shows that in the area of high reproductive activity ( I and V zones) there were observed 28 bent-toed geckoes per $\mathrm{km}^{2}$. However, due to the lack of urbanization the absence of anthropogenic factors, especially the construction of residential buildings and fences in the control area (VI), the number of the Caspian bent-toed gecko is probably 6-7 individuals. The reason for that is the lack of favorable conditions for survival and feeding of the Caspian bent-toed gecko in these areas. It should be noted that this number is not stable in all selected residental areas of the peninsula and varies depending on seasonal and anthropogenic influences.

On the other hand, because these studied species are cold-blooded animals, they go to hibernation during the winter and do not show any activity. In this regard, the population density of common water snakes is relatively high around Lake Jeyranbatan, on the shores of the Caspian Sea and along the Samur-Davachi canal (22 on average per $\mathrm{km} 2$ ), but low in the central semi-desert areas of the peninsula (9 individuals). Observations show that the population density of Mediterranean turtles is lower in the urbanized areas of the peninsula (areas II, III and IV), -8 individuals per $\mathrm{km}$, but in the non-urban areas and in the control area is relatively high (14-15 individuals. In all cases, as a result of anthropogenic factors, the natural habitats of studied reptiles are being captured by human or their 
areas are becoming increasingly narrow and limited. The degree of anthropogenic adaptation on the peninsula is not the same for all reptiles living here and differs from each other. These quantitative indicators show that the degree of anthropogenic adaptation is directly correlated with reproductive activity. In other words, if anthropogenic adaptation is successful in urban areas then the reproductive activity is also high.

Conclusion: Finally, we can come to a conclusion that the anthropogenic adaptation index is different in separate reptiles depending on their living area. In all cases, as a result of anthropogenic factors, the natural habitats of studied reptiles are being captured by human or their living areas are becoming increasingly narrow and limited. The degree of anthropogenic adaptation on the peninsula is not the same for all reptiles living here and differs from each other. These quantitative indicators show that the degree of anthropogenic adaptation is directly correlated with reproductive activity. In other words, if anthropogenic adaptation is successful in urban areas then the reproductive activity is also high.. In view of the above, at a time when the peninsula is experiencing strong urbanization, all species of wild fauna, including reptiles, must be strictly protected. According to urban planning laws, species in need of human care should be relocated to safer areas or conditions should be created for their normal migration $[5,6,7]$.

Keywords: urbanization, anthropogenic adaptation, reproductive activity, fauna, biotope, peninsula

\section{REFERENCES}

1. Najafov J.A., Hashimova A. R. The formation of reptile fauna in strongly urbanized territories of Absheron Peninsula in Azerbaijan. Ecology of urbanized territories, Moscow2017, №4,- p.11-15.

2. Najafov J.A., Hashimova A. R. The population density of background reptiles in urbanized territories of Absheron Peninsula in Azerbaijan Problems of Regional Ecology , Moscow 2019 ,№ 3, -c.9-13.

3. Berejnoy O.A., Barbashova Z.I. To the method of determining the absolute number of reptiles by route counting in biotopes of the arid zone. Kiev University. 5th All-Union Herpetological Conference. Ashgabad -1981 p.18 and p.50

4. Romanov V.V., Maltsev I.V. Research methods of ecology of terrestrial vertebrates: Quantitative surveys. Tutorial. 2005, p.71

5. Ushakov V.A. The ways of herpetofauna formation in urbanized areas. Abstracts of reports. Herpetology issues. Leningrad - 1985. -p. 131-132.

6. Ushakov V.A. About the protection of herpetofauna in urbanized areas. The first conference of herpetologists of the Volga region. Togliatti, 1995. - p. 56.

7. Chernousova N.F. The number dynamics of small mammals in urbanized areas. Novosibirsk: Siberian ecological journal. - 2010. - vol. 17. - № 1. - p. 149-156. 


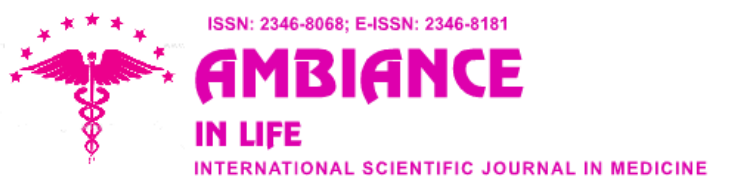

\title{
INFLUENCE OF PERIODONTAL TREATMENT ON PRETERM BIRTH: SYSTEMATIC REVIEW AND META ANALYSIS
}

\author{
Zh. Oralkhan, G. Zhurabekova, S. Abzalieva \\ Department of fundamental medicine, Higher school of medicine, Faculty of medicine and health care, Al-farabi Kazakh \\ National University. Email: ojebecca@gmail.com
}

\begin{abstract}
Background: Preterm birth is considered as the main cause neonatal mortality and morbidity[1]. The rate of preterm birth ranges from $5 \%$ to $18 \%$ of babies born in different countries[2].However, prevent, predict and delay this health condition is almost unsuccessful[2]. Millions of babies are born preterm and this number is rising[2]. Infectious diseases and local and systematic inflammation is most contributing factor to multifactorial etiology of this health condition[3]. The pregnant women are more susceptible to periodontal disease as it is the most prevalent chronic infectious disease in adult population[4]. There are 57 health condition related to periodontitis[5]. The physical and hormonal alternation make the pregnant women more vulnerable to the periodontal disease. Relatively high prevalence of periodontitis during pregnancy found in different population, especially socio-economically disadvantaged women[4]. Periodontitis found to be a risk indicator for preterm birth outcome[6].Clinical trails were conducted to assess the effect of periodontal treatment during pregnancy on reducing these outcomes[7-25].
\end{abstract}

Objective: To assess the effect of different periodontal interventions during pregnancy on preterm birth outcome.

Methods: A systematic review was conducted according to PRISMA guidelines[26], searching Cochrane Library, Pubmed and Embase databases up to 10 December, 2020. PICOS (Population, Intervention, Comparison and Outcomes, study design) framework was used as a search strategy tool. Intervention include scaling and root planning (SRP), Control oral hygiene instructions (OHI), Inclusion criteria were studied in pregnant women, including randomized controlled trials with the aim of assessing the effect of any periodontal treatments on preterm birth outcomes. Main outcome was perform birth $(<37$ gestational week). The data were extracted from two authors and statistical analyses carried out using Review Manager (RevMan).

Results: Twenty randomized controlled trials involving 7759 participants were included in this study. Periodontal treatment during pregnancy was associated with significantly decreased risk of preterm birth $\left[\mathrm{N}=7335 ; \mathrm{RR}=0.78(0.64-0.96) ; \mathrm{p}=0.02 ; \mathrm{I}^{2}=60 \%\right]$.

Conclusion: Periodontal treatment during pregnancy reduces the risks of preterm birth outcome. 


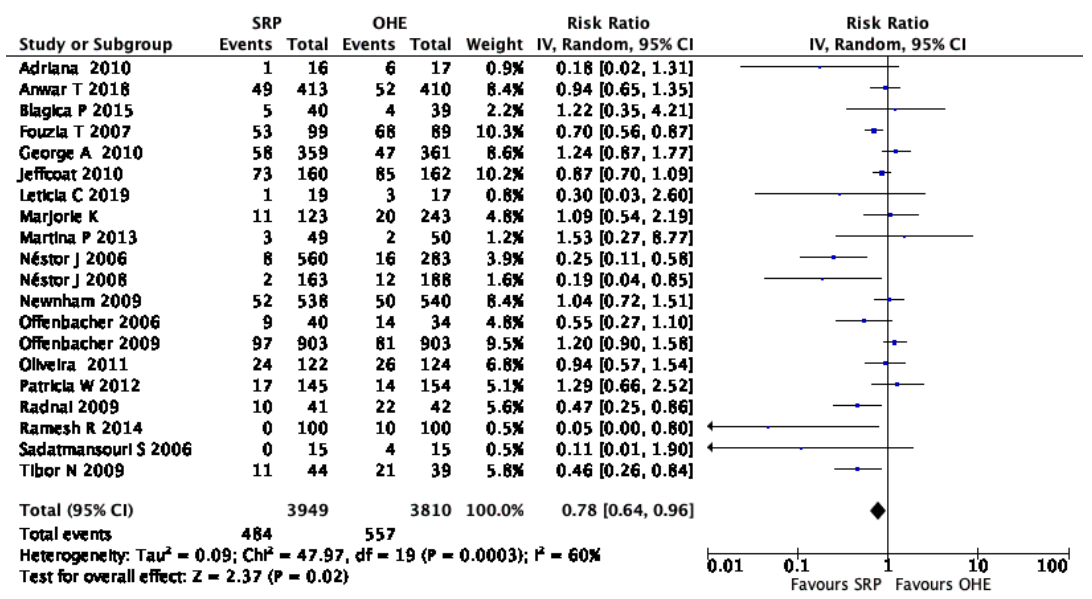

Figure. Forest plots of summary crude risk ratios in the association between periodontal treatment during pregnancy and pre- term birth (PTB, <37 weeks).

\section{REFERENCE}

1. Goldenberg RL, Culhane JF, Iams JD, et al. Epidemiology and causes of preterm birth. Lancet 2008;371:75-84.

2. Chawanpaiboon S, Vogel JP, Moller AB, Lumbiganon P, Petzold M, Hogan D, Landoulsi S, Jampathong N, Kongwattanakul K, Laopaiboon M, Lewis C, Rattanakanokchai S, Teng DN, Thinkhamrop J, Watananirun K, Zhang J, Zhou W, Gülmezoglu AM. Global, regional, and national estimates of levels of preterm birth in 2014: a systematic review and modelling analysis. Lancet Glob Health. 2019 Jan;7(1):e37-e46.

3. Gldenberg RL, Hauth JC, Andrews WW. Intrauterine infection and preterm delivery. N Engl J Med 2000;342(20):1500-7.

4. Nazir M, Al-Ansari A, Al-Khalifa K, Alhareky M, Gaffar B, Almas K. Global Prevalence of Periodontal Disease and Lack of Its Surveillance. ScientificWorldJournal. 2020 May 28;2020:2146160

5. Monsarrat P, Blaizot A, Kemoun P, Ravaud P, Nabet C, Sixou M, et al. Clinical research activity in periodontal medicine: a systematic mapping of trial registers. J Clin Periodontol 2016;43:390-400.

6. Bobetsis YA, Barros SP, Offenbacher S. Exploring the relationship between periodontal disease and pregnancy complications. J Am Dent Assoc. 2006 Oct;137 Suppl:7S-13S.

7. Caneiro-Queija L, López-Carral J, Martin-Lancharro P, Limeres-Posse J, Diz-Dios P, BlancoCarrion J. Non-Surgical Treatment of Periodontal Disease in a Pregnant Caucasian Women Population: Adverse Pregnancy Outcomes of a Randomized Clinical Trial. Int J Environ Res Public Health. 2019 Sep 27;16(19):3638.

8. Merchant AT, Sutherland MW, Liu J, Pitiphat W, Dasanayake A. Periodontal treatment among mothers with mild to moderate periodontal disease and preterm birth: reanalysis of OPT trial data accounting for selective survival. Int J Epidemiol. 2018 Oct 1;47(5):16701678.

9. Penova-Veselinovic B, Keelan JA, Wang CA, Newnham JP, Pennell CE. Changes in inflammatory mediators in gingival crevicular fluid following periodontal disease treatment in 
pregnancy: relationship to adverse pregnancy outcome. J Reprod Immunol. 2015 Nov;112:110.

10. Reddy BV, Tanneeru S, Chava VK. The effect of phase-I periodontal therapy on pregnancy outcome in chronic periodontitis patients. J Obstet Gynaecol. 2014 Jan;34(1):29-32

11. Reddy BV, Tanneeru S, Chava VK. The effect of phase-I periodontal therapy on pregnancy outcome in chronic periodontitis patients. J Obstet Gynaecol. 2014 Jan;34(1):29-32

12. Weidlich P, Moreira CH, Fiorini T, Musskopf ML, da Rocha JM, Oppermann ML, Aass AM, Gjermo P, Susin C, Rösing CK, Oppermann RV. Effect of nonsurgical periodontal therapy and strict plaque control on preterm/low birth weight: a randomized controlled clinical trial. Clin Oral Investig. 2013 Jan;17(1):37-44.

13. Sant'Ana AC, Campos MR, Passanezi SC, Rezende ML, Greghi SL, Passanezi E. Periodontal treatment during pregnancy decreases the rate of adverse pregnancy outcome: a controlled clinical trial. J Appl Oral Sci. 2011 Apr;19(2):130-6

14. Effcoat M, Parry S, Sammel M, Clothier B, Catlin A, Macones G. Periodontal infection and preterm birth: successful periodontal therapy reduces the risk of preterm birth. BJOG. 2011 Jan;118(2):250-6.

15. Oliveira AM, de Oliveira PA, Cota LO, Magalhães CS, Moreira AN, Costa FO. Periodontal therapy and risk for adverse pregnancy outcomes. Clin Oral Investig. 2011 Oct;15(5):609-15.

16. Macones GA, Parry S, Nelson DB, Strauss JF, Ludmir J, Cohen AW, Stamilio DM, Appleby D, Clothier B, Sammel MD, Jeffcoat M. Treatment of localized periodontal disease in pregnancy does not reduce the occurrence of preterm birth: results from the Periodontal Infections and Prematurity Study (PIPS). Am J Obstet Gynecol. 2010 Feb;202(2):147.e1-8.

17. Newnham JP, Newnham IA, Ball CM, Wright M, Pennell CE, Swain J, Doherty DA. Treatment of periodontal disease during pregnancy: a randomized controlled trial. Obstet Gynecol. 2009 Dec;114(6):1239-48.

18. Offenbacher S, Beck JD, Jared HL, Mauriello SM, Mendoza LC, Couper DJ, Stewart DD, Murtha AP, Cochran DL, Dudley DJ, Reddy MS, Geurs NC, Hauth JC; Maternal Oral Therapy to Reduce Obstetric Risk (MOTOR) Investigators. Effects of periodontal therapy on rate of preterm delivery: a randomized controlled trial. Obstet Gynecol. 2009 Sep;114(3):5519.

19. Novák T, Radnai M, Gorzó I, Urbán E, Orvos H, Eller J, Pál A. Prevention of preterm delivery with periodontal treatment. Fetal Diagn Ther. 2009;25(2):230-3.

20. Radnai M, Pál A, Novák T, Urbán E, Eller J, Gorzó I. Benefits of periodontal therapy when preterm birth threatens. J Dent Res. 2009 Mar;88(3):280-4.

21. Tarannum F, Faizuddin M. Effect of periodontal therapy on pregnancy outcome in women affected by periodontitis. J Periodontol. 2007 Nov;78(11):2095-103.

22. Barnes CM. Treatment of periodontal disease and the risk of preterm birth. Pract Proced Aesthet Dent. 2007 Mar;19(2):118.

23. Adatmansouri S, Sedighpoor N, Aghaloo M. Effects of periodontal treatment phase I on birth term and birth weight. J Indian Soc Pedod Prev Dent. 2006 Mar;24(1):23-6.

24. Jeffcoat MK, Hauth JC, Geurs NC, Reddy MS, Cliver SP, Hodgkins PM, Goldenberg RL. Periodontal disease and preterm birth: results of a pilot intervention study. J Periodontol. 2003 Aug;74(8):1214-8. 
25. López NJ, Smith PC, Gutierrez J. Periodontal therapy may reduce the risk of preterm low birth weight in women with periodontal disease: a randomized controlled trial. J Periodontol. 2002 Aug;73(8):911-24.

26. Offenbacher S, Lin D, Strauss R, McKaig R, Irving J, Barros SP, Moss K, Barrow DA, Hefti A, Beck JD. Effects of periodontal therapy during pregnancy on periodontal status, biologic parameters, and pregnancy outcomes: a pilot study. J Periodontol. 2006 Dec;77(12):2011-24.

27. Moher D, Shamseer L, Clarke M, et al. Preferred reporting items for systematic review and meta-ana- lysis protocols (PRISMA-P) 2015 statement. Syst Res. 2015;4:1. 


\title{
DOUBLE BREAKING OF DNA THREADS AND GASTRIC CANCER
}

\author{
Anar Tulyaeva1, Gulmira Zhurabekova², Erbol Bekmukhambetov ${ }^{1}$, Erbolat Iztleuov ${ }^{1}$, Aidana \\ Tautanova ${ }^{3}$ \\ ${ }^{1}$ Department of Oncosurgery, Department of Oncology, West Kazakhstan Marat Ospanov Medical University, \\ Kazakhstan. \\ ${ }^{2}$ Department of fundamental Medicine, Higher School of Medicine. Al Farabi Kazakh National University, Kazakhstan. \\ ${ }^{3}$ Department of scientific and analytical work West Kazakhstan Marat Ospanov Medical University, Kazakhstan. \\ Email: Dekart_85@mail.ru
}

\begin{abstract}
Relevance: Gastric cancer all over the world is ranked 4th in morbidity and 2nd in mortality [1], which is one of the most important social problems of society.

GC is a complex disease that causes factors of environmental and host factors, causing factors that contribute to high mortality of gastric cancer, including its silent course, late clinical manifestations and underlying biological and genetic heterogeneity.

Given the tacit and aggressive nature of gastric cancer, patients seek medical help in advanced stages. Modern science, having the opportunity to study methods for the study of oncological pathology, requires the search for diagnostic methods and the introduction of new personalized methods and monitoring in the treatment of oncological diseases.

Phosphorylation of histone H2AX on Serine IY residues with the endpoint Carboxyl (which produces $\mathrm{yH} 2 \mathrm{AX}$ ) is a sensitive marker for DNA double-strand break (DSB) repair. Double-strand DNA breaks cause severe damage that can cause genomic instability, resulting in cancer [2,3]

[4] Diseases of a person with defects in these processes often exhibit a predisposition to cancer [5]. A key component in DNA repair is the histone $\mathrm{H} 2 \mathrm{AX}$ protein, which rapidly becomes phosphorylated at Serine IY residues from the carboxyl endpoint (Carboxyl endpoint) (Serina c-IY) in order to form $\mathrm{yH} 2 \mathrm{AX}$ at the appropriate sites of the DB. Within 30 minutes after DB formation, a large number of $\mathrm{yH} 2 \mathrm{AX}$ molecules form in chromatin around the site of decomposition, forming a focus where proteins involved in DNA repair and accumulation of chromatin remodeling are accumulated [6] This Amplification enables to detect individual DB with an anti-yH2AX antibody.

Diagnosis of $\mathrm{yH} 2 \mathrm{AX}$ focus formation can be a means of monitoring cancer progression and treatment [7].
\end{abstract}

Purpose of the research: Study of the breaking of two strand chains of the DNA by the $\mathrm{yH} 2 \mathrm{AX}$ method on the AKLIDES® apparatus.

Materials and methods: Pilot project. Cross-case control studies. Random sampling. Patients with a verified diagnosis of gastric cancer $(\mathrm{N} 24)$, in the control group participants who do not have a diagnosis of gastric cancer (N 22). The average age of patients with gastric cancer was 56.04 [52.50: 59.58], 56.21 in the control group [52,42:60,01]. All patients were first identified with a pathomorphologically confirmed diagnosis of gastric cancer, of any stage, who had not yet received treatment from the oncological profile. The control group included conditionally healthy people.

The study was conducted from July 2018 to December 2019 at the West Kazakhstan Marat Ospanov Medical University Medical Center. 
Method for assessing the repair of DNA double-strand breaks in blood lymphocytes by indirect immunofluorescence analysis using the $\mathrm{gH} 2 \mathrm{AX}$ foci system on the AKLIDES ${ }^{\circledR}$ apparatus (Germany / Medipan).

Retraining was carried out according to the methodology: After obtaining blood in a volume of 9 $\mathrm{ml}$, add $6 \mathrm{ml}$ of the fractionating agent (C) to the tubes for diluting the patient's sample. We centrifuge at RT, 1200x g, $20 \mathrm{~min}$. Then carefully remove the white band of peripheral mononuclear cells (PBMCs) using an Epindorf $1000 \mu \mathrm{L}$ pipette and transfer to another dilution tube. Dilute 1: 1 with PBS buffer (B I) and shake gently 3-4 times. Then we centrifuge the suspension (CT, 300xg, 10 min). Carefully remove the liquid fraction with a vacuum pump and add $2 \mathrm{ml}$ of PBS (B I), centrifuge the suspension (CT, 250xg, 10 min, maximum brake). Repeat the procedure twice, then to count the cells prepared dilute the cell suspension with buffer (B1) 1:10 in a test tube. Subsequent dilution with the cell dye $(\mathrm{J})$ in a 1: 1 ratio, we count the cells in $10 \mu \mathrm{l}$ of the cell suspension, in the counting cell. For seeding cells $2.0 * 106$ cells / $\mathrm{ml}$ (set value), the required volume of the cell suspension is calculated. Next, the volume of cell suspension required for the cultivation of inoculation of cells is diluted with PBS buffer (BI) to the required total volume in a glass dish and before each collection, to preserve the cells, is thoroughly mixed manually. $50 \mu$ of cell suspension is applied to each application site of the 6- hole carrier. After fixation, 6-hole object carriers (A) are washed for 3x10 min in PBS buffer (BI) in a dyebath on a shaker (150-300 rpm). Subsequently, to permeabilize the cells, the 6-hole object carrier is immersed in a cold dye bath with an ice-cold permeabilizing solution (D) for 5 minutes at a temperature of $4^{\circ} \mathrm{C}$. Then, the 6-hole object carrier are washed for 3x10 min in BSA / PBS buffer (BII / BI) in a dye bath on a shaker (150-300 rpm). Subsequently, a solution of secondary antibodies (E II) is added to each hole and kept protected from light for 1 hour at room temperature. Add a small drop of the coating agent $(\mathrm{G})$ to each well and place a cover glass $(\mathrm{H})$ on top, avoiding the formation of air bubbles. Subsequent analysis - hole carriers of the object using the $\mathrm{gH} 2 \mathrm{AX}$ foci system on the AKLIDES ${ }^{\circledR}$ apparatus.

Technical difficulties: During the retraining (which takes 10-12 hours), there was a reduced number of cells in lymphocytes in patients with gastric cancer compared to conventionally healthy people.

The design and protocol of the study were approved at a meeting of the local bioethical expert commission at the Marat Ospanov ZKMU (Protocol No. 24 of 03.10.17)

To compare the independent two groups, the nonparametric Mann-Whitney U test was used. The calculated values of the Mann-Whitney U-test were compared with the critical values at a given level of significance $\mathrm{p}<0.005$. The calculations were performed using the Statistica.10 software (Dell Technologies, Round Rock, Texas, USA), as well as the SPSS.v.25 software.

Results and its discussion: Statistically significant differences were found in patients with GC in the number of breaks of two DNA chain breaks $(\mathrm{p}=0.01)$, and it should be noted that the diameter of the breaks differs much more in patients with gastric cancer $(p=0.04)$. also has differences $(p=0.03)$. In other cellular parameters, statistically significant differences were not revealed.

Based on Table 1, we can conclude that there are practically no differences in the number of nuclei with hotbeds, apoptotic cells, positively stained foci cells.

Conclusion: Double-stranded DNA breaks are the main cause of genomic instability that subsequently causes cancer. The study of DNA double-strand breaks using the gH2AX foci system 
on the AKLIDES ${ }^{\circledR}$ apparatus requires further in-depth study, since determining the degree of induction of double-strand breaks can help in monitoring the effectiveness of cancer treatment.

\begin{tabular}{|c|c|c|c|c|c|c|c|c|c|c|}
\hline \multicolumn{11}{|c|}{ Mann-Whitney U test for variables of 2 independent groups. The noted criteria are significant at the $\mathrm{p}<.05000$ level } \\
\hline & $\begin{array}{c}\text { Sum } \\
\text { Rank - } \\
\text { Group 1 }\end{array}$ & $\begin{array}{l}\text { Sum Rank - } \\
\text { Group } 2\end{array}$ & $\mathbf{U}$ & $\mathbf{Z}$ & $\begin{array}{c}\mathrm{p}- \\
\text { level }\end{array}$ & $\begin{array}{l}\mathrm{Z}- \\
\text { adjus } \\
\text { ted. }\end{array}$ & $\begin{array}{c}\mathrm{p}- \\
\text { level }\end{array}$ & $\begin{array}{c}\mathrm{N}- \\
\text { Group } \\
1\end{array}$ & $\begin{array}{c}\mathrm{N}- \\
\text { Group } \\
2\end{array}$ & $\begin{array}{l}\text { 2-sided - } \\
\text { exact } p\end{array}$ \\
\hline Nuclei dia & 517,0000 & 564,0000 & $\begin{array}{l}264, \\
0000\end{array}$ & $\begin{array}{l}0,00 \\
000\end{array}$ & $\begin{array}{l}1,00 \\
0000\end{array}$ & & & 22 & 24 & \\
\hline NucleiBGInt & 538,0000 & 543,0000 & $\begin{array}{l}243 \\
0000\end{array}$ & $\begin{array}{l}0,45 \\
079\end{array}$ & $\begin{array}{l}0,65 \\
2138\end{array}$ & $\begin{array}{l}0,451 \\
37\end{array}$ & $\begin{array}{l}0,65 \\
1726\end{array}$ & 22 & 24 & 0,655148 \\
\hline $\begin{array}{c}\text { Nuclei with } \\
\text { foci }\end{array}$ & 529,0000 & 552,0000 & $\begin{array}{l}252 \\
0000\end{array}$ & $\begin{array}{l}0,25 \\
288\end{array}$ & $\begin{array}{l}0,80 \\
0357\end{array}$ & $\begin{array}{l}0,252 \\
93\end{array}$ & $\begin{array}{l}0,80 \\
0321\end{array}$ & 22 & 24 & 0,802254 \\
\hline $\begin{array}{l}\text { Apoptotic } \\
\text { cells }\end{array}$ & 477,0000 & 604,0000 & $\begin{array}{l}224 \\
0000\end{array}$ & $\begin{array}{l}- \\
0,86 \\
860\end{array}$ & $\begin{array}{l}0,38 \\
5064\end{array}$ & $\begin{array}{l}- \\
0,868 \\
79\end{array}$ & $\begin{array}{l}0,38 \\
4962\end{array}$ & 22 & 24 & 0,388630 \\
\hline Foci overall & 628,0000 & 453,0000 & $\begin{array}{l}153 \\
0000\end{array}$ & $\begin{array}{l}2,42 \\
989\end{array}$ & $\begin{array}{l}0,01 \\
5104\end{array}$ & $\begin{array}{l}2,431 \\
17\end{array}$ & $\begin{array}{l}0,01 \\
5051\end{array}$ & 22 & 24 & 0,014086 \\
\hline Foci dia & 424,0000 & 657,0000 & $\begin{array}{l}171, \\
0000\end{array}$ & $\begin{array}{l}- \\
2,03 \\
407\end{array}$ & $\begin{array}{l}0,04 \\
1945\end{array}$ & $\begin{array}{l}- \\
2,393 \\
06\end{array}$ & $\begin{array}{l}0,01 \\
6709\end{array}$ & 22 & 24 & 0,041138 \\
\hline FociInt mean & 579,0000 & 502,0000 & $\begin{array}{l}202, \\
0000\end{array}$ & $\begin{array}{l}1,35 \\
238\end{array}$ & $\begin{array}{l}0,17 \\
6254\end{array}$ & $\begin{array}{l}1,352 \\
84\end{array}$ & $\begin{array}{l}0,17 \\
6107\end{array}$ & 22 & 24 & 0,177968 \\
\hline Cluster & 610,5000 & 470,5000 & $\begin{array}{l}170, \\
5000\end{array}$ & $\begin{array}{l}2,04 \\
507\end{array}$ & $\begin{array}{l}0,04 \\
0849\end{array}$ & $\begin{array}{l}2,045 \\
70\end{array}$ & $\begin{array}{l}0,04 \\
0787\end{array}$ & 22 & 24 & 0,038936 \\
\hline Foci mean & 460,0000 & 621,0000 & $\begin{array}{l}207 \\
0000\end{array}$ & $\begin{array}{l}- \\
1,24 \\
243\end{array}$ & $\begin{array}{l}0,21 \\
4078\end{array}$ & $\begin{array}{l}- \\
1,242 \\
66\end{array}$ & $\begin{array}{l}0,21 \\
3993\end{array}$ & 22 & 24 & 0,216330 \\
\hline $\begin{array}{l}\text { Foci mean } \\
\quad+\mathrm{Cl}\end{array}$ & 483,0000 & 598,0000 & $\begin{array}{l}230 \\
0000\end{array}$ & $\begin{array}{l}- \\
0,73 \\
666\end{array}$ & $\begin{array}{l}0,46 \\
1327\end{array}$ & $\begin{array}{l}- \\
1,063 \\
64\end{array}$ & $\begin{array}{l}0,28 \\
7493\end{array}$ & 22 & 24 & 0,464994 \\
\hline pos. cells & 515,5000 & 565,5000 & $\begin{array}{l}262 \\
5000\end{array}$ & $\begin{array}{l}- \\
0,02 \\
199\end{array}$ & $\begin{array}{l}0,98 \\
2456\end{array}$ & $\begin{array}{l}- \\
0,021 \\
99\end{array}$ & $\begin{array}{l}0,98 \\
2452\end{array}$ & 22 & 24 & 0,973947 \\
\hline $\begin{array}{c}\text { Foci } \\
\text { mean+LowIn } \\
t\end{array}$ & 509,5000 & 571,5000 & $\begin{array}{l}256, \\
5000\end{array}$ & $\begin{array}{l}- \\
0,15 \\
393\end{array}$ & $\begin{array}{l}0,87 \\
7665\end{array}$ & $\begin{array}{l}- \\
0,153 \\
96\end{array}$ & $\begin{array}{l}0,87 \\
7639\end{array}$ & 22 & 24 & 0,870278 \\
\hline $\begin{array}{c}\text { Foci } \\
\text { mean+LowIn } \\
t+C l\end{array}$ & 548,0000 & 533,0000 & $\begin{array}{l}233 \\
0000\end{array}$ & $\begin{array}{l}0,67 \\
069\end{array}$ & $\begin{array}{l}0,50 \\
2416\end{array}$ & $\begin{array}{l}0,672 \\
04\end{array}$ & $\begin{array}{l}0,50 \\
1557\end{array}$ & 22 & 24 & 0,506040 \\
\hline $\begin{array}{c}\text { pos. cells } \\
\text { LowInt }\end{array}$ & 521,0000 & 560,0000 & $\begin{array}{l}260 \\
0000\end{array}$ & $\begin{array}{l}0,07 \\
696\end{array}$ & $\begin{array}{l}0,93 \\
8652\end{array}$ & $\begin{array}{l}0,076 \\
98\end{array}$ & $\begin{array}{l}0,93 \\
8640\end{array}$ & 22 & 24 & 0,939257 \\
\hline
\end{tabular}

Table № 1 

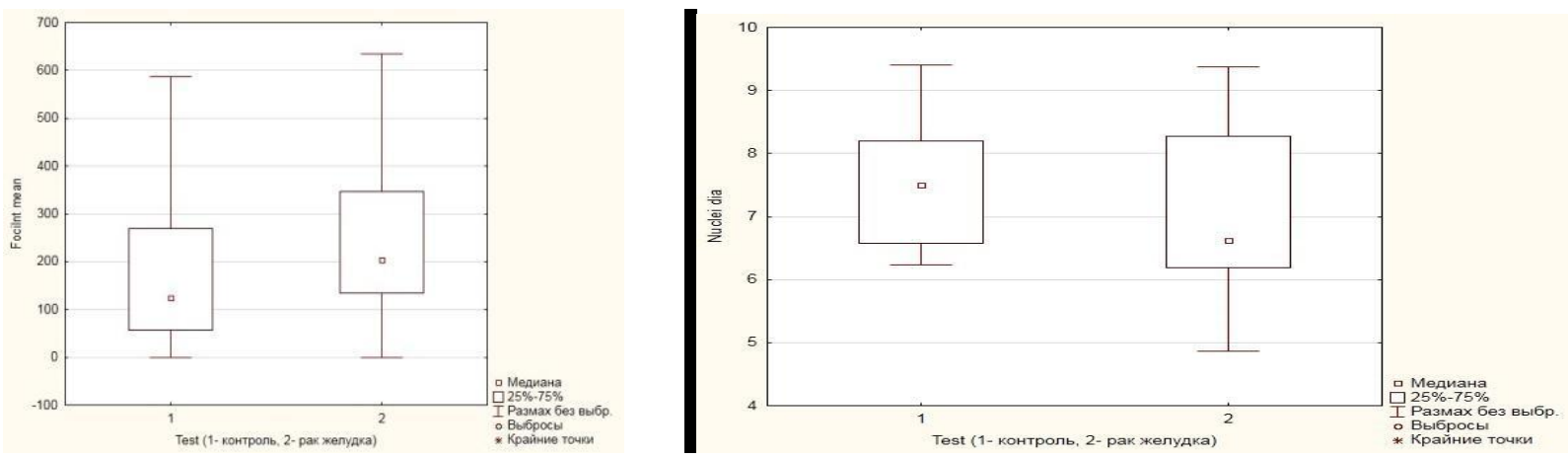

\section{Graph №1}

\section{REFERENCES}

1. Ferlay J, Ervik M, Lam F, Colombet M, Mery L, Piñeros M, Znaor A, Soerjomataram I, Bray F (2018). Global Cancer Observatory: Cancer Today. Lyon, France: International Agency for Research on Cancer. Available from: http://gco.iarc.fr/today/data/factsheets/cancers/7Stomach-fact-sheet.pdf [accessed 10 April 2020]

2. McKinnonPJ, CaldecottKW. DNA strand break repair and human genetic disease. Annu Rev Genomics Hum Genet. 2007; 8:37-55.

3. Jeggo PA, Lobrich M. DNA double-strand breaks: their cellular and clinical impact? Oncogene. 2007; 26:7717-7719.

4. HakemR. DNA-damagerepair; thegood, thebad, andtheugly. EMBOJ. 2008; 27:589-605.

5. O'DriscollM, GenneryAR, SeidelJ, ConcannonP, JeggoPA. An overview of three new disorders associated with genetic instability: LIG4 syndrome, RS-SCID and ATR-Seckel syndrome. DNARepair (Amst). 2004; 3:1227-1235.

6. RogakouEP, BoonC, RedonC, BonnerWM. Megabase chromatin domains involved in DNA double-strand breaks in vivo. JCellBiol. 1999; 146:905-916).

7. Sedelnikova OA, Bonner WM. $\gamma \mathrm{H} 2 \mathrm{AX}$ in cancer cells: a potential biomarker for cancer diagnostics, prediction and recurrence. CellCycle. 2006; 5:2909-2913. 


\title{
HYPERPHENYLALANINEMIA: CASE REPORT
}

\section{Gulmira Zharmakhanova ${ }^{1}$, Victoria Kononetc ${ }^{2}$, Lyazzat Syrlybayeva ${ }^{3}$, Eleonora Nurbaulina ${ }^{4}$, Lyazzat Baikadamova ${ }^{5}$}

\author{
${ }^{1}$ Head of the department of molecular biology and medical genetics, West Kazakhstan Marat Ospanov Medical \\ University, Kazakhstan, Email: gmzh@list.ru \\ ${ }^{2}$ Lecturer of the department of molecular biology and medical genetics, West Kazakhstan Marat Ospanov Medical \\ University, Kazakhstan, Email: micropaleontolog@yandex.kz \\ ${ }^{3}$ Senior lecturer of the department of molecular biology and medical genetics, West Kazakhstan Marat Ospanov Medical \\ University, Kazakhstan, Email: humana-west@mail.ru \\ ${ }^{4}$ Senior lecturer of the department of general medical practice, West Kazakhstan Marat Ospanov Medical University, \\ Kazakhstan, Email:eleonora_71@bk.ru \\ ${ }^{5}$ Obstetrician-gynecologist, Medical Center, Kazakhstan, Email: baikadamovalyazat@gmail.com
}

Background: Hyperphenylalaninemia (HPA) is a group of autosomal recessive diseases caused by impaired metabolism of the essential amino acid phenylalanine (Phe), which enters the human body with protein food [1]. HFA combines several genetically heterogeneous forms of phenylalanine metabolism disorders similar in clinical features: classical phenylketonuria (PKU), caused by phenylalanine-4-hydroxylase (PAH) deficiency and hyperphenylalaninemia (HPA), associated with tetrahydrobiopterin $\left(\mathrm{BH}_{4}\right)$ metabolic disorders [2]. The pterin-dependent form of hyperphenylalaninemia accounts for about $2 \%$ of all cases of HPA. These conditions are caused by a deficiency of enzymes involved in the synthesis or reduction of tetrahydrobiopterin $\left(\mathrm{BH}_{4}\right)$, which is a PAH cofactor, as well as tyrosine hydroxylase and tryptophan hydroxylase $[3,4]$. Currently, several genetically heterogeneous forms of $\mathrm{BH}_{4}$-deficient HPA are known: type A, 6pyruvoyltetrahydropterine synthase (PTPS) deficiency, type $\mathrm{B}$, guanosine triphosphate cyclohydrolase $1(\mathrm{GTPCH})$ deficiency, type $\mathrm{C}$, dihydropterine reductase (DHPR) deficiency, type D, pterin-4a- $\alpha$-carbinolamine dehydratase (PCBD) deficiency, DOPA-dependent dystonia caused by sepiapterin reductase (SPR) deficiency and HPA without tetrahydrobiopterin deficiency, caused by mutations in the DNAJC12 gene encoding the JDP1 protein [5, 6]. Pterin-dependent forms of HPA have clinical manifestations similar to classical PKU. In these forms, the main role in the pathogenesis is played by a severe deficiency in the neurotransmitters of the catecholamine and serotonin series, which makes isolated diet therapy meaningless and requires different approaches to treatment. The complex of treatment for such patients includes $\mathrm{BH}_{4}$ or its synthetic analogs [3-5].

Clinical case: Child A., a boy, was admitted to the clinic at the age of 11 months due to a pronounced delay in psychomotor development. From the anamnesis: the child from the second pregnancy, the pregnancy was uneventful, was born on time with a weight of $3240 \mathrm{~g}$, a length of 54 $\mathrm{cm}$. The parents are not consanguineous, they are healthy. They have one healthy child. During the examination under the program of mass screening of newborns, A. was diagnosed with hyperphenylalaninemia. The level of phenylalanine in the blood was $940 \mu \mathrm{mol} / \mathrm{L}$. Based on this, he was diagnosed with phenylketonuria and prescribed diet therapy with restriction of protein intake. With strict adherence to a low-protein diet, the level of phenylalanine in the blood during the first two months of life decreased insignificantly, to $610 \mu \mathrm{mol} / \mathrm{L}$, and then decreased to normal values, 75-100 $\mu \mathrm{mol} / \mathrm{L}$. Upon admission to the clinic, there is a deficiency of body weight and height, moderately pronounced microcranium, light hair color. Neurological status: symptoms of muscular 
dystonia are determined - moderate hypotonia of the trunk muscles and hypertonicity of the muscles of the extremities, tendon reflexes are increased. When the position of the body changes, there is an increase in muscle tone, tremor, and oculogyric crises. Poorly holds the head, does not turn on the stomach, grabs the toy and holds it for a short time. In the clinical analysis of blood and urine pathological changes were not revealed. In the study of the concentration of amino acids in the blood by tandem mass spectrometry, the level of phenylalanine was $102 \mu \mathrm{mol} / \mathrm{L}$. The lack of positive dynamics in the psychomotor development of the child while following a low-protein diet, which ensures the maintenance of a normal level of phenylalanine in the blood, made one suspect a cofactor form of hyperphenylalaninemia. In order to diagnose $\mathrm{BH}_{4}$ - deficient HPA, a sensitivity test to sapropterin dihydrochloride was carried out, which gave a positive result. The patient is recommended to undergo a molecular genetic study - sequencing of the PTS, QDPR, GCH1, PCBD, SPR, DNAJC12 genes to determine the specific type of $\mathrm{BH}_{4}$ - deficient HPA.

\section{REFERENCES}

1. Blau N., van Spronsen F.J., Levy H.L. Phenylketonuria// Lancet. 2010. V.376. №9750. P.1417-27.

2. Van Wegberg A.M.J., MacDonald A., Ahring K., Bélanger-Quintana A. et al. The complete European guidelines on phenylketonuria: diagnosis and treatment// Orphanet J Rare Dis. 2017. V.12. №1.P.162. doi: 10.1186/s13023-017-0685-2.

3. Blau N, Hennermann JB, Langenbeck U, Lichter-Konecki U. Diagnosis,classification, and genetics of phenylketonuria and tetrahydrobiopterin (BH4) deficiencies. Mol Genet Metab 2011;104:S2-S9.

4. Trujillano D., Perez B., González J., Tornador C., Navarrete R. et al. Accurate molecular diagnosis of phenylketonuria and tetrahydrobiopterin-deficient hyperphenylalaninemias using high-throughput targeted sequencing// Eur J Hum Genet. 2014. V.22. №4. P.528-34. doi: 10.1038/ejhg.2013.175. Epub 2013 Aug 14.

5. Opladen T., Hoffmann G.F., Blau N. An international survey of patients with tetrahydrobiopterin deficiencies presenting with hyperphenylalaninaemia// J Inherit Metab Dis. 2012. V.35. №6. P.963-73.

6. Gundorova P., Stepanova A.A., Kuznetsova I.A., Kutsev S.I., Polyakov A.V. Genotypes of 2579 patients with phenylketonuria reveal a high rate of $\mathrm{BH} 4$ non-responders in Russia //PLoS One. 2019. V.14. №1. P.e0211048. doi: 10.1371/journal.pone.0211048. eCollection 2019. 


\title{
PROBLEM OF MEDICAL STUDENTS WHICH PREVENT FORMING A HEALTHY LIFESTYLE
}

\author{
${ }^{1}$ Nazigul Zhumagazhiyeva, ${ }^{2}$ Amir Kappassov \\ ${ }^{1}$ Student of $4^{\text {th }}$ course, «General medicine», E-mail: zhumagazhiyevanazigul@ gmail.com \\ ${ }^{2}$ Student of $4^{\text {th }}$ course, «General medicine», E-mail: amirkappasov@ mail.ru
}

Background: The study of the problems of forming a healthy lifestyle is due to the increase and change in the nature of loads on students in connection with:

-the introduction of new educational programs that require a large proportion of students ' selftraining;

-emotional pressure - the case of a pandemic causes fear and limits the communication of students; many students do not live in a family, work part-time;

-increasing risks of man-made nature (worldwide digitalization, introduction of IT technologies);

These loads provoke negative changes in the state of health of students.

Purpose: 1) Identify the main factors that prevent the formation of a healthy lifestyle of medical students.

2) Suggest optimal ways to solve stressful situations that prevent the formation of a healthy lifestyle for medical students.

Materials and methods of research: Cross-sectional single-stage study.

A voluntary anonymous questionnaire of 3rd course students of the "Semey Medical University" Non-Commercial Joint-Stock Company was conducted.

To the smartphones of 623 students of the $3^{\text {rd }}$ course of the School of Medicine sent a message with questions of the questionnaire.

253 students (40.6\% of the total number) aged from 18 to 25 years took part in the survey.

Results of research: According to the survey, the formation of a healthy lifestyle among medical students is largely hindered by the behavior of the older generation. Therefore, by imitating the behavior of parents, the growing generation acquires negative and harmful habits, attitudes to lifestyle and behavior issues. In addition, it is important to note that the expression of recommendations on healthy habits in an edifying form often causes a reaction of protest.

It is very important to note that the introduction of a student to a healthy lifestyle should begin with the formation of health motivation.

Conclusions: Therefore, in order to develop measures to increase motivation for a healthy lifestyle among students of the non-profit joint-stock company "Semey medical University", it is necessary to develop and implement a comprehensive program for health promotion and solving various stressful situations that hinder the observance of a healthy lifestyle at The University.

According to the results of the survey, it is recommended that the main directions in solving the above problems should be:

Conduct a survey of students to find out bad habits and develop measures to help students get rid of them (together with a psychologist); 
Control the quality / nutritional value of meals in the University canteen and review the menu, organize food outlets in the non-profit joint-stock company "Semey medical University".

\section{REFERENCES}

1. ruhttps://gigabaza.ru/doc/90773.html

2. Druzhilov S.A. Healthy lifestyle as an appropriate activity of a person // Modern research and innovation. - 2016. — № 4. - p. 654-648. 


\section{ПРЕНАТАЛЬНАЯ ДИАГНОСТИКА ХРОМОСОМНЫХ БОЛЕЗНЕЙ У ПЛОДА}

Айтекин Гасанова

Азербайджанский медицинский университет, кафедра медицинской биологии и генетики, Азербайджан.

Email: aytakin_hasanova@mail.ru

Пренатальная диагностика: раздел медицинской генетики, направленный на раннее выявление и профилактику наследственных заболеваний и врожденных пороков развития , в последние годы получила особенно бурное развитие. В обзоре суммированы наиболее важные достижения пренатальной диагностики, достигнутые благодаря широкому внедрению новых молекулярно-генетических технологий, позволяющих с высокой точностью анализировать нарушения микроструктуры хромосом, генов и продуктов их экспрессии. Новые технологии, существенно увеличившие возможности пренатальной диагностики и делающие ее более эффективной и безопасной, позволяют значительно снизить естественный генетический груз наследственной патологии в популяции. Вместе с тем внедрение этих методов создает определенные организационные и методические трудности, делает необходимым вносить коррективы в устоявшийся за много лет традиционный алгоритм пренатальной диагностики.

Как совместить очевидные преимущества новых диагностических методов и подходов с существующим алгоритмом пренатальной диагностики? Как при этом не растерять уже имеющийся положительный опыт врачей-акушеров, генетиков, лаборантов, привыкших к определенной последовательности действий в сложной иерархии алгоритмов основных и вспомогательных служб пренатальной диагностики? Основные современные молекулярногенетические технологии в пренатальной диагностике включают: молекулярную диагностику хромосомных болезней, микроделеционный анализ с помощью микрочипа (сравнительная геномная гибридизация - array CGH) , доимплантационную диагностику хромосомных и генных болезней , неинвазивную пренатальную диагностику (НИПД) хромосомных и генных болезней методом секвенирования ДНК плода в крови матери (секвенирование нового поколения - NGS), упредительное генетическое тестирование для выявления мутаций у супругов при планировании беременности(1).

Все большей популярностью в пренатальной диагностике пользуется метод КФ-ПЦР для массовой диагностики (скрининга) частых хромосомных аномалий у плода. Следует отметить, что при своей кажущейся простоте, как показывает наш многолетний опыт, применение метода требует не только соответствующего оборудования (секвенатора типа ABI 3600), но, что особенно важно, специалиста высокой квалификации с большим опытом молекулярногенетической диагностики.

Решающим успехом молекулярно-генетического подхода в пренатальной диагностике явился метод количественной флюоресцентной ПЦР (КФ-ПЦР), позволяющий резко повысить производительность пренатальной диаг-ностики наиболее частых хромосомных болезней (трисомии по хромосомам 21, 13, 18, численные нарушения гоносом), на долю которых приходится свыше 95 \% всей хромосомной патологии у новорожденных(2). Диагностика возможна на любом сроке беременности и практически на любом материале плода, полученном при инвазивных вмешательствах. Секвенатор ABI 3100, который чаще всего используется для этих целей, позволяет анализировать 12-16 образцов в день и получать результаты уже на следующие сутки. Важно, что скорость анализа позволяет использовать 
метод КФ-ПЦР для получения информации о рас-пространенных хромосомных аномалиях у плода в поздние сроки беременности . Данный метод внедрен в пренатальную диагностику нашего клиники еще в 2008 г. В нашей лаборатории этим методом уже проведено около 500 пренатальной диагностики, и почти в 300 случаях у плодов были выявлены хромосомные нарушения (5). Высокие производительность и чувствительность, рутинное использование для анализа клеток амниотической жидкости, а при необходимости - любых клеток плода, относительно низкая себестоимость по сравнению со стандартным кариотипированием не оставляют сомнения в необходимости его широкого использования в пренатальной диагностике. За последние несколько лет метод получил широкое распространение благодаря появлению отечественных коммерческих наборов, необходимых для молекулярного маркирования анализируемых хромосом. Оригинальные наборы на соответствующие полиморфные локусы разработаны также и в нашей лаборатории. Согласно нашему опыту, на каждую анализируемую хромосому важно иметь наборы олигопраймеров, достаточных для анализа не менее 5-6 полиморфных сайтов, что обычно гарантирует информативность теста(3).

Однако в некоторых случаях все полиморфные аллели гомологичных хромосом могут оказаться одинаковыми, что делает их неинформативными и затрудняет диагностику методом КФ-ПЦР. Другим осложнением являются необычные варианты (аллели) маркерного локуса, наличие которых требует дополнительного исследования геномов родителей. Трудности диагностики касаются также численных нарушений половых хромосом и хромосомного мозаицизма. Таким образом, несмотря на кажущуюся простоту, следует еще раз отметить что, анализ методом КФ-ПЦР должен выполняться специалистом, имеющим навык в молекулярногенетических исследованиях. Учитывая селективность теста, следует также помнить, что он не заменяет стандартного кариотипирования плода, позволяющего выявить аномалии числа и структуры всех хромосом набора. В этой связи мы считаем более оправданным применение данного теста в группе риска женщин с измененными показателями сывороточных маркерных белков, а при наличии УЗ-маркеров предпочитаем использование стандартного кариотипирования. Вместе с тем, согласно рекомендациям Европейского цитогенетического общества возможно использование метода КФ-ПЦР и при наличии УЗ-маркеров хромосомной патологии у плода (4).

Ключевые слова: Пренатальная диагностика ; амниотическая жидкость; хромосомные аномалии; врожденные пороки развития КФ-ПЦР.

\section{ЛИТЕРАТУРА}

1. Мутовин Г.Р. Основы клинической генетики. М. Высшая школа, 2001,с.204. Г.М.Савельева, О.Б.Панина, Л.Г.Сичинава и др. Пренатальный период и его значение в развитии плода и новорожденного //Акушерство и гинекологии.2004.-No2.-C.60-62

2. Савельева Г.М. Достижения и нерешенные вопросы перинатальной медицины// Российский вестник акушера-гинеколога. 2003.-T.3.-No2.-С.62-65.

3. Hassanzadeh Nazarabadi M, Raoofian R, Abutorabi R. Balanced Chromosomal Translocations of Parents in Relation to Spontaneous Abortions. J Sci. 2005;16:P.203-208

4. A.T.Hasanova İndications for prenatal karyotyping. Modern information, measurement and control systems: Problems and perspectives July 01-02,Baku- 2019 ; ADNSU. P.99-102 


\section{PRIMARY EWING'S SARCOMA OF THE NASAL CAVITY IN PEDIATRIC PRACTICE}

\section{Bekisheva Aigul1, Makhneva Anna², Bulegenova Minira3, Abyov Galyjan³, Remkulova Mahabbat $^{3}$}

${ }^{1}$ Pathomorphologist of the Clinical Diagnostic Laboratory, Scientific Center of Pediatrics and Pediatric Surgery JSC, Kazakhstan, Email: skorpion_72_27@mail.ru

${ }^{2}$ Pathomorphologist of the Clinical Diagnostic Laboratory, Scientific Center of Pediatrics and Pediatric Surgery JSC, Kazakhstan, Email: dandelionwine @inbox.ru

${ }^{3}$ Head of the Department of Clinical Diagnostic Laboratory, Scientific Center of Pediatrics and Pediatric Surgery JSC, Doctor of Medical Sciences, Kazakhstan, Email:mbulegenova@yandex.kz

${ }^{3}$ Pathomorphologist of the Clinical Diagnostic Laboratory, Scientific Center of Pediatrics and Pediatric Surgery JSC, Kazakhstan, Doctor pathologist, Email:galymzhan_abuov@mail.ru

${ }^{3}$ Oncologist, Scientific Center of Pediatrics and Pediatric Surgery JSC, Doctor oncologist, Kazakhstan, Email:mahabbat.zhanerke@mail.ru

\section{ABSTRACT}

Introduction: Ewing's sarcoma (ES) is an aggressive tumor occuring more frequently in childhood and adolescence, mainly observed during the first three decades of life. Microscopically consists of small round cells, with a high nuclear cytoplasmic index, originating from primitive neuroectodermal cells. Most often such tumor occurs in early childhood or adolescence. [1]

Ewing's sarcoma refers to tumors of the bone tissue : the limbs, ribs, and pelvic bone, but also it may occur in soft tissues, which means any localization in the human body. Among extra-skeletal localities, ES rarely occurs in the head and neck (2-3\% of all ES) and extremely rare in the nasal cavity or paranasal sinuses [1,2,3]. Diagnosis the primary of ES nasal localization is complex and mainly depends on histopathological research, as visual diagnostic methods (x-ray, CT, MRI) do not identify the type of tumor. MRI examination of tumors of such localization may suggest a malignant nature, so further differential diagnosis should exclude the following: malignant lymphoma, rhabdomyosarcoma, moderately differentiated carcinomas, and ES. These tumors have common radiological features, so they require additional research $[4,5]$.

From abovementioned, the following clinical case of primary Ewing's sarcoma in the nasal cavity in a 14-year-old girl seemed to be interesting . The patient complained on the difficulty of breathing, swelling in the right half of the nose wing. MRI showed a large neopasm of the facial skull on the right (pterygoid and subterranean fossa, right half of the nose, nasopharynx, latticed bone and paranasal sinuses). Histological examination of the samples revealed a solid neoplastic tissue consisting of monomorphic small circular or oval cells with a high nuclear-cytoplasmic index. Some exapnsion of the tumor cells around the vessels was observed, while part of epithelial lining and glandular structures were preserved in the same places. Foci of necrosis and extensive hemorrhages were visualized. The immunohistochemical study with the CD99 antibody showed a total positive membrane reaction with the closure of the stained membranes ( with the presence of membranes ring staining ). The reaction with anti Fli1 revealed total nuclear staining of tumor cells, except for the stromal cells. 
Thus: as primary Ewing's sarcoma affects the sinus tract very rarely, diagnosis of the tumor in this location is difficult. MRI and other visual methods in these cases are not informative, because a number of tumors have common radiological features, that make the differential diagnosis very difficult. In this regard, the pathomorphological study including immunohistochemical research is the main method of diagnosing ES.

\section{REFERENCES}

1. Aldandan A., Almomen A., Alkhatib A., Alazzeh G. Pediatrics Ewing's Sarcoma of the Sinonasal Tract: A Case Report and Literature Review. Hindawi Case Reports in Pathology Volume 2019, (4):1-3

2. Akbay E., Yaldız M., Cevik C. at all. Ewing's sarcoma arising from base of nasal cavity and extending to nasopharynx and oral cavity. Ifa Medical Journal 2015, vol. 2, (1):15.

3. Bo Young Jeong, Seok Won Park, Eo Jin Kim at all. Extraskeletal Primary Ewing's Sarcoma in the Nasal Cavity: A Case Report. J Korean Soc Radiol 2013, 69(2):99-103

4. Coskun BU, Cinar U, Savk H, Basak T, Dadas B. Isolated maxillary sinus Ewing's sarcoma. Rhinology 2005, 43:225- 228

5. Kawabata M, Yoshifuku K, Sagara Y, Kurono Y. Ewing's sarcoma/primitive neuroectodermal tumour occurring in the maxillary sinus. Rhinology 2008;46:75-78 


\section{PROGNOSTIC VALUE OF N-MYC GENE AMPLIFICATION IN PATIENTS WITH NEUROBLASTOMA}

Bahram Zhumadullaev $^{1}$, Zhazira Saduova ${ }^{2}$, Aigerim Uskenbayeva ${ }^{3}$, Gauhar Nurzhanova ${ }^{3}$, Dinara Yeginbergenova ${ }^{4}$, Aru Nazarova $^{5}$

${ }^{1}$ Head of the department of surgery, PhD in Medicine, «Scientific Centre of Pediatrics and children's surgery» Kazakhstan, Email: bahram1967@mail.ru

${ }^{2}$ Resident in the specialty " Pediatric oncology and hematology", «NMU» named after S.D. Asfendiyarov JSC, Kazakhstan, «Scientific Centre of Pediatrics and children's surgery» JSC, Kazakhstan, Email: zhazi-95@mail.ru

${ }^{3}$ Resident in the specialty " Pediatric oncology and hematology", «NMU» named after S.D. Asfendiyarov JSC, Kazakhstan, «Scientific Centre of Pediatrics and children's surgery» JSC, Kazakhstan, Email:auskenbaeva@ mail.ru

${ }^{3} \mathrm{Head}$ of the department of oncohematology 2, «Scientific Centre of Pediatrics and children's surgery» JSC, Kazakhstan, Email: gaukharnur@mail.ru

${ }^{4}$ Resident in the specialty " Pediatric oncology and hematology", «NMU» named after S.D. Asfendiyarov JSC, Kazakhstan, «Scientific Centre of Pediatrics and children’s surgery» JSC, Kazakhstan, Email: d.yeginbergenova@mail.ru ${ }^{5}$ Resident in the specialty " Pediatric oncology and hematology", «NMU» named after S.D. Asfendiyarov JSC, Kazakhstan, «Scientific Centre of Pediatrics and children’s surgery»JSC, Kazakhstan, aru_91_@mail.ru

\section{ABSTRACT}

This work presents the results of studying the prognostic value of the N-MYC gene amplification in patients with neuroblastoma treated according to the European protocol NB-2004. A retrospective analysis of 140 patients who were diagnosed with neuroblastoma from 2013-2019 was carried out at the SCP and PS. When collecting data from 140 patients with neuroblastoma, amplification of the $\mathrm{N}$ MYC gene was found in 26 patients, of which 19 patients died (73\%), 7 patients are alive (survival rate $-27 \%$ ). Amplification of the NMYC gene occurred with the same frequency in boys and girls, $50 \%$ in each group. In children under one year old, there were 6 children (23.1\%), 1-2 years old 12 patients (46.2\%), 2-5 years old 5 children (19.2\%), over 5 years old 3 patients $(11.5 \%)$. In $13(50 \%)$ children, the primary tumor was localized in the adrenal glands, in $11(42 \%)$ - in the retroperitoneal space and in $2(7.7 \%)$ in the mediastinum. In $21(80.8 \%)$ patients with amplification of the N-MYC gene, the disease was diagnosed at stage IV, in 2 cases $(7.7 \%)$ with stage IVs, and $1(3.8 \%)$ case at I, II, III stage of the disease. Thus, patients with N-MYC gene amplification were more often detected at stage IV of the disease and had an unfavorable outcome.The fact of the negative impact of amplification of the N-MYC gene is confirmed in our study. The therapeutic protocol is ineffective in the presence of N-MYC gene amplification (survival - 27\%).

Keywords: Neuroblastoma, NMYC gene amplification, prognosis, children.

\section{Introduction:}

\section{Relevance:}

Neuroblastoma (NB) - an embryonic malignant tumor of childhood, is a common extracranial solid tumor.

Amplification of the N-MYC gene in patients with NB is one of the main indicators of the aggressiveness of the disease, early resistance to chemotherapy, and poor prognosis [1-4]. 
Results: To study the prognostic value of N-MYC gene amplification in patients with NB treated according to the European protocol NB-2004 at the SCP and PS of the city of Almaty, Republic of Kazakhstan from 2013 to 2019.

During data collection, 140 patients with NB were identified; we found amplification of the N-MYC gene in 26 children, 19 of them died (73\%),7 patients are alive (survival rate $-27 \%$ ). Comparative analysis was carried out according to the following parameters: age at the time of diagnosis, gender, stage of the disease, tumor localization. Amplification of the NMYC gene occurred with the same frequency in boys and girls, 50\% in each group. In children under one year old, there were 6 children (23.1\%), 1-2 years old 12 patients $(46.2 \%), 2-5$ years old 5 children (19.2\%), over 5 years old 3 patients $(11.5 \%)$. In $13(50 \%)$ children, the primary tumor was localized in the adrenal glands, in 11 $(42 \%)$ - in the retroperitoneal space and in $2(7.7 \%)$ in the mediastinum. In $21(80.8 \%)$ patients with amplification of the N-MYC gene, the disease was diagnosed at stage IV, in 2 cases (7.7\%) with stage IVs, and $1(3.8 \%)$ case at I, II, III stage of the disease. Thus, patients with N-MYC gene amplification were more often detected at stage IV of the disease and had an unfavorable outcome.

Conclusions: The fact of the negative impact of amplification of the N-MYC gene is confirmed in our study. The therapeutic protocol is ineffective in the presence of N-MYC gene amplification (survival rate $-27 \%$ ).

\section{REFERENCES}

1. B. Zhumadullaev, G. Nurzhanova, B. Baizakova, S. Saliyeva, E.Krivenko, G. Algazyeva, K. Bertaeva, E. Iseeva, M. Remkulova, S. Baiturova, B.Elibaev, a. Bakisheva. G. Batyrkhanova, M. Karazhanova, M. Ensepbayev, D.Kraiomov.. Neuroblastoma Treatment in Kazakhstan: Single Center Experience. Pediatric Blood \&Cancer, 2019; PO140 SIOP19-0390: S610 of S709.

2. Ward E., DeSantis C., Robbins A., Betsy K., Ahmedin J. Childhood and adolescent cancer statistics, 2014. CA Cancer J Clin 2014; 64(2):83-103.

3. Brodeur G. M., Bagatell R. Mechanisms of neuroblastoma regression. Nat Rev Clin Oncol 2014;11(12):704-13.

4. Ambros I.M., Zellner A., Roald B. Amann G., Ladenstein R., Printz D., Gadner H., Ambros P. F.. Tyrrole of ploidy, chromosome 1p, and Schwann cells in the maturation of neuroblastoma. N Engl J Med 1996; 334(23):1505-11. 


\section{НЕСПЕЦИФИЧЕСКИЙ АОРТОАРТЕРИИТ У ДЕТЕЙ: ПРОБЛЕМЫ ПОЗДНЕЙ ДИАГНОСТИКИ И ЛЕЧЕНИЯ}

\section{Райхан Майтбасова}

Доктор медицинских наук, главный научный сотрудник, детский ревматолог, АО «Научный центр педиатрии и детской хирургии, доктор медицинских наук, главный научный сотрудник, детский ревматолог, АО "Научный центр педиатрии и детской хирургии", Казахстан.

Email: rmaytbasova@mail.ru

\section{РЕЗЮМЕ}

Проведен ретроспективный анализ историй болезни 11 детей с неспецифическим аортоартериитом, проходивших обследование и лечение в НЦПДХ в 2010-2020 годы. Анализировали возраст в дебюте, продолжительность болезни на момент исследования, длительность активной фазы, распространенность поражения аорты и ее ветвей, эффективность базисной терапии (БТ) и исходы. Срок постановки диагноза от начала заболевания: от 6-11 мес- 4 (36,4\%), >12 мес - 7 (63,6\%). По локализации: I тип- 9\%, IІа-9\%, IIb-9\%, III-36\%, IV-18\%, V-18\%. В БТ: метипред (стартовые дозы 1,0-1,5, поддерживающие0,5-0,3 мг/кг/сут)+ методжект (15-10мг/м²/нед)-10детей $(90,9 \%)$ и 1 (9,1\%)-в сочетании с циклофосфамидом (пульс-терапия 500 мг/м² х 1 раз/мес 6 мес). В 1 случае оперативное лечение (имплантация стент-графта в брюшной отдел аорты и нефрэктомия справа).

Результаты и обсуждение. Дети были в тяжелом $(9-81,8 \%)$ и в крайне тяжелом $(2-18,2 \%)$ состоянии. Острая фаза отмечалась у $3(27,3 \%)$ и у одного из них артериальная гипертензия (АГ)-200/140 мм.рт.ст. У 2 девочек - вторичная дилатационная кардиомиопатия. Чаще наблюдался III тип-36\%. Терапия была не эффективна у 27,3\% детей в связи с критической окклюзией брюшного, грудного отделов аорты с вторичным сморщиванием почек с потерей функции и злокачественной АГ. Т.о., у детей с НАА выявлены выраженный стеноз/окклюзия аорты и ее ветвей, что свидетельствовало о крайне поздней его диагностике.

Введение: Неспецифический аортоартериит (НАА) в детском возрасте относится к редко встречающимся заболеваниям, что становится причиной поздней диагностики, инвалидизации и летального исхода [1-3]

Цель: анализ своевременности диагностики неспецифического аортоартериита у детей с оценкой эффективности терапии и исхода.

Материалы и методы: Проведен ретроспективный анализ историй болезни детей с НАА (11), проходивших обследование и лечение в НЦПДХ в 2010-2020 годы. Возраст 3-17 лет. Девочек8 (72,7\%), мальчиков-3 (27,3\%), соотношение 3:1. Анализировали возраст в дебюте, продолжительность болезни на момент исследования, длительность активной фазы, распространенность поражения аорты и ее ветвей, эффективность базисной терапии (БТ) и исходы. Срок постановки диагноза от начала заболевания: $>6$ мес- $4(36,4 \%),>12$ мес - 7 (63,6\%). По локализации: I тип- 1 (9,1\%), IIa-1 (9,1\%), IIb-1 (9,1\%), III-4 (36,4\%), IV- 2 (18,2\%), V-2 (18,2\%). В БТ: метипред (стартовые дозы 1,0-1,5, поддерживающие-0,5-0,3 мг/кг/сут)+ 
методжект (15-10мг/м²/нед)-10детей (90,9\%) и 1 (9,1\%)-в сочетании с циклофосфамидом (пульс-терапия 500 мг/м² х 1 раз/мес 6 мес). В 1 случае оперативное лечение (имплантация стент-графта в брюшной отдел аорты и нефрэктомия справа).

Результаты и обсуждение: Дети были в тяжелом (9-81,8\%) и в крайне тяжелом (2-18,2\%) состоянии. Острая фаза отмечалась у $3(27,3 \%)$ и у одного из них артериальная гипертензия (АГ)-200/140 мм.рт.ст. У 2 девочек - вторичная дилатационная кардиомиопатия. Чаще наблюдался III тип (36,4\%). Терапия не эффективна у 27,3\% детей с летальным исходом в связи с критической окклюзией брюшного, грудного отделов аорты с вторичным сморщиванием почек с потерей функции и злокачественной АГ..

Вывод: У детей с неспецифическим аортоартериитом выявлены выраженный стеноз/окклюзия аорты и ее ветвей, что свидетельствовало о крайне поздней его диагностике

\section{ЛИТЕРАТУРА}

1. Лыскина Г.А, Костина Ю.О Диагностика и лечение неспецифического аортоартериит у детей (обзор литературы)

2. Al Abrawi S., Fouillet-Desjonqueres M., David L. et al.. Takayasu arteritis in children. Pediatr Rheumatol, 2008 Sep, 28;6:7.

3. Tullus K., Marks S.D. Vasculitis in children and adolescents: clinical presentation, etiopathogenesis, and treatment. Paediatr Drugs. 2009, 11 (6): 375-380. 


\title{
НЕКОТОРЫЕ РЕЗУЛЬТАТЫ УЧЕНЫХ МГУ И РАН ПО ВОПРОСАМ НАКОПЛЕНИЯ ХИМИЧЕСКИХ ЭЛЕМЕНТОВ В ОРГАНИЗМАХ
}

\author{
${ }^{1}$ Сергей Остроумов, ${ }^{2}$ Сергей Котелевцев, ${ }^{3}$ Евгений Криксунов \\ ${ }^{1}$ Доктор биол.наук, ведущий научный сотрудник лаборатории физхимии биомембран биологического факультета \\ МГУ; \\ ${ }^{2}$ Доктор биол.наук, ведущий научный сотрудник лаборатории физхимии биомембран биологического факультета \\ МГУ; \\ ${ }^{3}$ Член-корреспондент РАН, профессор кафедры ихтиологии биологического факультета МГУ)
}

Аннотация. В данной статье суммированы некоторые результаты исследований ученых МГУ и Российской академии наук, которые изучали накопление химических элементов организмами (на примере некоторых биологических видов). Обобщение результатов проводится в связи с представлениями В.И. Вернадского о биосфере. Учитываются современные проблемы загрязнения окружающей среды. Среди тех химических элементов, данные о которых получены в рассмотренных в статье работах - тяжелые металлы и некоторые другие элементы.

Ключевые слова: биосфера, химическая экология, биогеохимия, геохимия, химические элементы, миграция элементов в биосфере, накопление, биоаккумуляция, металлы, биомасса, растения, животные

\section{ABSTRACT}

In this article, a summation is made of some of research results of scientists of Moscow State University and Russian Academy of Sciences on accumulation of chemical elements by organisms (exemplified by some biological species). The summation of the results is made in connection with concepts of V.I.Vernadsky on the biosphere. The contemporary issues of environmental pollution are taken into consideration. The chemical elements that are considered include heavy metals and some other elements.

Keywords: biosphere, chemical ecology, biogeochemistry, geochemistry, chemical elements, migration of elements in the biosphere, accumulation, bioaccumulation, metals, biomass, plants, animals

Введение: В 2009 году один из соавторов (С.А.О.) был приглашен прочитать лекцию на Всероссийской конференции «Экотоксикология-2009» (на базе Института биохимии и физиологии микроорганизмов им. Г.К. Скрябина РАН), которая затрагивала в том числе проблемы биогеохимии и измерения содержания отдельных химических элементов в биогенном материале. Затем последовали его доклады на Биогеохимических чтениях памяти В.В. Ковальского в Институте геохимии и аналитической химии им. В.И. Вернадского РАН, на Ломоносовских чтениях в МГУ им. М.В. Ломоносова, заседаниях МОИП (Московское общество испытателей природы) и доклады на других форумах. Поэтому возникла на целесообразность подготовки обобщающих материалов.

Цель этой работы: внести вклад в суммирование и систематизацию некоторых публикаций ученых Московского государственного университета имени М.В. Ломоносова (МГУ) и РАН, 
имеющие отношение к упомянутым докладам и лекциям. Данная работа не выходит за рамки этой конкретной и ограниченной задачи и не является ни обзором литературы, ни текстом лекции.

В работе многих поколений ученых творческим стимулом служили и служат труды Владимира Ивановича Вернадского (1863-1945).

В.И. Вернадский заложил основы учения о биосфере в своих публикациях, в том числе в книге «Биосфера», со дня выхода которой из печати прошло уже больше 80 лет. Это учение успешно развивается и обогащается новыми фактами. Концептуальное развитие этого учения происходит значительно медленнее. Теоретические разработки базируются на работе по сбору и анализу новых фактов. Ряд соответствующих публикаций отражен в данной работе (см. Таблицы 1-4).

В работе использованы следующие сокращения: ДАН - Доклады академии наук (научный журнал РАН); ДНОК - динитроортокрезол (пестицид); ДСН - додецилсульфат натрия; ЕС50 эффективная концентрация, вызывающая эффект величиной 50\%; ЖМС - жидкое моющее средство; КПАВ - катионное (катионогенное) поверхностно-активного вещество; ПАВ поверхностно-активное вещество; СПАВ - синтетическое поверхностно-активное вещество; СГМА - сополимер гексена и малеинового альдегида; СМС - синтетическое моющее средство; SDS - додецилсульфат натрия; ТДТМА - тетрадецилтриметиламмоний бромид (катионогенный ПАВ); TX - Тритон X100 (неионогенный ПАВ); ЦТАБ цетилтриметиламмоний бромид;

Некоторые результаты работы по сбору и анализу новых фактов: Анализируя сущность науки, В.И. Вернадский писал: «Научный аппарат из миллиарда миллиардов все растущих фактов, постепенно и непрерывно охватываемых эмпирическими обобщениями, научными теориями и гипотезами, есть основа и главная сила, главное орудие роста современной научной мысли».

Необходимы исследования и накопления веществ в организмах, изучение воздействия веществ на организмы, и анализ обратного воздействия организмов на химизм среды - a именно, воздействия организмов на концентрации веществ в среде.

Наша работа включала в себя исследования в нескольких направлениях, в том числе изучение накопления, концентраций загрязняющих веществ в организмах образцах биогенных материалов.

Отметим также, что исследования в этом и других смежных направлениях - важнейшая часть современной научной базы практической работы по сохранению окружающей среды. Это нашло свое отражение в анализе, проведенном в наших книгах [56-57, 68-69]. В самое последнее время нарастает понимание роли организмов в очищении среды обитания, что делает перспективным изучение их в связи с поиском экотехнологий (в том числе фитотехнологий) для снижения химического загрязнения среды, в том числе водной [33-40, 43-45, 64, 65]. Ниже суммированы некоторые работы автора по накоплению новых фактов. При рассмотрении этих фактов полезно помнить слова М.В. Ломоносова «Один опыт я ставлю выше, чем тысячу мнений, рожденных только воображением».

В.И. Вернадский писал: «Жизнь - живое вещество - поистине является одной из самых могущественных геохимических сил нашей планеты, а вызываемая ею биогенная миграция атомов представляет форму организованности первостепенного значения в строении 
биосферы» (Вернадский, 1965, стр.297). Поэтому необходимы исследования накопление химических элементов в организмах. Эта работа, необходимая сама по себе, представляет интерес и в связи с исследованием биогеохимических потоков в биосфере.

Определенная часть работ ученых МГУ проводилась в содружестве с учеными Российской академии наук (Институт геохимии и аналитической химии, Институт океанологии, Институт биохимии), АН Молдовы и Университета штата Массачусетс (г. Амхерст, США).

Ниже приведены примеры этих исследований. Необходимо еще раз подчеркнуть, что данная публикация не является обзором. Помимо упоминаемых здесь работ есть большое количество ценных исследований и других ученых МГУ, проводимых на многих факультетах, в том числе факультете почвоведения, географическом факультете, геологическом факультете и других факультетах, а также во многих лабораториях и институтах Российской академии наук (PAH).

Примеры работ по определению концентрации химических элементов в организмах: Часть полученных автором результатов по вопросам измерения концентраций химических элементов, накопление веществ в организмах, образцах биомассы и биогенных материалов отражена в нижеследующей таблице 1.

Таблица 1 Примеры работ с участием ученых МГУ по изучению накопление элементов в организмах и их роль в биогеохимических потоках элементов (измерения концентраций химических элементов, накопление веществ в организмах, образцах биомассы и биогенных материалов). Если имя автора для краткости не указано, то автором является С.А.О.

\begin{tabular}{|c|c|}
\hline О результатах работы & Ссылки \\
\hline $\begin{array}{l}\text { Получены новые данные о концентрации и } \\
\text { накоплении нескольких металлов в биомассе } \\
\text { элодеи канадской из пресноводного водоема в } \\
\text { Московской области, проведено сравнение этих } \\
\text { данных с концентрациями металлов в элодее } \\
\text { канадской в другой стране. }\end{array}$ & $\begin{array}{l}\text { Остроумов, С. А., Данилова, В. Н., Хушвахтова, С. Д., } \\
\text { Ермаков, В. В., Тютиков, С. Ф., Тропин, И. В., \& } \\
\text { Котелевцев, С. В. (2016). Содержание химических } \\
\text { элементов, глутатиона и металлотионеинов в элодее } \\
\text { канадской (Elodea canadensis) в связи с } \\
\text { экологическим мониторингом. Экологическая химия, } \\
\text { 25(4), 197-203. }\end{array}$ \\
\hline 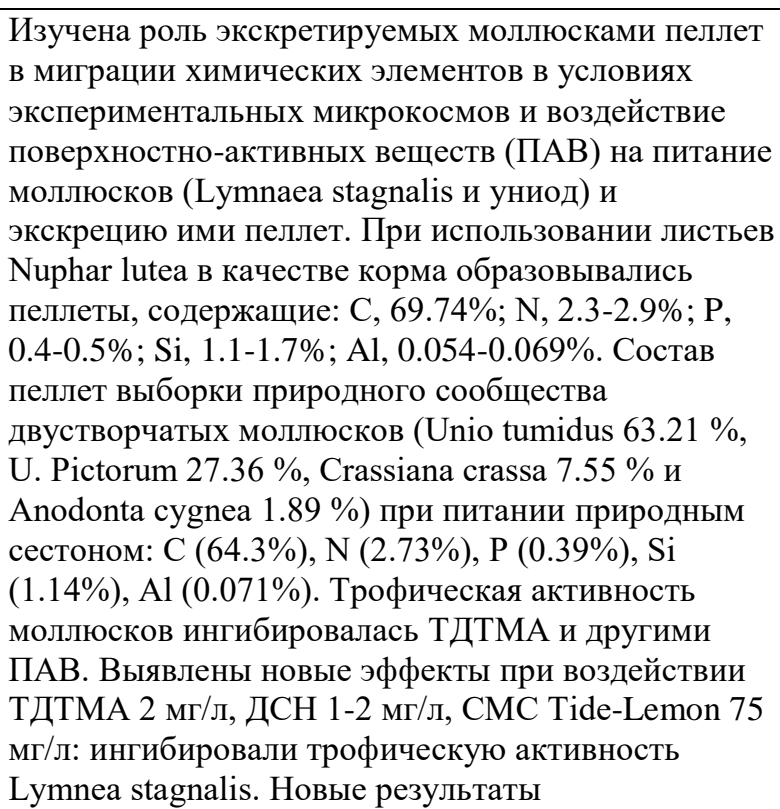 & $\begin{array}{l}\text { Пеллеты моллюсков в биогеохимических потоках С, } \\
\text { N, P, Si, Al // ДАН. 2001. Т. 379. № 3. С. 426-429. } \\
\text { Библиогр. } 12 \text { назв. [Совместно: С.А.О., Колесников } \\
\text { М.П.]. }\end{array}$ \\
\hline
\end{tabular}


свидетельствовали об ингибировании переноса вещества через данное звено трофической цепи и возможности антропогенного нарушения биогеохимических потоков.

Elemental composition $(\mathrm{C}, \mathrm{N}, \mathrm{P}, \mathrm{Si}, \mathrm{Al})$ of pellets formed by mollusks Lymnaea stagnalis feeding on the leaves of Nuphar lutea and Taraxacum officinale; amount (wet weight, dry weight) of pellets formed by L. stagnalis feeding on the leaves of N. lutea and T. officinale; transfer of matter and chemical elements $(\mathrm{C}$, $\mathrm{N}, \mathrm{P}, \mathrm{Si}, \mathrm{Al}$ ) with pellets of freshwater bivalves (unionids Unio sp., etc.) per unit biomass of mollusks and per unit area of the ecosystem of the river; transfer of matte and chemical elements $(\mathrm{C}, \mathrm{N}, \mathrm{P}, \mathrm{Si}, \mathrm{Al})$ with pellets of L. stagnalis per unit biomass of mollusks and per unit area of the ecosystem of the pond. Synthetic surfactants TDTMA $2 \mathrm{mg} / \mathrm{l}$, SDS 1-2 mg/l, detergent Tide-Lemon $75 \mathrm{mg} / \mathrm{l}$ inhibited the trophic activity of $\mathrm{L}$. stagnalis. Percents of food assimilability of taxons of invertebrates, from Rotatoria (48-80) to Diptera (1-3)]. DOI 10.1023/A:1011620817764.

Нов. факты о составе пеллет, о переносе химич. элементов в биогеохим. потоках.

Изучали роль экскретируемых моллюсками пеллет в миграции химических элементов в условиях экспериментальных микрокосмов и воздействие катионного поверхностно-активного вещества (КПАВ, ПАВ) на питание моллюсков (Lymnea stagnalis и унионид) и экскрецию ими пеллет фекалий и псевдофекалий. Показано, что моллюски L. stagnalis экскретируют пеллеты со скорость 4-7 мг (сухого веса) на 1 г сырого веса моллюсков за 72 часа. При использовании листьев Nuphar lutea в качестве корма образовывались пеллеты, содержащие: C, 69,74\%; N, 2,3-2,9\%; P, 0,4-0,5\%; Si, 1,1-1,7\%; Al, 0,054-0,059\%. B присутствии 2 мг/л КПАВ тетрадецилтриметиламмоний бромида (ТДТМА) скорость питания L. Stagnalis снижалась на 27,970,9\%. При этом образование пеллет на 1 г сырого веса L. Stagnalis снижалось на 41,7\% (за период инкубации 72 часа). Состав пеллет выборки природного сообщества двустворчатых моллюсков (Unio tumidus $63,21 \%$, U. pictorum $27,36 \%$, Crassiana crassa 7,55 \% и Anodonta cygnea 1,89 \%) при питании природным сестоном: C (64,3\%), N $(2,73 \%), \mathrm{P}(0,39 \%), \mathrm{Si}(1.14 \%), \mathrm{Al}(0,071 \%)$. Фильтрация ими воды также ингибировалась ТДТМА и другими ПАВ. Это свидетельствовало об ингибировании переноса вещества через данное звено трофической цепи и биогеохимических потоков.
Pellets of some mollusks in the biogeochemical flows of C, N, P, Si, and Al. - Doklady Biological Sciences, 2001. Vol. 379, P. 378-381. Bibliogr. 12. (Translated from: DAN 2001. Vol. 379. No. 3. P. 426-429). ISSN 00124966. [In collaboration: S.A.O., Kolesnikov M.P.]

Biogeochemical role of bivalves: transfer of chemical elements with pellets // Ecol. Studies, Problems, Solutions, 2003, vol. 6. P.16-17 [Совместно: Kolesnikov M.P., S.A.O.].

C.А.О. Моллюски в биогеохимических потоках $(\mathrm{C}, \mathrm{N}$, $\mathrm{P}, \mathrm{Si}, \mathrm{Al})$ и самоочищении воды: воздейсвтие ПАВ // Вестник МГУ. Сер. 16. Биология. 2003 № 1. С.15-24. Табл. Резюме на англ. яз. Библ. 59 назв. [Совместно: С.А.О., Колесников М.П.]. 
Выделены основные биогеохимические блоки или компоненты, концентрации химических элементов в которых имеют существенное значение для биогенной миграции элементов, в том числе: 1) мягкие ткани моллюсков; 2) раковины моллюсков; 3) фекалии; 4) псевдофекалии; 5) слизистые вещества; 6) продукты метаболизма, выделяемые в воду как растворенные в ней вещества. Даны примеры их количественного изучения.

Даны предложения к разработке концепции базы данных для статистической модели оценки роли моллюсков в биогенной миграции элементов, в том числе металлов. Приводится список тех величин и показателей, которые представляют интерес для включения в такую базу данных.

Role of molluscs in water self-purification and the interactions between molluscs and elements, including metals.

Фосфор в мягких тканях Dreissena polymorpha.
С.А.О. О роли моллюсков в биогенной миграции элементов и самоочищении воды. - Ecol. Studies, Hazards, Solutions, 2006, v. 11, с. 77-79, табл. Библиогр. 5 назв. [Совместно: С.А.О., Ермаков В.В., Зубкова Е.И., Колесников М.П., Колотилова Н.Н., Крупина М.В.];

С.А.О. База данных для разработки статистической модели оценки роли моллюсков в биогенной миграции металлов: концепция и разработка элементов теоретических основ. - Ecol. Studies, Hazards, Solutions, 2006, v. 11, c. 79-83, табл. Библиогр. 6 назв. [Совместно: С.А.О., Ермаков В.В., Зубкова Е.И., Колесников М.П., Колотилова Н.Н., Крупина М.В., Лихачева Н.Е.];

Studying the role of molluscs in water self-purification and the interactions between molluscs and elements, including metals, in aquatic environments. - ESHS, 2007, vol. 12, p. 29-32. Bibliogr. 9 refs. [In collaboration: S.A.O., Zubcov E.I., Toderash I.K., Biletchi L.I., Bogonina Z.S., Breahna A., Klyushnikov V.Yu., Kolesnikov M.P., Krupina M.V., Makarov A.S., Munjiu O.V., Railean N., Subernetkii I.V.]

Фосфор в мягких тканях Dreissena polymorpha из Дубоссарского водохранилища. - ESHS, 2007, vol. 12, p. 51-53. [Совместно: Зубкова Е.И., Тодераш И.К., Мунжиу О.В., С.А.О., Богонина 3.С., Шубернецкий И.B.]

Разработка методологии [инкубацию Unio pictorum вели 3,5 мес. в присутствии 13 металлов].

\section{С.А.О. Изучение толерантности моллюсков в} условиях полиметаллического загрязнения воды и длительной инкубации. - ESHS, 2007, vol. 12, p. 7881.

Обобщены данные мировой литературы о содержании цинка в мягких тканях раковин пресноводных и морских моллюсков, даны новые результаты определения цинка в моллюсках, в том числе водных экосистем р. Дон и Молдовы.

Среднее содержание ртути в мягких тканях пресноводных двустворчатых моллюсков Unio pictorum из одной из рек Московской области составило 181.2 нг/л, в раковинах тех же моллюсков - 160.0 нг/г. Уровень концентрации ртути такого же порядка был ранее найден в моллюсках ряда (но не всех) морских экосистем. Кадмий в моллюсках
Цинк в водных моллюсках // Известия АН Молдовы. Науки о жизни. 2007, № 2, с. 102-114, ISSN 1857064Х. [совместно: Тодераш И.К., С.А.О., Зубкова Е.И., Чернышёва И.В., Крупина М.В., Микус А. А., Райлян Н.К., Бряхнэ А.И., Мирон А.А., Кирошка В.В., Мунжиу О.В.].

Изучение содержания ртути в двустворчатых моллюсках. - Экология окружающей среды и безопасность жизнедеятельности = Екологія довкілля та безпека життєдіятельності. №5, 2007, с.79-80. 2 табл. Библиогр. 6 назв. [Совместно: С.A.О., С.Д.Хушвахтова, В.Н. Данилова, В.В. Ермаков].

Изучение взаимодействия кадмия с водными моллюсками в связи с экологическим мониторингом // Вода: технология и экология. 2007. № 3. С. 68-77. Табл. 3. Библиогр. 41 назв. Реф. На русск. и англ. яз. c. 95. [Совместно: С.A.О., Микус А.А.] [=Studying the interaction between cadmium and aquatic molluscs in connection with ecological monitoring. - Water: 


\begin{tabular}{|c|c|}
\hline & $\begin{array}{l}\text { Technology and Ecology. 2007. No. 3. p. 68-77. Tables, } \\
\text { Bibliogr. } 41 \text { refs. (in Rus.) Abstracts in English and Rus. } \\
\text { P. 95]. }\end{array}$ \\
\hline Медь в гидробионтах & $\begin{array}{l}\text { Взаимодействие меди с гидробионтами в связи с } \\
\text { экологическим мониторингом и изучением роли } \\
\text { водных организмов в биогеохимических циклах // } \\
\text { Вода: технология и экология. 2007. № 4, с. 54-68. } \\
\text { ISSN 1993-8674 [Совместно: С.А.О., Е.И.Зубкова, } \\
\text { М.В.Крупина, А.А.Микус, И.К.Тодераш]. }\end{array}$ \\
\hline Металлы в раковинах перловиц Unio pictorum & $\begin{array}{l}\text { Изучение содержания металлов в раковинах перловиц } \\
\text { Unio pictorum. - ESHS, 2007, vol. 12, p. 101-102. таб. } \\
\text { Библиогр. } 5 \text { назв. [Совместно: Пуховский А.В., } \\
\text { C.A.O.] }\end{array}$ \\
\hline Металлы в моллюсках Unio pictorum & $\begin{array}{l}\text { Остроумов С.А., Колесов Г.М., Сапожников Д.Ю. } \\
\text { Металлы и вопросы гидробиологического } \\
\text { мониторинга: изучение содержания элементов в } \\
\text { моллюсках Unio рictorum методом нейтронно- } \\
\text { активационного анализа // Проблемы экологии и } \\
\text { гидробиологии / Ред. Тодераш И.К., Остроумов С.А., } \\
\text { Зубкова Е.И. 2008. М.: МАКС Пресс, с. 26-30. Библ. } 3 \\
\text { назв. }\end{array}$ \\
\hline Ртуть в моллюсках & $\begin{array}{l}\text { Остроумов С.А., Хушвахтова С.Д., Данилова В.Н., } \\
\text { Ермаков В.В. Содержание ртути в моллюсках Unio } \\
\text { pictorum, Anodonta, Viviparus viviparous // Проблемы } \\
\text { экологии и гидробиологии / Ред. Тодераш И.К., } \\
\text { Остроумов С.А., Зубкова Е.И. 2008. М.: МАКС Пресс, } \\
\text { с. 31-34. }\end{array}$ \\
\hline Свинец в моллюсках & $\begin{array}{l}\text { Микус А.А., Остроумов С.А., Свинец: опасность, } \\
\text { загрязнение среды, содержание в моллюсках // } \\
\text { Проблемы экологии и гидробиологии / Ред. Тодераш } \\
\text { И.К., Остроумов С.А., Зубкова Е.И. 2008. М.: МАКС } \\
\text { Пресс, с. 35-40. Библ. } 40 \text { назв. }\end{array}$ \\
\hline $\begin{array}{l}\text { Стронций в моллюсках (на примере девяти видов } \\
\text { моллюсков) }\end{array}$ & $\begin{array}{l}\text { Билецки Л.И., Зубков Е.И., Остроумов С.А., } \\
\text { Стронций в моллюсках (на примере девяти видов } \\
\text { моллюсков Кучурганского водоема-охладителя) // } \\
\text { Проблемы экологии и гидробиологии / Ред. Тодераш } \\
\text { И.К., Остроумов С.А., Зубкова Е.И. 2008. М.: МАКС } \\
\text { Пресс, с. 42-43. Библ. } 3 \text { назв. }\end{array}$ \\
\hline $\begin{array}{l}\text { Содержание элементов в пресноводных моллюсках } \\
\text { Unio методом нейтронно-активационного анализа }\end{array}$ & $\begin{array}{l}\text { Остроумов С.А., Колесов Г.М., Сапожников Д.Ю. К } \\
\text { разработке вопросов гидробиологического } \\
\text { мониторинга водной среды: изучение содержания } \\
\text { элементов в моллюсках Uniо методом нейтронно- } \\
\text { активационного анализа // Проблемы экологии и } \\
\text { гидробиологии / Ред. Тодераш И.К., Остроумов С.А., } \\
\text { Зубкова Е.И. 2008. М.: МАКС Пресс, с. 47-53. }\end{array}$ \\
\hline $\begin{array}{l}\text { Содержание металлов } \mathrm{Cd}, \mathrm{Ni}, \mathrm{Cr}, \mathrm{An}, \mathrm{Mn}, \mathrm{Pb} \text { в } \\
\text { раковинах моллюсков Mytilus galloprovincialis) }\end{array}$ & $\begin{array}{l}\text { Клюшников В.Ю., Макаров А.С., Остроумов С.А. } \\
\text { Изучение содержания металлов Cd, Ni, Cr, An, Mn, Pb } \\
\text { в раковинах моллюсков Mytilus galloprovincialis } \\
\text { (Metals in the shells of Mytilus galloprovincialis) // } \\
\text { Проблемы экологии и гидробиологии / Ред. Тодераш } \\
\text { И.К., Остроумов С.А., Зубкова Е.И. 2008. М.: МАКС } \\
\text { Пресс, с. 54-56. Библ. } 4 \text { назв. }\end{array}$ \\
\hline
\end{tabular}




\begin{tabular}{|c|c|}
\hline $\begin{array}{l}\text { Роль макрофитов пресноводных экосистем в } \\
\text { накоплении металлов }\end{array}$ & $\begin{array}{l}\text { Зубкова Е.И., Билецки Л.И., Мунжиу О.В., Остроумов } \\
\text { С.А., Шубернецкий И.В. Роль макрофитов } \\
\text { пресноводных экосистем в накоплении металлов (на } \\
\text { примере Дубоссарского водохранилища) // Проблемы } \\
\text { экологии и гидробиологии / Ред. Тодераш И.К., } \\
\text { Остроумов С.А., Зубкова Е.И. 2008. М.: МАКС Пресс, } \\
\text { с. 63-64. }\end{array}$ \\
\hline Роль моллюсков в биогенной миграции металлов & $\begin{array}{l}\text { Зубкова Е.И., Тодераш И.К., Остроумов С.А., } \\
\text { Билецки Л.И., Мунжиу О.В., Шубернецкий И.В. } \\
\text { Значение моллюсков в биогенной миграции металлов } \\
\text { и влияние металлов на жизнь донных гидробионтов // } \\
\text { Проблемы экологии и гидробиологии / Ред. Тодераш } \\
\text { И.К., Остроумов С.А., Зубкова Е.И. 2008. М.: МАКС } \\
\text { Пресс., с. 64-66. }\end{array}$ \\
\hline $\begin{array}{l}\text { Роль моллюсков в биогенной миграции фосфора: } \\
\text { изучение мягких тканей Dreissena polymorpha }\end{array}$ & $\begin{array}{l}\text { Зубкова Е.И., Тодераш И.К., Мунжиу О.В., } \\
\text { Остроумов С.И., Богинина З.С., Шубернецкий И.В. } \\
\text { Роль моллюсков в биогенной миграции фосфора: } \\
\text { изучение мягких тканей Dreissena polymorphа из } \\
\text { Дубоссарского водохранилища // Проблемы экологии } \\
\text { и гидробиологии / Ред. Тодераш И.К., Остроумов } \\
\text { С.А., Зубкова Е.И. 2008. М.: МАКС Пресс., с. 67-68. }\end{array}$ \\
\hline $\begin{array}{l}\text { Элементы в раковинах моллюсков Viviparus } \\
\text { viviparus: изучение методом нейтронно- } \\
\text { активационного анализа }\end{array}$ & $\begin{array}{l}\text { Остроумов С.А., Колесов Г.М., Сапожников Д.Ю. } \\
\text { Содержание элементов в раковинах моллюсков } \\
\text { моллюсков Viviparus viviparus: изучение методом } \\
\text { нейтронно-активационного анализа // Есоlogical } \\
\text { Studies, Hazards, Solutions. 2009. V. 13, p. 113-117. [= } \\
\text { Ostroumov S.A., Kolesov G.M., Sapozhnikov D.Yu. The } \\
\text { content of chemical elements in the shells of molluscs } \\
\text { Viviparus viviparus: a study by the method of neutron } \\
\text { activation analysis // Ecological Studies, Hazards, } \\
\text { Solutions. 2009. 13: 113-117]. }\end{array}$ \\
\hline $\begin{array}{l}\text { Изучали изменения концентраций тяжелых } \\
\text { металлов в воде экспериментальных систем. } \\
\text { Концентрация тяжелых металлов Сu, Zn, Cd, Рb в } \\
\text { воде экспериментальных микрокосмах змеряли } \\
\text { методом инверсионной вольтамперометрии. В } \\
\text { микрокосмах инкубировали макрофиты } \\
\text { Сеratophyllum demersum. Измеряемые этим } \\
\text { методом концентрации металлов в микрокосмах с } \\
\text { макрофитами снижались значительно быстрее, чем } \\
\text { в контрольных микрокосмах без растений. Новые } \\
\text { результаты дополняют ранее полученные данные о } \\
\text { фиторемедиационном потенциале водных растений } \\
\text { (Becтник Mocк. ун-та. Сер. 16. Биология. - 2007. - } \\
\text { № 4. - C.39-42). Changes in the concentration of } \\
\text { heavy metals in the water of experimental systems } \\
\text { were studied. Using the method of inversion } \\
\text { voltamperometry, the concentrations of the heavy } \\
\text { metals Cu, Zn, Cd, Pb were measured in the water of } \\
\text { the experimental microcosms. Aquatic macrophytes } \\
\text { Ceratophyllum demersum were in the water of the } \\
\text { experimental microcosms. The measured } \\
\text { concentrations of all four heavy metals decreased in }\end{array}$ & $\begin{array}{l}\text { Остроумов С.А., Шестакова Т.В., Котелевцев С.В., } \\
\text { Соломонова Е.А., Головня Е.Г., Поклонов В.А. } \\
\text { Присутствие макрофитов в водной системе ускоряет } \\
\text { снижение концентраций меди, свинца и других } \\
\text { тяжелых металлов в воде. // Водное хозяйство России. } \\
\text { 2009. No. 2. c. } 58 \text { - 67. Табл., Библиогр. } 17 \text { назв. } \\
\text { [=Ostroumov S.A., Shestakova T.V., Kotelevtsev S.V., } \\
\text { Solomonova E.A., Golovnya E.G., Poklonov V.A. } \\
\text { Presence of the macrophytes in aquatic system } \\
\text { accelerated a decrease in concentrations of copper, lead } \\
\text { and other heavy metals in water. // Water Sector of } \\
\text { Russia: Problems, Technologies, Management (=Vodnoe } \\
\text { Khozyaistvo Rossii). 2009. No. 2. p. } 58-67 . \text { Bibliogr. } 17 \\
\text { refs. }\end{array}$ \\
\hline
\end{tabular}


the microcosms with the macrophytes much faster than in the control microcosms without any aquatic plants. The new results complement the previous data on the phytoremediation potential of aquatic plants (Vestnik Moskovskogo Universiteta. Series 16/ Biology. 2007. - № 4. - C.39-42)].

Измерены концентрации элементов в бурых водорослях Cystoseira crinita из Черного моря. Концентрации уменьшались в следующем порядке: $\mathrm{Fe}>\mathrm{Zn}>\mathrm{Mn}>\mathrm{Cr}>\mathrm{As}>\mathrm{Cu}>\mathrm{Pb}>\mathrm{Cd}>\mathrm{Co}$. Данные согласуются с предложенной теорией полифункциональной роли биоты в контроле качества воды и ее самоочищении (ДАН, 2004, T.396. С.136-141; Экология, №. 6, 2005, с. 452459)].

Впервые выявлено нарастание содержания металлов в фитомассе после инкубации в водной среде с наночастицами оксидов металлов.
Immobilization of heavy metal (copper and others) by biomass of macrophytes, after their incubation with nanoparticles $\mathrm{Cu}$ oxides and other metal oxides

Иммобилизация тяжелого металла (на примере меди) биомассой макрофитов

Иммобилизация меди фитомассой макрофитов биогенным материалом
Остроумов С.А., Демина Л.Л. Экологическая биогеохимия и элементы (As, $\mathrm{Co}, \mathrm{Fe}, \mathrm{Mn}, \mathrm{Zn}, \mathrm{Cu}, \mathrm{Cd}$, $\mathrm{Cr}$ ) в цистозире и биогенном детрите в морской модельной экосистеме: определение методом атомноабсорбционной спектрометрии (ААС) // Экологические системы и приборы. 2009. № 9, с.4245.

M.E. Johnson, S.A. Ostorumov, J. F. Tyson, B. Xing, Measuring the concentrations of elements including toxic metals in phytomass after incubation of aquatic macrophytes with nanoparticles of metal oxides // Фундаментальные и инновационные аспекты биогеохимии. Материалы VII биогеохимической школы. 12 - 15 сентября 2011 г. Астрахань-Москва. Москва. 2011, ГЕОХИ. С.66-69.

Ostroumov S.A., Podchernyaeva R. Ya., Suetina I. A., Lopatina O. A., Johnson M.E., Tyson J. F., Xing B. Interactions of nanoparticles of $\mathrm{Cu}$ oxides and other metal ozides with biological objects.

The 2nd International School "Nanomaterials and nanotechnology in living systems. Safety and nanomedicine" (September 19-24, 2011). Moscow. p.142

M.E. Johnson, S.A. Ostorumov, J. F. Tyson, B. Xing. On the biogeochemistry and geochemical ecology of nanotechnology products: interactions of metal oxide nanoparticles with macrophytes and plant-derived materials // Проблемы биогеохимии и геохимической экологии, 2011, № 3 (17). С. 136-148.

Повышение концентрации меди в биомассе макрофитов после инкубации в водной среде, содержащей наночастицы оксида меди.
M.E. Johnson, S.A. Ostorumov, J. F. Tyson, B. Xing, Study of the Interactions between Elodea canadensis and CuO Nanoparticles. 2011, published in Ekologicheskaya Khimiya, 2011, Vol. 20, No. 4, pp. 189-194. In Rus. М. Джонсон, С.А. Остроумов, Дж.Ф.Тайсон, Б. Шин. Изучение взаимодействий Elodea canadensis и наночастиц $\mathrm{CuO} / /$ Экологическая химия, 2011, т. 20, № 4, стр. 189-194

Johnson M. E., S. A. Ostroumov, J. F. Tyson and B. Xing. Study of the interactions between Elodea canadensis and $\mathrm{CuO}$ nanoparticles // Russian Journal of General Chemistry, 2011. Volume 81, Number 13, 26882693, DOI:10.1134/S107036321113010X

[Pleiades Publishing, Ltd. Distributed worldwide by
Cover is one of the key heavy metals that pollute environment. Copper may enter the aquatic environment in both soluble and nanoparticle form. It was previously found in a series of studies that nanoparticles, including those of several metal oxides, exercise both negative and positive effects on the higher plants which makes necessary further research

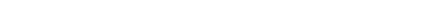




\begin{abstract}
on the interaction between metal oxide nanoparticles and plants. Interaction between aquatic plants and copper-containing nanoparticles were not sufficiently studied. The goal of this study was the investigation of the interactions between $\mathrm{CuO}$ nanoparticles and the aquatic plant Elodea canadensis in experimental microcosms. It was found that $\mathrm{CuO}$ nanoparticles demonstrated some phytotoxicity to Elodea canadensis. After the incubation of Elodea canadensis in the aquatic medium contaminated with $\mathrm{CuO}$ nanoparticles there was a significant increase (by two orders of magnitude) of the concentration of copper in the biomass of the plants. In English.

Иммобилизация тяжелых металлов и других токсичных элементов образцами биомассы биогенного материала
\end{abstract}

[S.A. Ostroumov 1, S.V. Kotelevtsev 1, V.M. Glaser 1, O.M. Gorshkova 1, E.A. Gushina 2, M.E. Johnson 3, V.V. Ermakov 4, A.E. Zhbanov 1, E.I. Zubkova5, L. Jovanovic 6, O.A. Lopatina2, D.N.Matorin1, M.S. Panin7, R. Ya. Podchernyaeva 2, V.A. Poklonov 1, A.P. Sadchikov 1, A.A. Soldatov 8, E.A. Solomonova 1, I.A. Suetina 2, J. F. Tyson 3, I.K. Toderas 5, V.L. Sheleykovsky 9, T. V. Shestakova 1, B. Xing 3. Chemical-biotic interactions in systems with heavy metals and other pollutants: towards innovative ecotechnology].

В различных вариантах эксперимента впервые измерены концентрации редкоземельных элементов в образцах мортмассы нескольких видов макрофитов (в рабте участвовали ученые университета Массачусетса, США).

Выявлена способность биогенного материала (мортмассы макрофитов) иммобилизовывать тяжелые металлы и редкоземельные элементы.

Мортмасcа Myriophyllum aquaticum иммобилизует палладий, скандий, титан, цирконий, уран и другие элементы, находящиеся в водной среде в растворенном виде и в форме наночастиц.
Springer. Russian Journal of General Chemistry ISSN 1070-3632]
С.А. Остроумов, С.В. Котелевцев, В.М. Глазер, О.М. Горшкова, Е.А. Гущина, М.Е. Джонсон, В.В. Ермаков, А.Е. Жбанов, Е.И. Зубкова, Л. Йованович, О.А. Лопатина, Д.Н. Маторин, М.С. Панин, Р.Я. Подчерняева, В.А. Поклонов, А.П. Садчиков, А.А. Солдатов, Е.А. Соломонова, И.А. Суетина, Дж.Ф.Тайсон, И.К. Тодераш, В.Л. Шелейковский, Т.В. Шестакова, Б. Шин. Химико-биотические взаимодействия в системах с тяжелыми металлами и другими поллютантами: к инновационной экотехнологии // Тяжелые металлы и радионуклиды в окружающей среде. Материалы VII Международной научно-практической конференции (Семипалатинск, 4 - 8 октября 2012 года). Т. I. - Семей:

Семипалатинский гос. педагогический ин-т, 2012, с.471-476 (всего в сборнике 519 с.) ISBN 978-6017332-72-3.

С.А.Остроумов. Живое вещество и роль детрита в биогенной миграции микроэлементов (Глава 3). В книге: Инновационные аспекты биогеохимии. 2012. Москва, ГЕОХИ. / Ред. акад. М.А. Федонкин, С.А.Остроумов.
Ostroumov S.A., M.E.Johnson, J.F.Tyson, B.Xing.

Мортмасcа Myriophyllum aquaticum иммобилизует палладий, скандий, титан, цирконий, уран и другие элементы, находящиеся в водной среде в растворенном виде и в форме наночастиц. // Материалы Биогеохимических чтений (2012), Отв. редактор проф. В.В.Ермаков.

Вышеприведенная таблица суммирует лишь часть публикаций по данной теме.

Анализ содержащихся в таблице работ показывает следующее: 1. Получены новые данные о содержании химических элементов в конкретных видах организмов. Среди изученных видов организмов значительное место занимают гидробионты. 
2. В ряде случаев информация о содержании химических элементов дифференцирована с учетом определений, проведенных для различных частей организмов (например, получены новые данные о химическом составе раковин моллюсков.

3. Наряду с определением фоновых концентраций химических элементов измеряли также результаты сорбции и биосорбции химических элементов биогенным материалом в условиях экспериментов. В качестве биогенного материала, для которого измеряли способность к сорбции и биосорбции, использовали не только биомассу, но и мортмассу.

4. Те химические элементы, концентрации которых измеряли, относятся к нескольким группам. Среди них - традиционно изучаемые металлы (в том числе из группы так называемых тяжелых металлов), редкоземельные элементы и некоторые другие. Существенно, что некоторые из этих элементов привлекают к себе внимание как опасные загрязнители биосферы (например, ртуть).

5. Некоторые из изученных элементов имеют значение как факторы эвтрофикации (азот, фосфор), что важно для разработки практических мер по борьбе с эвтрофированием.

Значительная информация содержится также и в других публикациях многих авторов.

Приведем лишь некоторые из них.

Существенный вклад внесли работы ученых РАН - члена-корреспондента РАН Т.И. Моисеенко, Е.И. Коробовой, В.В. Ермакова, члена-корреспондента РАН Э.В. Ивантера, Л.Л .Деминой и многих других ученых. Подробнее о некоторых из этих работ ниже, а также в цитируемой библиографии.

Таблица 2 Результаты в публикациях члена-корреспонента РАН Т.И. Моисеенко и соавт. (некоторые примеры).

\begin{tabular}{|l|l|l|}
\hline год & Комментарии & Публикации \\
\hline 1997 & $\begin{array}{l}\text { Данные о концентрации и накоплении многих } \\
\text { химических элементов в организме пресноводных } \\
\text { гидробионтов }\end{array}$ & $\begin{array}{l}\text { Моисеенко, Т. И., Даувальтер, В. Родюшкин, И. В. (1997). } \\
\text { Геохимическая миграция } \\
\text { элементов в субарктическом } \\
\text { водоеме (на примере озера } \\
\text { Имандра). Апатиты: Изд-во КНЦ } \\
\text { РАН. }\end{array}$ \\
\hline 2016 & $\begin{array}{l}\text { Данные о концентрации и накоплении ртути в } \\
\text { организме рыб многих таксонов }\end{array}$ & $\begin{array}{l}\text { Моисеенко, Т. И., апд Н. А. } \\
\text { Гашкина. "Биоаккумуляция ртути } \\
\text { в рыбах как индикатор уровня } \\
\text { загрязнения вод." Геохимия 6 } \\
\text { (2016): 495-504. }\end{array}$ \\
\hline 2018 & $\begin{array}{l}\text { Данные о концентрации и накоплении кадмия в } \\
\text { организме многих таксонов в связи } \\
\text { токсичностью этого химического элемента и } \\
\text { загрязнением среды }\end{array}$ & $\begin{array}{l}\text { Моисеенко Т. И., Гашкина Н. А. } \\
\text { Биогеохимия кадмия: } \\
\text { антропогенное рассеивание, } \\
\text { биоаккумуляция и } \\
\text { экотоксичность //Геохимия. - } \\
\text { 2018. - №. 8. - С. 759-773. }\end{array}$ \\
\hline
\end{tabular}




\begin{tabular}{|l|l|l|}
\hline 2019 & $\begin{array}{l}\text { Данные о концентрации и накоплении металлов в } \\
\text { организме многих таксонов в связи } \\
\text { токсичностью этих химического элемента, } \\
\text { загрязнением среды, и вопросами } \\
\text { биодоступности металлов }\end{array}$ & Биодоступность и экотоксичность \\
& металлов в водных системах: \\
& критические уровни загрязнения. \\
Геохимия, 64(7), 675-688.
\end{tabular}

Существенный объем новых данных получен и проанализирован в книгах и статьях д.б.н. В.В.Ермакова (Институт геохимии и аналитической химии РАН). Примеры - ниже в Таблице 3.

Таблица 3 Результаты в публикациях В.В.Ермакова и соавт. (некоторые примеры)

\begin{tabular}{|c|c|c|}
\hline Химические элементы & Комментарии & Публикации \\
\hline Селен & $\begin{array}{l}\text { Получены данные о концентрации } \\
\text { и накоплении селена в организмах } \\
\text { многих таксонов, показана } \\
\text { большая роль селена в } \\
\text { метаболизме }\end{array}$ & $\begin{array}{l}\text { Ермаков, В. В., \& Ковальский, В. } \\
\text { В. (1974). Биологическое значение } \\
\text { селена. }\end{array}$ \\
\hline Многие химические элементы & $\begin{array}{l}\text { Получены и систематизированы } \\
\text { данные о концентрации и } \\
\text { накоплении металлов и других } \\
\text { химических элементов в животных } \\
\text { многих таксонов }\end{array}$ & $\begin{array}{l}\text { Ермаков, В. В., \& Тютиков, С. Ф. } \\
\text { (2008). Геохимическая экология } \\
\text { животных. } \\
\text { М.,Наука/Интерпериодика". }\end{array}$ \\
\hline Многие химические элементы & $\begin{array}{l}\text { систематизированы данные о } \\
\text { концентрации и накоплении } \\
\text { металлов и других химических } \\
\text { элементов в организмах многих } \\
\text { таксонов, во многих объектах } \\
\text { геохимической среды ( в том } \\
\text { числе в почвах и океане) }\end{array}$ & $\begin{array}{l}\text { Ермаков, В. В., Карпова, Е. А., } \\
\text { Корж, В. Д., \& Остроумов, С. А. } \\
\text { (2012). Инновационные аспекты } \\
\text { биогеохимии. }\end{array}$ \\
\hline $\begin{array}{l}\text { металлы и другие химические } \\
\text { элементы }\end{array}$ & $\begin{array}{l}\text { в организмах многих таксонов, во } \\
\text { многих объектах геохимической } \\
\text { среды }\end{array}$ & $\begin{array}{l}\text { Ермаков, В. В. (2015). } \\
\text { Геохимическая экология и } \\
\text { биогеохимические критерии } \\
\text { оценки экологического состояния } \\
\text { таксонов биосферы. Геохимия, (3), } \\
203-221 .\end{array}$ \\
\hline металлы & $\begin{array}{l}\text { Получены и систематизированы } \\
\text { данные о концентрации и } \\
\text { накоплении металлов в элодее } \\
\text { канадской }\end{array}$ & $\begin{array}{l}\text { Остроумов, С. А., Данилова, В. Н., } \\
\text { Хушвахтова, С. Д., Ермаков, В. В., } \\
\text { Тютиков, С. Ф., Тропин, И. В., \& } \\
\text { Котелевцев, С. В. (2016). } \\
\text { Содержание химических } \\
\text { элементов, глутатиона и }\end{array}$ \\
\hline
\end{tabular}




\begin{tabular}{|c|c|c|}
\hline & & $\begin{array}{l}\text { металлотионеинов в элодее } \\
\text { канадской (Elodea canadensis) в } \\
\text { связи с экологическим } \\
\text { мониторингом. Экологическая } \\
\text { химия, 25(4), 197-203. }\end{array}$ \\
\hline Ртуть & $\begin{array}{l}\text { Систематизированы данные о } \\
\text { концентрации и накоплении ртути } \\
\text { в организмах многих таксонов, во } \\
\text { многих объектах геохимической } \\
\text { среды }\end{array}$ & $\begin{array}{l}\text { Данилова, В. Н., Хушвахтова, С. } \\
\text { Д., Ермаков, В. В., \& Остроумов, } \\
\text { С. А. (2018). Биогеохимические } \\
\text { аспекты аккумулирования ртути в } \\
\text { биосфере. In Труды } \\
\text { Всероссийского ежегодного } \\
\text { семинара по экспериментальной } \\
\text { минералогии, петрологии и } \\
\text { геохимии (рр. 394-396). }\end{array}$ \\
\hline
\end{tabular}

Дополнительно к изложенному выше, приедем еще примеры работ по определению концентрации химических элементов в биомассе организмов - на примере растений. См. таблицу 4 ниже.

Таблица 4 . Результаты измерения содержания некоторых из изученных в данной работе элементов в образцах растительного материала (данные различных авторов).

\begin{tabular}{|c|c|c|c|}
\hline Элементы & $\begin{array}{l}\text { Образцы } \\
\text { материала } \\
\text { растений }\end{array}$ & $\begin{array}{l}\text { Концентрации } \\
\text { На сухой вес }\end{array}$ & Ссылки \\
\hline $\begin{array}{l}\text { Палладий } \\
\text { Pd }\end{array}$ & Pinus radiate & $\begin{array}{l}15 \pm 15 \text { ррь в золе. } \\
\text { Зола составляла } 3 \% \text { от } \\
\text { сухого веса образцов. }\end{array}$ & $\begin{array}{l}\text { Kothny E.L. Palladium in plant ash. // Plant and Soil. } \\
\text { 1979. Vol.53. P.547-550. }\end{array}$ \\
\hline $\begin{array}{l}\text { Скандий } \\
\text { Sc }\end{array}$ & $\begin{array}{l}\text { Различные } \\
\text { виды }\end{array}$ & $\begin{array}{l}\text { Из многих } \\
\text { исследованных } \\
\text { образцов различных } \\
\text { видов растений лишь } \\
\text { в 3\% содержание } \\
\text { было выше предела } \\
\text { обнаружения. } \\
\text { Обнаруженные } \\
\text { концентрации были на } \\
\text { уровне нескольких } \\
\text { мкг/ кг (ррь). }\end{array}$ & $\begin{array}{l}\text { Scandium. Chemical properties of scandium. Health } \\
\text { effects of scandium. Environmental effects of scandium. } \\
\text { http://www.lenntech.com/periodic/elements/sc.htm ; }\end{array}$ \\
\hline Титан Тi & $\begin{array}{l}\text { Diandrostachi } \\
\text { a chrysotrix, } \\
\text { Erythroxylum } \\
\text { sp., Leandra } \\
\text { aurea }\end{array}$ & $3-9,5 \mathrm{mg} / \mathrm{kg}$ & $\begin{array}{l}\text { Ceccantini G., Figueiredo A.M.G., Sondag F., Soubies F. } \\
\text { Rare earth elements and titanium in plants. soils and } \\
\text { groundwaters in the alkaline-ultramafic complex of } \\
\text { Salitre, MG, Brazil // Contaminated Soils. 3rd } \\
\text { international Conference on the Biogeochemistry of } \\
\text { Trace Elements. Paris (France). May 15-19, 1995; } \\
\text { http://horizon.documentation.ird.fr/exl- } \\
\text { doc/pleins_textes/pleins_textes_7/b_fdi_51- } \\
\text { 52/010015618.pdf }\end{array}$ \\
\hline
\end{tabular}




\begin{tabular}{|c|c|c|c|}
\hline $\begin{array}{l}\text { Цирконий } \\
\mathrm{Zr}\end{array}$ & $\begin{array}{l}\text { Томаты, } \\
\text { корни } \\
\text { Lycopersicon } \\
\text { esculentum L. }\end{array}$ & $\begin{array}{l}\text { 2,60-7,96 мг/кг } \\
\text { (выращивали на } \\
\text { почве); 2,84 мг/кг } \\
\text { (гидропоника) }\end{array}$ & $\begin{array}{l}\text { Ferrand E., Benedetti M. F., Leclerc-Cessac E., and } \\
\text { Dumat C. Study of the mechanisms involved in the } \\
\text { rhizosphere for the absorption of zirconium by vegetables } \\
\text { // Difpolmine Conference. 12-14 December 2006. Le } \\
\text { Corum - Montpellier, France. } \\
\text { http://www.ademe.r/difpolmine/Difpolmine_RapportFina } \\
\text { 1/communication/12_13_posters- } \\
\text { Corum/Difpolmine_Poster13_Dumat_proceeding.pdf }\end{array}$ \\
\hline $\mathrm{Zr}$ & $\begin{array}{l}\text { Горох, корни } \\
\text { Pisum sativum }\end{array}$ & $\begin{array}{l}\text { 1,08-1,15 (на почве); } \\
\text { 0,58 (гидропоника) }\end{array}$ & $\begin{array}{l}\text { Ferrand E., Benedetti M. F., Leclerc-Cessac E., and } \\
\text { Dumat C. Study of the mechanisms involved in the } \\
\text { rhizosphere for the absorption of zirconium by vegetables } \\
\text { // Difpolmine Conference. 12-14 December 2006. Le } \\
\text { Corum - Montpellier, France. } \\
\text { http://www.ademe.r/difpolmine/Difpolmine_RapportFina } \\
\text { 1/communication/12_13_posters- } \\
\text { Corum/Difpolmine_Poster13_Dumat_proceeding.pdf }\end{array}$ \\
\hline $\begin{array}{l}\text { Палладий, } \\
\text { скандий, } \\
\text { цирконий, } \\
\text { титан }\end{array}$ & $\begin{array}{l}\text { Myriophyllum } \\
\text { aquaticum }\end{array}$ & $\begin{array}{l}\text { Содержание } \\
\text { элементов в } \\
\text { мортмассе } \\
\text { Myriophyllum } \\
\text { aquaticum - см. текст } \\
\text { публикации (ссылка } \\
\text { справа) }\end{array}$ & $\begin{array}{l}\text { Остроумов С. А. Химико-биологические } \\
\text { взаимодействия и новое в учении о биосфере В.И. } \\
\text { Вернадского. Москва, МАКС-Пресс. } 2013.92 \text { с. }\end{array}$ \\
\hline
\end{tabular}

Заключение: Актуальность вопроса о судьбе изученных элементов в окружающей среде (в том числе вопрос о накоплении их в организмах) связана с их практическим использованием в промышленности и производстве различных изделий и материалов, что неизбежно создает новые виды загрязнения окружающей среды, в том числе водных объектов.

Новые данные, упомянутые выше, открывают путь к более глубокому познанию биогеохимических потоков химических элементов в окружающей среде, к дополнительному пониманию того, что В.И.Вернадский назвал биогенной миграцией атомов химических элементов.

Полученная новая информация о накоплении химических элементов в организмах будет способствовать: (1) более глубокому пониманию фундаментальных проблем геохимии и биогеохимии, химической и биохимической экологии; (2) поиску путей решения проблем химического загрязнения биосферы.

\section{ЛИТЕРАТУРА}

1. Абакумов В.А. Инновационные подходы к восстановлению и ремедиации загрязненных водных объектов // Вода: технология и экология. 2007. № 4. С.69-73.

2. Абакумов В.А. Новое о ремедиации и восстановлении загрязненных водных систем // Проблемы биогеохимии и геохимической экологии. 2007, № 2 (4), с. 98-100.

3. Алимов А.Ф. Функциональная экология пресноводных двустворчатых моллюсков. Л.: Наука, 1981. 248 с.; Элементы теории функционирования водных экосистем. СанктПетербург: Наука. 2000. 147 с. 
4. Биологический контроль окружающей среды: биоиндикация и биотестирование» / Ред. О.П. Мелехова, Е.И. Сарапульцева. М.: Издательский центр «Академия» 2008, 288 с. ISBN 978-5-7695-5594-7. 2-е изд., испр.

5. Брагинский Л.П., Л.А. Сиренко. Всесторонний анализ токсикологической опасности поверхностно - активных веществ для гидробионтов. - Гидробиологический журнал. 2003, т. 39, № 3, с. 115 -118.

6. Брагинский Л.П., К.П. Калениченко, А.А. Игнатюк. Обобщенные механизмы самоочищения природных вод. // Гидробиологическ журнал. - 2007. - т.43, № 6. - С. 111- 113.

7. Вернадский В.И. Биосфера. М.: Издательский дом "Ноосфера", 2001. - 243 с.

8. Вернадский В. И. Химическое строение биосферы Земли и её окружения. Москва. Наука, 1965. 374 с.

9. Вернадский В.И., Биосфера и ноосфера. М.: Наука.1989, 261 с.

10. Галимов Э.М. Природа биологического фракционирования изотопов. М. Наука. 1981. $247 \mathrm{c}$.

11. Гордеев В.В. Лисицын А.П. Микроэлементы. В кн.: Химия океана.т.1. М.: Наука, 1979. C.337-375.

12. Демина Л.Л. Формы миграции тяжелых металлов в океане. М.: Наука.1982. 120 с.

13. Добровольский Г.В. О развитии некоторых концепций учения о биосфере // Вода: технология и экология. 2007. № 1. С. 63-68.

14. Добровольский Г.В. К 80-летию выхода в свет книги В.И. Вернадского "Биосфера". Развитие некоторых важных разделов учения о биосфере // Экологическая химия. 2007. т.16(3). С.135-143.

15. Добровольский Г.В., Г.С. Розенберг, И.К. Тодераш. (ред). Открытие нового вида опасных антропогенных воздействий в экологии животных и биосфере: ингибирование фильтрационной активности моллюсков поверхностно-активными веществами. Москва: МАКС-Пресс, 2008, 108 с., ISBN 978-5-317-02370-6.

16. Донченко В.К., Иванова В.В., Питулько В.М. Эколого-химические особенности прибрежных акваторий. Спб. НИЦЭБ РАН. 2008. 544 с.

17. Ермаков B.В. Техногенез и биогеохимическая эволюция таксонов биосферы (Technogenesis and biogeochemical evolution of the biospheric taxons).- М: Наука. - 2003. $351 \mathrm{c}$.

18. Ермаков В.В. Изучение взаимодействия загрязняющих веществ с водными организмами // Вода: технология и экология. 2009. №2. стр. $69-73$.

19. Ермаков В.В., Тютиков С.Ф. Химический состав живого вещества. // Проблемы биогеохимии и геохимической экологии. 2008. № 3 (7). С.3-16.

20. Ермаков В.В., Тютиков С.Ф. Геохимическая экология животных. М.: Наука. 2008. 315 c.

21. Жиров В.К. Поиск фитотехнологий для очищения воды // Проблемы биогеохимии и геохимической экологии, 2008, №3 (7), с.155-156.

22. Жиров В.К. О новых исследованиях взаимодействия загрязняющих веществ с макрофитами в связи с изучением их фиторемедиационного потенциала // Вода: технология и экология. 2009. № 1. стр. 72-74.

23. Ивантер Э.В., Медведев Н.В. Экологическая токсикология природных популяций. М.: Наука. 2007. 229 с. 
24. Корж В.Д. Геохимия элементного состава гидросферы. М. Наука. 1991. 244 с.

25. Котелевцев С. В., Стволинский С.Л., Бейм А.М. Эколого-токсикологический анализ на основе биологических мембран. - М.: МГУ, 1986. -105 с.

26. Криксунов Е.А. Новое в изучении современных проблем экологии, гидробиологии и наук об окружающей среде. - Экология окружающей среды и безопасность жизнедеятельности. 2006, № 6. стр. 93.

27. Митропольский А.Ю. Environment Ecology and Safety of Life Activity (='Ecology of surroundings and safety of vital activity', “Экология окружающей среды и безопасность жизнедеятельности”). 2007. №5. с.81-85. ISSN 1726-5428.

28. Остроумов С.А. Всемирная стратегия охраны природы // Природа. 1980. № 12. С.40-41.

29. Остроумов С.А. Загрязнение воздуха изменяет проницаемость мембран растительных клеток // Природа. 1980. № 3, с. 115.

30. Остроумов С.А. Химия экологических связей между организмами. Рец. на книгу: М. Барбье "Введение в химическую экологию" М.: Мир. 1978 // Бюллетень МОИП. Отд. биол. 1980. т.85. вып. 4. С.123-125.

31. Остроумов С.А. Введение в биохимическую экологию. 1986. М.: Изд-во Московского университета. $176 \mathrm{c.}$

32. Остроумов С.А. Биологические эффекты поверхностно-активных веществ в связи с антропогенными воздействиями на биосферу. М.: МАКС-Пресс. 2000. 116 с. ISBN 5317-00040-8. Предисловие академика М.Е. Виноградова.

33. Остроумов С.А. Биологические эффекты при воздействии поверхностно-активных веществ на организмы. М.: МАКС-Пресс. 2001. Х. 334 с. ISBN 5-317-00323-7. Предисловие академика М.Е. Виноградова.

34. Остроумов С.А. Сохранение биоразнообразия и качество воды: роль обратных связей в экосистемах. // Доклады Академии наук. 2002. Т. 383. № 1. С. 138.

35. Остроумов С.А. Биологический механизм самоочищения в природных водоемах и водотоках: теория и приложения // Успехи современной биологии. 2004. Т. 124. № 5. С. 429.

36. Остроумов С.А. О биотическом самоочищении водных экосистем. Элементы теории // Доклады Академии наук. 2004. Т. 396. № 1. С. 136.

37. Остроумов С.А. О некоторых вопросах поддержания качества воды и ее самоочищения // Водные ресурсы. 2005. Т. 32. № 3. С. 337-346.

38. Остроумов С.А. Ингибиторный анализ регуляторных взаимодействий в трофических цепях // Доклады Академии наук. 2000. Т. 375. № 6. С. 847.

39. Остроумов С.А. Синэкологические основы решения проблемы эвтрофирования// Доклады Академии наук. 2001. Т. 381. № 5. С. 709.

40. Остроумов С.А. О полифункциональной роли биоты в самоочищении водных экосистем // Экология. 2005. № 6. С. 452-459. Остроумов С.А. Биотический механизм самоочищения пресных и морских вод. Элементы теории и приложения = Biotic mechanism of self-purification of freshwater and marine water.М.: МАКС Пресc. 2004. 96 c. ISBN 5-317-01120-5.

41. Остроумов С.А. Загрязнение, самоочищение и восстановление водных экосистем = Pollution, self-purification and restoration of aquatic ecosystems. М.: МАКС Пресc. 2005. 100 c. ISBN 5-317-01213-9. 
42. Остроумов С.А. Геохимический аппарат водных экосистем: биокосная регуляция // Вестник РАН. 2004. Т.74. № 9. С.785-791.

43. Остроумов С.А. Гидробиологическое самоочищение вод: от изучения биологических механизмов к поиску экотехнологий (Серия «Академические чтения», вып. 48) - М.: ФГУП Изд-во «Нефть и газ» РГУ нефти и газа им. И.М. Губкина, 2007. - 52 с.

44. Остроумов С.А. Биологические фильтраторы - важная часть биосферы // Наука в России. 2009. № 2. с. 30-36.

45. Остроумов С.А. Гидробионты в самоочищении вод и биогенной миграции элементов. М. МАКС-Пресс. 2008. 200 с. Предисловие акад. РАН В.В.Малахова. ISBN 978-5-31702625-7.

46. Перельман А.И., Касимов Н.С. 2000. Геохимия ландшафта: - М.: Астрея-2000. - 763 с.

47. Проблемы экологии и гидробиологии / Ред. И.К. Тодераш, С.А. Остроумов, Е.И. Зубкова. Москва, МАКС пресс. 2008. - 80 с. ISBN 978-5-317-02224-2.

48. Розенберг Г.С. «Экология в картинах (учебное пособие)». Тольятти: ИЭВБ РАН, 2007, c.146. ISBN 978-5-93424-298-6.

49. Розенберг Г.С., Мозговой Д.П., Гелашвили Д.Б. Экология: элементы теоретических конструкций современной экологии. Самара: Самарский научн. центр РАН.1999. 396 с.

50. Романенко В.Д., Романенко А.В. На стыке наук. - Гидробиол. журнал. 1992. -Т. 28. № 2. - С. 82 - 83.

51. Скулачев В.П. Энергетика биологических мембран. 1989, 564 с.

52. Телитченко М.М., Остроумов С.А. Введение в проблемы биохимической экологии. М.: Наука. 1990. 288 с. ISBN 5-02-004062-2 (= Introduction to Problems of Biochemical Ecology: Biotechnology, Agriculture, Environment).

53. Федонкин М.А.. Об исследованиях связи вопросов самоочищения воды и биогенной миграции элементов в биосфере // Экологическая химия 2009, 18(1): 60-61.

54. Чернова О. В., Н. О. Ковалева. О работе научного семинара по теоретическим проблемам почвоведения в 2004-2006 гг. - Почвоведение. 2007. № 10. С. 1275-1280.

55. Шредингер Э. (SchrödingerЕ.) Что такое жизнь с точки зрения физики. М.: ИЛ, 1947.

56. Яблоков А.В., Остроумов С.А. Охрана живой природы: проблемы и перспективы. 1983. М.: Леспромиздат. 272 с.

57. Яблоков А.В., Остроумов С.А. Уровни охраны живой природы. М.: Наука, 1985. 176 с.

58. Goldsmith F. B. - The Journal of Ecology, 1992. Vol. 80, No. 1, p. 186-187;

59. Hartshorn G. S. A Russian "Silent Spring". - BioScience, 1992, Vol. 42, No. 7, p. 559-560.

60. Kapitsa A.P. Formulation of fundamental principles for foundation of the theory of the apparatus of the biosphere. - Environment Ecology and Safety of Life Activity (Kiev). 2007. No. 1 (37). P. 68-71.

61. Kapitsa P.L. Review of the book: S.A. Ostroumov. Aquatic organisms in water selfpurification and biogenic migration of elements. Moscow. MAX Press. 2008. 200 p. Ecologica, 2009. V.16. No. 53.P.8.

62. Kolesov G.M. Determination of microelements: neutron activation analysis in geochemistry and cosmochemistry // J. Anal. Chem. 1994. V.49. No.1. P.50-58.

63. McCutcheon S.C., Schnoor J.L. (Eds) Phytoremediation. Wiley. Hoboken. 2003. 988 p.

64. Ostroumov S.A. Inhibitory analysis of top-down control: new keys to studying eutrophication, algal blooms, and water self-purification. - Hydrobiologia. 2002. T. 469. № 13. C. 117-129. 
65. Ostroumov S.A. Some aspects of water filtering activity of filter-feeders. -Hydrobiologia. (2005) v.542. p. 275-286.

66. Ostroumov S.A. Biological Effects of Surfactants.CRC Press.Taylor \& Francis.Boca Raton, London, New York. 2006. 279 p. Subject Index: p.255-279. ISBN 0-8493-2526-9.

67. Ostroumov S.A., Dodson S., Hamilton D., Peterson S., Wetzel R.G. Medium-term and longterm priorities in ecological studies // Rivista di Biologia / Biology Forum. 2003. 96: 327-332. Abstracts in Eng. and Italian (p. 332). Bibliogr. 20 ref.

68. Yablokov A.V., Ostroumov S.A.Conservacion de la Naturaleza Viva. 1989. Moscu (Moscow).Vneshtorgizdat Press. Editorial Científico-Técnica.238 р. (на испанск. яз.).

69. Yablokov A.V., Ostroumov S.A.Conservation of Living Nature and Resources: Problems, Trends, and Prospects. Berlin, New York et al. Springer. 1991. 272 p. ISBN 3-540-52096-1; ISBN 0-387-52096-1.

70. Моисеенко, Т. И., Даувальтер, В. А., \& Родюшкин, И. В. (1997). Геохимическая миграция элементов в субарктическом водоеме (на примере озера Имандра). Апатиты: Изд-во КНЦ РАН.

71. Моисеенко, Т. И., Н. А. Гашкина. "Биоаккумуляция ртути в рыбах как индикатор уровня загрязнения вод." Геохимия 6 (2016): 495-504.

72. Моисеенко Т. И., Гашкина Н. А. Биогеохимия кадмия: антропогенное рассеивание, биоаккумуляция и экотоксичность //Геохимия. - 2018. - №. 8. - С. 759-773.

73. Моисеенко, Т. И. (2019). Биодоступность и экотоксичность металлов в водных системах: критические уровни загрязнения. Геохимия, 64(7), 675-688.

74. Ермаков, В. В., \& Ковальский, В. В. (1974). Биологическое значение селена. Москва : Наука, 1974. - 298 с.

75. Ермаков, В. В., Тютиков, С. Ф., Дегтярев, А. П., Данилова, В. Н., Гуляева, У. А., \& Догадкин, Д. Н. (2020). Формирование биогеохимических аномалий в бассейне р. Баксан. Геохимия, 65(10), 955-968.

76. Ермаков, В. В., Карпова, Е. А., Корж, В. Д., \& Остроумов, С. А. (2012). Инновационные аспекты биогеохимии. (Под ред.: Федонкин М.А., Остроумов С.А.); Москва, ГЕОХИ PAH, 2012. 345 c. https://www.researchgate.net/publication/269093017;

77. Ермаков, В. В. (2015). Геохимическая экология и биогеохимические критерии оценки экологического состояния таксонов биосферы. Геохимия, (3), 203-221.

78. Остроумов, С. А., Данилова, В. Н., Хушвахтова, С. Д., Ермаков, В. В., Тютиков, С. Ф., Тропин, И. В., \& Котелевцев, С. В. (2016). Содержание химических элементов, глутатиона и металлотионеинов в элодее канадской (Elodea canadensis) в связи с экологическим мониторингом. Экологическая химия, 25(4), 197-203.

79. Данилова, В. Н., Хушвахтова, С. Д., Ермаков, В. В., \& Остроумов, С. А. (2018). Биогеохимические аспекты аккумулирования ртути в биосфере. In Труды Всероссийского ежегодного семинара по экспериментальной минералогии, петрологии и геохимии (рр. 394-396).

80. Остроумов С. А. Химико-биологические взаимодействия и новое в учении о биосфере В.И. Вернадского. Москва, МАКС-Пресс. 2013. 92 с.

81. Kothny E.L. Palladium in plant ash. // Plant and Soil. 1979. Vol.53. P.547-550.

82. Scandium. Chemical properties of scandium. Health effects of scandium. Environmental effects of scandium. http://www.lenntech.com/periodic/elements/sc.htm ; 
83. Ceccantini G., Figueiredo A.M.G., Sondag F., Soubies F. Rare earth elements and titanium in plants. soils and groundwaters in the alkaline-ultramafic complex of Salitre, MG, Brazil // Contaminated Soils. 3rd international Conference on the Biogeochemistry of Trace Elements. Paris (France). May 15-19, 1995; http://horizon.documentation.ird.fr/exldoc/pleins_textes/pleins_textes_7/b_fdi_51-52/010015618.pdf

84. Ferrand E., Benedetti M. F., Leclerc-Cessac E., and Dumat C. Study of the mechanisms involved in the rhizosphere for the absorption of zirconium by vegetables // Difpolmine Conference. 12-14 December 2006. Le Corum - Montpellier, France. http://www.ademe.r/difpolmine/Difpolmine_RapportFinal/communication/12_13_postersCorum/Difpolmine_Poster13_Dumat_proceeding.pdf;

85. Ferrand E., Benedetti M. F., Leclerc-Cessac E., and Dumat C. Study of the mechanisms involved in the rhizosphere for the absorption of zirconium by vegetables // Difpolmine Conference. 12-14 December 2006. Le Corum - Montpellier, France. http://www.ademe.r/difpolmine/Difpolmine_RapportFinal/communication/12_13_postersCorum/Difpolmine_Poster13_Dumat_proceeding.pdf ;

86. Остроумов С.А., Тодераш И.К., Зубкова Е.И., Котелевцев С.В., Ермаков В.В., Крупина М.В., Ене А., Микус А.А., Билецки Л.И., Бряхнэ А., Мирон А. Биогенная миграция меди в водных экосистемах // Известия Академии наук Молдовы. Науки о жизни [ Buletinul Academiei de stiinte a Moldovei. Life Sciences], № 3, c. 4-21.

87. Остроумов С.А., Колесов Г.М., Тодераш И.К., Ени А. Выявление элементов (La, Au, $\mathrm{U}, \mathrm{Cs}, \mathrm{Ba}, \mathrm{Na}, \mathrm{Ce}, \mathrm{Se}, \mathrm{Sb}, \mathrm{Hf}, \mathrm{Th}, \mathrm{Sc}, \mathrm{Sm}$ и других) в биогенном детрите водных микрокосмов с Viviparus viviparus, Unio pictorum, Ceratophyllum demersum // Известия Академии наук Молдовы. Науки о жизни [ Buletinul Academiei de stiinte a Moldovei. Life Sciences], 2009. № 2 (308), c. 85-95.

88. Остроумов С.А., Колесов Г.М. Детектирование в компонентах экосистем золота, урана и других элементов методом нейтронно-активационного анализа // Экологические системы и приборы, [издательство Научтехлитиздат (М.)], 2009. № 10, с. 37-40.

89. Korobova E. M. Toxicity as a Biogeochemical Problem //Geochemistry International. - 2020. - T. 58. - №. 10. - C. 1092-1096.

90. Korobova, E. M. (2017). Combined assessment of the ecological and geochemical state of anthropogenically impacted areas. Geochemistry International, 55(10), 861-871.

91. Korobova, E. M. (2017). Principles of spatial organization and evolution of the biosphere and the noosphere. Geochemistry International, 55(13), 1205-1282.

92. Korobova, E. M., Berezkin, V. U., Korsakova, N. V., Krigman, L. V., Romanov, S. L., \& Baranchukov, V. S. (2019). Iodine in Soils and Potatoes Produced in Private Farms of Bryansk and Gomel Regions Located in the Impact Zone of the Chernobyl Accident. Eurasian Soil Science, 52(10), 1266-1273.

93. Korobova, E., Romanov, S., \& Silenok, A. (2020). Endemic diseases of geochemical origin and methodological approaches toward their prevention and elimination. Environmental geochemistry and health, 42(8), 2595-2608.

94. Korobova, E. M., Beryozkin, V. U., Kolmykova, L. I., Korsakova, N. V., \& Krigman, L. V. (2016). Iodine deficiency in agricultural landscapes of the Bryansk region. RUDN Journal of Ecology and Life Safety, (3), 57-65.

95. Ермаков В. В., Моисеенко Т. И. Х Международная биогеохимическая школа //Вестник Тюменского государственного университета. Вестник Тюменского государственного 
университета. Экология и природопользование. 2017. Том 3. No. 2. С. 166-175. https://elib.utmn.ru/jspui/bitstream/ru-tsu/15256/1/166_175.pdf;

96. Ermakov, V., Bech, J., Gulyaeva, U., Tyutikov, S., Safonov, V., Danilova, V., \& Roca, N. (2020). Relationship of the mobile forms of calcium and strontium in soils with their accumulation in meadow plants in the area of Kashin-Beck endemia. Environmental Geochemistry and Health, 42(1), 159-171.

97. Ermakov, V. V., Gulyaeva, U. A., Tyutikov, S. F., Kuz'mina, T. G., \& Safonov, V. A. (2017). Biogeochemistry of calcium and strontium in the landscapes of eastern Transbaikalia. Geochemistry International, 55(12), 1105-1117.

98. Ermakov, V. V., Tyutikov, S. F., \& Danilova, V. N. (2020). Ecological Monitoring of the Unal Depression, Northern Ossetiya-Alania, Using Techniques of Biogeochemical Indication. Geochemistry International, 58(3), 332-341.

99. Ermakov, V. V., Tyutikov, S. F., Degtyarev, A. P., Safonov, V. A., Danilova, V. N., Khushvakhtova, S. D., ... \& Krechetova, E. V. (2018). Biogeochemical differentiation of living matter and biodiversity in the Ardon polymetallic subregion of the biosphere. Geochemistry International, 56(4), 318-331.

100. Ermakov, V. V., Tyutikov, S. F., Degtyarev, A. P., Danilova, V. N., Gulyaeva, U. A., \& Dogadkin, D. N. (2020). Formation of Biogeochemical Anomalies in the Baksan River Basin. Geochemistry International, 58(10), 1097-1109. 


\title{
РЕЗУЛЬТАТЫ ТЕРАПИИ ПАЦИЕНТОВ С ДИАГНОЗОМ «НЕЙРОБЛАСТОМА» СОГЛАСНО ПРОТОКОЛУ NВ-2004
}

\author{
${ }^{1}$ Мария Галас, ${ }^{2}$ Алия Жайлаубаева, ${ }^{3}$ Бахрам Жумадуллаев, ${ }^{4}$ Айгуль Баязитовна, ${ }^{5}$ Ляззат \\ Манжуова, ${ }^{6}$ Риза Боранбаева
}

${ }^{1}$ врач детский онколог-гематолог, Научный центр педиатрии и детской хирургии, Алматы, Республика Казахстан, ${ }^{2}$ врач детский онколог-гематолог первой категории, заведующая отделением онкологии и гематологии №4, Научный центр педиатрии и детской хирургии, Казахстан,

${ }^{3}$ Кмн., врач детский онколог-гематолог высшей категории, заведующий отделением хирургии №2, Научный центр педиатрии и детской хирургии, Алматы, Республика Казахстан, Тулебаева ${ }^{4}$ кмн., врач детский онколог-гематолог высшей категории, заведующая отделением ТГСК, Научный центр педиатрии и детской хирургии, Казахстан,

${ }^{5}$ Кмн., врач детский онколог-гематолог высшей категории, заместитель председателя Правления по научноклинической и инновационной деятельности, Казахстан,

6Дмн., Председатель Правления АО «Научный центр педиатрии и детской хирургии», Главный детский онкогематолог Министерства здравоохранения Республики Казахстан, Казахстан.

\section{РЕЗЮМЕ}

Нейробластома (НБ) - самая распространенная экстракраниальная солидная опухоль детского возраста, развивающаяся из клеток-предшественников симпатической нервной системы

Цель: Оценить результаты лечения пациентов с диагнозом «нейробластома» согласно протоколу NB-2004 в Научном центре педиатрии и детской хирургии (НЦПиДХ)

Материалы и методы: Проанализированы 113 случаев НБ, установленных в НЦПДХ с 2015 по ноябрь 2020 года: 57 мальчиков и 56 девочек. Медиана возраста на момент постановки диагноза 21,5 месяцев (0,8-191,8). Локализация опухоли: забрюшинно у 93 пациентов, в средостении - у 12; и в средостении, и забрюшинно - у 3, в области шеи - у 3 , без первичного очага - у 2. В 22,1\% случаев выявлена амплификация гена N-MYC, 1 p - 5,3\%. Стратификации на группы риска: «observation group» - 26 пациентов $(23 \%)$, группа промежуточного риска (ГПВ) - 14 (12,4\%), группа высокого риска - 73 больных (64,6\%).

Анализ общей выживаемости (ОВ) и бессобытийной выживаемости (БСВ) выполнен методом Каплан-Майера в программе IBM SPSS Statistics.

Результаты: Медиана наблюдения составила - 20,4 месяца (0,03-132,43). Пятилетняя ОВ составила - 61,9\%. 2-летняя БСВ - 35\%. Прогрессия НБ отмечалась в 24 случаях $(21,2 \%)$, рецидив НБ - у 18 пациентов (15,9\%).

ОВ в группе высокого риска - 43,8\%, в ГПВ - 85,7\%, в группе низкого риска - 100\%. 37 пациентам из группы высокого риска проведена ауто-ТГСК. ОВ в группе после ауто-ТГСК 54,1\%. Медиана наблюдения после ауто-ТГСК - 12,47 месяцев (0,13 месяцев до 61,03 месяца).

Выводы: Терапия согласно протоколу NB-2004 является эффективной и показывает высокую ОВ в низкой и промежуточной группе риска. ОВ в высокой группе риска - 43\%, что требует оптимизации диагностики, разработки новых подходов терапии пациентов данной группы. Ключевые слова: нейробластома, общая выживаемость, злокачественное новообразование. 


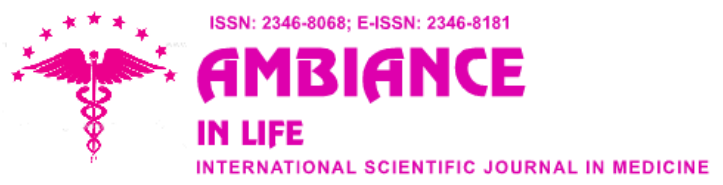

Введение: Нейробластома (НБ) - самая распространенная экстракраниальная опухоль детского возраста, развивающаяся из клеток-предшественников симпатической нервной. Данная опухоль составляет 7-8\% от всех злокачественных новообразований (ЗНО) детского возраста и является до 10-15\% причиной смерти у детей с $3 \mathrm{HO}$ [1].

Клинически НБ характеризуется высокой степенью гетерогенности: от спонтанного регресса до агрессивного течения, метастазирования и гибели пациента.

Цель: Оценить результаты терапии пациентов с диагнозом «нейробластома», получивших лечение в Научном центре педиатрии и детской хирургии (НЦПиДХ) согласно протоколу NB2004

Материалы и методы: Проанализированы 113 случаев впервые установленного диагноза «Нейробластома» в клинике НЦПиДХ с 2015 по ноябрь 2020 года: 57 мальчиков и 56 девочек. Медиана возраста на момент постановки диагноза составила 21,5 месяцев (от 0,8 до 191,8 месяцев). Преобладали пациенты старше 12 месяцев - 88,4 \%, дети до года -13 пациентов (11,6\%). По локализации опухоли: забрюшинное расположение опухоли отмечалось у 93 пациентов, в средостении у 12 пациентов; и в средостении, и забрюшинно - у 3 пациентов, в области шеи - у 3, в 2 случаях НБ без первичного очага. В 73,4\% случаев зафиксировано первично-диссеминированное течение НБ: наиболее часто выявлялось метастатическое поражение костного мозга, костей, лимфатических узлов. Согласно стадированию по INSS: 1 стадия выявлена у 17 пациентов (15\%), 2 стадия - у 5 (4,4\%), 3 стадия - 13 (11,5\%), 4 стадия71 (62,8\%), 4s -7 (6,3\%). В 22,1\% случаев выявлена амплификация гена N-MYC, 1p в 5,3\%. При стратификации на группы риска согласно протоколу NB-2004: к «observation group» отнесены 26 пациентов (23\%), группа промежуточного риска - 14 (12,4\%), группа высокого риска - 73 больных $(64,6 \%)$.

Анализ общей выживаемости (ОВ) и бессобытийной выживаемости (БСВ) выполнен методом Каплан-Майера в программе IBM SPSS Statistics.

Результаты: Медиана наблюдения за пациентами составила - 20,4 месяца (0,03 месяца-132,43 месяца). Общая 5-летняя выживаемость $(\mathrm{n}=113)$ составила - 61,9\%. 2-летняя БСВ - 35\%. В общей когорте пациентов прогрессия основного заболевания отмечалась в 24 случаях $(21,2 \%)$, рецидив НБ - у 18 пациентов (15,9\%).

ОВ в группе высокого риска - 43,8\%, в группе промежуточного риска - 85,7\%, в группе низкого риска - 100\%. 37 пациентам из группы высокого риска проведена ауто-ТГСК. ОВ в группе после ауто-ТГСК - 54,1\%. Медиана наблюдения после ауто-ТГСК - 12,47 месяцев (0,13 месяцев до 61,03 месяца).

Выводы: Терапия согласно протоколу NB-2004 является эффективной и показывает высокую OB в низкой и промежуточной группе риска. Результаты лечения пациентов в НЦПиДХ разных групп риска сопоставимы с международными данными (GPOH). Остается низким показатель ОВ в высокой группе риска - 43\%, что требует оптимизации диагностики, разработки новых подходов терапии пациентов данной группы.

\section{ЛИТЕРАТУРА}


1. Ferlay J, Ervik M, Lam F, Colombet M, Mery L, Piñeros M, Znaor A, Soerjomataram I, Bray F (2018). Global Cancer Observatory: Cancer Today. Lyon, France: International Agency for Research on Cancer. Available from: http://gco.iarc.fr/today/data/factsheets/cancers/7-Stomach-fact-sheet.pdf [accessed 10 April 2020]

2. McKinnonPJ, CaldecottKW. DNA strand break repair and human genetic disease. Annu Rev Genomics Hum Genet. 2007; 8:37-55.

3. Jeggo PA, Lobrich M. DNA double-strand breaks: their cellular and clinical impact? Oncogene. 2007; 26:7717-7719.

4. HakemR. DNA-damagerepair; thegood, thebad, andtheugly. EMBOJ. 2008; 27:589-605.

5. O'DriscollM, GenneryAR, SeidelJ, ConcannonP, JeggoPA. An overview of three new disorders associated with genetic instability: LIG4 syndrome, RS-SCID and ATR-Seckel syndrome. DNARepair (Amst). 2004; 3:1227-1235.

6. RogakouEP, BoonC, RedonC, BonnerWM. Megabase chromatin domains involved in DNA double-strand breaks in vivo. JCellBiol. 1999; 146:905-916).

7. Sedelnikova OA, Bonner WM. $\gamma \mathrm{H} 2 \mathrm{AX}$ in cancer cells: a potential biomarker for cancer diagnostics, prediction and recurrence. CellCycle. 2006; 5:2909-2913. 


\title{
ДВОЙНЫЕ РАЗРЫВЫ НИТЕЙ ДНКА И РАК ЖЕЛУДКА.
}

\author{
Анар Туляева, Гульмира Журабекова ${ }^{2}$, Ербол Бекмухамбетов ${ }^{1}$, Ерболат Изтлеуов ${ }^{1}$, \\ Айдана Таутанова ${ }^{3}$. \\ ${ }^{1}$ Отеление онкохирургии, Кафедра Онкологии, Западно-Казахстанский Медицинский Университет имени М. \\ Оспанова, Казахстан, Email:Dekart_85@mail.ru \\ ${ }^{2}$ Кафедра фундаментальной медицины Высшей медицинской школы. Казахский национальный университет \\ имени аль-Фараби. Казахстан. \\ ${ }^{3}$ Отделение научно-аналитической работы Западно-Казахстанский Медицинский Университет имени М. \\ Оспанова, Казахстан.
}

Актуальность: Рак желудка во всем мире занимает 4 место по заболеваемости и 2 место по смертности [1], что предостовляеть сабой одно из немаловажных социальных проблем общества.

РЖ это сложное заболевание, возникающее в результате взаимодействия факторов окружающей среды и хозяина, основными факторами, способствующими высокой смертности РЖ, включают его молчаливый характер течения, поздние клинические проявления и лежащую в основе биологическую и генетическую гетерогенность.

Учитывая молчаливый и агрессивный характер РЖ, зачастую пациенты обращаются за медицинской помощью в запушенных стадиях. Современная наука, имея возможность изучат основу молекулярной- генетической особенностей онкологической патологии требует поиск и внедрения новых персонифицированных методик диагностики и мониторинга при лечениях онкологических заболеваний.

Фосфорилирование гистона H2AX на остатках Серина IY с конечной точки Карбоксила (который производит уН2АХ) является чувствительным маркером для репарации двунитевых разрывов (ДР) ДНК. Двунитевые разрывы ДНК являются серьезным поражением, которое может инициировать геномную нестабильность, что в конечном итоге приводит к раку[2,3] Неудивительно, что клеточная геномная целостность тщательно контролируется процессами, которые обнаруживают и восстанавливают двунитевые разрывы, а также останавливают прогрессию клеточного цикла до завершения восстановления [4] Заболевания человека с дефектами этих процессов часто проявляют предрасположенность к раку [5]. Ключевой компонент в восстановлении ДНК протеин гистона Н2AX, который быстро становится фосфорилированным на остатках Серина IY от карбоксильной конечной точки (конечной точки Карбоксила) (Серина с- IY) для того чтобы сформировать уН2АХ на возникающих местах ДР. В течение 30 минут после образования ДР большое количество молекул уН $2 \mathrm{AX}$ образуется в хроматине вокруг места разрыва, образуя фокус, где накапливаются белки, участвующие в восстановление ДНК и накоплении ремоделировании хроматина[6] Эта амплификация (усиление) дает возможность обнаружить индивидуальное ДР с антителом к yH2AX.

Поскольку ДР способствуют как геномной нестабильности, так и лечению рака, мониторинг их образования в клетке путем обнаружения образования фокуса уН2АХ может быть чувствительным средством для мониторинга прогрессирования рака и лечения[7].

Цель исследования: Изучение разрыва двух нитевых цепочек днка методом уН2АХ на аппарате AKLIDES ${ }^{\circledR}$. 
Материалы и методы: Пилотный проект. Поперечное исследования случай контроль. Случайная выборка. Пациенты с верифицированным диагнозом РЖ (N24), в контрольную группу участники у которых отсутствует диагноз РЖ(N 22).Средней возраст пациентов с РЖ составил 56,04[52,50:59,58], В контрольной группе 56,21 [52,42:60]. Все пациенты в первые выявленные с патоморфологический подтвержденным диагнозом РЖ, любой стадией, еще не получившие лечение со стороны онкологического профиля. В контрольную группу вошли условно здоровые люди.

Исследование проводилось в период с июля 2018 года по декабря 2019 года в МЦ ЗКМУ имени Марата Оспанова.

Метод оценки репарации двунитевых разрывов ДНК в лимфоцитах крови, непрямым иммунофлюоросцентным анализом при помощи системы $\mathrm{gH} 2 \mathrm{AX}$ foci на аппарате AKLIDES $^{\circledR}$ (Germany/Medipan).

Переподготовку проводили по о методике: После получение крови в объема 9 мл, добавляем 6 мл фракционирующего средства (C) в пробирки для разбавления пробы пациента. Центрифугируем при КТ , 1200 г , 20 мин. Затем при помощи пипеткой эпиндорф 1000мкл осторожно снимаем белую полосу периферийных мононуклеарных клеток(PBMCs) и переносим в другую пробирку для разбавления проб. Разбавляем PBS буфером (B I) в соотношении 1:1 и осторожно взбалтываем 3-4 раза. Дальнейшем центрифугируем суспензию $\left(\mathrm{KT}, 300^{\mathrm{x}} \mathrm{g}, 10\right.$ мин).Осторожно удаляем жидкую фракцию вакуумным насосом и добавив 2 мл PBS (B I), центрифугировать суспензию (KT, 250 $\mathrm{g}, 10$ мин, максимальный тормоз).Дважды повторяем процедуру, затем для подсчета клеток приготовленную клеточную суспензию разбавляем буфером (B1) 1:10 в пробирке. Последующим разбавив клеточным красителем (J) в соотношении 1:1 производим подсчет клеток в 10мкл клеточной суспензии, в счетной к Для посева клеток 2,0*106 клеток/мл( заданное значение) рассчитывается необходимый объем клеточной суспензии. Далее необходимый для культивации посева клеток объем клеточной суспензии разбавляется PBSбуфером (BI) до требуемого общего объема в стеклянной чаше и перед каждым забором, для сохранности клеток, тщательно перемешивается вручную. 50 мкл клеточной суспензии наносятся на каждое место нанесения 6-луночного носителя. После фиксации 6-луночные носители объекта (A) промывают $3^{\mathrm{x}} 10$ мин в PBS буфере (BI) в красильной ванне на шейкере (150-300 об/мин). В дальнейшем для пермеабилизации клеток 6-луночный носитель объекта погружают в холодную красильную ванну с ледяным пермеабилизирующим раствором (D) на 5 мин при температуре $4^{\circ} \mathrm{C}$. Затем 6- луночные носители объекта промывають $3^{\mathrm{x}} 10$ мин в BSA/PBS буфере (BII/BI) в красильной ванне на шейкере (150-300 об/мин). В дальнейшем в каждую лунку добавляется раствор вторичных антител (E II) и держится защищенном от света месте 1 ч при комнатной температуре.В каждую лунку добавить по небольшой капле покрывного средства (G) и поместить сверху покровное стекло (Н) избегая образования воздушных пузырей. Последующим проанализировать - луночные носители объекта при помощи системы gH2AX foci на аппарате AKLIDES ${ }^{\circledR}$ 


\begin{tabular}{|c|c|c|c|c|c|c|c|c|c|c|}
\hline \multicolumn{11}{|c|}{$\begin{array}{l}\text { U критерий Манна-Уитни По переменным 2-х независимых групп. Отмеченные критерии значимы на } \\
\text { уровне р <,05000 }\end{array}$} \\
\hline & $\begin{array}{l}\text { Сум.p } \\
\text { анг - } \\
\text { ГрупII } \\
\text { a } 1\end{array}$ & $\begin{array}{l}\text { Сум. } \\
\text { ранг } \\
- \\
\text { Груп } \\
\text { па } 2 \\
\end{array}$ & $\mathbf{U}$ & $\mathbf{Z}$ & $\begin{array}{l}\text { р- } \\
\text { уров. }\end{array}$ & $\begin{array}{l}\text { Z - } \\
\text { скор } \\
\text { p. }\end{array}$ & $\begin{array}{l}\text { p- } \\
\text { уров. }\end{array}$ & $\begin{array}{l}\text { N - } \\
\text { Группа } \\
1\end{array}$ & $\begin{array}{l}\text { N - } \\
\text { Групा } \\
\text { a } 2\end{array}$ & $\begin{array}{l}\text { 2-х стор } \\
\text { точное p }\end{array}$ \\
\hline Nuclei dia & $\begin{array}{l}517,00 \\
00\end{array}$ & $\begin{array}{l}564,0 \\
000\end{array}$ & $\begin{array}{l}264,0 \\
000\end{array}$ & $\begin{array}{l}0,00 \\
000\end{array}$ & $\begin{array}{l}1,000 \\
000\end{array}$ & & & 22 & 24 & \\
\hline NucleiBGInt & $\begin{array}{l}538,00 \\
00\end{array}$ & $\begin{array}{l}543,0 \\
000\end{array}$ & $\begin{array}{l}243,0 \\
000\end{array}$ & $\begin{array}{l}0,45 \\
079\end{array}$ & $\begin{array}{l}0,652 \\
138\end{array}$ & $\begin{array}{l}0,451 \\
37\end{array}$ & $\begin{array}{l}0,651 \\
726\end{array}$ & 22 & 24 & 0,655148 \\
\hline $\begin{array}{l}\text { Nuclei with } \\
\text { foci }\end{array}$ & $\begin{array}{l}529,00 \\
00\end{array}$ & $\begin{array}{l}552,0 \\
000 \\
\end{array}$ & $\begin{array}{l}252,0 \\
000 \\
\end{array}$ & $\begin{array}{l}0,25 \\
288\end{array}$ & $\begin{array}{l}0,800 \\
357 \\
\end{array}$ & $\begin{array}{l}0,252 \\
93\end{array}$ & $\begin{array}{l}0,800 \\
321\end{array}$ & 22 & 24 & 0,802254 \\
\hline $\begin{array}{l}\text { Apoptotic } \\
\text { cells }\end{array}$ & $\begin{array}{l}477,00 \\
00\end{array}$ & $\begin{array}{l}604,0 \\
000\end{array}$ & $\begin{array}{l}224,0 \\
000\end{array}$ & $\begin{array}{l}- \\
0,86 \\
860\end{array}$ & $\begin{array}{l}0,385 \\
064\end{array}$ & $\begin{array}{l}- \\
0,868 \\
79 \\
\end{array}$ & $\begin{array}{l}0,384 \\
962\end{array}$ & 22 & 24 & 0,388630 \\
\hline Foci overall & $\begin{array}{l}628,00 \\
00\end{array}$ & $\begin{array}{l}453,0 \\
000\end{array}$ & $\begin{array}{l}153,0 \\
000\end{array}$ & $\begin{array}{l}2,42 \\
989\end{array}$ & $\begin{array}{l}0,015 \\
104\end{array}$ & $\begin{array}{l}2,431 \\
17\end{array}$ & $\begin{array}{l}0,015 \\
051\end{array}$ & 22 & 24 & 0,014086 \\
\hline Foci dia & $\begin{array}{l}424,00 \\
00\end{array}$ & $\begin{array}{l}657,0 \\
000\end{array}$ & $\begin{array}{l}171,0 \\
000\end{array}$ & $\begin{array}{l}- \\
2,03 \\
407\end{array}$ & $\begin{array}{l}0,041 \\
945\end{array}$ & $\begin{array}{l}- \\
2,393 \\
06\end{array}$ & $\begin{array}{l}0,016 \\
709\end{array}$ & 22 & 24 & 0,041138 \\
\hline FociInt mean & $\begin{array}{l}579,00 \\
00\end{array}$ & $\begin{array}{l}502,0 \\
000\end{array}$ & $\begin{array}{l}202,0 \\
000\end{array}$ & $\begin{array}{l}1,35 \\
238\end{array}$ & $\begin{array}{l}0,176 \\
254\end{array}$ & $\begin{array}{l}1,352 \\
84\end{array}$ & $\begin{array}{l}0,176 \\
107\end{array}$ & 22 & 24 & 0,177968 \\
\hline Cluster & $\begin{array}{l}610,50 \\
00\end{array}$ & $\begin{array}{l}470,5 \\
000\end{array}$ & $\begin{array}{l}170,5 \\
000\end{array}$ & $\begin{array}{l}2,04 \\
507\end{array}$ & $\begin{array}{l}0,040 \\
849 \\
\end{array}$ & $\begin{array}{l}2,045 \\
70\end{array}$ & $\begin{array}{l}0,040 \\
787 \\
\end{array}$ & 22 & 24 & 0,038936 \\
\hline Foci mean & $\begin{array}{l}460,00 \\
00\end{array}$ & $\begin{array}{l}621,0 \\
000\end{array}$ & $\begin{array}{l}207,0 \\
000\end{array}$ & $\begin{array}{l}- \\
1,24 \\
243\end{array}$ & $\begin{array}{l}0,214 \\
078\end{array}$ & $\begin{array}{l}- \\
1,242 \\
66\end{array}$ & $\begin{array}{l}0,213 \\
993\end{array}$ & 22 & 24 & 0,216330 \\
\hline $\begin{array}{l}\text { Foci mean } \\
+\mathrm{Cl}\end{array}$ & $\begin{array}{l}483,00 \\
00\end{array}$ & $\begin{array}{l}598,0 \\
000\end{array}$ & $\begin{array}{l}230,0 \\
000\end{array}$ & $\begin{array}{l}- \\
0,73 \\
666 \\
\end{array}$ & $\begin{array}{l}0,461 \\
327\end{array}$ & $\begin{array}{l}- \\
1,063 \\
64\end{array}$ & $\begin{array}{l}0,287 \\
493\end{array}$ & 22 & 24 & 0,464994 \\
\hline pos. cells & $\begin{array}{l}515,50 \\
00\end{array}$ & $\begin{array}{l}565,5 \\
000\end{array}$ & $\begin{array}{l}262,5 \\
000\end{array}$ & $\begin{array}{l}- \\
0,02 \\
199 \\
\end{array}$ & $\begin{array}{l}0,982 \\
456\end{array}$ & $\begin{array}{l}- \\
0,021 \\
99 \\
\end{array}$ & $\begin{array}{l}0,982 \\
452\end{array}$ & 22 & 24 & 0,973947 \\
\hline $\begin{array}{l}\text { Foci } \\
\text { mean+LowInt }\end{array}$ & $\begin{array}{l}509,50 \\
00\end{array}$ & $\begin{array}{l}571,5 \\
000\end{array}$ & $\begin{array}{l}256,5 \\
000\end{array}$ & $\begin{array}{l}- \\
0,15 \\
393\end{array}$ & $\begin{array}{l}0,877 \\
665\end{array}$ & $\begin{array}{l}- \\
0,153 \\
96\end{array}$ & $\begin{array}{l}0,877 \\
639\end{array}$ & 22 & 24 & 0,870278 \\
\hline $\begin{array}{l}\text { Foci } \\
\text { mean+LowInt } \\
+\mathrm{Cl} \\
\end{array}$ & $\begin{array}{l}548,00 \\
00\end{array}$ & $\begin{array}{l}533,0 \\
000\end{array}$ & $\begin{array}{l}233,0 \\
000\end{array}$ & $\begin{array}{l}0,67 \\
069\end{array}$ & $\begin{array}{l}0,502 \\
416\end{array}$ & $\begin{array}{l}0,672 \\
04\end{array}$ & $\begin{array}{l}0,501 \\
557\end{array}$ & 22 & 24 & 0,506040 \\
\hline $\begin{array}{l}\text { pos. cells } \\
\text { LowInt }\end{array}$ & $\begin{array}{l}521,00 \\
00\end{array}$ & $\begin{array}{l}560,0 \\
000\end{array}$ & $\begin{array}{l}260,0 \\
000\end{array}$ & $\begin{array}{l}0,07 \\
696\end{array}$ & $\begin{array}{l}0,938 \\
652 \\
\end{array}$ & $\begin{array}{l}0,076 \\
98\end{array}$ & $\begin{array}{l}0,938 \\
640 \\
\end{array}$ & 22 & 24 & 0,939257 \\
\hline
\end{tabular}

Технические трудности: При проведение переподготовки (занимающие 10-12часов) отмечалась пониженное количество клеток в лимфоцитах у пациентов с РЖ по сравнению с условно здоровых людей.

Дизайн и Протокол исследования были одобрены на заседании локальной биоэтической экспертной комиссии при ЗКМУ имени Марата Оспанова (Протокол №24 от 03.10.17) Для сравнения независимых двух групп, использовалась непараметрический U-критерий Манна-Уитни. Рассчитанные значения U-критерия Манна-Уитни сравнивались с 
критическими при заданном уровне значимости $\mathrm{p}<0.005$. Расчеты проводились в программе Statistica.10 (Dell Technologies, Round Rock, Texac, США), а также в программе SPSS.v.25.

Результаты и их обсуждение: Статистически значимые различия обнаружены у пациентов с рж в количестве разрывов двух цепочных разрывов ДНА ( $\mathrm{p}=0,01)$,причем, следует отметить диаметр разрывов различается у пациентов с раком желудка намного больше $(\mathrm{p}=0,04)$.Кластерная агрегация двунитевых разрывов дна имеет также различия $(\mathrm{p}=0,03)$. B остальных клеточных параметрах статистический значимые различия не выявлены.

На основании таблицы №1 можно сделать вывод о том, что различий по Количество ядер с очагами, апопоптических клетках, позитивно окрашенные foci клетоках практически не наблюдается.

Заключение: Двунитевые разрывы ДНК являются основной причиной геномной нестабильности что последующим вызывает процесс рака. Исследования двунитевых разрывов ДНК при помощи системы $\mathrm{gH} 2 \mathrm{AX}$ foci на аппарате AKLIDES $^{\circledR}$ требует дальнейшего углубленного изучения, так как определения степени индуциирования Двунитевых разрывов может помочь при мониторинге эффективности лечени против рака.
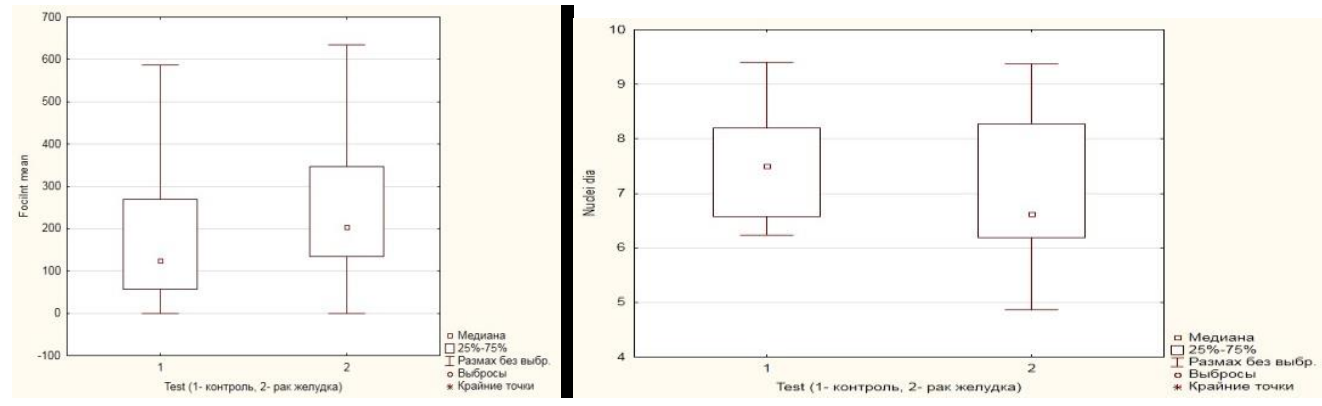

\section{График №1}

\section{ЛИТЕРАТУРА}

1. Ferlay J, Ervik M, Lam F, Colombet M, Mery L, Piñeros M, Znaor A, Soerjomataram I, Bray F (2018). Global Cancer Observatory: Cancer Today. Lyon, France: International Agency for Research on Cancer. Available from: http://gco.iarc.fr/today/data/factsheets/cancers/7Stomach-fact-sheet.pdf [accessed 10 April 2020]

2. McKinnonPJ, CaldecottKW. DNA strand break repair and human genetic disease. Annu Rev Genomics Hum Genet. 2007; 8:37-55.

3. Jeggo PA, Lobrich M. DNA double-strand breaks: their cellular and clinical impact? Oncogene. 2007; 26:7717-7719.

4. HakemR. DNA-damagerepair; thegood, thebad, andtheugly. EMBOJ. 2008; 27:589-605.

5. O'DriscollM, GenneryAR, SeidelJ, ConcannonP, JeggoPA. An overview of three new disorders associated with genetic instability: LIG4 syndrome, RS-SCID and ATR-Seckel syndrome. DNARepair (Amst). 2004; 3:1227-1235.

6. RogakouEP, BoonC, RedonC, BonnerWM. Megabase chromatin domains involved in DNA double-strand breaks in vivo. JCellBiol. 1999; 146:905-916). 
7. Sedelnikova OA, Bonner WM. $\gamma \mathrm{H} 2 \mathrm{AX}$ in cancer cells: a potential biomarker for cancer diagnostics, prediction and recurrence. CellCycle. 2006; 5:2909-2913. 


\section{EDITORIAL BOARD}

\section{Honorary Editors}

Davit Tophuria

Tbilisi State Medical University. Head of International Students Academic Department, Associate Professor. PhD in HNA.

Nigar Kamilova

AMU. Department of Obstetrics and Gynecology I. Doctor of Medical Sciences. Professor

Nino Didbaridze

Microbiology and Immunology Department. Immunologi Direction. Tbilisi State Medical University. PhD MD.

Nino Pirtskhelani

Associated Professor of Department of Molecular and Medical Genetics of Tbilisi State Medical University.

Rusudan Sujashvili

New Vision University. School of Medicine. Professor,

Saadat Sultanova

AMU. Department of Obstetrics and Gynecology I. Doctor of Medical Sciences. Professor.

Sabina Mashadiyeva

AMU. Department of Internal Medicine II. PhD in Medicine. Associate Professor.

Tamar Giorgadze

Tbilisi State Medical University. Department of Histology, Cytology and Embryology. Assistant Professor.

Tamar Didbaridze

Tbilisi State Medical University, First University Clinic. PhD in MD.

\section{International Advisory and Reviewer Team}

\section{Azerbaijan}

Aytekin Hasanova

Azerbaijan Medical University. I Preventive Medicine Faculty. Deputy of Dean. PhD in Medical Biology.

Araz Manucheri-Lalen

Associated Professor, PhD Department of Psychiatry, Azerbaijan Medical University.

Azer K. Mustafayev

Turan Medical Clinic. Cardiologist. PhD in Medicine. Azerbaijan.

Djamil Alakbarov

A researcher at the Research Institute for Lung Diseases. PhD in medicine. Azerbaijan

Elmira Aliyeva

Azerbaijan Medical University. Head of the Department of Obstetrics and Gynecology I. Doctor of Medical Sciences. Professor.

Gular Fataliyeva

Azerbaijan Medical University. Department of Internal Medicine II. PhD in Medicine. Associate Professor.

Irada Sultanova

Azerbaijan Medical University. Department of Obstetrics and Gynecology I. PhD in Medicine. Associate Professor.

Jamala Mursalova

Azerbaijan National Academy of Sciences. Genetic Resources Institute. PhD BS.

Leyla I. Djafarova

Clinic "Medium" Baku. Doctor of Medical Sciences. Professor

Mina Qarashova

Azerbaijan Medical University. Department of Obstetrics and Gynecology I. PhD in Medicine. Associate Professor.

Naila Quliyeva

Azerbaijan Medical University. Assistant in "Immunology" Program at Paediatrics Diseases Department. Docent and Academic Manager

in "Allergology and Immunology" Department.

Rashad G. Abishov

Dental Implant Aesthetic Center Harbor Hospital, Azerbaijan State Doctors Improvement Institute. PhD. Azerbaijan.

Saadat Safarova

Azerbaijan Medical University. Department of Obstetrics and Gynecology I. PhD in Medicine. Associate Professor.

Sain Safarova

Azerbaijan Medical University. Department of Internal Medicine II. PhD in Medicine. Associate Professor.

Sayyara Ibadullayeva

Institute of Botany. National Academy of Sciences. Professor. PhD in Biological Sciences.

Tariel Omarov

Azerbaijan Medical University. Department of surgical diseases. PhD in Medicine

Tubukhanum Gasimzadeh

Azerbaijan National Academy of Sciences. Institute of Dendrology of Azerbaijan NAS. Leading researcher PHD in Biological Sciences, Associate Professor. 


\section{IN LIFE}

\section{Georgia}

Eter Bukhnikashvili

Dental clinic "NGM-Innovation Dental". The doctor-stomatologist. PhD in Medicine.

Gulnara Kiliptari

Tbilisi StateMedical University. Head of ICU department. Associate professor.

lamze Taboridze

Scientific Center of the Humanitarian Educational University, Head, PhD in Medicine. Associate professor.

Maia Matoshvili

Tbilisi State Medical University. The First University Clinic. Dermato-Venereologist. Assistant Professor. PhD in DAPS.

Mariam Darbaidze

Davit Aghmashenebeli National Defense Academy of Georgia. The Head of Education Division. PhD in Biology.

Mariam Kharaishvili

Ilia State University. Asistent Professor. PhD MD.

Nino Gogokhia

Tbilisi State Medical University. Head of Laboratory the First University Clinic. Professor.

Nino Museridze

GGRC Georgian-German Center for Reproductive Medicine, Owner and Clinical Director. The Doctor of Medicine, Full Professor.

\section{India}

Prasanta Kumar Mitra

Sikkim Manipal Institute of Medical Sciences. Deptartment of Medical Biotechnology. PhD in Biochemistry.

\section{Kazakhstan}

Alessandra Clementi

Nazarbayev University School of Medicine. MD, GP. Assistant Professor of Medical Practice and Family Medicine

Anar Mirazagalieva

Astana Internationl University. Vice-President. PhD in Biology.

Gulmira Zhurabekova

Marat Ospanov West-Kazakhstan State Medical Academy. Department of Human Anatomy. Associate Professor

Marina Bobireva

West Kazakhstan State Medical University named Marat Ospanov. PhD

Nuriya Kharissova

State University of Karaganda. Associate Professor of Biological Science

Zhanargul Smailova

Head of the Department of Biochemistry and Chemical Disciplines named after MD, professor S.O. Tapbergenova NAC Medical University of city Semey.

\section{Libya}

Salaheddin Sharif

University of Benghazi, International Conference on Sports Medicine and Fitness, Libyan Football Federation- Benghazi PhD in Medicine (MD)

\section{Poland}

Robert Pawel Suslo

Wroclaw Medical University, Public Health Department, Health Sciences Faculty, Adjunct Professor of Gerontology Unit. PhD MD.

\section{Romania}

Minodora Dobreanu

University of Medicine, Pharmacy, Sciences and Technology of Târgu Mureș. Faculty of Medicine. Professor. PhD in Medicine.

\section{Russia}

Alexander A. Sazanov

Leningrad State University named A.S. Pushkin. Doctor of Biological Sciences. Professor

Grigory G. Levkin

Siberian State Automobile and Highway Academy. Omsk State Transport University. PHD of Veterinary Sciences

Nikolay N. Sentyabrev

Volgograd State Academy of Physical Culture. Doctor of Biological Sciences. Professor. Academician.

Olga Pavlova

Medical University named Rehabilitation, Doctors and Health, Professor of the Department of Morphology and Pathology, Doctor of biological sciences, physiology 
Sergei A. Ostroumov

Moscow State University. Doctor of Biological Science. Professor

\section{Serbia}

Jane Paunkovic

Faculty for Management, Megatrend University. Full Professor. PhD, Medicine

\section{Turkey}

Mehmet Inan

Turkish Physical Education Teachers Association. Vice president. PhD in Health Sciences, Physical Education and Sport Sciences

Muzaffer Sancl

University of Health Sciences. Tepecik Research and Teaching Hospital. Clinics of Gynecology and Obtetrics Department of Gynecologic Oncologic Surgery. Assocciated Proffesor.

Vugar Djafarov

Medical school at the University of Ondokuzmayıs Turkey. PhD. Turkey.

\section{Ukraine}

Alla Oleksyuk-Nexhames

Lviv University of Medicine. Neurologyst at pedagog, pryvaty refleksoterapy. MD PD.

Dmytro Horilyk

Head of the Council, at Pharmaceutical Education \& Research Center. PhD in Medicine.

Hanna Huliaieva

Institute of Microbiology and Virology, NASU, department of phytopatogenic bacteria. The senior research fellow, PhD in Biology.

Roman Lysyuk

Assistant Professor at Pharmacognosy and Botany Department at Danylo Halytsky Lviv National Medical University.

\section{USA}

Nicolai Panikov

Lecturer at Tufts University. Harvard School of Public Health. PhD/DSci, Microbiology

Rose Berkun

State University of New York at Buffalo. Assistant Professor of Anesthesiology, PhD. MD

Wael Al-Husami

Lahey Hospital \& Medical Center, Nardone Medical Associate, Alkhaldi Hospital, Medical Doctor, International Health, MD, FACC, FACP

\section{Uzbekistan}

Guzel Kutlieva

Institute of Microbiology. Senior Researcher. PhD in BS.

Khurshida Narbaeva

Institute of Microbiology, Academy of Sciences Republic of Uzbekistan, Doctor of biological sciences.

Shaklo Miralimova

Academy of Science. Institute of Microbiology. Doctor of Biology Sciences. PhD in BS. 


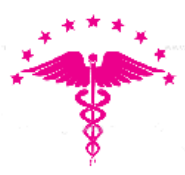

: 2346-8068; E-ISSN: 2346-8181

AMBIANCE

IN LIFE

INTERNATIONAL SCIENTIFIC JOURNAL IN MEDICINE

NGO International Center for Research, Education \& Training (Estonia, Tallinn) is publishing scientific papers of scientists on Website and in Referred Journals with subjects which are mentioned below:

(C) The Baltic Scientific Journals

ISSN: 2613-5817; E-ISSN: 2613-5825; UDC: 0 (0.034);

DOI PREFIX: 10.36962/PIRETC

Proceeding of The International Research Education \& Training Center.

http://sc-media.org/piretc/

ISSN: 2674-4562, E-ISSN: 2674-4597, UDC: 620.9 (051) (0.034);

DOI PREFIX: 10.36962/ENECO

Proceedings of Energy Economic Research Center. ENECO

http://sc-media.org/eneco/

ISSN: 1609-1620, E-ISSN: 2674-5224; UDC: 62 (051) (0.034);

DOI PREFIX: 10.36962/PAHTEI

Proceedings of Azerbaijan High Technical Educational Institutions. PAHTEI

http://sc-media.org/pahtei/

ISSN: 2663-8770, E-ISSN: 2733-2055; UDC:

DOI PREFIX: 10.36962/ETM

ETM Equipment, Technologies, Materials

http://sc-media.org/etm/

ISSN: 2733-2713; E-ISSN: 2733-2721; UDC:

DOI PREFIX: 10.36962/SWD

SOCIO WORLD-SOCIAL RESEARCH \& BEHAVIORAL SCIENCES

http://sc-media.org/swd/

Representation of the International Diaspora Center of Azerbaijan in Georgia. NGO. (Georgia Tbilisi) and Society of Azerbaijanis living in Georgia. NGO. (Georgia, Tbilisi) are publishing scientific papers of scientists on Website and in Referred Journals with subjects which are mentioned below:

\section{(C) Southern Caucasus Scientific Journals}

ISSN: 1987-6521, E-ISSN: 2346-7541; UDC: 551.46 (0510.4)

DOI PREFIX: 10.36962/GBSSJAR, IF-1.05

Gulustan-Black Sea Scientific Journal of Academic Research

http://sc-media.org/gulustan-bssjar/

ISSN: 2346-8068; E-ISSN: 2346-8181;

DOI PREFIX: 10.36962/ALISJMSC

Ambiance in Life-International Scientific Journal in Medicine of Southern Caucasus. http://sc-media.org/ambiance-in-life-isjmsc/

ISSN: 2298-0946, E-ISSN: 1987-6114; UDC: 3/k-144

DOI PREFIX: 10.36962/CESAJSC

The Caucasus-Economic and Social Analysis Journal of Southern Caucasus

http://sc-media.org/the-caucasus-sjarsc/ 
SALG NGO Southern Caucasus Scientific Journals.

\section{AIMS AND SCOPE}

SALG NGO Southern Caucasus Scientific Journals publishes peer-reviewed, original research and review articles in an open access format. Accepted articles span the full extent of the social and behavioral sciences and the humanities.

SALG NGO Southern Caucasus Scientific Journals seeks to be the world's premier open access outlet for academic research. As such, unlike traditional journals, SALG NGO Southern Caucasus Scientific Journals does not limit content due to page budgets or thematic significance. Rather, SALG NGO Southern Caucasus Scientific Journals evaluates the scientific and research methods of each article for validity and accepts articles solely on the basis of the research. Likewise, by not restricting papers to a narrow discipline, SALG NGO Southern Caucasus Scientific Journals facilitates the discovery of the connections between papers, whether within or between disciplines.

SALG NGO Southern Caucasus Scientific Journals offers authors quick review and decision times; a continuous-publication format; and global distribution for their research via SALG NGO Southern Caucasus Scientific Journals Online. All articles are professionally copyedited and typeset to ensure quality.

Those who should submit to SALG NGO Southern Caucasus Scientific Journals include:

Authors who want their articles to receive quality reviews and efficient production, ensuring the quickest publication time.

Authors who want their articles to receive free, broad, and global distribution on a powerful, highly discoverable publishing platform.

Authors who want their articles branded and marketed by a world-leading social science publisher.

Authors who want or need their articles to be open access because of university or government mandates.

ISSN: 1987-6521, E-ISSN: 2346-7541; UDC: 551.46 (0510.4)

DOI PREFIX: 10.36962/GBSSJAR

Gulustan-Black Sea Scientific Journal of Academic Research

http://sc-media.org/gulustan-bssjar/

ISSN: 2346-8068; E-ISSN: 2346-8181;

DOI PREFIX: 10.36962/ALISJMSC

Ambiance in Life-International Scientific Journal in Medicine of Southern Caucasus.

http://sc-media.org/ambiance-in-life-isjmsc/ 


\section{Crossref}

\section{zerodo}
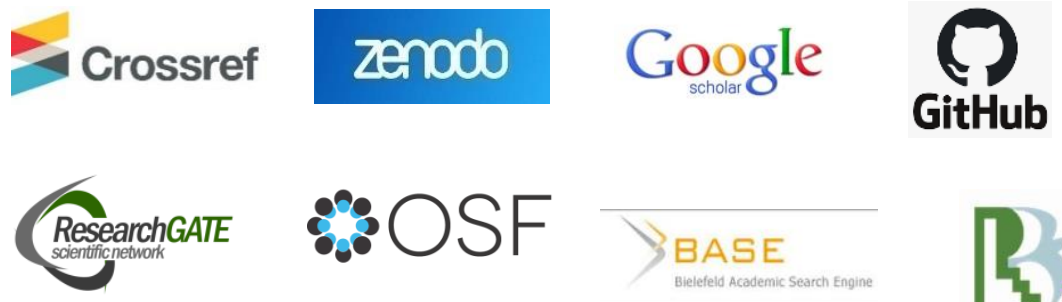

BASE
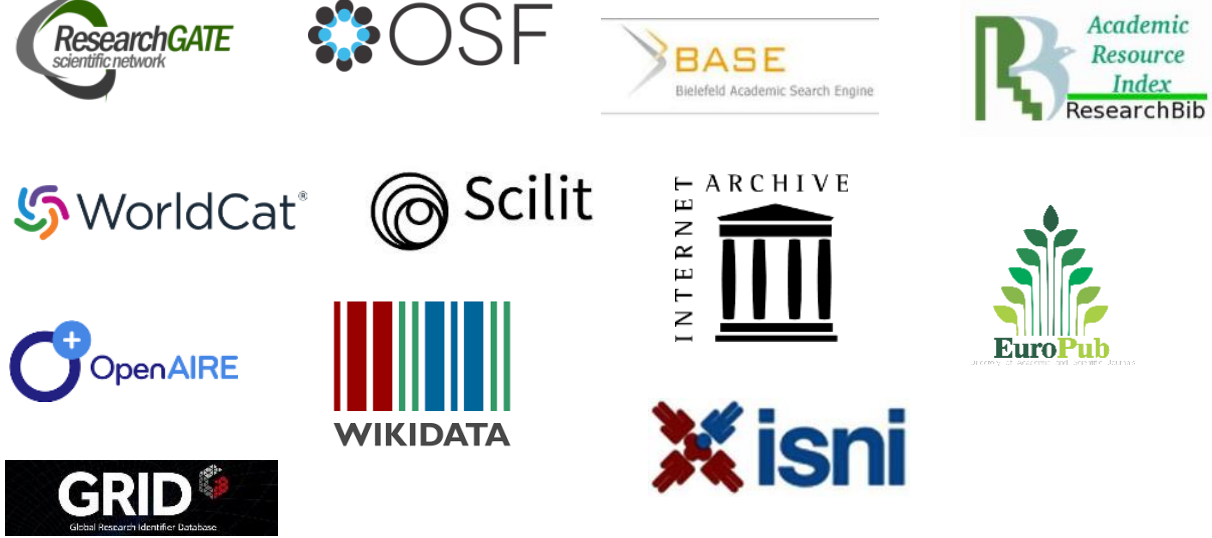

Kisni
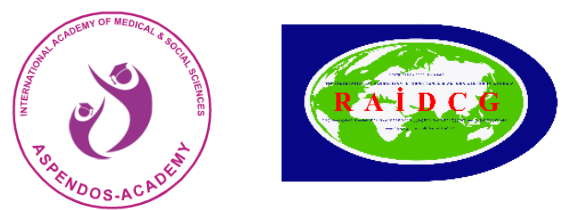

ISSN: 2346-8068; E-ISSN: 2346-8181; DOI: 10.36962/ALISJMSC

OPublisher: LTD Aspendos International Academy of Medical and Social Sciences. (UK, London).

Director and shareholder: Alexandra Cuco. Lawyer. Portugal.

Deputy and shareholder: Namig Isazade. PhD in Business Administration.

Direkotrun müavini və Payçı: Namig Isazade. PhD in Business Administration.

CEditorial office: 71-75 Shelton Street, Covent Garden, London, WC2H 9JQ, UK.

@Typography: LTD International Research, Education \& Training Center. (UK, London).

Registered address: 71-75 Shelton Street, Covent Garden, London, WC2H 9JQ, UK.

Telephones: +994 5524170 12; +994 518648894

Website: http://sc-media.org/

E-mail: gulustanbssjar@gmaill.com, sc.mediagroup2017@gmail.com

OPublisher: Society of Azerbaijanis living in Georgia. NGO. (Georgia, Tbilisi)

Deputy of director of organization: Seyfulla Isayev.

CEditorial office: Tbilisi, Georgia, 0163.

@Typography: NGO Representation of Azerbaijan International Diaspora Center in Georgia. SC Journals.

Registered address: Marneuli municipality, v. Takalo, Georgia, 0165.

Telephones: +994 5524170 12; +994518648894; +994 552417009

Website: http://sc-media.org/

E-mail: gulustanbssjar@gmaill.com, sc.mediagroup2017@gmail.com 
C SOUTHERN CAUCASUS SCIENTIFIC JOURNALS

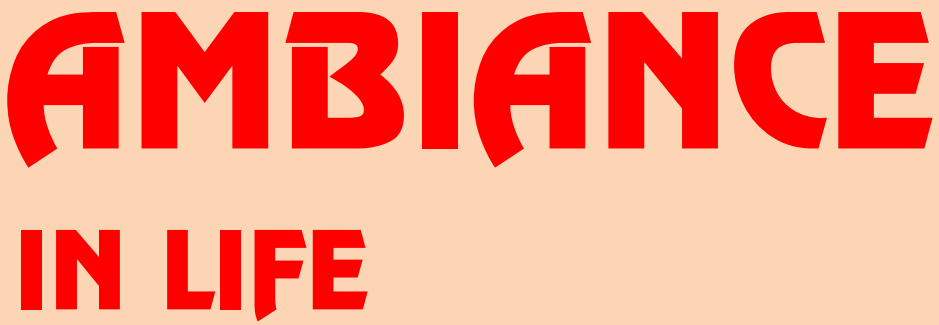

INTERNATIONAL SCIENTIFIC JOURNAL IN MEDICINE

JOURNAL OF BEHAVIORAL MEDICINE

REFEREED \& REVIEWED JOURNAL
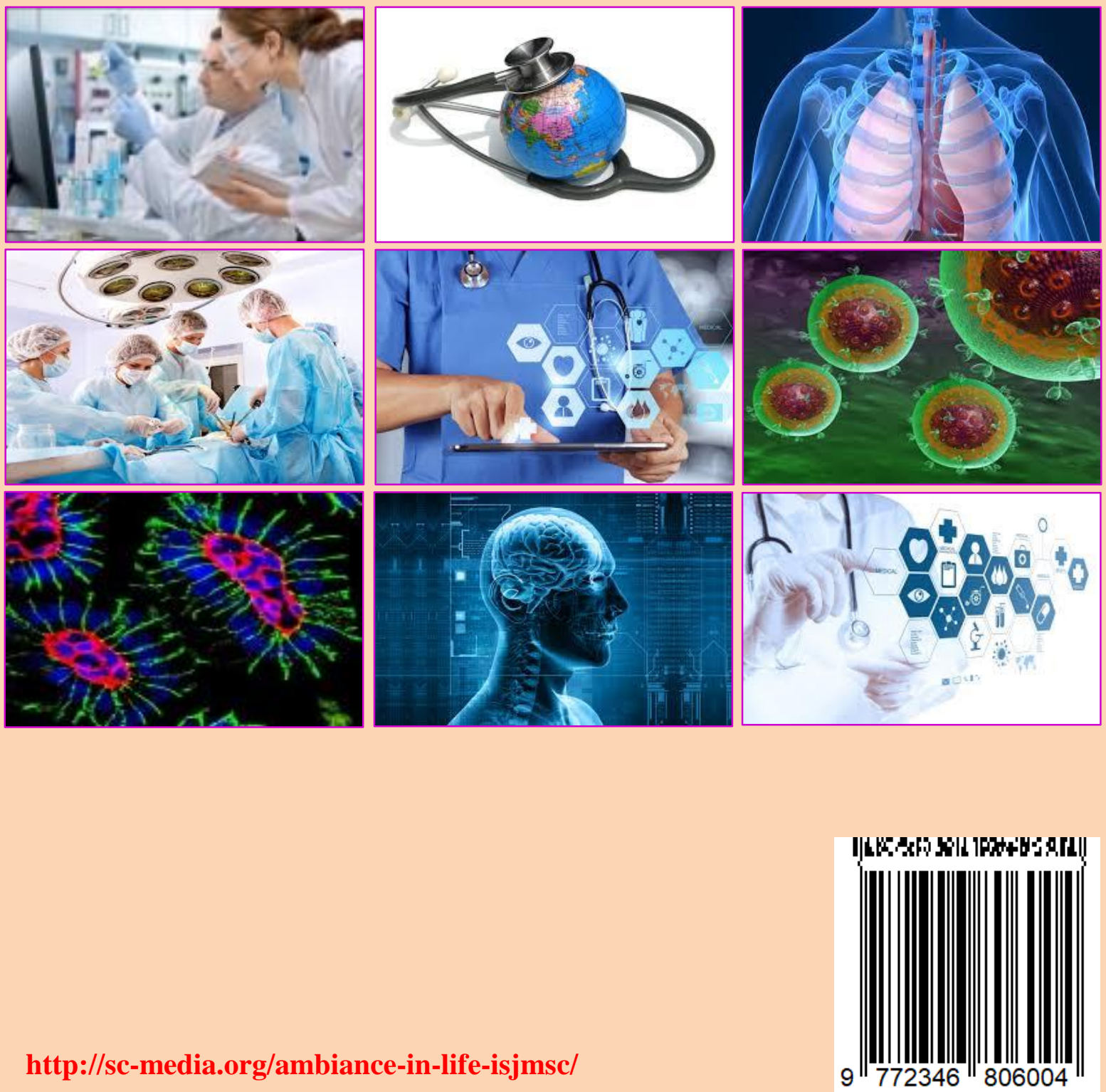